\title{
EXPLORING MOTIVATIONS FOR PARTICIPATION IN DIFFERENT MODES OF URBAN COMMUNITY ENERGY DEVELOPMENT IN ONTARIO, CANADA
}

\author{
By \\ Pallavi Roy \\ MASc. Environmental Applied Science and Management, Ryerson University, 2014 \\ MSc. Biological Sciences, BITS Pilani, India, 2010 \\ B. Eng. Chemical Engineering, BITS Pilani, India, 2010

\begin{abstract}
A dissertation
presented to Ryerson University

in partial fulfillment of the requirements for the

Doctor of Philosophy

in the program of

Environmental Applied Science and Management
\end{abstract} \\ Toronto, Ontario, Canada, 2019 \\ (C) Pallavi Roy, 2019
}




\section{Author's Declaration}

I hereby declare that I am the sole author of this dissertation. This is a true copy of the dissertation, including any required final revisions, as accepted by my examiners. I authorize Ryerson University to lend this dissertation to other institutions or individuals for the purpose of scholarly research. I further authorize Ryerson University to reproduce this dissertation by photocopying or by other means, in total or in part, at the request of other institutions or individuals for the purpose of scholarly research. I understand that my dissertation may be made electronically available to the public. 


\title{
Exploring Motivations for Participation in Different Modes of Urban Community Energy \\ Development In Ontario, Canada \\ Pallavi Roy \\ Doctor of Philosophy 2019 \\ Environmental Applied Science and Management, Ryerson University
}

\begin{abstract}
Urban energy systems are facing disruption at the same time as cities are increasingly focusing on sustainability. Community energy projects are increasingly gaining attention as systems that can deliver on the promise of sustainable growth and may even serve as a model for the future of energy planning, especially in an urban context. With the decreasing cost of modular generation technologies, it is increasingly feasible to generate local energy in urban areas. Not only is there potential for an economic benefit, but people are also empowered from being end of the line consumers to 'prosumers'. This paper explores the landscape for urban community energy projects with community involvement in ownership and management. Different models of ownership and management are examined and a spectrum of citizen participation in community energy is described. Various motivations for participation in community energy projects are identified. Interviews with representatives of key stakeholder groups were conducted to assess the theoretical foundation of the research and to refine a survey given to 270 residents of households located in the City of Toronto. The results were used to determine consumer/prosumer choices towards participation in local community generation and utilisation of renewable energy. This study shows that there is heterogeneity in the ways citizens can participate in community energy in an urban context. Relying on principal component factor analysis to identify the inferential variables associated with four motivating factors, namely Financial, Social Norms, Environmental and Community Concerns, and Trust in Technology, correlations with certain descriptive variables were examined. Stepwise multiple regression was used to identify respective models of causality between these motivating factors and three common models of community energy participation. The analysis shows that most residents in a Canadian urban centre prefer a more passive participatory role and that the financial factor remains the principle motivator. The results have implications for urban energy planning including the need for more utility and industry collaboration with urban community members.
\end{abstract}




\section{Acknowledgement}

This dissertation has taken close to four and a half years to complete. During that time, I have interacted with various other academics, power sector professionals and regular citizens who have helped shape my understanding of community energy and behavioural motivations for community engagement. I want to thank all those individuals who have been open to discussions and sharing their views on this topic with me. However, there are certain key individuals who I feel the need to mention especially. Foremost is my doctoral research supervisor, Dr. Phil Walsh, without whose guidance and support I would have never been able to shape my arguments, distill my thoughts and complete this dissertation. Not only has Dr. Walsh been a superb academic guide and helped me understand the academic rigour required to complete my $\mathrm{PhD}$, I have learnt so much more from him as it relates to understanding the energy sector, building and navigating networks, and developing my career in this sector. I thank him for his patience while I navigated through this journey and made mistakes and learnt my lessons.

I thank my doctoral dissertation committee for their careful consideration of my research and useful feedback.

I also acknowledge my husband, without whose support I would not have been able to dedicate days and months to my research. He helped create a stress-free environment for me so I could focus on my research. I would like to thank my parents for always believing in me and instilling in me the confidence to go forth and conquer the world. I want to thank my mother-in-law for her support and encouragement. Finally, I would like to thank my dog, for not eating my homework. 


\section{Table of Contents}

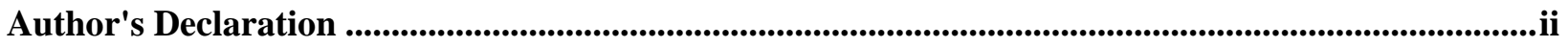

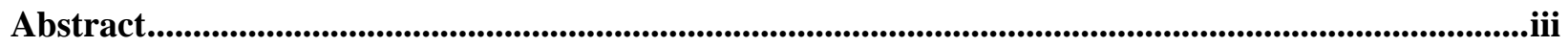

Acknowledgement ................................................................................................................................................................iv

Table of Figures....................................................................................................................................................... vi

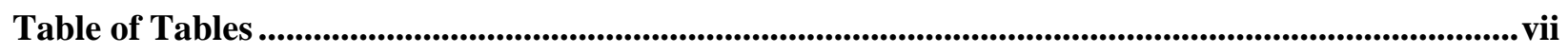

1. Introduction ................................................................................................................................................... 1

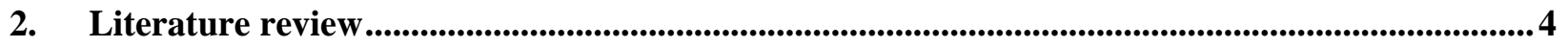

2.1 Collaborative socio-economic paradigm ............................................................................................4

2.2 Citizen empowerment in decision-making........................................................................................6

2.3 Community Energy

2.4 Spectrum of participation in community energy ............................................................. 16

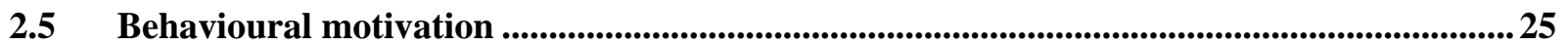

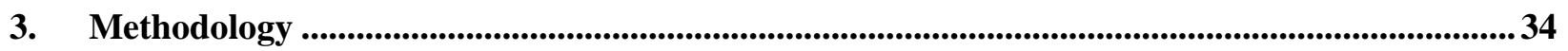

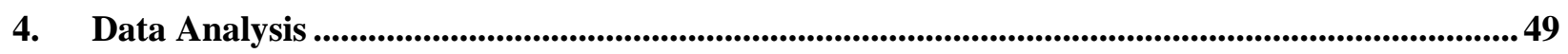

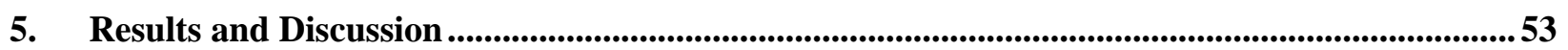

5.1 Financial and Security of Supply Factor .............................................................................. 67

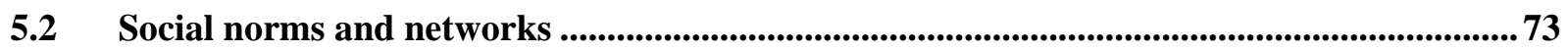

$5.3 \quad$ Environmental awareness and community concern ................................................................... 77

5.4 Uncertainty and trust in new technology ...................................................................................... 81

5.5 Summary by Participation Model .................................................................................................. 84

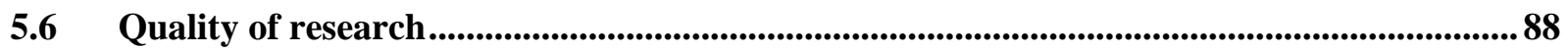

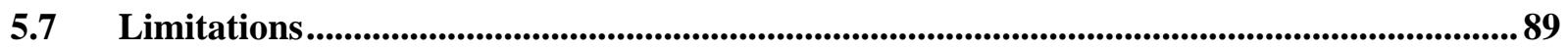

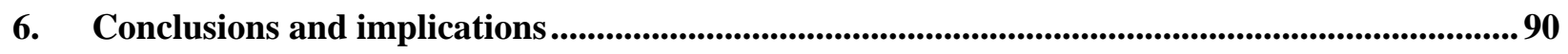

Appendix A: Test of Normality Results ..........................................................................................................99

Appendix B: Semi-structured Interviews Highlights........................................................................................ 119

Appendix C: Questionnaire ............................................................................................................................ 122

Appendix D: Regression Coefficients........................................................................................................... 128

References................................................................................................................................................................................... 137 


\section{Table of Figures}

Figure 2.1 - Arnstein's ladder of citizen participation (1969) ................................................... 6

Figure 2.2 - Spectrum of citizen participation in community energy ……………………......... 17

Figure 3.1 - Traditional mono-method research design and sequential mixed-method research design comparisons (Teddlie \& Tashakkori, 2006, p 16, p 22) ……………………................... 37

Figure 3.2 - Sequential Mixed-Methods Research Design ........................................................ 39

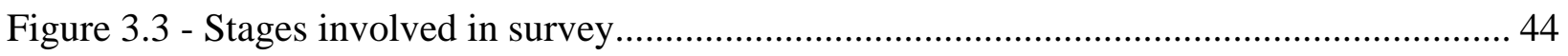

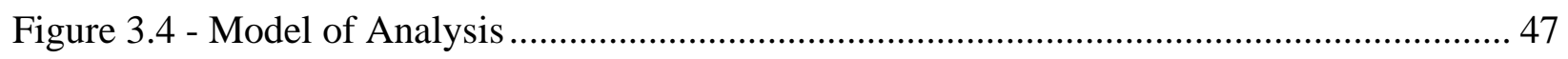

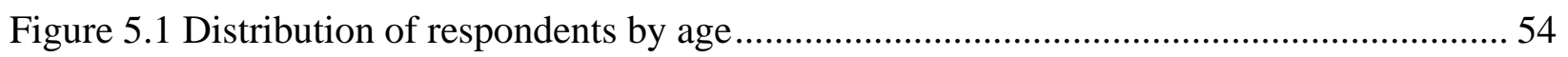

Figure 5.2 Distribution of respondents by ownership versus rental ........................................... 55

Figure 5.3 Distribution of respondents by their level of care for the environment .......................56

Figure 5.4 Participation preference data from Toronto ………………………….................... 57

Figure 5.5 Distribution of responses to more expensive community renewable energy project.. 58

Figure 5.6 Responses to investment for security of supply issues................................................59

Figure 5.7 Scree plot for principal factor analysis ................................................................... 65

Figure 5.8 Conceptual model of motivational factors and modes of citizen participation through

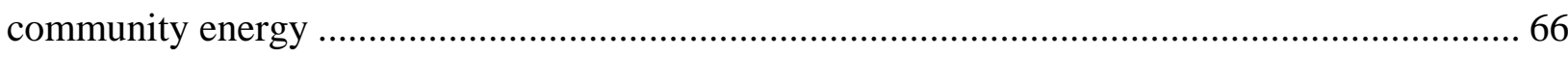

Figure 5.9 Financial factors and models of participation ......................................................... 69

Figure 5.10 Social norms and community energy participation ................................................. 74

Figure 5.11 Environmental factors and participation models ....................................................... 77

Figure 5.12 Trust in technology and participation models ........................................................ 81

Figure 5.13 Motivations for community led and managed projects ............................................. 84 
Figure 5.14 Motivations for participation in projects created in partnership with a third party organization 85

Figure 5.15 Motivations for participation in community direct investment of community energy projects 86

Figure 5.16 - Updated Conceptual Model......................................................................... 87

\section{Table of Tables}

Table 2.1 - Examples of different community owned projects........................................... 19

Table 2.2 - Motivations for participation in community energy projects (after Dóci and

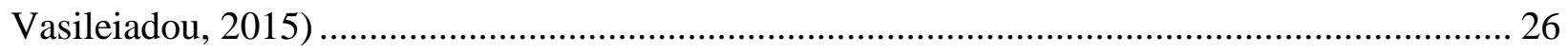

Table 3.1 Interview questions and subsequent use in current research ................................... 42

Table 3.2 List of descriptive and inferential variables......................................................... 48

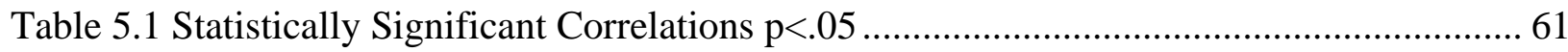

Table 5.2 Statistically Significant Correlations $\mathrm{p}<.05$ (Continued) .........................................62

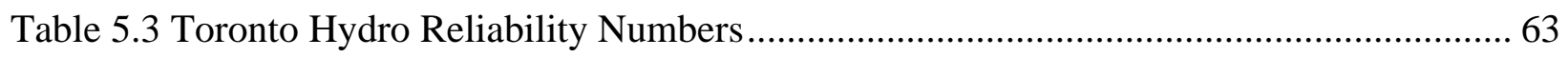

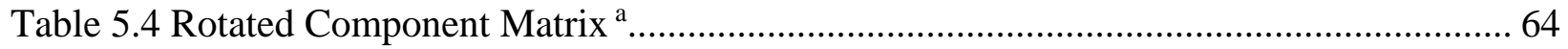

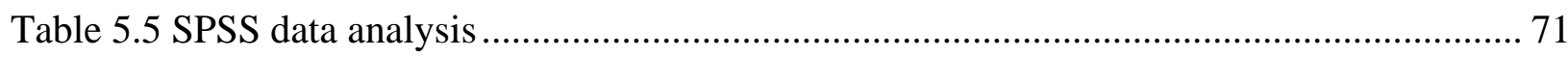

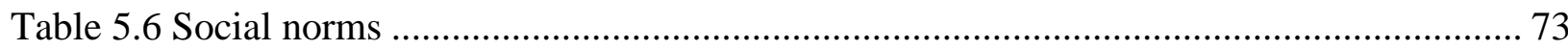

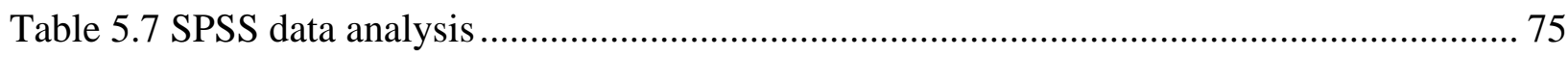

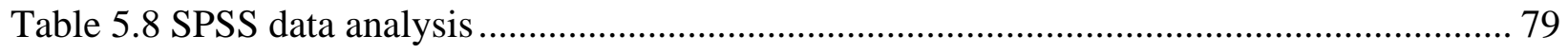

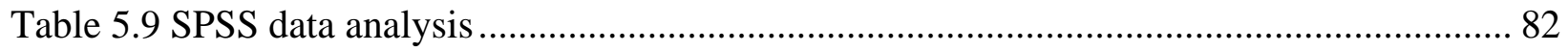

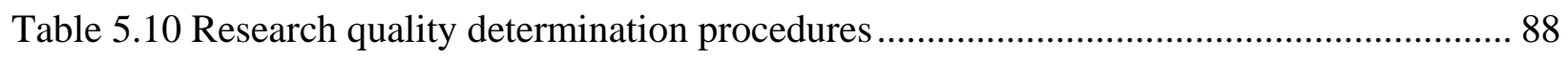




\section{Introduction}

Current economic systems and business models are increasingly failing at many important aspects such as inclusion, continued prosperity, development with a triple bottom line focus, and resilience to change as the human population grows (Goossens \& Mäkipää, 2007; Porter \& Kramer, 2011). For a sustainable future, we need to alter how we live. Since the economy drives the demand and use of resources, we need to change how we do business. A collaborative approach is gaining popularity and aims to build value through non-traditional and innovative business models. These business models are increasingly focused on increasing citizen participation and building-in social as well as economic and environmental benefits as part of the business model.

The collaborative socio-economic model is more sustainable than the one in place now that is based on traditional owner-consumer relationships (Heinrichs, 2013). The collaborative economy is described as a rapidly growing movement of social innovations aimed at collaboration and sharing as a way of building communities (Matofska, 2014; Schor, 2016). Collaborative models of consumption, creation, and marketplace creation are present throughout the value chain, e.g. co-operatives, libraries, community spaces. The collaborative economy can manifest in almost every area of society and corner of the earth and can have immense potential for revolutionising the energy sector.

Energy is one of the most critical resources in the economic development of nation states. Humans have been forever looking for more efficient ways of extracting energy from resources. The availability of surplus energy has been directly linked with the development of humans as a society (Rosa et al., 1988). An affordable and assured supply of energy is required for industrial development and the progress of communities. However, greenhouse gas emission concerns 
combined with rising pollution concerns due to the use of conventional fossil fuels are leading to increased attention to renewable sources of energy.

Cities, the drivers of economic growth, are also significant consumers of energy. This is true for Canada where real estate, services sector, finance and banking are among the top five industries contributing to the Canadian GDP and growth (Statistics Canada, 2019a). As most of these businesses are centred in major urban centres of Canada, urban areas are the fastest growing and large contributors to Canada's growth.

Urban regions of the world hold over half the population of the earth and account for two-thirds of the primary energy demand (International Energy Agency [IEA], 2016). Almost none of this energy is produced anywhere in or near the city. With technological advancement, there is considerable potential for renewable generation within cities to meet some of this massive urban energy demand. As the price of modular and small-scale energy technologies fall, urban renewable energy options have increasingly become cost competitive with traditional sources such as centrally- generated electricity, natural gas, coal and diesel. According to the IEA (2016), buildings in urban areas can provide space for local generation utilising photovoltaic (PV) arrays in that, 'The technical potential for rooftop solar PV could provide up to $32 \%$ of urban electricity demand" (p. 8). However, this sector is in a nascent stage and needs a further push for wide-scale adoption in urban environments.

Community energy projects have had different methods of collaborative ownership, from people collectively owning a few solar PV panels to a solar farm managed by a large developer to the community managing different systems of sharing, of conventional financing and management between multiple stakeholders (Stamford 2004; Walker, 2008; Wizelius, 2014). These examples are found mostly in studies from the western and northern European countries of Germany, 
Denmark, Scotland, and The Netherlands and so on (Gipe, 1996, Monaghan 2016). Therefore, given the geographical context of this research, it is essential to understand and pursue the methods most suitable to the Ontario urban energy landscape.

The current research examines, from a Toronto perspective, how the collaborative socio-economic paradigm can influence the urban energy sector leading to greater adoption of renewable energy technology. The researcher further investigates community energy as a form of collaborative economic practice in the energy sector. The study goes on to present and discuss a spectrum of community energy with various levels of citizen participation. A comprehensive literature review was undertaken to identify questions to be asked in stakeholder interviews and for a survey questionnaire provided to residents of Toronto. This questionnaire solicited motivational information and preferences as they relate to participation in local community energy projects. The data were analysed using SPSS and statistical methods such as principal factor analysis, and multivariate regression were used. A new conceptual model was presented because of the findings of this study. The next five sections detail the literature on the topic, the methodology and methods used for the current study, data analysis conducted, results and discussion and, finally, the conclusion. 


\section{Literature review}

\subsection{Collaborative socio-economic paradigm}

As unlimited growth becomes more elusive in a limited resource economy, there is a need to look beyond traditional business models. While there is widespread recognition of the unsustainable nature of the consumptive economic model in a world of finite resources (Stiglitz et al., 2009; Dietz \& O’Neill, 2013), there remains an appreciation of the interwoven nature of our lifestyles choices, economics, social behaviours and the environment (Røpke, 2009; Spaargaren \& Van Vilet, 2000). Multitudes of factors exist that drive our choices for consumption, such as economic, political, and social structures, as well as behavioural factors based on values and aspirations.

Thus, there is a strong and immediate need to redefine our current socio-economic paradigms and our everyday lifestyle choices. Many theories have been suggested to solve this conundrum and to adopt a more sustainable path to resource utilisation (Ackerman, 1997; Seyfang, 2009; Jackson \& Senker, 2011).

The concept of the collaborative economy and its definition are at present being discussed and developed (Owyang et al., 2013). The definitions are not yet concrete. This uncertainty is reflected by the other similar terms which are often used to describe concepts such as, collaborative consumption, the sharing economy, etc. (Botsman, 2013, Kostakis \& Bauwens, 2014). In the present study, the term collaborative economy will be used. The term is used to denote any practices that refer to collaborative models of utilisation of resources (physical or abstract) through different methods such as sharing, swapping, trading, among others (Botsman \& Roger, 2010). A collaborative socio-economic paradigm changes how we consume and produce goods, and reinvents social and economic thinking by prioritising access over ownership. Different studies have tried to categorise the activities that fall under the collaborative socio-economic practices 
umbrella, and two broad categories have been identified; that of shared services, and shared products (Schor, 2016; Botsman \& Roger, 2010). Recent studies have shown that there is an immense space for the collaborative economy to flourish as a way to save resources while creating new business models and promoting job creation (Stokes et al., 2014). The shared economy resonates with the spirit of the generation, and the needs for a sustainable future.

The primary drivers of this trend are:

1. Technological advancements;

2. Increasing interest in socially and economically viable sustainable practices.

What is at play in the collaborative economy goes beyond the rational choice theory of economics. Aside from these tangible benefits, the collaborative economy is part of a larger paradigm shift, which aims to create new value: a value derived from the importance given to the environment and local economies while looking beyond the bottom line. The collaborative economy enables local entrepreneurship and local economic investment because transactions can be valued locally, benefits felt locally, thus, holding potential for how the future of business evolves (Schor, 2016). The collaborative economy has potential to transform the electricity and energy sectors by empowering people to be producers and decision makers. A suitable model to further understand the connection between empowerment and the collaborative economy is Arnstein's ladder of citizenship power proposed in 1969. This ladder of participation as seen in Figure 1 differentiates succeeding rungs of citizen participation; evolving from manipulation to citizen control. 


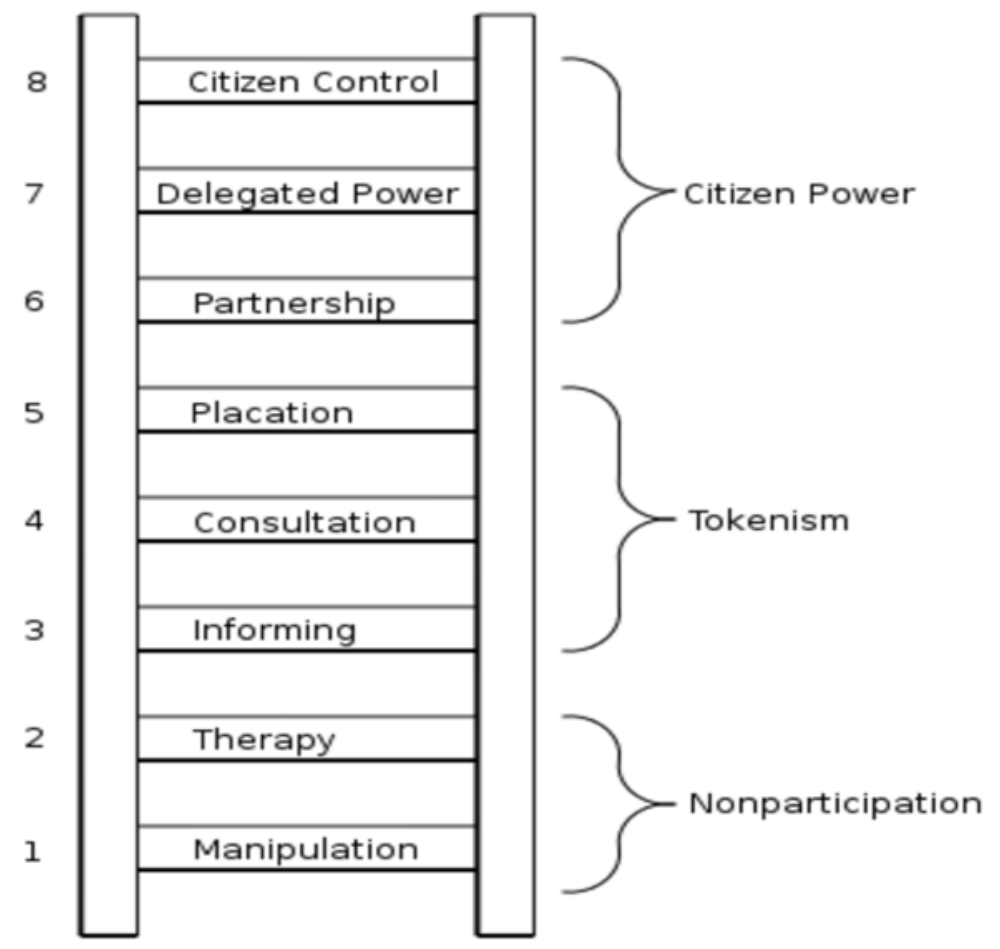

Figure 2.1 - Arnstein's ladder of citizen participation (1969)

The collaborative economy empowers people to take greater charge of their consumption, not only by being more involved but also by being producers, thus enabling them to create value and to share it with others.

\subsection{Citizen empowerment in decision-making}

The landscape of public decision-making is slowly evolving from a focus on decisions made by state officials and experts only, to addressing stakeholders' interests and engaging citizens (Bijlsma et al., 1988; Savan et al., 2004). There is a growing movement demanding a shift from the regular system of government to one of governance (Hoffman \& High-Pippert, 2010; Corscadden et al., 2012). This change has been especially prominent in environmental decision making, with the advent of environmental assessments involving a public consultation component. Public participation has been defined as "the practice of involving residents in the agenda setting, 
decision-making, and policy-forming activities of organisations/ institutions responsible for policy development" by Rowe \& Frewer (2005, p. 253). However, the range of involvement could be very broad, from awareness building and consultation to collaboration (Arnstein, 1969). The benefits include:

- Better decision-making: It is gradually being accepted that meaningful public engagement leads to better decisions (City of Edmonton, 2015). Often people in a community are a better judge of the issues at hand and can provide suggestions for implementations. It is also seen to increase trust and credibility in decisions when they are made collaboratively or in consultation with the public.

- Social license: "Social license generally refers to a local community's acceptance or approval of a company's project or ongoing presence in an area. It is increasingly recognized by various stakeholders and communities as a prerequisite to development" (Yates \& Horvath, 2013, p. 1). Be it oil, coal, nuclear or renewables, energy projects often face a lot of opposition from local communities. Proper community engagement, along with transparency and openness becomes particularly important in such scenarios. Warren \& McFayden (2010, p. 204) describe the positive effects of community ownership on public acceptance of wind turbines, "The data also indicate that local attitudes could become even more positive if future windfarms were owned by local communities. The fact that the residents of Gigha have affectionately dubbed their turbines 'the Three Dancing Ladies' is indicative of the positive psychological effects of community ownership. These results support the contention that a change of development model towards community ownership could have a positive effect on public attitudes towards windfarm developments in Scotland." 
Arnstein said in her 1969 paper, Ladders of Citizen Power "citizen participation is citizen power" (p. 217). The Arnstein paper went on to describe a scale of citizen participation. As stated in the article, "the eight-rung ladder is a simplification, but it helps to illustrate the point that so many have missed - that there are significant gradations of citizen participation. Knowing these gradations makes it possible to cut through the hyperbole to understand the increasingly strident demands for participation from the have-nots as well as the gamut of confusing responses from the powerholders." (p. 217). What this describes is a fundamental idea that the citizens need to have a say in decision-making that affects them, to avoid future chaos and anarchy.

Community renewable energy is an idea that can bring together different aspects discussed above regarding citizen power, integration of renewable technologies, ensuring energy security as well as prosperity for communities (Hoffman \& High-Pippert, 2005; Jami \& Walsh, 2014). Community energy projects with their "bottom-up" approach are effective in bringing the public voice into energy policy making. Focussing on community involvement in renewable energy projects is an important way of assuring continued prosperity for communities in developed nations like Canada. Community energy projects can be a way of reviving communities, in urban or rural areas and also in remote locations such as isolated First Nations reserves but especially in urban areas where diffusion of local generation has been low (Michelsen \& Madlener, 2012). The traditional system of energy production, transmission and distribution is well established and involves highly centralised energy infrastructures and top-down policy making with end-of-the-line dependent consumers having no say in the process (Roy, 2014). Hence, a community energy project that has locally and cooperatively-owned facilities for power generation or home heating can be a novel model of energy provision and distribution in urban areas. This empowers community members to become producers and not just traditional consumers. With the likelihood of selling electricity, 
back to the grid as independent power producers, collaboratively owned community energy projects are becoming liberated, democratised market actors in their right (Oteman et al., 2014). As Coleman and Gotze have concluded in their paper, "The alternative to engaging the public will not be an unengaged public, but a public with its own agenda and an understandable hostility to decision-making processes which appear to ignore them. By bringing citizens into the loop of governance, opportunities for mutual learning occur: representatives can tap into the experiences and expertise of the public and citizens can come to understand the complexities and dilemmas of policy-making" (2001, p. 12). Not engaging the public may be the simplest option, but it can have potential consequences when the public opposes proposed developments and disrupts plans, causes delays and leads to millions in lost revenue.

The literature tells us that land use planning is one of the barriers to renewable energy development, especially contested planning decisions in the onshore wind industry in many communities (Loring, 2007). Public participation in the planning process is increasingly being encouraged and considered an essential component of effective decision-making. In Ontario, and Canada, public consultations have become mandatory for the approval of renewable energy projects. Loring's (2007) study focuses on investigating the relationships among issues of public participation, public acceptance, network stability and planning success as their variables. DevinWright et al., (2001) explored local community involvement in wind planning in the UK and suggested that social and psychological dynamics were important factors related to wind energy development success. Hence, community energy provides us with a framework of energy generation systems that further enhances the decision-making capability of community members, where they can be empowered to not only make decisions but also manage and invest in the projects. 


\subsection{Community Energy}

At the outset, there are certain terms, which need further defining, to set a baseline of understanding and assumptions. The term 'community energy' has been defined in various ways by various researchers and practitioners. According to Hoffman \& High-Pippert (2010, p. 7569) "As such, a "community energy initiative" can be characterized by the degree of community participation in the creation of an initiative; the manner of governance subsequent to its creation; whether or not locally generated energy is consumed locally, the structure of ownership; or by the technology employed in such a system."

According to the Toronto Renewable Energy Cooperative, the term 'community power' is described as referring to "the direct participation in, ownership of, and sharing of collective benefits from renewable energy projects, by and for a local community Projects may be owned inpart or in-full by co-operatives, First Nations, Métis communities, charities and non-profits, other community groups and/or municipal entities, including schools, health centres, etc. It's a democratic ownership process where local groups are investing in their own communities and using the returns to support their local economy: a win-win-win for the community, individual investors and the province."

As society becomes more connected through technological innovation, the scope of what defines a community has transcended physical realities. For the purposes of the current study, the phrase local community energy systems will be used, to denote local energy systems, which involve the local community through investment, ownership and management. With local community energy projects, the idea is to create sustainable energy systems and improving economic, social and

\footnotetext{
${ }^{1}$ https://www.trec.on.ca/community-power/
} 
environmental conditions. These objectives can be achieved by involving more people in the sharing of costs and benefits by empowering them to be involved from an early point in projects. Projects that do involve community ownership-through financial investment or managerial control by or on behalf of groups of 'members of the public'-have achieved this to different degrees and in different ways, mostly in the developed areas of the world (Stamford 2004; Walker, 2008, Moss et al., 2015).

Community energy challenges conventional business and technological paradigms in the following ways:

- Moving production closer to consumption centres

- Empowering the consumer to be a producer as well, thus creating more integrated power markets

- Internalising externalities such as social impacts of energy production

- Moving from a centralized model to a decentralised model of power production and decision making.

Advantages of community energy projects include economic, social and environmental benefits (Lovins, 1977; Hoffman \& High-Pippert, 2005; Jami and Walsh, 2014; Walker et al., 2014) such as:

- $\quad$ New sources of capital in the local economy

- Increased public support for the project

- Energy costs that are locally spent, strengthening the local economy and creating jobs. 
McHarg (2015, p. 299) lists three ways in which community energy has been transformative in Scotland:

"First, it provides levels of financial benefit which may transform local economies, and hence community sustainability, particularly in remote or disadvantaged areas; community-owned renewable generation quite literally empowers communities, both economically and socially. Second, community ownership can be transformative because of the way it opens up broader questions about the distribution of power and resources in society. This is most apparent in Scotland in the relationship between renewable energy and a wider process of land reform, which is currently ongoing. Finally, community ownership may be transformative of the energy industry itself: some see it as the harbinger of a new model of 'energy democracy' which may challenge the prevailing neo-liberal paradigm”.

The benefits to community from community energy projects can be felt through good jobs for the community, more engaged citizens and so on, creating an imperative for governments to support them. Not only are there larger societal benefits, using community energy for local generation can help reduce costs in the long run, if community energy is used to better manage peak loads, deferring new large builds, and possibly reducing grid electricity prices. The benefits of community participation are being recognised by governments in Canada, where provincial procurement programs have sought certain amounts of community participation and community financing for project approval (Alberta, 2016; LTEP 2017). Community energy projects empower participants to not just be consumers but also become prosumers, by generating their own energy and even selling to the grid or others. Urban communities also have the potential to generate local energy, meeting their own demand. Thus, it is important that we focus on the conditions under which community participation in urban community energy projects could flourish. Bauwens et al., (2016) identify the following factors as enabling community energy projects: 
- $\quad$ Government system variables which include the different support mechanisms for renewables such as Feed-in-tariff schemes, subsidies etc.

- Actor variables, which include, attitudes toward community energy projects and a culture of local energy activism.

Government support is very important in supporting community energy projects. Western European countries such as Germany, The Netherlands, Denmark, Scotland, Sweden and others provide support to different methods of local and clean generation through subsidies, tax waivers and other instruments (Bolinger, 2001; Bauwens et al., 2016). Scotland is one of the few countries that has a specific target for community and locally owned energy. They aimed to have $500 \mathrm{MW}$ of capacity by 2020, but managed to achieve it five years early, estimating 508 MW in 2015 (Government of Scotland, 2015; McHarg, 2015). In Germany, the installed renewable energy consumption is around $170 \mathrm{TWh}$, amounting to about $30 \%$ of the net consumption of electricity (International Energy Agency [IEA], 2017). This high value can be attributed to about 772 energy co-operatives that function in Germany (German Cooperative and Raiffeisen Confederation, 2015). Almost half (46\%) of the installed renewable energy capacity in Germany is owned by private individuals and farmers (German Federal Ministry for Economic Affairs and Energy, 2015). Yildiz's (2014) study talks about the challenges of financing renewable energy projects and suggests that cooperatives can be a useful model of business, raising capital from private individuals to finance "tough-to-finance" renewable energy projects. The study finds that in Germany "private individuals contribute significantly to renewable energy finance" (p. 677). The research further identifies that cooperatives and closed-end funds are important business models for increasing private finance in renewable energy projects. 
The installed renewable capacity is even higher for Denmark with $43 \%$ of energy needs from renewables, especially wind. In Denmark over 100 co-operatives make up about $30 \%$ of the total wind installed capacity. Denmark is one of the leaders in renewable energy, managing to provide one third of their demand through wind energy (Meyer, 2007). The process to include large-scale renewables in the energy mix is a result of careful planning and support from the government. The municipally owned electricity distributors in Ontario manage their long-term energy planning, with an overarching mandate to provide societal benefit. Denmark's electricity market is not vertically integrated"-meaning that different operators, similar to the electricity system in Ontario, oversee generation, transmission and distribution however, they have open access to the grid for all renewable energy producers (Haucap, 2007). In Denmark, all energy projects need to go through a rigorous process to ensure their position is optimal for transmission purposes and that there is no opposition to their location and those environmental externalities are minimal, before they are approved. These policies have led to the creation of a well-planned and transparent electricity sector promoting competition, keeping costs down and fostering renewable energy. The model practised in Denmark also suggests that along with investment in renewable technology and infrastructure there needs to be incentives for complementary systems such as storage, demand response, smart grids etc. (Lund \& Mathiesen, 2009).

The largely market-based policy adopted towards renewable energy incentives and subsidies in the UK, have favoured large companies such as big developers, leading to high levels of public resistance (McHarg, 2015). A similar situation has been encountered in Ontario. Since 2009, with the Green Energy and Economy Act, the Ontario government has sought to develop renewable energy capacity in the province principally through a Feed-in-Tariff (FIT) but various other initiatives such as a micro-FIT, procurement programs, funding programs among others were also 
introduced (Canadian Co-op Association [CCA], 2011). Through various iterations of the programs the government has sought to encourage private community groups to become more involved in the programs and in renewable energy production (Mabee et al., 2012).

Though developed on similar models, in stark contrast to Germany and Denmark, the same amount of success has not been seen in Ontario. The installed renewable capacity amounts to about 3.5 percent of the total consumption in Ontario with few energy co-operatives participating in the process (Sustainable Prosperity, 2010). The Ottawa Renewable Energy Co-op (OREC) report (2013) points out that while there is a 'growing concern' about renewable energy projects especially in community-based initiatives, it is not reflected in grounded reality. In the past few months, the Ontario landscape has changed further, where large renewable procurement has been suspended, and Feed-in-tariff (FiT) and Micro-FiT's contracts were cancelled along with the repealing of the Green Energy Act (Ontario Ministry of Energy, Mines and Northern Development 2018). At the same time, due to technological advancements and high power prices, many modular energy generation technologies have become increasingly cost competitive with grid electricity, and their applicability to urban conditions are on the rise (The Globe and the Mail, 2015).

Another important factor that has been highlighted as further supporting development of community energy in the European examples is one of a culture of grassroots energy activism (Breukers \& Wolsink, 2007; Toke et al., 2008; Bauwens, et al, 2016). Bauwens et al., (2016) identify "Culture of local energy activism" as a part of their social-ecological framework for energy systems. Countries such as the Netherlands, Germany and Denmark have strong antinuclear citizen movements which gave rise to interest in renewable energy (Toke et al., 2008; Bauwens, et al, 2016). Along with a culture of community activism, many of these jurisdictions 
also have a strong cooperative movement, which further supports the flourishing of community energy in those areas (Toke et al., 2008; Huybrechts \& Mertens, 2014; Bauwens et al., 2016). As community energy and local self-generation gets more popular in urban areas, it should be noted that there are unintended consequences which can be damaging. Even though there is widespread support for local energy production and some level of understanding and appreciation for the benefit, people do not grasp the true implication of cutting the wire. On a personal scale, requiring the same level of energy security as with a grid is expensive to attain. There is also the challenge for utilities which in Canada are typically municipally-funded and should the off-grid model become dominant then utility stranded asset - risk increases exposing a financial burden to the taxpayer. Hence, while this research supports the benefits of local generation, it does not suggest mass defection from the utility, as that would create greater societal impacts.

\subsection{Spectrum of participation in community energy}

With community energy, the idea is to empower more people to participate from an early stage in projects that would allow them to share in the costs and benefits. Projects that do involve community ownership - through financial investment or managerial control by residents of the community (or on behalf of those residents) - have achieved this to different degrees and in different ways, mostly in the developed areas of the world (Stamford 2004; Walker et al., 2007). Different legal and financial models of ownership have been adopted globally. These models fall into three broad categories of community ownership in energy projects; developer or municipallyowned with citizen participation in the form of investors (Community Direct Investments), community organizations in partnership with a private party that owns and manages development (Joint Ventures), and energy projects owned and managed by the community (Community Owned 
and Managed). Figure 2.2 provides a visual representation of the spectrum of citizen participation in community energy projects.

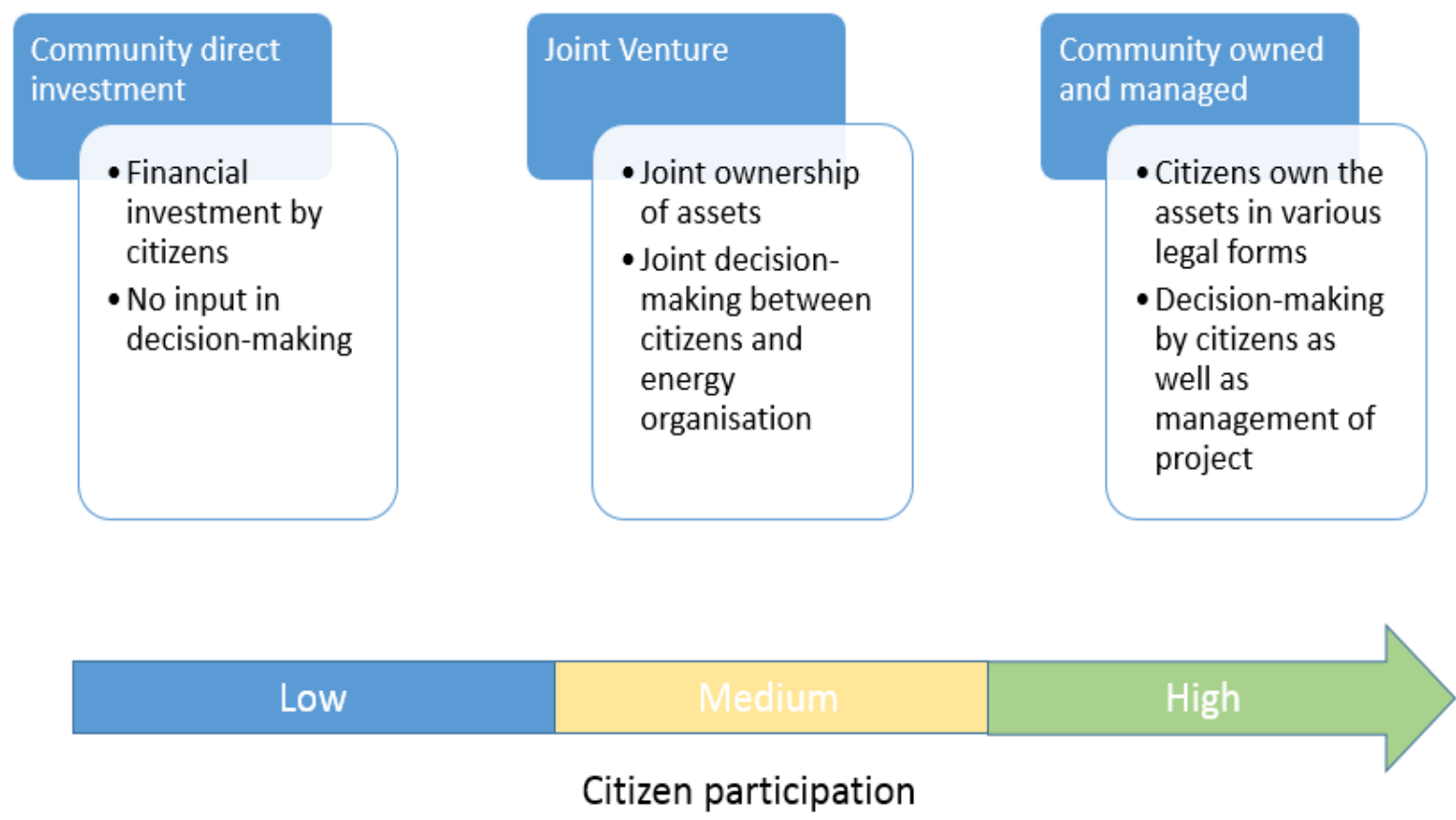

Figure 2.2 - Spectrum of citizen participation in community energy

1. Community owned and managed energy projects: This category of project is characterised by high levels of citizen/resident participation. The participation would involve leading, managing and financially investing in local community energy projects.

2. Community joint venture: This category involves models, which solicit medium level of participation. This is characterised by a joint venture model, where third party Company such as a developer leads the community energy development with investment of time and money from the community members. 
3. Community direct investments: These are characterised by their relatively low requirement of participation. Community members invest their money but do not have any other decision-making powers, abilities, or significant time commitment to community energy projects.

This three level categorization (low, medium, high) is intended to be useful in providing a simple model of understanding, while also encompassing the heterogeneity present among interests of participants, which has been theorised and proved in numerous previous studies (Jager, 2006; Bergek et al., 2013; Bauwens, 2016; Mignon and Bergek, 2016). Table 2.1 below identifies international examples of community energy projects that utilise these three broad categories of ownership and management.

\section{Community Owned and Managed}

Many different legal ownership structures exist under the community owned and managed category. Examples include:

\section{Cooperatives}

People in the local community or further afield become members of the cooperative and buy shares to finance the project (Bolinger, 2001; Stamford, 2004).

\section{Community charities}

These are usually in the form of an association with charitable status that provides or runs facilities for the local community, such as community centers, which use renewable energy to heat or power their buildings. For example, they can manage energy projects, as with the biomass district heating network in Kielder, Northumberland (Walker et al., 2007).

Jühnde bioenergy village is an excellent example of a community-owned and managed project. Jühnde (Lower Saxony) is Germany's first village to produce heat and electricity using renewable 
biomass (wood chips, agricultural wastes), in their efforts to create a carbon neutral village. The biomass, sourced locally is easy to obtain and provides the necessary flexibility to the system. Heat supply in a year is about 4.5 TWh, and there is a local heating grid in the village (Mergner \& Rutz, 2014).

Table 2.1 - Examples of different community owned projects

\begin{tabular}{|c|c|c|c|}
\hline Project type & Project & Country & Project description \\
\hline \multirow{4}{*}{$\begin{array}{l}\text { Community- } \\
\text { owned and } \\
\text { managed }\end{array}$} & $\begin{array}{l}\text { Jühnde bioenergy } \\
\text { village }\end{array}$ & Germany & $\begin{array}{l}\text { Community-owned. Energy utilized to } \\
\text { heat the village. }\end{array}$ \\
\hline & Glimminge Vind & Sweden & Real estate commune \\
\hline & Amsterdam Zuid & Netherlands & Community owned solar collective \\
\hline & $\begin{array}{l}\text { Brooklyn Microgrid } \\
\text { (pilot) }\end{array}$ & US & $\begin{array}{l}\text { Individual ownership of resources who } \\
\text { then supply to other peers }\end{array}$ \\
\hline \multirow{3}{*}{ Joint venture } & $\begin{array}{l}\text { Middelgrunden Wind } \\
\text { Cooperative }\end{array}$ & Denmark & $\begin{array}{l}50 \% \text { owned by the } 10,000 \text { investors in } \\
\text { the Middelgrunden Wind Turbine } \\
\text { Cooperative, and } 50 \% \text { by the municipal } \\
\text { utility company. Energy sold to the grid. }\end{array}$ \\
\hline & Earlburn Wind Farm & Scotland & $\begin{array}{l}\text { Joint venture between company created } \\
\text { by the community and the developer. }\end{array}$ \\
\hline & $\begin{array}{l}\text { Neilston Community } \\
\text { Windfarm }\end{array}$ & Scotland & $\begin{array}{l}\text { This is a } 4 \text { turbine, } 10 \mathrm{MW} \text { joint venture } \\
\text { between the Neilston Development } \\
\text { Trust and Carbon Free Developments } \\
\text { Ltd. Trust owns a } 28 \% \text { stake, can be } \\
\text { increased up to } 49.9 \% \text {. }\end{array}$ \\
\hline \multirow{3}{*}{$\begin{array}{l}\text { Community } \\
\text { Direct } \\
\text { Investment }\end{array}$} & $\begin{array}{l}\text { Sacramento Municipal } \\
\text { Utility District } \\
\text { (SMUD): SolarShares } \\
\text { Program }\end{array}$ & US & $\begin{array}{l}\text { Utility owned, community members buy } \\
\text { shares. }\end{array}$ \\
\hline & $\begin{array}{l}\text { Solar community } \\
\text { energy project in } \\
\text { Recklinghausen }\end{array}$ & Germany & $\begin{array}{l}\text { Small company ownership structure } \\
\text { with shares owned by investors. Energy } \\
\text { sold to the grid. }\end{array}$ \\
\hline & Frieamt & Germany & $\begin{array}{l}\text { Village of nearly } 4300 \text { residents, which } \\
\text { owns many different types of generation } \\
\text { technology. Private company ownership } \\
\text { structure with over } 200 \text { shareholders. }\end{array}$ \\
\hline
\end{tabular}

Jühnde bioenergy village was supported by government initiatives and invested community raised capital of around 5.3 million euros (EUR) - approximately $\$ 8$ million Canadian dollars- into the project implementation. FNR (Fachagentur Nachwachsende Rohstoffe e.V., a government 
initiative to support renewables) took over the financing of the research activities and covered a portion of the investment costs for the district heating network (1.3 million EUR). The planning and the authorization phase was supported with 55,000 EUR from the LEADER+ Programme (European Union initiative to support rural development projects). Finally, the State of Lower Saxony and the district of Göttingen supported the project with 100,000 EUR (Mergner \& Rutz, 2014).

Similarly, Glimminge Vind, a project in Sweden used a real estate commune structure of ownership for their project. An unusual structure by Western standards, these communes are based on the traditions of Swedish common law and communal ownership of physical resources, such as fishing or grazing rights, which were often attached to land titles (e.g., one must own land along a stream or in a village in order to fish in that stream or pasture livestock in the village field). Somewhat unique to Sweden, this common law tradition has evolved into a modern vehicle for communal ownership of public facilities such as parking lots, playgrounds, and now wind turbines (Helby, 1998; Bolinger, 2001). Fifteen farmers and four individuals own the commune locally. There is a $500 \mathrm{~kW}$ Wind Turbine located in one of the farmer's fields. The project, which was completed in early 1995, received a $35 \%$ capital investment subsidy from the government, with the remaining $65 \%$ of capital raised through the sale of 950 shares of 1000-kilowatt hours $(\mathrm{kWh}) / y e a r$, which equates to an expected capacity factor of about 22\%. Each share cost SEK 2500 ( $\$ 320)$, and the number of shares per owner varies from 10 to 250 , depending primarily on each owner's energy consumption (Bolinger, 2001).

Another example is a community pilot project being conducted in New York City, called the Brooklyn Microgrid (BMG). It is a network of energy relationships between neighbours and the energy company, supporting the generation of renewable energy within the local neighbourhood. 
This project began in early 2015, with the first community activities starting in April 2016. The first-ever peer-to-peer transactions occurred among neighbours who did not have their own solar panels and with those who did and produced excess solar power (Cardwell, 2016; Mengelkamp, et al., 2086; Morstyn et al., 2018). This project is a pilot that has been created in partnership with LO3 Energy, a local start-up company, Siemens Digital Grid, and Siemens' start-up financer next47, to test a blockchain-enabled microgrid in Brooklyn. The system is built using LO3 Energy's "TransActive Grid", a blockchain platform that timestamps each transaction as a chain of secure blocks and documents every energy transaction. Siemens Digital Grid offered its' microgrid-specific technical solutions - Microgrid Energy Management Platform and next47 supports potentially disruptive technologies like this through financing, project expertise, and advice (Brooklyn Microgrid, 2017). If successful, this project would perhaps most closely resemble the future of electricity systems, as it enables peer-to-peer energy transactions.

The Amsterdam Zuid project is also a leading example of urban community energy project, led, managed and owned by citizens themselves. A community located in the south of Amsterdam, this is a floating community consisting of about 80 houseboats, some of whom have been resident in the area since the 1960s. With the government launching a solar subsidies program in 2008 , a few of the houseboat owners were interested in purchasing solar Photo-voltaic (PV) panels for their personal use. They set about recruiting others with the help of the local association. Social networks played a key role in getting more individuals to join the project. Policies were the key drivers for the investment decision by individuals, and these included a tax exemption program called Saldering (meaning balancing in Dutch) that guaranteed that up to $5000 \mathrm{~kW}$ h/year of the behind-the-meter produced electricity is exempt from VAT and energy tax. ${ }^{2}$

\footnotetext{
${ }^{2}$ https://www.hieropgewekt.nl/kennisdossiers/zelflevering-saldering
} 


\section{Joint Ventures}

While community owned and managed systems are exciting, not everyone is interested in managing projects (St. Denis \& Parker, 2009). Some examples of joint ventures could be through a community organisation partnering with a developer who then manages the project on behalf of the community. Some common legal forms are as follows:

\section{Development or land trusts}

These have been used in Scotland and Sweden primarily to represent communities' interests in revenue-generation enterprises, and in some cases, this has been extended to include variants of community ownership (Bolinger, 2001).

\section{Shared ownership}

The gifting of shares in a commercial project to a local community organisation such as a trust, or in the case of wind farms, the gifting of one or more turbines (as at Earlsburn wind farm in Scotland) has been used as a way of providing a community benefit that is closely tied to the performance of the production unit (Walker, 2008). Part-ownership by the community may confer only limited rights to control or to make inputs into decision-making. The Middelgrunden wind farm in Denmark is a famous example of a community energy project. At the time of construction, it was the largest offshore wind farm consisting of 20 turbines at 2 MW each (Sørensen et al., 2000). The wind farm currently powers $3 \%$ of Copenhagen's electricity needs and at its inception the Middelgrunden Wind Turbine Cooperative, with roughly 10,000 members, owned ten turbines, while the remaining ten turbines were owned by Copenhagen Energy, the local municipal utility (Bolinger, 2001).

\section{Community Direct Investment}

Another model is that of direct community investment in community energy projects which involve citizens as investors but who have no say in the day-to-day running of the project. A good 
example is that of the solar community energy project in Recklinghausen, Germany where it was recognized that public roof surfaces in cities could be easily used for the generation of electricity and heat. The citizens of Reklinghausen decided to exploit this potential with a community power project that, since July 2011, has fed electricity from three PV systems into the power grid. The plant produces approximately 195,000 kWh of electricity per year (Mergner \& Rutz, 2014). The city of Recklinghausen supports the initiative through the lease of the roof surfaces for the PV cells. Investment costs of the project were 220,000-260,000 EUR and 100\% was financed with local citizens providing the capital resources. They could participate in the project with a minimum investment of 500 EUR. The average investment amount was 3,300 EUR. In total three GbRs (Gesellschaft bürgerlichen Rechts - Companies of Civil Law) were established to own and manage the project. Also, a union (Verein) SolaRE e.V. was established, responsible for the construction and operation of the PV systems, while the three GbRs containing 70-80 citizens each were financing and using the solar systems (Mergner \& Rutz, 2014).

Another project utilising a "citizen as investor" model include the Sacramento Municipal Utility District (SMUD) SolarShares Program. The program provides opportunities for customers to benefit from the use of solar PV systems without owning them. These customers agree to participate in the program by purchasing solar power that SMUD buys from local, communityscale PV systems under 20 year contracts and in return receive any net metering benefits that these systems may provide. SolarShares began in mid-2008 using a 1-MW system that has produced an average 1,745 MWh per year, with approximately $86 \%$ of that production being sold to SolarShares 600 participants (Coughlin et al., 2012). As the price for non-solar energy rises, it is expected that these participants could eventually realise monthly savings on their solar purchase. 
The literature and case examples would suggest that community participation in local energy projects could provide immense benefits. However, there are significant issues that arise from large capital outlays associated with these projects. MinWind, a farmer-owned wind farm in Southwestern Minnesota, is a prime example of failure of a community project, due to unforeseen issues. Substantial damage to the wind turbines arising from an ice storm in 2013 resulted in the need for substantial repairs and the owners could not raise the capital in time to keep the wind farm running in order to meet their supply obligations to the region's electricity utilities. The MinWind project consisted of nine turbines (each organised as an independent limited liability corporation (LLC)) and received support from the government in the form of grants and a higher tariff for the wind energy produced. The federal tax credits were passed down to the individual owners. This project was one of the first wind farms in Minnesota, and the project was generating revenue for ten years prior to the ice storm. The repair cost issue was further compounded by other federal regulatory issues, leading to the owners filing for bankruptcy in early 2015 (Farrell, 2016).

Hence, along with the benefits, there are challenges to community ownership as well. Financial issues such as raising capital can be an important roadblock, other issues such as lack of expertise, along with regulatory compliance (Haggett et al., 2013; Nolden, 2013; Ofgem, 2015). In addition, not everyone is interested in managing an energy project. Previous research finds that though there is good support for local generation and renewable technologies, the desire for active involvement is lower. Community members were most interested in participating as consultees rather than leading projects (Rogers et al., 2008). St. Denis \& Parker's (2009) analysis of 10 of the first community energy plans in Canadian communities finds that smaller and more remote communities may be the most willing to lead in the planned introduction of renewable energy systems. 
Many of the examples cited above are in rural areas. The rural areas were the natural choice for siting due to the land intensive nature of technologies (e.g. Wind). However, with availability of cost effective technologies, generation in urban areas is increasingly viable, even when it is behind the meter. Not many big urban centres are adopting community energy yet with the most important exception being that of Berlin (Blanchet, 2015; Angel, 2016) which has previously tried to re-

municipalise the energy network and create a new, participatory public utility and now has a spectrum of community energy projects with collaborative decision-making at various levels of active participation (Kunze \& Becker, 2015). The community energy approach can be a solution to the challenges of financing renewable energy projects by presenting a reasonable business model that raises capital from private individuals and provides a return on that investment. However, return on investment alone may not drive participation in community energy projects and it is important to recognize that other factors can motivate people to participate in local community generation.

\subsection{Behavioural motivation}

Many studies have tried to identify the motivation for citizens to participate in community energy projects (Palm \& Tengvard, 2011; Dóci \& Vasileiadou, 2015; Holstenkamp \& Kahla, 2016). Table 2.2 lists motivating factors that are important for encouraging a positive attitude and participation of people in local community energy projects (Balcombe et al., 2013, Dóci and Vasileiadou, 2015). 
Table 2.2 - Motivations for participation in community energy projects (after Dóci and Vasileiadou, 2015)

\begin{tabular}{|l|l|}
\hline Motivating Factors & Description \\
\hline Financial & $\begin{array}{l}\text { Reduce energy bills, make money from selling energy, increase of } \\
\text { property value }\end{array}$ \\
\hline Environmental & Concerned for the environment \\
\hline Security of supply & $\begin{array}{l}\text { Not facing outages, future high costs of electricity and be more } \\
\text { energy independent }\end{array}$ \\
\hline Uncertainty and trust & $\begin{array}{l}\text { Use of an innovative or high end technology leading to trust } \\
\text { Social norms }\end{array}$ \\
$\begin{array}{l}\text { Follow what others are doing, act in accordance with what's } \\
\text { expected by society }\end{array}$ \\
\hline
\end{tabular}

\section{Financial motivation}

As mentioned in various other studies (Dóci \& Vasileiadou, 2015; Bauwens, 2016), financial concerns are dominant in decision-making and this is understandable from the perspective of the goal-frame theory as discussed by Dóci \& Vasileiadou (2015). The gain goal-frame is the motivation that promotes resource accumulation and protection, which provides individuals with "all kinds of incentives or opportunities which promise benefit." (pp 43). Rational choice theory suggests that individuals make decisions in pursuit of their own objectives. Dóci \& Vasileiadou (2015) describe it as the gain goal framework of motivation. Roger Myerson (1991 p. 2) says, "a decision-maker is rational if he makes decisions consistently in pursuit of his own objectives. We assume that each player's objective is to maximize the expected value of his own payoff, which is measured in some utility scale."

In a community energy context, personal financial benefits can be achieved in the following ways:

- Revenue generation through selling of energy or cost savings from producing own energy or buying energy at reduced prices

- Increase in property value 
Since financial motives are considered a strong indicator of attitude towards renewable energy, it has been theorised that business models that clearly articulate citizen financial benefits, are likely to spur adoption of renewable energy technologies (Jobert et al., 2007; Lindenberg \& Steg, 2007; Warren \& McFayden, 2010). In Ontario, there have been public discussions around electricity prices over the past few years. ${ }^{3}$ Concerns around high delivery fees have especially been highlighted and as such could lead to higher motivation for adoption of local generation and participation in community energy projects if it were to positively impact delivery fees or present the appearance thereof.

\section{Social norms}

The gain goal framing of motivation and emphasis on financial benefit has been considered a simplistic view of the individual (Bergman and Eyre, 2011; Sauter and Watson, 2007). Especially in a social context of a community energy project, there are other motivators that influence behaviour. One such important factor is social norms. Within social norms can be identified normative goals that can provide the motivation for positive environmental behaviour. Dóci \& Vasileiadou (2015, pg. 43) describe this phenomenon as "Within the normative goal-frame people act appropriately and behave ethically or morally. Their main goal is to meet norms expected by themselves or the community. It is more likely that people act according to normative goal-frames, if they are aware of environmental problems. However, the dominance of this goal-frame is reduced, if costs increase or the act becomes too complicated or time-consuming." The roles of norms have gained increasing attention in the literature on community energy investments. For instance, Mignon and Bergek (2016) report that some people invest in renewable electricity

\footnotetext{
${ }^{3}$ https://www.theglobeandmail.com/news/national/why-does-electricity-cost-so-much-in-ontario/article33453270/
} 
production to follow the behaviour of their friends, neighbours and peers in an effort to gain acceptance and recognition.

Descriptive norms and injunctive norms have been described as two underlying factors for the effectiveness of social networks. Descriptive norms arise from the human biological urge of imitation. Imitation has been shown to be evolutionarily important for human beings and have led to the transformation of societies (Bamberg, et al., 2015). This urge to be like others is what gives rise to the effectiveness of descriptive norms, which has led to such certain phenomena e.g. recycling gaining increasing popularity and normative acceptance. To quote Jager (2006, pp 1938) "When a consumer has a direct contact with, for example, a neighbour or friend who has successfully installed a PV system, social comparison processes may facilitate the exchange of information, both on the satisfaction they derive from owning a PV system and on the technical and administrative procedures. This would reduce the complexity of the decision-making context and make the situation more favourable for adoption. Especially in such complex decision situations, network effects may play a crucial role in people's decisions to adopt. The more people in a social network who have already adopted a PV system, the more information will be available." The other norm discussed in literature that impacts behaviour is the injunctive norm. This norm describes the behaviour that is expected from individuals by their friends and family and reference group (Curtius et al., 2018). Injunctive norms are what sets the benchmark for behaviour by creating a common perception of what something ought to be like. What others expect of us motivates our behaviour.

Social network effects have been long studied in the diffusion of innovation, along with social norms (Delre et al., 2004). Social networks are often channels of information transfer and are useful, for community initiatives which do not have huge marketing budgets and rely on word of 
mouth viral marketing through social networks. Bauwens' 2016 study conducted a survey among the members of the cooperative Ecopower which showed that "almost $30 \%$ of members came to know of the organisation by word of mouth (Ecopower, 2013)." (Bauwens, 2016; p 280). Tyler and Blader (2001) have considered that social identification with a group promotes cooperative behaviour and collective action, as one required for initiating and running a community energy project. A large body of research has shown that social norms conveyed by reference groups such as neighbours have a powerful effect on people's behavior in a range of domains, including energy conservation and recycling (Nolan et al., 2008). According to Cialdini (1983), people conform to descriptive norms in particular under conditions of high uncertainty. The decision to change how to get energy, creating a community energy project, involves substantial investment, and occurs in changing policy and market conditions. Hence, descriptive norms are expected to be a factor of high significance.

\section{Environmental}

Early studies have shown that consumers do not act in accordance with economically rational theory (Tonn and Berry 1985) and there is a consensus among more recent studies that consumers do not make decisions that are considered to be economically rational with respect to energy (Hoffman \& High-Pippert, 2005; Wilson \& Dawlatabadi, 2007; Hoicka, 2012; Lavrijssen, 2014).

Lavrijseen says, (2014, p. 280):

"Considering the characteristics of the energy market and the external effects of consumer behavior on this market, there are good reasons to argue that a target group-specific consumer policy in the energy sector is justified. From a legal perspective, this would mean that the average energy consumer would not be interpreted as a rational Homo Economicus. Instead the average energy consumer is seen as a real, trusting consumer with limited time and certain biases who may need some extra help to participate in a rational and responsible way in the energy market." 
Therefore, financial factors may not be sufficient to influence behaviour, especially when it comes to pro-environmental behaviour (Hoicka, 2012). Studies have shown environmental awareness and subsequent concerns to be important drivers of pro-environmental and ecological behaviour especially as it relates to community energy initiatives (Bauwens, 2015). Environmental attitude and ecologically minded behaviour has been the subject of previous studies (Kaiser et al., 1999; Kollmuss \& Agyeman, 2002). Kaiser et al, 's 1999 work argues that attitude influences behavior and attitude is in turn affected by knowledge and values. Knowledge and awareness is an important factor for motivation to participate in community energy projects (Hausbeck et al., 1992; Kollmuss \& Agyeman, 2002). As for the values part as described by Kaiser, it is essentially social, norms (described above). Kalkbrenner and Roosen (2016) too have considered environmental concerndriven behaviour to be a subset of social and environmental norms. Hence, there is some argument about environmental concerns being a separate factor or actually a subset of social norms + awareness and education. For the present study, the researcher is identifying environmental concern as a separate factor distinct from social norms.

\section{Uncertainty \& trust}

Individual motivations to invest and participate in local community energy projects can also be explained from the innovation adoption perspective (Bergek et al., 2013). In the innovation adoption literature, investment decisions are not uniform across a population of potential adopters and this heterogeneity in interests in participation has been discussed by Bauwens (2016). According to Roger's (1995) theories on innovation, different population segments can be distinguished according to their attitude to the diffusion of innovations: 'innovators' are the first group to purchase a new product in its 'introduction' phase. Innovators' have other characteristics 
such as high-risk tolerance and niche interests. This group is followed by the early adopters, who adopt technologies early in their life cycle when a clear benefit is seen.

Balcombe et al. paper (2013, p. 660) identifies the following as further concerns:

- "System performance or reliability not good enough

- Energy not available when I need it

- Hard to find trustworthy information/advice

- Hard to find any information/advice "

According to Caird and Roy (2010), uncertainty related to new technology performance and reliability were motivation for non-adoption with $58 \%$ of respondents in a study conducted in the UK. Uncertainty related to technology as a motivator has featured in policy documents such as the UK Microgeneration Strategy as well (UK Government, 2011).

\section{Security of supply}

Security of supply is a common concern regarding energy supply. Security of supply has been studied as a motivator for local technology adoption (Jager, 2006; Palm and Tengvard, 2011; Balcombe et al., 2013) as well as for participation in community energy projects (Dóci \& Vasileiadou 2015). Participants of Jühnde community energy case study conducted by Dóci \& Vasileiadou (2015) project identify that one of the main reasons to join the project was to avoid having to run out of fuel in middle of winter and then having to wait for supply. Similarly, Freiamt and Thermo Bello case studies too spoke about the motivation to be secure from future oil price hikes as a reason to participate in the local community energy project (Dóci \& Vasileiadou 2015). Security of supply also encompasses freedom and independence from traditional methods of power and fuel supply, which are seen to be unreliable (Balcombe et al., 2013). In the past few years Toronto has faced some effects of extreme climate change events such as heavy rains leading to flash flooding and ice storms. These storms have caused damage to power infrastructure disrupting power to residents disrupting the normal flow of life. Hence, for the purposes of the present study 
the phrase security of supply, will be used as it relates to un-interrupted supply in the event of an extreme weather event.

\subsection{Demographic factors and relations to participation in community energy}

Age

Studies show that the very young and old both show a disinclination in participation in community energy projects. Access to capital for younger participants has been considered a barrier to investment, and older people are not motivated to participate due to issues of uncertainty and trust (Willis et al., 2011; Balcombe et al., 2013).

\section{Building type}

In an urban context, building type could possibly have an impact on the ability or interest to take up renewable energy technologies. The literature is void of studies specifically identifying the impact of different building types on decision-making regarding adoption of renewable energy technologies as well as community energy participation. Yet, in an urban setting, multi-residential buildings would have occupants who are more used to a communal approach i.e. shared facilities and costs than someone who lived in a detached or semi-detached dwelling. This might have some moderating effect on the willingness to participate in a community energy project. Furthermore, in an urban context, siting of projects would be crucial. Apartment buildings might not have communal space readily available for development of energy projects. Building integrated photovoltaics might be a solution to this spacing challenge in urban high rise buildings (Redweik et al., 2013), but building conditions will continue to play a role in the adoption decision process.

\section{Building ownership}

Ownership (land/building) is a big influencer on adoption of local energy generation technologies (Kierstad, 2007). Fischer and Sauter (2003) differentiate between owners and tenants 
of single dwellings and apartment/condo dwellers, and they suggest that due to direct ownership, decision-making for adoption of local generation is simplified; hence, owners principally participate in local generation. Owners of property who live on premises also have a direct financial motivation in benefiting from fuel bill savings, as opposed to landlords and housing associations where these savings are normally passed on to the tenant (Michelsen \& Madlener, 2012; Balcombe et al., 2013; Strupeit \& Palm, 2016). Tenants who do not pay electricity bills have less of a financial motivation to participate in local generation although where savings are passed on to renters there may be motivation to encourage fuel bill savings. Other motivations discussed above such as environmental or social norms may be similar irrespective of ownership status. Furthermore, investing in community owned infrastructure might be more lucrative to owners when compared to renters who may see this as a landlord decision.

\subsection{Principal Research Question}

Because of the review of the literature on community energy projects and factors that motivate community adoption, it is increasingly apparent that due to cost competitiveness and other considerations of reliability and security, many people are increasingly interested in exploring local generation options. As this research is concerned with the urban environment and how community energy can be adopted in such a scenario, it seeks to answer specifically the following question:

How can community energy manifest in urban centres? This principal question around participation is further divided into the following two questions:

1. What level of participation are people interested in when it comes to community energy projects?

2. What motivates the different levels of participation in urban community energy projects? 


\section{Methodology}

To answer the principal research question, an interpretivist (also known as constructivist) paradigm has been deemed most suitable. The interpretivist paradigm assumes that reality as we know it is constructed inter-subjectively through the meanings and understandings, which are established socially and experientially (Kelliher, 2011). The subjective epistemology states that the researcher cannot separate himself or herself from the knowledge. It states that truth is negotiated through dialogue. Thus, what we know is always negotiated within cultures, social settings, and relationships with other people. Since, the validity of truth cannot be grounded in objective reality, from this perspective, validity or truth being negotiable leads to multiple, valid claims to knowledge (Schwandt, 1994).

Neuman (2002) states that there are two forms of data collection, qualitative (QUAL) and quantitative (QUAN) and presents very structured definitions for what these terms mean. Whereas quantitative data collection deals with numbers, qualitative data collection deals with words or pictures. Quantitative methods have been the dominant methods of study for sciences and also social sciences for most part of the $20^{\text {th }}$ century (Teddlie \& Tashakkori, 2009). They use statistical data analysis to answer research questions. Quantitative methods of inquiry subscribe to positivistic paradigm and are not completely adequate to answer the questions posed. Many studies support the view that the interpretivist paradigm needs to utilise qualitative methods. (Thomas, 2003; Willis \& Jost, 2007; Thanh \& Thanh, 2015). It is also supported by Merriam's (1988) assumptions on qualitative research:

- The researcher is the primary instrument for data collection and analysis

- This study is concerned primarily with a process rather than just outcomes or products

- It is interested in meaning: i.e. community energy, participation in community energy and, 
- The researcher is seeking to understand how behavioural motivations impact collaborative ownership and management model and boost participation in community energy projects.

Hence, a qualitative inquiry is explored as well. Cassell and Symon (1994) defined qualitative research in the following way:

"a focus on interpretation rather than quantification; an emphasis on subjectivity rather than objectivity; flexibility in the process of conducting research; an orientation towards process rather than outcome; a concern with context — regarding behaviour and situation as inextricably linked in forming experience; and finally, an explicit recognition of the impact of the research process on the research situation" ( $\mathrm{p}$ 154). This definition brings forth the key features of qualitative research and contrasts itself with quantitative research.

The main issues concerning the theory of knowledge relate to questions of meaning and verification. In qualitative research, humans construct meaning as they engage with the world, and, open needed questions are used so that participants can express their views on the topic. Historical and social perspectives are valuable. Thus, the researcher needs to understand the setting of participants. This understanding is also based on the researcher's personal experience. There is a social construction of meaning, which arises out of human interactions. However, relying only on a qualitative method is insufficient, especially as the research aims to identify behavioural motivations within a larger population. From the literature on consumer behaviour there is some support for the use of mixed-methods for research aimed at understanding behavioural motivations (Hausman, 2000). Furthermore, according to the theory of pragmatism, knowledge claims result from actions, situations and consequences rather than original conditions as seen in postpositivism. The primary emphasis is on a solution to problems (Patton, 2005) and thus, in pragmatism, it is the problem that is important and not the methods. Pragmatism is not bound by or connected to any one system of philosophy and reality (Creswell et al., 2003). The researcher 
has the freedom of choice in technique and methods that best suit the research purpose. This argument supports mixed methods, focusing attention on the research problem and utilising multiple approaches to derive knowledge.

Delanty \& Strydom (2003) are of the opinion that in the recent years there has been a "decline in disciplinarily" and that "the natural, human and social sciences can no longer be so sharply separated from each other as in the tradition of the three cultures of science that grew out of the institutionalization of science" (p. 58). This view is mostly because of the rise of new discourses such as the environmental studies in which the social and the natural sciences share many concerns. Delanty \& Strydom (2003) go on to say that the field of environmental studies has "problematized the ontological distinction between humans and nature" (p. 44) due to the interrelations and complexity being presented by environmental issues. Hence, mixed methods are increasingly becoming the method of choice for environmentally- focused study, such as when discussing issues of sustainability and the complex relations between economic, social and environmental factors.

Mixed methods (MM) as a research paradigm, can be seen as combining the constructivist elements of qualitative research with the positivistic elements of quantitative research methods. This approach can be sequential or parallel, with the quantitative and qualitative methods used alternately or together to investigate the same phenomenon. Multiple approaches to data collection and examination, as practised in mixed methods inquiry, believes that inherent biases of a single method will cancel the biases of the other method. Data analysis could involve both statistical and text analysis of data. Mixed method design can utilise the best of both qualitative and quantitative lines of inquiry. Many researchers in the field of environmental research/community research are utilising mixed methods in their inquiry (Johnson \& Onwuegbuzie, 2004; Driscoll et al., 2007). 
Teddlie \& Tashakkori, $(2003,2006,2009)$ have done a lot of thinking on the use of mixed methods, especially for studying social and behaviour sciences and support its use as a method.

Historically, mixed methods research ended the paradigm wars and the "incompatibility wars" because it combined the quantitative and qualitative research methods. From the $19^{\text {th }}$ century to the 1950s, the purist approach to research utilised one single data source or several lines of evidence within a quantitative or qualitative research paradigm. Figure 3.1 below shows the traditional mono-method research design vs. the mixed-method research design:

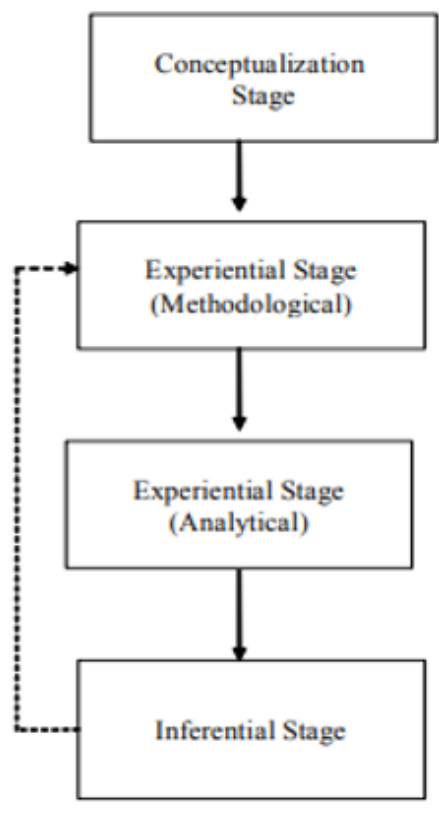

Traditional mono-method research design

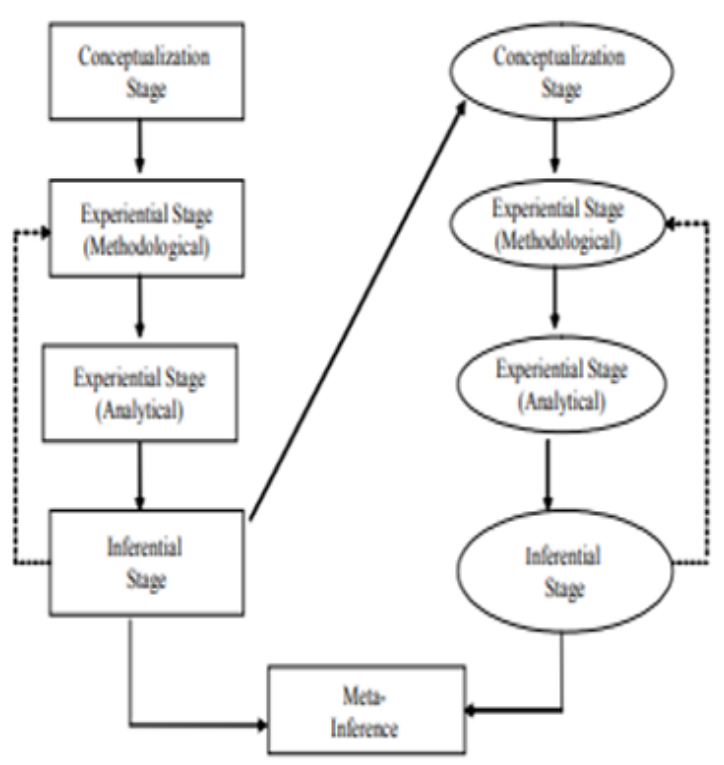

Mixed-method research design

Figure 3.1 - Traditional mono-method research design and sequential mixed-method research design comparisons (Teddlie \& Tashakkori, 2006, p 16, p 22)

Mixed-method research design can be done in a few different ways. According to a matrix created by Teddlie \& Tashakkori, (2006), four main ways are: 
- Concurrent: This type of MM is the most commonly understood family of research design as described by Teddlie \& Tashakkori, (2006, p. 20) where two parallel inquiries "one with QUAL questions and data collection and analysis techniques and the other with QUAN questions and data collection and analysis techniques. Inferences made based on the results from each strand are synthesized to form meta-inferences at the end of the study". Teddlie \& Tashakkori, (2006, p. 21) further go on to say that "While Concurrent Mixed Designs are very powerful, they are challenging to conduct due to the complexity of running multiple strands of research simultaneously." In previous research employing this method, different groups of researchers conducted the QUAL and QUAN phases, and are generally considered hard for a single researcher to undertake (Teddlie \& Tashakkori, 2006).

- Sequential: In this MM designs, two streams of data are collected and analysed sequentially in two phases (QUAN or QUAL) where the results of one are used to inform the next phase. Here, the data analysis has to be done in phases and started before all the data is collected. According to Tashakkori \& Teddlie (1998, pp. 149-150) "multiple approaches to data collection, analysis, and inference are employed in a sequence of phases. Each phase, by itself, may use a mixed approach and provide conceptual and/or methodological grounds for the next one in the chain".

- Conversion: "The Conversion Mixed Design is a multistrand concurrent design in which mixing of QUAL and QUAN approaches occurs in all components/stages, with data transformed (qualitized or quantitized) and analyzed both qualitatively and quantitatively" (Tashakkori \& Teddlie, 2003, p. 706).

- Fully integrated: Finally, "a multistrand concurrent design in which mixing of QUAL and QUAN approaches occurs in an interactive (i.e., dynamic, reciprocal, interdependent, 
iterative) manner at all stages of the study. At each stage, one approach (e.g., QUAL) affects the formulation of the other (e.g., QUAN)" (Tashakkori \& Teddlie, 2003, p. 708). Based on Creswell's writings on the topic (2006), along with others Tashakkori \& Teddlie (2006), and research from the area of consumer behaviour (Hausman, 2000), the study follows a sequential QUAL $\rightarrow$ QUAN mixed-methods approach. The following simplistic diagram,

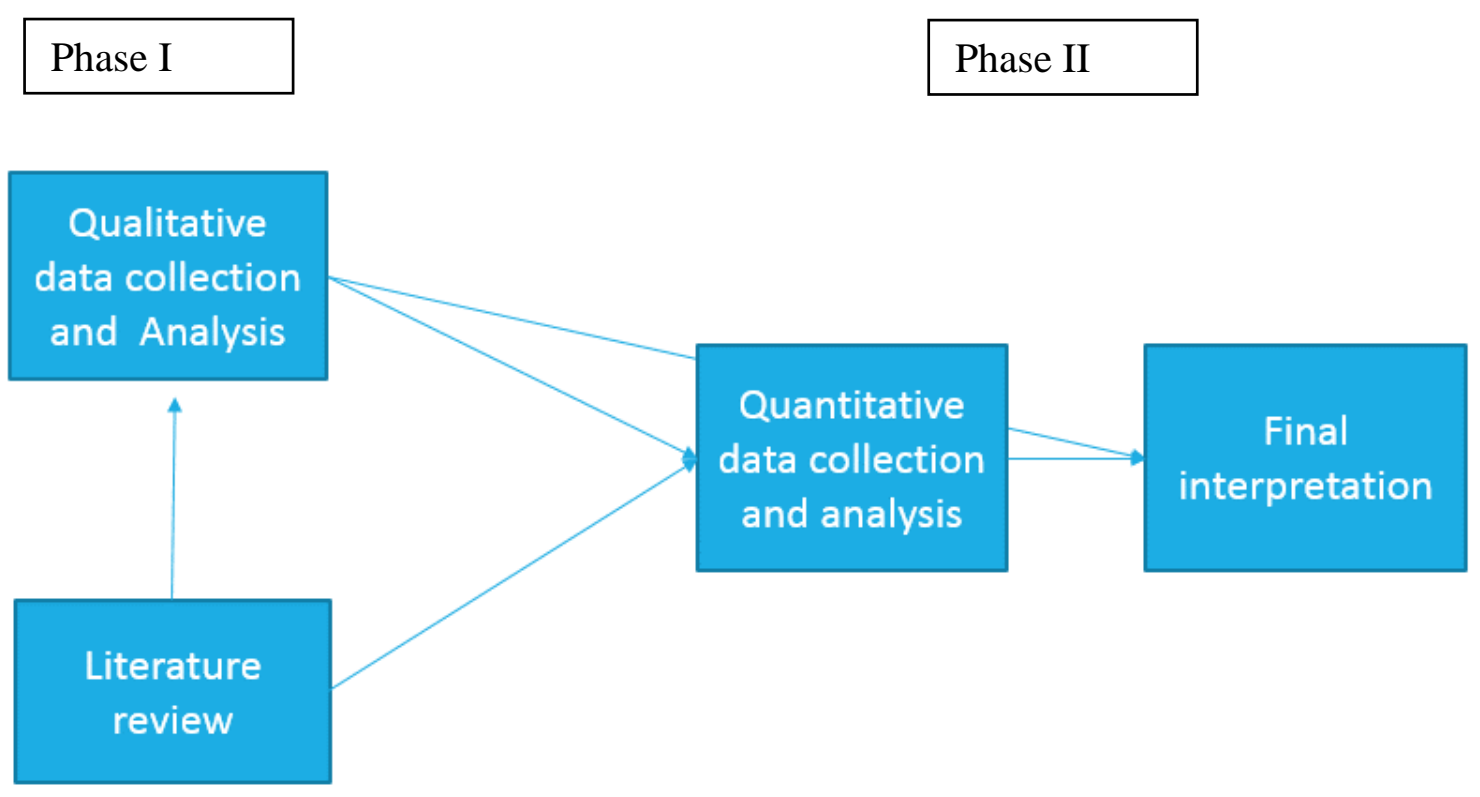

Figure 3.2 - Sequential Mixed-Methods Research Design

Following Hausman's research design, the current research utilises sequential MM, with semistructured interviews for qualitative data collection in phase I, followed by quantitative data collection and analysis in phase II. Previous research into behavioural studies have used mixedmethods research involving interviews and questionnaire surveys (Cresswell et al.,2003; Tashakkori \& Teddlie, 2003). These methods have been mixed to identify factors that influence behaviour of different types. The same technique of mixed methods has been used in this current research to identify factors that influence decision-making regarding adoption of local generation 
and participation in community energy. The qualitative and quantitative methods used are facilitating the understanding and theory development for participation models and behavioural motivations corresponding to different community energy models, by residents of Toronto. The analysis will use quantitative and qualitative data to identify the factors motivating the residents of Toronto to participate in different models of community energy. Policies can then be put in place to promote the models most favoured by consumers and create programs and projects that gets community buy-in and brings sustainable prosperity to urban communities in Ontario and Canada.

\section{Phase I: Interviews}

Interviews are an important tool for qualitative data collection and as King \& Horrocks (2010) observed, the interview research method is the essential tool for the collection of data in social research as it is all about the direct systematic conversation between an interviewer and the respondent. By this, the interviewer can get relevant information for a particular research problem both extensively and intensively, and exchange the data and experiences. Interviews can be categorised into three fundamental types: structured, semi-structured and unstructured. Structured interviews are, essentially, questionnaires asked out verbally, where the questions are predetermined and no scope for elaboration. Hence, they are fast and easy to use, but they only allow

for limited participant responses and are, therefore, of little use if "depth" is required. On the other hand, unstructured interviews do not reflect any preconceived theories or ideas and are performed with little or no organisation (May, 1991).

Unstructured interviews are not rigid, and more like a conversation e.g. a descriptive question is asked at the beginning and the interview follows from there based on the initial response. One of the main disadvantages is that semi-structured interviews and interviews, in general, are time- 
consuming. They can be difficult to manage due to the lack of structure, leading to many participants feeling confused. "Their use is, therefore, only considered when depth is required, or where virtually nothing is known about the subject area (or a different perspective of a known subject area is required)" (Gill et al., 2008, p. 291).

Semi-structured interviews are most helpful where a theme is being explored, and the conversation helps to define the areas to be examined. It also allows the interviewer or interviewee to diverge to pursue an idea or response in more detail (Britten, 2007). According to Gill et al. (2008, p. 292) "The flexibility of this approach, particularly compared to structured interviews, also allows for the discovery or elaboration of information that is important to participants but may not have previously been thought of as pertinent by the research team". Disadvantages include: bias due to poor questions, response bias (giving misleading answers for various reasons such as social acceptability), incomplete recollection and reflexivity - interviewee expresses what interviewer wants to hear (Lavrakas, 2008).

For this study, the general research question asked was:

What are the ways community energy can work in an urban scenario in Ontario, specifically Toronto? Furthermore, feedback on the spectrum of community participation in local community energy projects was solicited in the interviews. Finally, the interviewees were asked to provide feedback on a draft version of the questionnaire. Table 3.1 below summarizes how the interview questions were used in the research: 
Table 3.1 Interview questions and subsequent use in current research

\begin{tabular}{|c|c|}
\hline Interview question & Research purpose \\
\hline $\begin{array}{c}\text { What is your definition and understanding } \\
\text { of the phrase "community energy"? Can it } \\
\text { manifest in the urban centers of the world? } \\
\text { Why? Why not? }\end{array}$ & $\begin{array}{c}\text { Explore the meaning of community energy } \\
\text { and its urban implications with experts in the } \\
\text { areas of community energy, urban energy } \\
\text { production, }\end{array}$ \\
\hline $\begin{array}{c}\text { Which of these are most likely to happen in } \\
\text { Toronto (or other urban centers in } \\
\text { Ontario)? Why/why not? }\end{array}$ & $\begin{array}{c}\text { Compare and contrast with a similar question } \\
\text { asked from residents in Toronto. } \\
\text { Validate spectrum of energy model with } \\
\text { experts. }\end{array}$ \\
\hline $\begin{array}{c}\text { What is your feedback on the proposed } \\
\text { questionnaire? }\end{array}$ & $\begin{array}{c}\text { Validate the questions in the survey with } \\
\text { other experts in the field. }\end{array}$ \\
\hline
\end{tabular}

Selecting research participants and recruitment: The researcher has deep knowledge of the Ontario energy landscape having worked in it for the past 5 years at various organisations such as the Centre for Urban Energy at Ryerson University and the Advanced Energy Centre at MaRS Discovery District. This has provided the researcher with an understanding of the sector as well as industry stakeholders. This understanding was relied upon to identify initial participants for the research. Furthermore, a snowball sampling method was used to determine the number of participants and the kinds of participants based on earlier participant suggestions. Snowball sampling is beneficial where there is no obvious list of the population, as is in the case of the current research (Sharma, 2017). Identifying a comprehensive list of experts in the areas of urban community energy, community energy and citizen participation was difficult and it was expected that experts would know others in the same field. Thus, snowball sampling was considered ideal for the current research. Disadvantages of snowball sampling arise when the data collected is quantitative and analysed statistically. It is not possible to determine sampling error when using snowball sampling (Sharma, 2017). Therefore, in the present study, the qualitative data collected through the interviews, where participants are selected through snowball sampling, avoided 
sampling error that could be significant to the final results. However, there might be bias so the researcher tried to overcome this by interviewing people from different community energy related sectors such as government, academia, and industry and so on. All interview participants were recruited via email and a list of such participants can be found in Appendix B.

\section{Phase II: Survey}

The term 'survey' is applied to a research methodology designed to collect data from a particular population or a sample from that population, and typically utilises a questionnaire or an interview as the survey instrument (Robson, 1993). Following the semi-structured interviews, the survey method was used in the present study to provide a quantitative analysis of the level of interest, specific motivations, identification of descriptive characteristics, and modal choices that might influence participation in urban community energy projects. Surveys were specifically used in this study to solicit responses to the behavioural motivation of participants, along with their preferred level of participation in local community energy projects. Groves et al. (2013) advocate questionnaires and states that there are advantages in using a questionnaire vs. an interview methodology as questionnaires are less expensive and easier to administer than interviews, which tend to be time-consuming. Questionnaires are better for larger groups, and they allow confidentiality to be assured. Couper (2008) indicates that online surveys are enormously efficient at providing data in a relatively brief period at a low cost to the researcher.

The survey process is however quite extensive and required careful planning and resource allocation, especially time. Therefore, it was unrealistic, given time and cost restraints, to have indepth semi-structured interviews with a vast number of respondents. Thus, a questionnaire suited the population better and helped answer the important research questions. Figure 3.3 depicts the various stages involved in conducting the survey. 


\section{Designing \\ survey \\ process
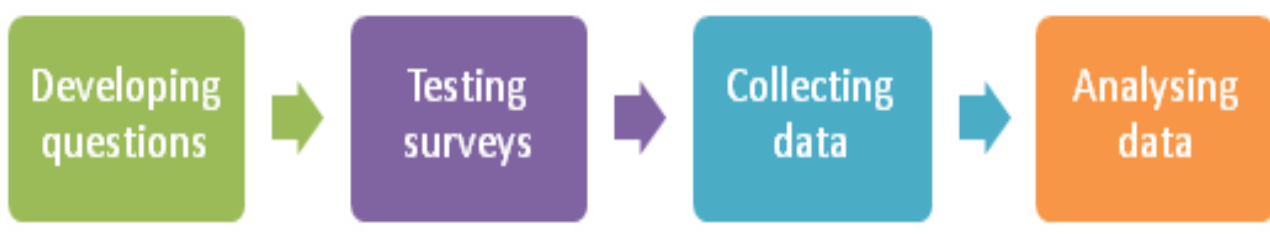

Figure 3.3 - Stages involved in survey

\section{Designing the survey process}

Listed below are the four major considerations when designing surveys.

- Goals: The goals of these surveys would be to understand if the stakeholders are interested in collaborative ownership and management of community energy projects and what would motivate their willingness to participate. It will also aim to understand if different forms of collaborative ownership and management models can influence community members participating in local community energy projects.

- Target population and sample size: The survey was sent to residents of Toronto, as the target urban population. Toronto was chosen as a prime example of an urban centre in Ontario. It provided ease of access to the researcher who resided there during the time of the data collection Furthermore, as Toronto is serviced by one utility, Toronto Hydro, it generally controls for the same level of service being provided to residents. The current research focused on consumers of energy and not only customers, as that would exclude sections of the society who are not responsible for paying their hydro bills e.g. renters with utility included rent.

An online sample calculator was used to determine the optimum sample size required to achieve a $95 \%$ confidence level with a confidence interval of $+/-5 \%$. Based on the population of the City of Toronto (2.73 million) the ideal sample size required to achieve required confidence level and intervals is 328 . The researcher aimed for this number, but was only able to collect 281 responses, of which some were incomplete. A total of 267 responses were finally used for the SPSS data 
analysis. With a sample of 267 , the confidence interval was $+/-6 \%$ at a $95 \%$ confidence level. Further data collection was restricted due to resource constraints of time and money. The survey was limited to households and so it could be argued that the sample population was measured households suggesting a smaller population i.e. number of households instead of population and as such a more generalizable sample size was used in this research.

- $\quad$ Timing: Timing is crucial to proper data collection. Since the surveys require an ethics clearance, proper time allotment for survey development, ethics clearance and pilots were done.

- $\quad$ Mode: There are various methods of conducting surveys. The mode depends on survey population, study topic and end goals of the research. For this particular, project the researcher conducted online and in-person questionnaires. Survey Monkey was also used to assist in data collection through digital mediums.

For the questionnaire data collection the sample were residents of Toronto above the age of 18. In order to randomize the sample collection method, the researcher shared the questionnaire through various online social media platforms. Information technology advancements have revolutionized the world, changing how we do business, how we communicate, how we socialize, etc. (Kayam \& Hirsch, 2012). The internet and its impacts on business, society, politics, sport and other areas are heavily researched (Castells, 2002). These new technologies and digital realities have also influenced how researchers are using the internet as a medium for conducting the research, especially for data collection (Kayam \& Hirsch, 2012).

Advantages include:

- Ease of use

- Low costs 


\section{Critique of using the internet to perform data collection}

As Kayam \& Hirsch (2012) describe it, not everyone is on the internet. Thus, using the internet and social media channels exclusively for data collection might lead to leaving out certain sections of society and possibly limiting the representation of the research population.

However, it must be noted that Canada and especially Toronto have some of the highest levels of internet usage in the world, with over $89 \%$ of the population using the internet at least once a day (Statista, 2018). Furthermore, as of the last data available through Statistics Canada from 2011, more than $80 \%$ of Toronto residents use the internet regularly. This number is expected to have risen in the past 8 years; hence, it can be said in the current research that the sample approached through the internet provides a close approximation of the actual population of the country (Statistics Canada, 2019b).

Furthermore, another issue could be self-selection bias, where only participants interested in the topic select to answer the questions. A self-selection bias would lead to biased data, and not a full representation of the views of the residents of Toronto.

In the current study, the questionnaire was shared with Facebook Toronto-based community groups (namely Cityplace, Parkdale, Sutton Village, Junction Triangle, Young Urbanist League, Bunz Helping Zone, among others), through the Toronto-based community listservs and through survey monkey. To capture the views of other people who might not be on the internet, and to avoid self-selection bias to some point, the researcher also visited community events and shared the survey with building management of high-rise buildings in Toronto in order to share among their residents. 


\section{Developing survey questions:}

The questionnaire aimed at exploring the following:

1. Motivations for engaging with local community energy

2. Level of engagement preferred in local community energy

Based on the literature review a model for statistical analysis (Figure 3.4) was derived from the ideas progression and combines the motivations research of Dóci \& Vasileiadou (2015), Balcombe et al. (2013) and Curtius et al., (2018), to identify five main motivations for participation in community energy as shown in Figure 3.4 - Model of Analysis.

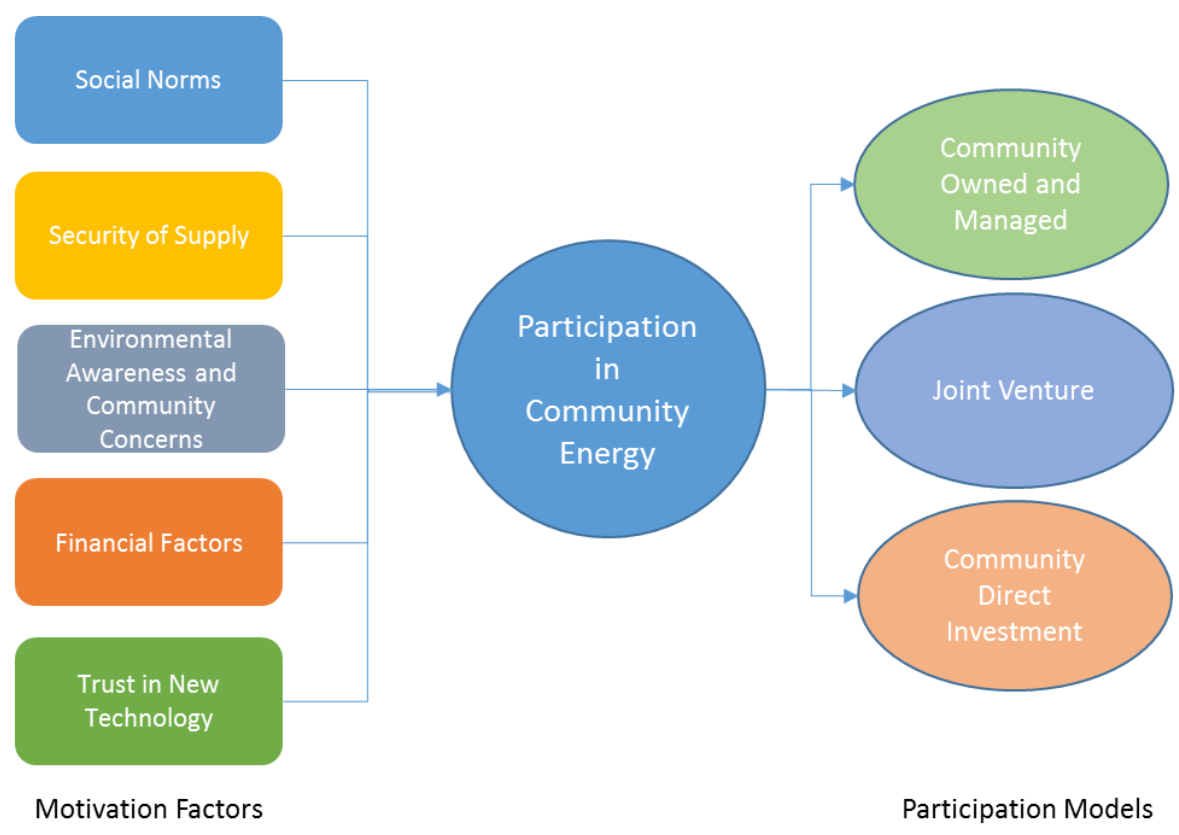

Figure 3.4 - Model of Analysis

Based on the model the questionnaire was developed and modified using interview feedback on the questions provided through the semi-structured interviews. A crucial point raised was about defining what participation meant in terms of community energy projects. The questionnaire was comprised of descriptive and inferential questions related to motivation and participation 
level as summarized in Table 3.2. The descriptive variables in this research describe the sociodemographic characteristics of the sample population answering the questionnaire. Descriptive variables are influenced by the sampling method and the population choice. The inferential variables can be divided into dependent and independent variables. The dependent variables ask questions related to the three models of participation (highlighted in brown). The other variables, which ask questions related to the motivations, are independent variables as part of this research are being measured to determine their respective influence on the dependent variables.

Table 3.2 List of descriptive and inferential variables

\begin{tabular}{|l|}
\hline Descriptive variables \\
\hline Age \\
\hline Building type \\
\hline Ownership \\
\hline Blackout frequency \\
\hline Inferential variables \\
\hline I care about the environment. \\
\hline I have a good understanding of the concept of local community energy \\
\hline I feel strongly attached to the community I live in and I participate in community activities. \\
\hline I would like to support renewable energy produced for local use in my community \\
\hline How likely are you to lead and organise a local community energy project? \\
\hline How likely are you to contribute financially and invest money in a local community energy project? \\
\hline My ideal level of participation in a local community energy project is \\
\hline $\begin{array}{l}\text { How interested are you in owning a part of (such as few solar panels in a solar farm) a bigger local community } \\
\text { energy project led by a developer? }\end{array}$ \\
\hline How likely are you to produce energy and sell it to your neighbour? \\
\hline How likely are you to buy energy from your neighbour/local community energy project? \\
\hline $\begin{array}{l}\text { How likely are you to buy energy from a local community energy project or your neighbour even if it were more } \\
\text { expensive than utility provided electricity? }\end{array}$ \\
\hline $\begin{array}{l}\text { How likely are you to participate in a local community energy project if your neighbours/friends are } \\
\text { participating? }\end{array}$ \\
\hline How likely are you to invest in local energy generation (such as solar panels) if it increases property value? \\
\hline $\begin{array}{l}\text { How likely are you to invest in local generation (such as through solar panels) to reduce outages or have power } \\
\text { during/after an extreme weather event? }\end{array}$ \\
\hline How likely are you to trust and adopt new energy generation technologies? \\
\hline How likely are you to adopt renewable energy technologies such as solar panel in the next 5 years? \\
\hline How many of your neighbours friends and acquaintances have installed a local energy generation system? \\
\hline $\begin{array}{l}\text { I believe that most of my friends and acquaintances expect that I will adopt renewable energy technologies (e.g. } \\
\text { solar panels) within the next } 5 \text { years }\end{array}$ \\
\hline
\end{tabular}




\section{Data Analysis}

A total of 10 experts from industry, academia, government and practitioners of community energy were interviewed to gather a nuanced understanding of the concept of community energy as it could manifest itself in an urban context. A thematic analysis was performed on the qualitative data collected. Thematic analysis (TA) is a qualitative data analysis method widely used by researchers in social sciences (Boyatzis, 1998). TA is used to find underlying themes in data. The researcher re-read the data and familiarized herself with it, finding repetitive information and noting them down. These were then identified into broader themes. While a snowball sampling approach was applied to provide for a reasonable number of interviewees, a qualitative sample of 10 with only three principle questions meant that the TA process was not overly in-depth.

The questionnaire data were analysed quantitatively. The questionnaire response sample size $\mathrm{n}=270$ was analysed in SPSS, a leading quantitative statistical analysis software used beyond social sciences now for handling of large data sets for machine learning purposes.

Before running SPSS, some characterizations were made about the data. Descriptive variables evaluated the impacts of age, gender, building type, building ownership and blackouts on motivation and the likelihood of participation in local community energy projects. The descriptive data is nominal in nature. The ordinal data derived from questions using a 7-point Likert scale represent the inferential variables. The inferential variable data can be considered continuous if the assumptions of normality are met and thus further analysis with a parametric procedure can then be followed (Allen and Seaman, 2007). Accordingly, before further analysis, the data was tested for normality. 


\section{Normality of data}

One of the assumptions for most parametric tests to be reliable is that the data are approximately normally distributed. The normal distribution peaks in the middle and is symmetrical about the mean. However, data does not need to be perfectly normally distributed for the tests to be reliable. In this research, the normality of the data were tested through histograms and Q-Q plots (See Appendix A: Test of Normality Results).

\section{Correlations}

A correlation test was run on the data. Spearman's correlation was used in the current study, as the data was treated as both parametric (inferential variables) and non-parametric (descriptive variables). Correlations are important to measure the strength and direction of relation between descriptive and inferential variables. The spearman's correlation co-efficient (called the rho) is used to determine the impact of the various descriptive variables, such as age, building ownership, building type and blackout frequency on motivations to participate in different forms of local community energy projects.

\section{Factor Analysis}

Factor analysis is used as a statistical data reduction and subsequent analysis method that aims to describe correlations among multiple variables, providing an underlying common explanation or factor. According to Thompson (2007, abstract), there are three main purposes for using factor analysis. "(1) empirically creating a theory of structure (e.g., Cattell's Structure of Intellect model), (2) evaluating whether factored entities (e.g., variables) cluster in a theoretically expected way (e.g., construct validity evaluation), and (3) estimating latent variables scores (i.e., factor scores) that are then used in subsequent statistical analyses (e.g., MANOVA, descriptive discriminant analysis) in place of the measured factored entities (e.g., variables)". 
There are two main conditions necessary for factor analysis and principal components analysis. The first is that there needs to be relationships among the variables. Further, the larger the sample size, especially in relation to the number of variables, the more reliable the resulting factors. Sample size is less crucial for factor analysis to the extent that the communalities of items with the other items are high, or at least relatively high and variable. Ordinary principal axis factor analysis should never be done if the number of items/variables is greater than the number of participants (Leech et al., 2014). The Rotated Factor Matrix table is key for understanding the results of the analysis. Factors are rotated so that they are easier to interpret. Rotation makes it so that, as much as possible, different items are explained or predicted by different underlying factors, and each factor explains more than one item (Osborne, 2015). After the factor analysis, multiple regression was conducted.

\section{Regression analysis}

After the factor analysis, a series of regression analyses were carried out using those inferential variables that factored into the four different factors as identified later in Section 5 - Results and Discussion. Multiple regression, an extension of linear regression, was used to understand preferences for local, community and renewable energy and how they can be predicted based on socio-economic factors. It estimates models that describe the distribution of a dependent variable with the help of a number of predictive (independent) variables and functions to examine how various predictive variables influence (causality) any significant variation in the dependent variable. ${ }^{4}$ There are three main dependent variables corresponding to the three models of participation as described earlier: community led and managed, joint venture, and community direct investment. Questions pertaining to these three models form the dependent variable and as

\footnotetext{
${ }^{4}$ https://astro.temple.edu/ jagbir/regression2.pdf
} 
the responses were based on an expanded 7-point Likert scale they were treated as continuous. ${ }^{5}$ As such, multiple regression was used as opposed to other regression methods such as ordinal logistic (e.g. dependent variable measured on 3 point Likert scale) or probit/logit (binary dependent variables). ${ }^{6}$ The independent variables ask questions about the various motivating factors, which are then tested against the dependent variables in the regression analysis to see the levels of causality between them. As described earlier, multiple-regression allows for determination of the overall fit (variance explained) of the model and the relative contribution of each of the predictors to the total variance explained. Furthermore, stepwise regression was conducted, where order of importance of the different variables in the regression are evaluated. After each step in which a variable was added, all variables in the model are checked to see if their significance has been reduced below the specified tolerance level. Non-significant variables are removed from the model. A final model with significant variables is then produced. ${ }^{7}$ Variance Inflation Factors (VIF) measure was undertaken to address how much the variances of the estimated regression coefficients are inflated as compared to when the predictor variables are not linearly related in order to test whether there is multicollinearity (correlation between predictors) in the regression analysis.

\footnotetext{
${ }^{5} \mathrm{https}: / / \mathrm{www}$. statisticssolutions.com/can-an-ordinal-likert-scale-be-a-continuous-variable/

${ }^{6}$ https://are.berkeley.edu/courses/EEP118/fall2010/section/13/Section\%2013\%20Handout\%20Solved.pdf

${ }^{7}$ http://www.geog.leeds.ac.uk/courses/other/statistics/spss/stepwise/
} 


\section{Results and Discussion}

The qualitative information gathered through the semi-structured interviews were analysed for broader themes. Data collected from 10 interview participants were included in the TA, and the TA was conducted only for the first two questions, as question three dealt with a review of the questionnaire and changes were made to the questionnaire based on the suggestions from the interview, such as providing more clarity to different terms such as community energy participation. Some of the common themes identified from the TA were:

Community benefit: There was a recognition that community energy should provide benefits to the community and that the term not be diluted by projects that did not prioritize benefits to the community through local generation.

Lack of information for practitioners: It was identified that there was not a lot of information available for how Ontario residents could engage together to create community energy projects. Information around processes, permits, and resources with planning help are often considered important to the creation of a community energy project.

For question number two, where the level of participation-related question was asked, most respondents agreed that medium to low levels of participation would be found for most residents of urban centres. It was also suggested that since residents of Toronto had experience working with the utility on conservation and demand management programs, there might be a relationship built to develop community energy projects in a similar participation model if it were being led by the utility.

Quantitative data were analysed statistically. The first few questions in the questionnaire were descriptive variables, which asked respondents their age, ownership versus rent, type of building and blackout frequency. Most respondents were between the ages of 18 and 35, closely followed 
by respondents between ages of 35 and 64 (Figure 5.1). According to the last census data, this closely mirrors the demographic breakdown in Toronto where over $68 \%$ of the population is between the ages of 19 and 64 . As the current study only included persons of age 18 years or abo ve, the demographics breakdown of the respondent's matches with that of the residents of the city (Statistics Canada, 2019c). The low numbers for above 65 years old can be also explained by the use of the internet for data collection, as many older people are not regular users of the internet.

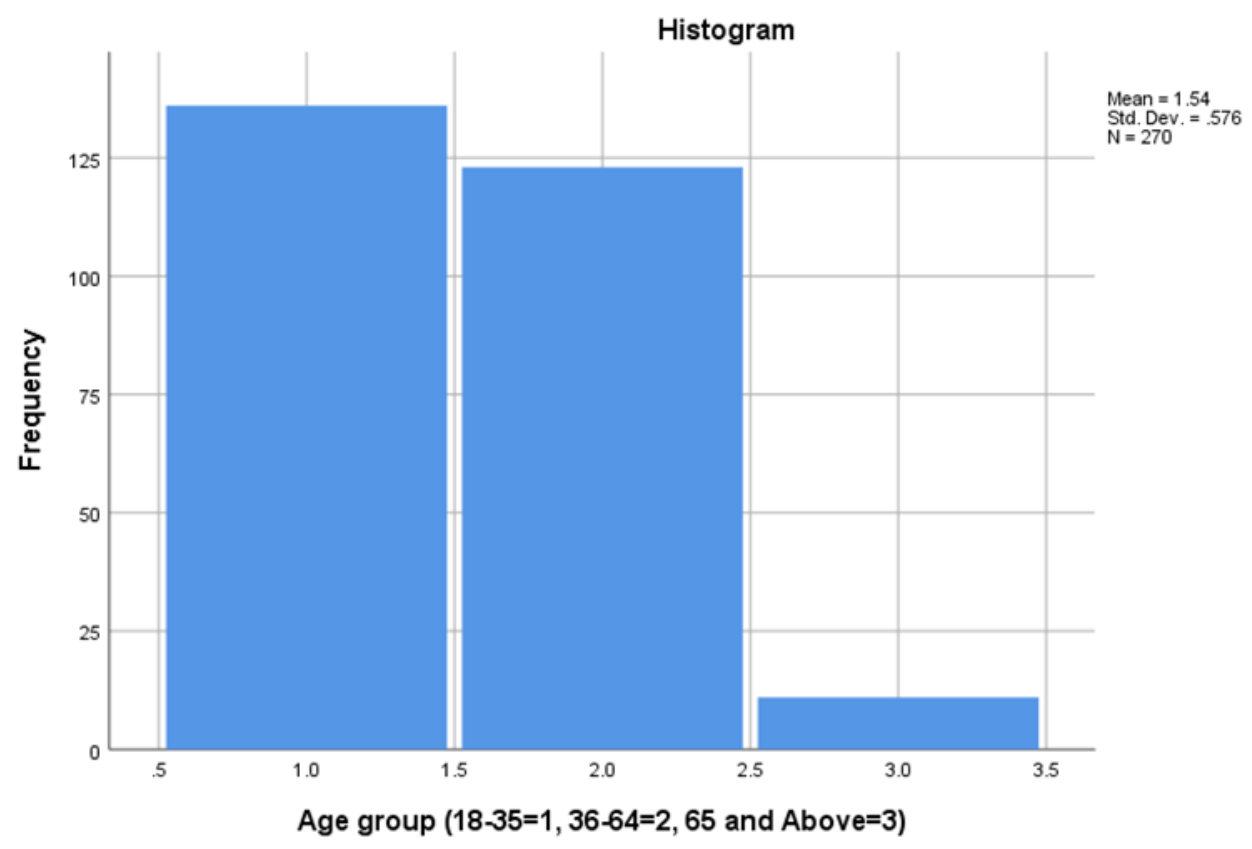

Figure 5.1 Distribution of respondents by age

When it comes to ownership and dwelling type, 53\% of the respondents lived in houses and $47 \%$ lived in apartments/condominiums. $66 \%$ of the respondents owned their place of residence while the others are tenants (Figure 5.2). This data distribution can be explained possibly through selfselection by respondents where owners and house dwellers, who have a higher interest in adoption of renewable energy, could have been more interested in answering the questionnaire, as opposed to tenants in apartments, who would have fewer incentives for local community energy generation. 


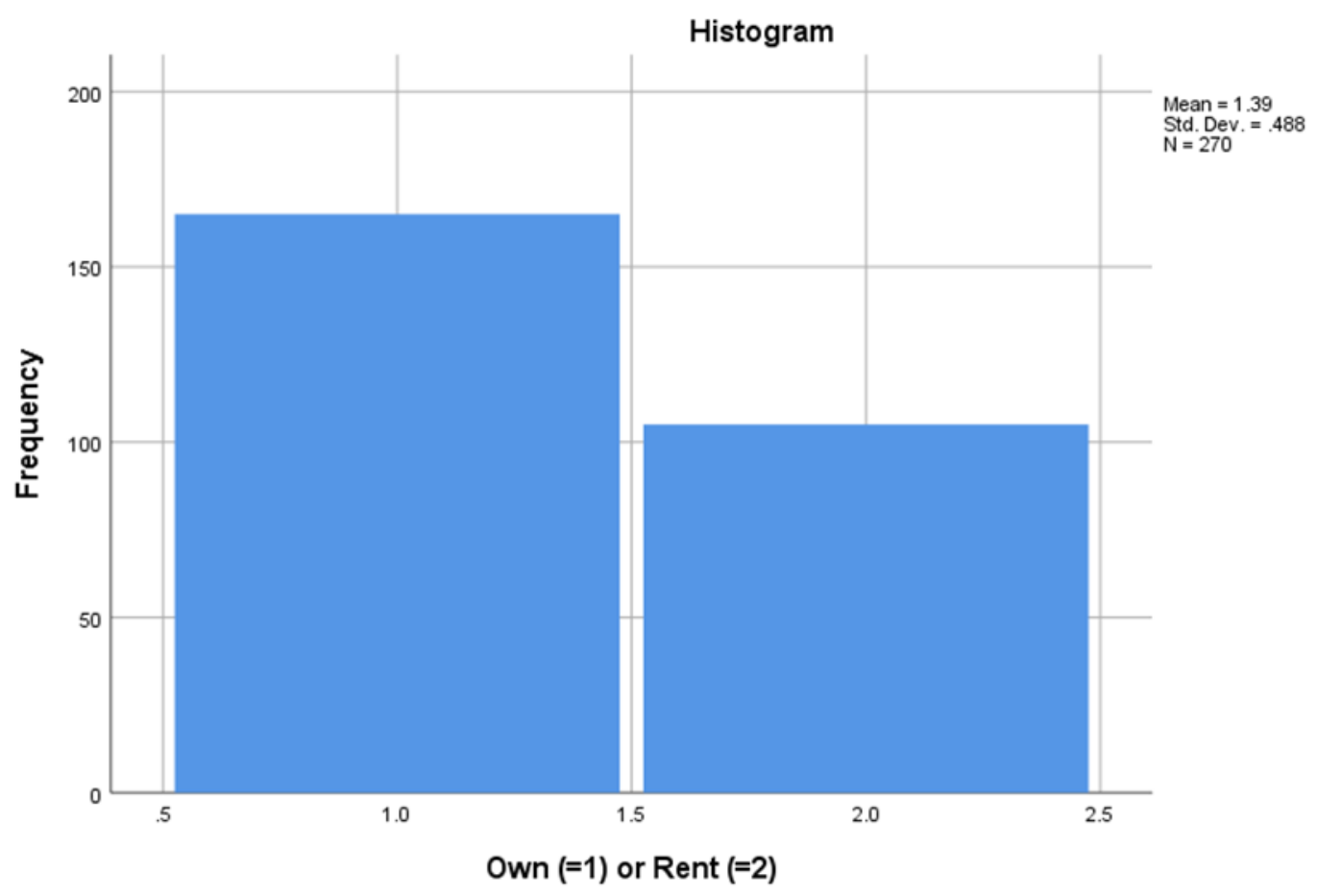

Figure 5.2 Distribution of respondents by ownership versus rental

When asked about whether they cared for the environment, most respondents answered 5 or above (on a scale of 1-7, where I: strongly disagree and 7: strongly agree) (Figure 5.3). Most respondents indicated they also had a high level of understanding of the concepts of community energy (Mean=4.7, SD=1.39, $\mathrm{n}=270$ ). The researcher expects this high score to be a reflection of two factors: that the concept of community energy was described in the preamble to the questionnaire, to provide the respondents with a common understanding of the term, as it pertains to the research, and that in Ontario there has been noticeable discussion of electricity and community energy in the media since the introduction of the Green Energy Act and over the years residents of Ontario have had a higher level of exposure to the topics of energy, electricity systems, community renewable energy and so on. 


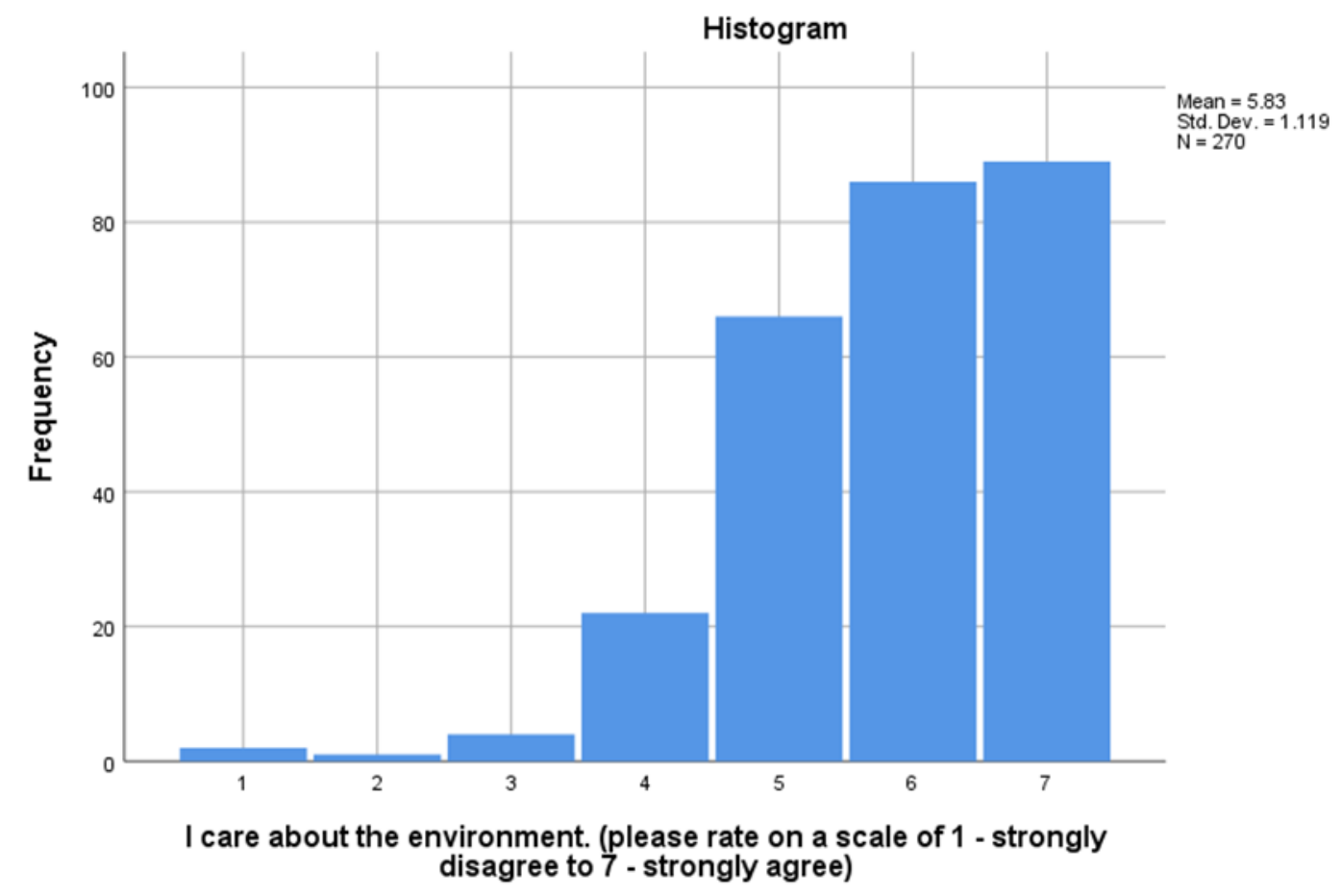

Figure 5.3 Distribution of respondents by their level of care for the environment

When asked if they felt a connection to their community, most respondents indicated a high level of connection to their community (Mean=4.91, $\mathrm{SD}=1.423, \mathrm{n}=270$ ). Most respondents were also in favour of local generation and usage of energy in their community using renewable sources (Mean=5.52, SD=1.23, $\mathrm{n}=270$ ). However, when asked if they would like to lead or organise a community energy project, many respondents had no or low levels of interest in doing so (Mean=3.81, SD=1.86, $\mathrm{n}=270$ ). More people were interested in investing in them financially (Mean=4.01, $\mathrm{SD}=1.79, \mathrm{n}=270$ ), than in leading or organising one.

One of the main results from this current research pertains to participation levels preferred by residents of Toronto. From the questionnaire, most respondents have indicated that they prefer a low to medium level of participation in community energy projects. This data distribution is represented in Figure 5.4. 


\section{Toronto residents' referred level of participation in local community energy projects $(n=281)$}

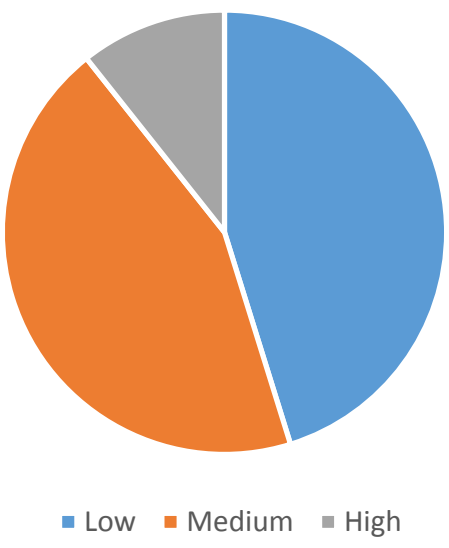

Figure 5.4 Participation preference data from Toronto

This is consistent with the predictions/expert opinions provided in the semi-structured interviews of experts and practitioners in the community energy sector. One respondent identified that since urban residents already have experience in collaborating with their utility for conservation demand management programs, partnerships where an expert handles the technical aspects, would be best suited for urban residents. Further notes from the interviews can be found in Appendix B: Semistructured Interviews Highlights. These results are consistent with some of the literature on the topic, which shows that while people support local and renewable energy generation, not everyone wants to be involved in them at high-levels of participation (St. Denis \& Parker, 2009; Bauwens, 2016).

Another finding that corresponds with the literature is that many show concern for the environment but that does not translate into paying more for environmental options (Walters \& Walsh, 2011; Balcombe et al., 2013). Hence, while the majority of respondents replied that they care for the environment and would support local community generation projects in their own communities, 
few actually said they were likely to buy locally generated renewable electricity if it were more expensive than utility provided rates (Figure 5.5).

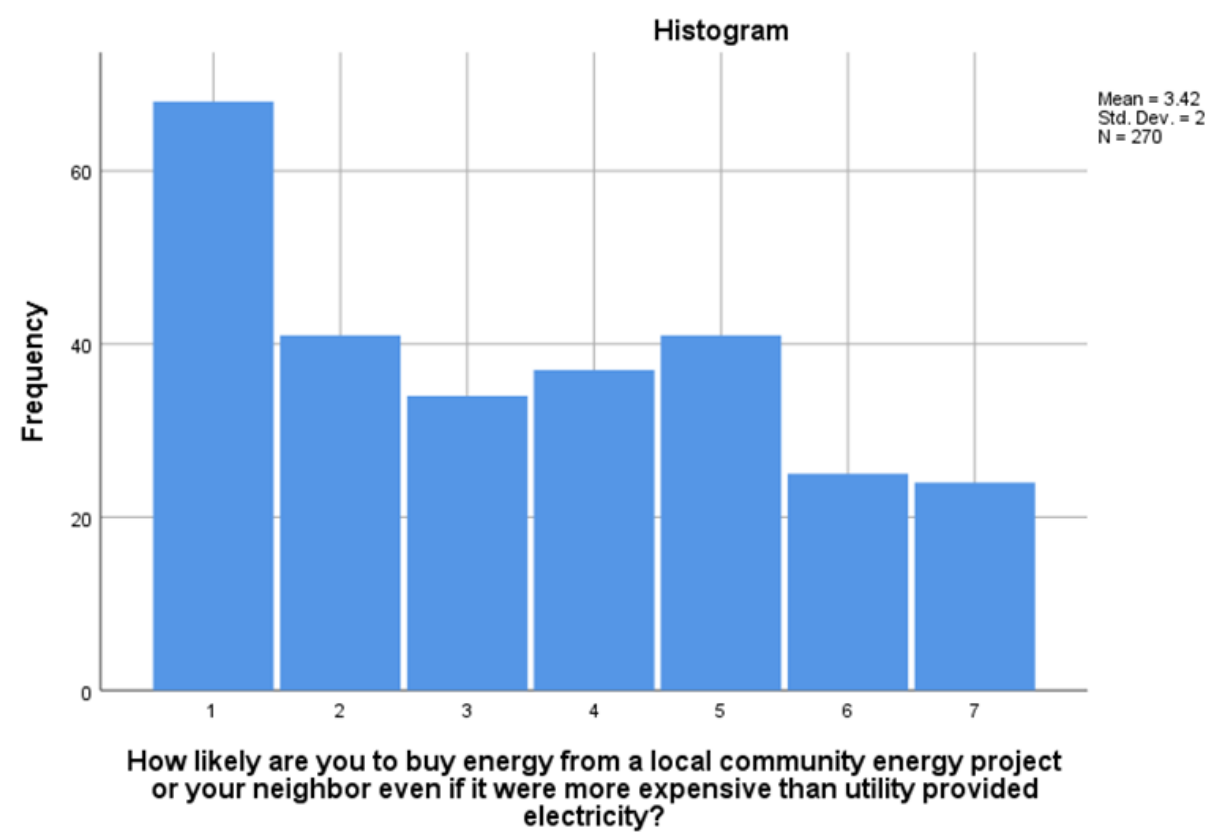

Figure 5.5 Distribution of responses to more expensive community renewable energy project

Furthermore, respondents indicated a high level of concern for local community energy projects affecting property value (Mean=4.83, $\mathrm{SD}=1.72, \mathrm{n}=270)$. Respondents were also interested in community energy for reducing weather related outages (Figure 5.6).

For the questions that pertained to social norms, respondents indicated that they would participate in local community energy projects, if their friends and family were participating (Mean=4.65, $\mathrm{SD}=1.64, \mathrm{n}=270$ ). However, it was interesting to note that respondents indicated that very few of their friends and neighbours actually participated in local generation (Mean=2.72, SD=1.71, $\mathrm{n}=270$ ), or expected them to participate in local community energy projects or self-generation 
(Mean=3.36, $\mathrm{SD}=1.82, \mathrm{n}=270)$. In Toronto, very few local generation and local community energy generation projects exist, so it is not surprising to find these statistics.

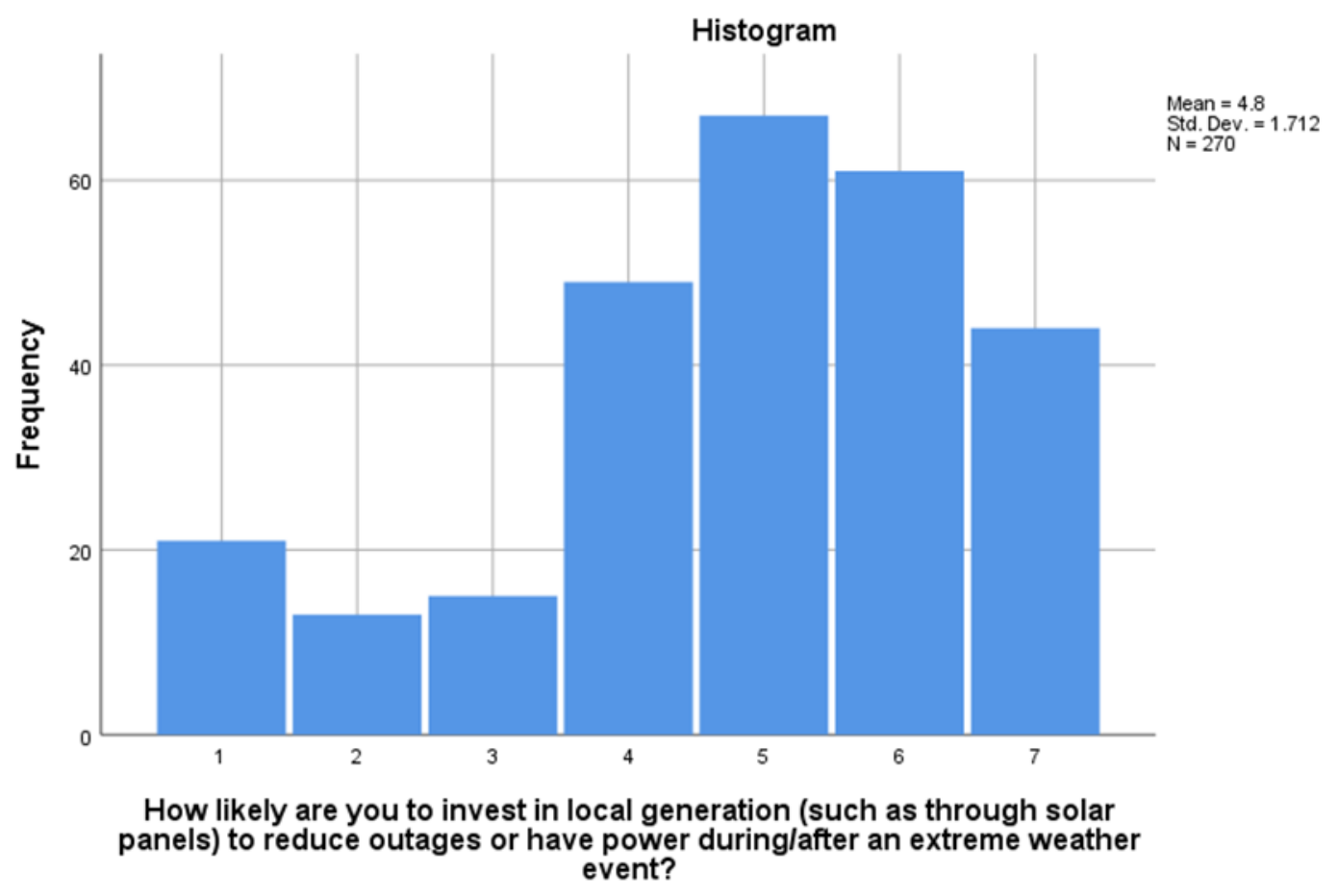

Figure 5.6 Responses to investment for security of supply issues

\section{Correlation of Descriptive Variables with Inferential Variables (Dependent and Independent):}

A correlation study was conducted using Spearman rho correlation to examine if the descriptive variables have statistically significant monotonic associations with any of the inferential variables, dependent or otherwise. This method of correlation was deemed suitable for the current dataset, as Spearman requires that each variable be measured on the nominal or ordinal scale. The Spearman's rank-order correlation is the non-parametric version of the Pearson correlation. Spearman's correlation coefficient, ( $\rho$, also signified by $r_{\mathrm{s}}$ ) measures the strength and direction of association between two ranked variables. 
Tables 5.1 and 5.2 identify correlation coefficients (R) and their significance (p). Only values where the strength of association is greater than .200 correlation coefficient (moderate strength of associate or greater) along with $\mathrm{p}<.01$ or $<.001$ are considered of significant importance.

Age

As can be seen, age shows weak to moderate correlations with most of the inferential variables, it correlated with variables describing participation as well as behavioural motivations. Balcombe et al. (2013) describe an inverted ' $U$ ' model of correlation between age and adoption of local generation, adoption reduced with younger and older respondents whereas middle-aged people are more likely adopters, until their retirement. Financial factors related to local generation technology adoption are likely influencers in this case.

\section{Building type and ownership}

Building type has been identified as significantly correlated with adoption of local generation and more single house owners adopt local generation systems. Ownership is crucial as people feel more empowered when they own their dwelling to make financial decisions related to local community energy. Furthermore, owners are also more concerned about property prices and that factors into their decision for adoption of local generation

\section{Blackouts}

The respondents were asked how many times they faced blackouts in a year. The data indicated most people in Toronto faces low incident of blackouts. This is supported by the fact that Toronto is considered a most resilient city and when compared to outages elsewhere, shows that Toronto's grid has high levels of recovery within a few hours. This is supported by the SAIFI, SAIDI \& CAIDI numbers for Toronto Hydro, which are above average, indicating a reliable system with low blackouts as shown in Table 5.3. 
Table 5.1 Statistically Significant Correlations $p<.05$

\begin{tabular}{|c|c|c|c|c|c|c|c|c|c|c|}
\hline & & Q1 & Q2 & Q3 & Q4 & Q5 & Q6 & Q7 & Q8 & Q9 \\
\hline \multirow{2}{*}{ Age group } & $\mathrm{CC}$ & & & & & $-.138^{*}$ & $-.200^{* * *}$ & $-.197^{* *}$ & $-.139^{*}$ & $-.190^{* *}$ \\
\hline & Sig. (2-tailed) & & & & & 0.021 & 0.001 & 0.001 & 0.021 & 0.002 \\
\hline \multirow{2}{*}{ Own } & $\mathrm{CC}$ & & & $-.139^{*}$ & & & & $-.118^{*}$ & $-.132^{*}$ & \\
\hline & Sig. (2-tailed) & & & 0.019 & & & & 0.049 & 0.028 & \\
\hline \multirow{2}{*}{ Building Type } & $\mathrm{CC}$ & $-.130^{*}$ & & $-.193^{* *}$ & $.196^{-}$ & $.133^{*}$ & & & & \\
\hline & Sig. (2-tailed) & 0.029 & & 0.001 & 0.001 & 0.027 & & & & \\
\hline \multirow{2}{*}{$\begin{array}{l}\text { Blackout } \\
\text { Frequency }\end{array}$} & $\mathrm{CC}$ & & & & & $.163^{* *}$ & & & & \\
\hline & Sig. (2-tailed) & & & & & 0.006 & & & & \\
\hline
\end{tabular}

Q1. I care about the environment.

Q2. I have a good understanding of the concept of local community energy

Q3. I feel strongly attached to the community I live in and I participate in community activities.

Q4. I would like to support renewable energy produced for local use in my community

Q5. How likely are you to lead and organise a local community energy project?

Q6. How likely are you to contribute financially and invest money in a local community energy project?

Q7. My ideal level of participation in a local community energy project is

Q8. How interested are you in owning a part of (such as few solar panels in a solar farm) a bigger local community energy project led by a developer?

Q9. How likely are you to produce energy and sell it to your neighbour? 
Table 5.2 Statistically Significant Correlations $p<.05$ (Continued)

\begin{tabular}{|c|c|c|c|c|c|c|c|c|c|c|}
\hline & & Q10 & Q11 & Q12 & Q13 & Q14 & Q15 & Q16 & Q17 & Q18 \\
\hline \multirow{2}{*}{ Age group } & $\mathrm{CC}$ & & & & $-.166^{* *}$ & $-.139^{*}$ & $-.133^{*}$ & $-.161^{* *}$ & $-.226^{* *}$ & $-.213^{* *}$ \\
\hline & Sig. (2-tailed) & & & & 0.006 & 0.022 & 0.028 & 0.007 & 0.000 & 0.000 \\
\hline \multirow{2}{*}{ Own } & $\mathrm{CC}$ & & $-.164^{* *}$ & $-.174^{* *}$ & $-.174^{* *}$ & & & & & \\
\hline & Sig. (2-tailed) & & 0.006 & 0.004 & 0.004 & & & & & \\
\hline \multirow{2}{*}{$\begin{array}{l}\text { Building } \\
\text { Type }\end{array}$} & $\mathrm{CC}$ & & $-.184^{* *}$ & & & & & & $.136^{*}$ & \\
\hline & Sig. (2-tailed) & & 0.002 & & & & & & 0.023 & \\
\hline \multirow{2}{*}{$\begin{array}{l}\text { Blackout } \\
\text { Frequency }\end{array}$} & $\mathrm{CC}$ & & & & & & & & $.182^{* *}$ & $.140^{*}$ \\
\hline & Sig. (2-tailed) & & & & & & & & 0.002 & 0.019 \\
\hline
\end{tabular}

Q10. How likely are you to buy energy from your neighbour/local community energy project?

Q11. How likely are you to buy energy from a local community energy project or your neighbour even if it were more expensive than utility provided electricity? Q12. How likely are you to participate in a local community energy project if your neighbours/friends are participating?

Q13. How likely are you to invest in local energy generation (such as solar panels) if it increases property value?

Q14. How likely are you to invest in local generation (such as through solar panels) to reduce outages or have power during/after an extreme weather event?

Q15. How likely are you to trust and adopt new energy generation technologies?

Q16. How likely are you to adopt renewable energy technologies such as solar panel in the next 5 years?

Q17. How many of your neighbours friends and acquaintances have installed a local energy generation system?

Q18. I believe that most of my friends and acquaintances expect that I will adopt renewable energy technologies (e.g. solar panels) within the next 5 year 
Table 5.3 Toronto Hydro Reliability Numbers

\begin{tabular}{|l|l|l|}
\hline Measures & Toronto Hydro (2017) & Average (2016) $^{\mathbf{9}}$ \\
\hline SAIFI (System Average & $1.43 /$ year & $2.78 /$ year \\
\hline SAIDI (System Average & 1 hour & 4.39 \\
Interruption Frequency Index) & & 1.58 \\
\hline CAIDI (Customer Average & .66 & \\
\hline
\end{tabular}

The questionnaire data were further analysed with SPSS, to determine normality. After normality of data was ascertained (Appendix A), principal axis factor analysis with varimax rotation was conducted to assess the underlying structure for the variables of the questionnaire (The assumption of independent sampling was met. The assumptions of normality, linear relationships between pairs of variables, and the variables' being correlated at a moderate level were checked.) There were four factors identified by SPSS after a dimensions reduction principal axis factor analysis was done. The factor analysis identified 4 factors when the number of factors was not specified. These 4 factors (See Table 5.4) can be identified as follows:

- Factor 1: Financial

- Factor 2: Social norms

- Factor 3: Environmental and community

${ }^{8}$ https://www.torontohydro.com/sites/corporate/InvestorRelations/FinancialReports/Financial\%20Report/AIF\%202017.pdf

${ }^{9} \mathrm{https} / / / \mathrm{www}$. torontohydro.com/sites/electricsystem/residential/customercare/Documents/Scorecard\%20-

$\%$ 20Toronto\%20Hydro-Electric\%20System\%20Limited.pdf 


\section{- Factor 4: Uncertainty and trust of technology}

A scree plot (Figure 5.7) provides visual representation of the identification of the four factors when the Eigenvalue is $>1$ since an eigenvalue of 1 represents as much variance as would be associated with a single variable and that only factors that explain at least the same amount of variance as a single variable are retained at $\mathrm{R}>.400$.

\section{Table 5.4 Rotated Component Matrix ${ }^{a}$}

(please rate on a scale of 1 - strongly disagree to 7 -

Factors

strongly agree)

Financial Social norms Env. \& community concern Trust in tech

I care about the environment.

0.723

I have a good understanding of the concept of local community energy

I feel strongly attached to the community I live in and I participate in community activities.

0.717

How likely are you to produce energy and sell it to your neighbour?

How likely are you to buy energy from your neighbour/local community energy project?

How likely are you to buy energy from a local community energy project or your neighbour even if it were more expensive than utility provided electricity? How likely are you to participate in a local community energy project if your neighbours/friends are participating?

How concerned are you about local energy generation (such as solar panels) impacting property value?

0.772

0.793

How likely are you to invest in local generation (such as through solar panels) to reduce outages or have power during/after an extreme weather event?

How likely are you to trust and adopt new energy generation technologies?

0.787

How many of your neighbours friends and acquaintances have installed a local energy generation system?

I believe that most of my friends and acquaintances expect that I will adopt renewable energy technologies 0.840 0.583 (e.g. solar panels) within the next 5 years

Extraction Method: Principal Component Analysis. Rotation Method: Varimax with Kaiser Normalization.

a. Rotation converged in 6 iterations. 


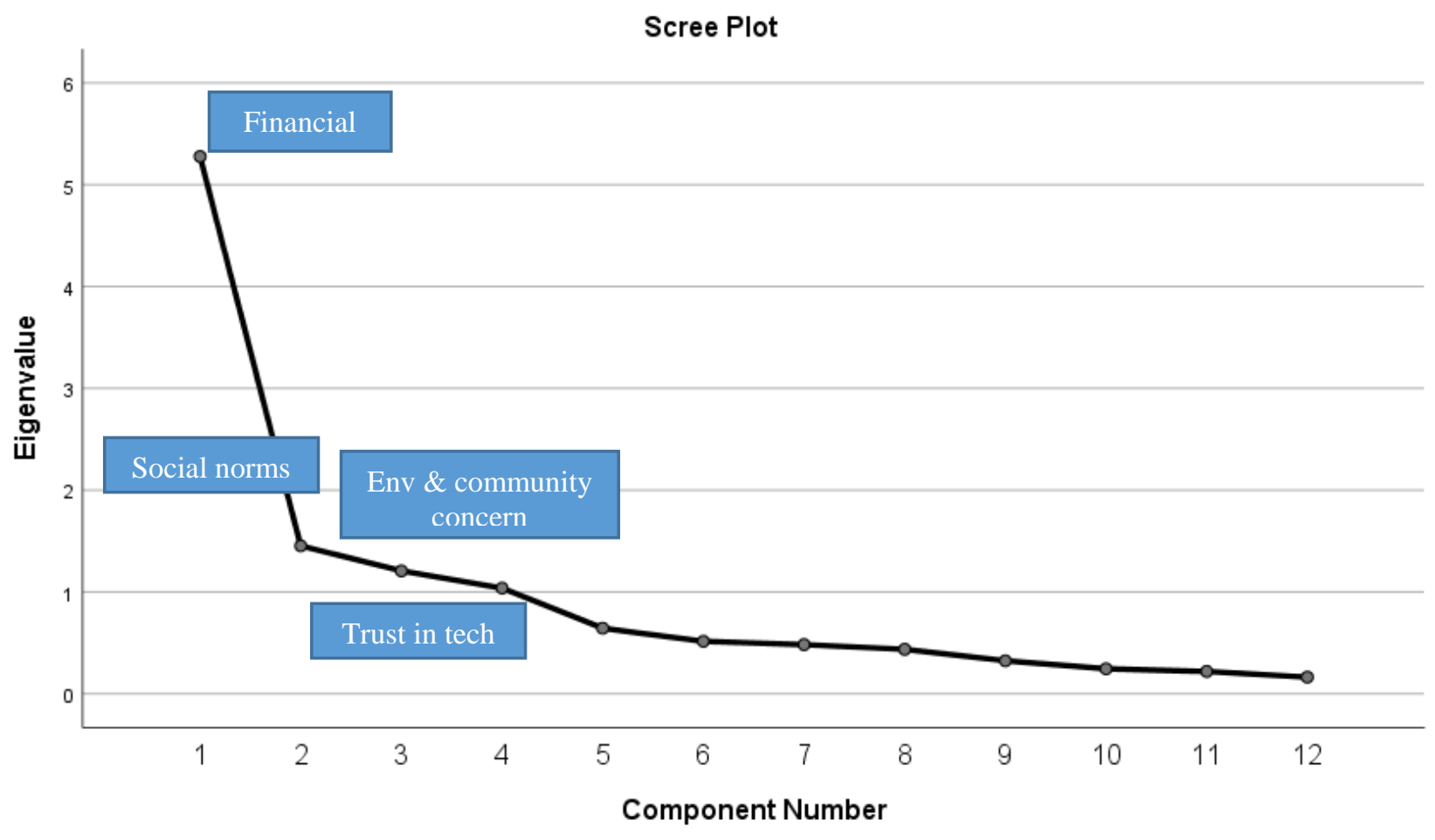

Figure 5.7 Scree plot for principal factor analysis

Given the above factor analysis results, the conceptual model is re-envisioned as described in Figure 5.8. 


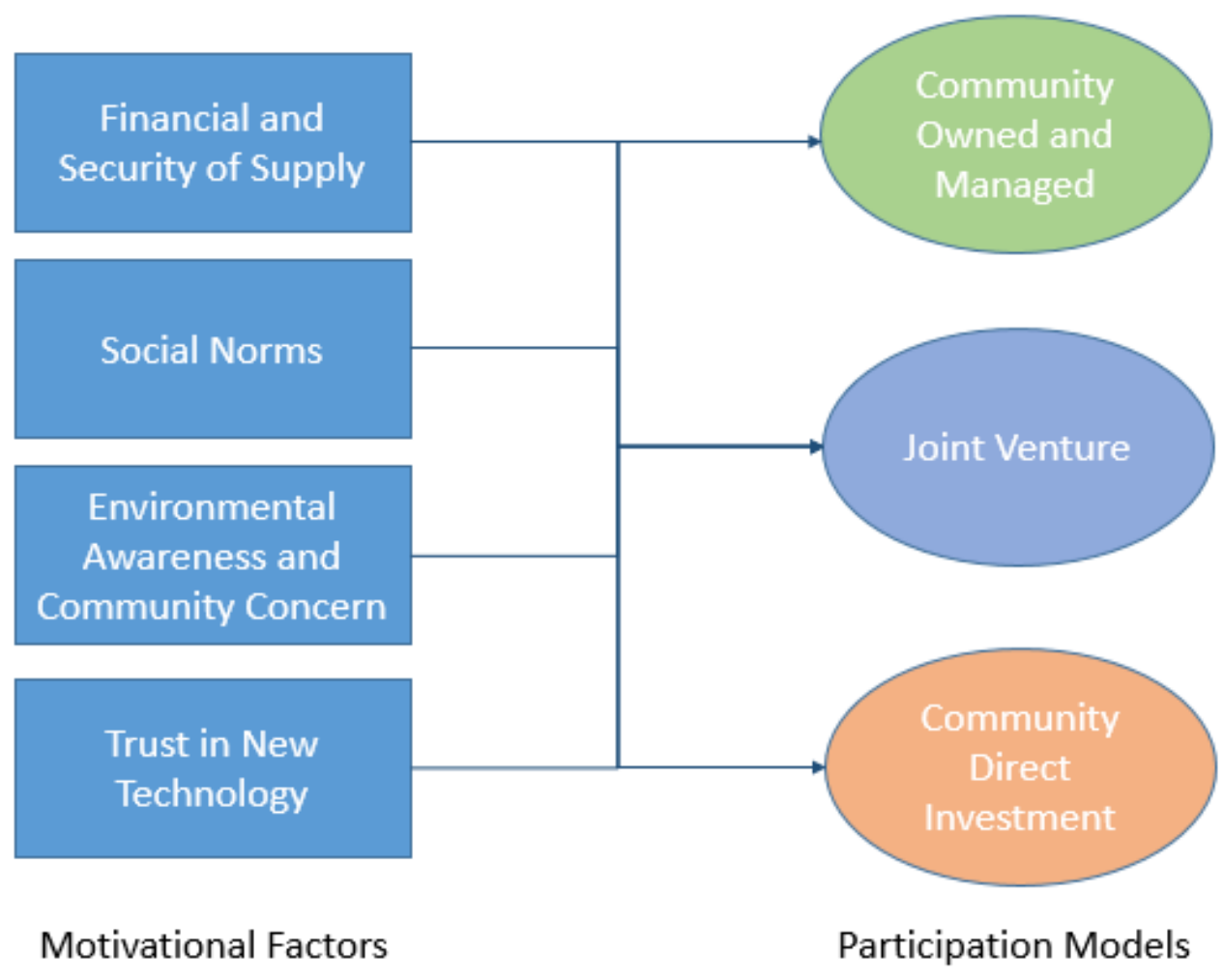

Figure 5.8 Conceptual model of motivational factors and modes of citizen participation through community energy

Relying on the revised model, multiple regression was conducted for each of the three dependant variables and the 4 different factors, as determined by the principal factor/component analysis. The factor analysis was used to group similar variables into smaller number of factors. Moreover, the regression analysis helped to identify statistically the relationship between two or more variables. Here the regression analysis is providing a statistical test of causality of the motivational factors on the willingness to participate in the three possible participation models. This causality is measured by the $\mathrm{R}$ and $\mathrm{R}$-squared values. $\mathrm{R}$ gives a numerical value to describe the correlation between the observed and predicted values of the dependent variable. As we see an increase in the R-squared value with the addition of further variables to the model, the closer the 
model is getting to explaining all the variability in the data. However, every time a new variable is added R-squared increases and hence this value can be artificially increased by using many variables in the model. This is when; the adjusted R-squared is used, which has been adjusted for the number of variables in the model. Therefore, the adjusted R-squared determines if the model with higher number of variables is indeed better.

The regression coefficients are detailed in Appendix D. The VIF number indicates the presence of multi-collinearity (If VIF is near to or above 5) whereby the independent variables exhibit large amounts of inter-correlation between them thus limiting the reliability of the regression results. It can present problems for creating and describing the best model fit for the data present and needs to be avoided. The entire variable set exhibited VIF numbers less than 5, thus the data was deemed to not exhibit multicollinearity. The regression results are described below.

\subsection{Financial and Security of Supply Factor}

Unsurprisingly, the financial factor is of prime concern to Toronto residents who participated in the study and is indicated through the factor analysis and subsequent regression analysis. In the current study, questions around revenue generation from the production and sale of local energy, impact on property value and the security of supply were grouped together under the financial factor. It is especially interesting to note that security of supply has been grouped under this theme when a factor analysis was performed on the dataset. However, in the multiple regression analysis, participation is highly influenced by security of supply. Thus, it is inferred that the respondents to the questionnaire see security of supply from a financial perspective and consider it an important factor while making decisions around energy costs.

As the occurrence of extreme weather events is on the rise, there is increased extreme weather related blackouts being experienced in urban centres (Campbell, 2012; Pantelli \& Mancarella, 
2017). Hence, reliability and resiliency in the face of extreme weather events is increasingly being seen as a driver for the adoption of local generation. However, the financial aspects of backup power through local generation is a critical barrier to adoption of modular generation technologies (Rot et al., 2008; Caird \& Roy, 2012, Balcombe et al., 2013). Thus, it is interesting to note that the variable has been factored into the financial theme.

Security of supply has always been a considerable motivation for humans to act. Securing supply of reliable power is a motivation for adoption of local community generation (Bauwens, 2015). In the statistical analysis, it was found that there is no strong correlation between higher blackouts experienced and the motivation to adopt local energy or self-generation. However, it can be shown in the model that commitment to adopt local generation as a backup is a significant factor associated with the positive views of local community energy. Additionally, it can be hypothesized that security of supply is perhaps a more rural concern and is not a big factor for the city of Toronto, where Toronto Hydro maintains better than average reliability of supply. Hence, due to limited exposure to blackouts, security of supply appears not to be a big concern for this urban sample. Many of the community energy studies have focused on rural projects and hence, the security of supply motivation perhaps applies more in rural versus urban situations.

Regression models (Table 5.5 SPSS data analysis) for the financial factor for the three dependent variables (corresponding to the three participation models), show that revenue generation is important to the respondents (R-value). Other factors of note are security of supply and impact on property value. This creates interesting communication frameworks for community energy projects. For example, a small community organisation trying to create a local bio-waste energy production facility would need to address the revenue generation potential, along with security of supply as major factors to get citizens motivated to participate. Whereas for investing with a 
developer (a term, which will be used in this document as a proxy for $3^{\text {rd }}$ party companies) it is interesting to note that impact on property value becomes an important factor related to increasing the likelihood (as determined by the strength of the explanation of variance $-\Delta \mathrm{R}^{2}$ ) of participation. This suggests that a $3^{\text {rd }}$ party company should ideally not only address revenue generation potential and security of supply but also address the impact on property value.

One explanation could be that there is more trust when something is led by the community versus a $3^{\text {rd }}$ party company when considering how the project would impact property value. Possible ways to overcome this apart from transparency on the issue would be to tie in the property value of the community somehow to the success of the project.

Figure 5.9 below provides a snapshot of the statistical significance of the financial factor for the three different participation models. The $\mathrm{R}$ and adjusted $\mathrm{R}$-squared values indicate the extent to which variables contribute to the model and Table 5.5.

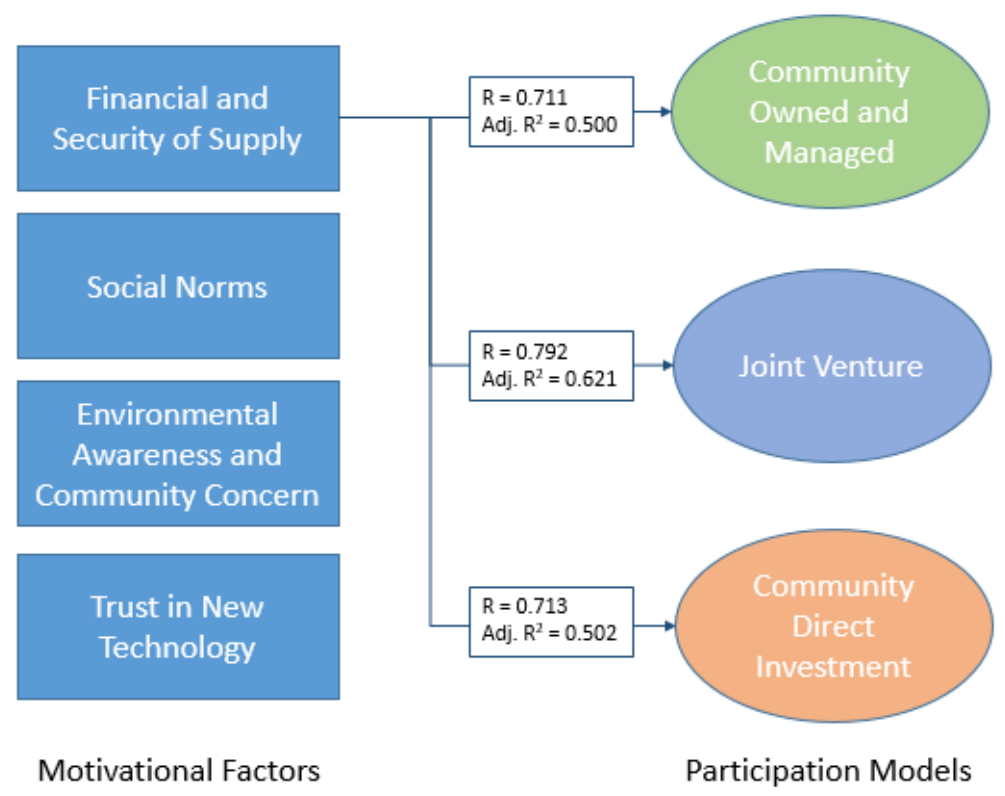

Figure 5.9 Financial factors and models of participation 
The financial factor was examined from the perspective of producing and selling the local energy for a profit, or buying local energy if it were cheaper. Impact on property value was another financial sub-factor that was studied and it proved to be impactful in some models of community energy versus others. The high $R(>.7)$ and $R^{2}(>.5)$ values suggest a strongly significant influence that these financial factors have on the willingness to participate in a community energy project. The impact of these decisions on broader financial questions of stranded assets and understanding whether respondents understood the related financial implication was not carried out in the present study. 
Table 5.5 SPSS data analysis

\section{Community owned and managed}

Model Summary

\begin{tabular}{|c|c|c|c|c|c|c|c|c|c|}
\hline \multirow[b]{2}{*}{ Model } & \multirow[b]{2}{*}{$\mathrm{R}$} & \multirow[b]{2}{*}{ R Square } & \multirow[b]{2}{*}{$\begin{array}{l}\text { Adjusted R } \\
\text { Square }\end{array}$} & \multirow[b]{2}{*}{$\begin{array}{l}\text { Std. Error of } \\
\text { the Estimate }\end{array}$} & \multicolumn{5}{|c|}{ Change Statistics } \\
\hline & & & & & $\begin{array}{l}\mathrm{R} \\
\text { Square } \\
\text { Change }\end{array}$ & $\begin{array}{l}\text { F } \\
\text { Change }\end{array}$ & df1 & df2 & $\begin{array}{l}\text { Sig. F } \\
\text { Chang } \\
\mathrm{e}\end{array}$ \\
\hline 1 & $.620^{\mathrm{a}}$ & 0.384 & 0.382 & 1.464 & 0.384 & 172.212 & 1 & 276 & 0 \\
\hline 2 & $.686^{\mathrm{b}}$ & 0.471 & 0.467 & 1.36 & 0.086 & 44.853 & 1 & 275 & 0 \\
\hline 3 & $.711^{\mathrm{c}}$ & 0.506 & 0.5 & 1.317 & 0.035 & 19.394 & 1 & 274 & 0 \\
\hline
\end{tabular}

a. Predictors: (Constant), How likely are you to produce energy and sell it to your neighbour?

b. Predictors: (Constant), How likely are you to produce energy and sell it to your neighbour? How likely are you to buy energy from a local community energy project or your neighbour even if it were more expensive than utility provided electricity?

c. Predictors: (Constant), How likely are you to produce energy and sell it to your neighbour?, How likely are you to buy energy from a local community energy project or your neighbour even if it were more expensive than utility provided electricity?, How likely are you to invest in local generation (such as through solar panels) to reduce outages or have power during/after an extreme weather event?

d. Dependent Variable: How likely are you to lead and organise a local community energy project?

\section{Joint venture}

Model Summary

\begin{tabular}{|c|c|c|c|c|c|c|c|c|c|}
\hline \multirow[b]{2}{*}{ Model } & \multirow[b]{2}{*}{$\mathrm{R}$} & \multirow[b]{2}{*}{ R Square } & \multirow[b]{2}{*}{$\begin{array}{l}\text { Adjusted R } \\
\text { Square }\end{array}$} & \multirow[b]{2}{*}{$\begin{array}{l}\text { Std. Error of } \\
\text { the Estimate }\end{array}$} & \multicolumn{5}{|c|}{ Change Statistics } \\
\hline & & & & & $\begin{array}{l}\mathrm{R} \\
\text { Square } \\
\text { Change }\end{array}$ & $\begin{array}{l}\text { F } \\
\text { Change }\end{array}$ & df1 & df 2 & $\begin{array}{l}\text { Sig. F } \\
\text { Chang } \\
\mathrm{e}\end{array}$ \\
\hline 1 & $.717^{\mathrm{a}}$ & 0.514 & 0.512 & 1.228 & 0.514 & 291.431 & 1 & 276 & 0 \\
\hline 2 & $.774^{\mathrm{b}}$ & 0.599 & 0.596 & 1.117 & 0.085 & 58.366 & 1 & 275 & 0 \\
\hline 3 & $.787^{\mathrm{c}}$ & 0.62 & 0.616 & 1.089 & 0.021 & 15.246 & 1 & 274 & 0 \\
\hline 4 & $.792^{\mathrm{d}}$ & 0.627 & 0.621 & 1.081 & 0.007 & 4.856 & 1 & 273 & 0.028 \\
\hline
\end{tabular}


a. Predictors: (Constant), How likely are you to invest in local generation (such as through solar panels) to reduce outages or have power during/after an extreme

weather event?

b. Predictors: (Constant), How likely are you to invest in local generation (such as through solar panels) to reduce outages or have power during/after an extreme weather event? How likely are you to produce energy and sell it to your neighbour?

c. Predictors: (Constant), How likely are you to invest in local generation (such as through solar panels) to reduce outages or have power during/after an extreme weather event?, How likely are you to produce energy and sell it to your neighbour?, How likely are you to buy energy from a local community energy project or your neighbour even if it were more expensive than utility provided electricity?

d. Predictors: (Constant), How likely are you to invest in local generation (such as through solar panels) to reduce outages or have power during/after an extreme weather event?, How likely are you to produce energy and sell it to your neighbour?, How likely are you to buy energy from a local community energy project or your neighbour even if it were more expensive than utility provided electricity?, How concerned are you about local energy generation (such as solar panels) impacting property value?

e. Dependent Variable: How interested are you in owning a part of (such as few solar panels in a solar farm) a bigger local community energy project led by a developer?

\section{Community direct investment}

Model Summary ${ }^{\mathrm{e}}$

\begin{tabular}{|c|c|c|c|c|c|c|c|c|c|}
\hline \multirow[b]{2}{*}{ Model } & \multirow[b]{2}{*}{$\mathrm{R}$} & \multirow[b]{2}{*}{ R Square } & \multirow[b]{2}{*}{$\begin{array}{l}\text { Adjusted R } \\
\text { Square }\end{array}$} & \multirow[b]{2}{*}{$\begin{array}{l}\text { Std. Error of } \\
\text { the Estimate }\end{array}$} & \multicolumn{5}{|c|}{ Change Statistics } \\
\hline & & & & & $\begin{array}{l}\mathrm{R} \\
\text { Square } \\
\text { Change }\end{array}$ & $\begin{array}{l}\text { F } \\
\text { Change }\end{array}$ & df1 & df2 & $\begin{array}{l}\text { Sig. F } \\
\text { Chang } \\
\text { e }\end{array}$ \\
\hline 1 & $.616^{\mathrm{a}}$ & 0.379 & 0.377 & 1.428 & 0.379 & 168.67 & 1 & 276 & 0 \\
\hline 2 & $.660^{\mathrm{b}}$ & 0.436 & 0.432 & 1.363 & 0.057 & 27.739 & 1 & 275 & 0 \\
\hline 3 & $.694^{\mathrm{c}}$ & 0.482 & 0.476 & 1.309 & 0.046 & 24.2 & 1 & 274 & 0 \\
\hline 4 & $.713^{\mathrm{d}}$ & 0.509 & 0.502 & 1.277 & 0.027 & 14.881 & 1 & 273 & 0 \\
\hline
\end{tabular}

a. Predictors: (Constant), How likely are you to buy energy from your neighbour/local community energy project?

b. Predictors: (Constant), How likely are you to buy energy from your neighbour/local community energy project? How likely are you to produce energy and sell it to your neighbour?

c. Predictors: (Constant), How likely are you to buy energy from your neighbour/local community energy project? How likely are you to produce energy and sell it to your neighbour? How likely are you to buy energy from a local community energy project or your neighbour even if it were more expensive than utility provided electricity?

d. Predictors: (Constant), How likely are you to buy energy from your neighbour/local community energy project?, How likely are you to produce energy and sell it to your neighbour?, How likely are you to buy energy from a local community energy project or your neighbour even if it were more expensive than utility provided electricity?, How likely are you to invest in local generation (such as through solar panels) to reduce outages or have power during/after an extreme weather event?

e. Dependent Variable: How likely are you to contribute financially and invest money in a local community energy project? 


\subsection{Social norms and networks}

As discussed in the literature review, financial factors are only impactful in the context of adoption of community energy to a certain extent. Social norms (Table 5.7) play a crucial role as well; showing the greatest statistical significance for community owned and managed local energy generation projects. Under social norms, the following questions corresponded to descriptive and injunctive social norms (as described in the literature review) respectively:

Table 5.6 Social norms

\begin{tabular}{|c|c|}
\hline Norms & Corresponding variable \\
\hline Descriptive & $\begin{array}{r}\text { How many of your neighbours friends and acquaintances have installed a local } \\
\text { energy generation system? }\end{array}$ \\
\hline Injunctive & $\begin{array}{c}\text { I believe that most of my friends and acquaintances expect that I will adopt } \\
\text { renewable energy technologies (e.g. solar panels) within the next 5 years. }\end{array}$ \\
\hline
\end{tabular}

The regression analysis (Figure 5.10 and Table 5.7) for social norms clearly shows that the injunctive norm and expectations of friends and family is a more important consideration for local community energy participation. Previous research examining normative influence on environmental behaviour identifies that descriptive norms have an influence on injunctive norm (Rimal, 2008).

In the regression model for the social norm theme, it is interesting to note that the injunctive norm has higher relevance to the different participation models. This is possibly explained by the fact that the descriptive norm variable actually asks the question, how many of your neighbours have 
installed a renewable energy generation. Given that the numbers are low, it is not surprising to see that the descriptive norm is not more relevant to the different dependant variables associated with the participation models. This issue has been expressed in previous literature by Balcombe et al. (2013) discussing a similar issue for London which does not have visible local generation within city limits. This re-affirms the fact that the descriptive norm is unable to predict more change in the dependant variable due to the lack of visible renewable energy adoption in Toronto.

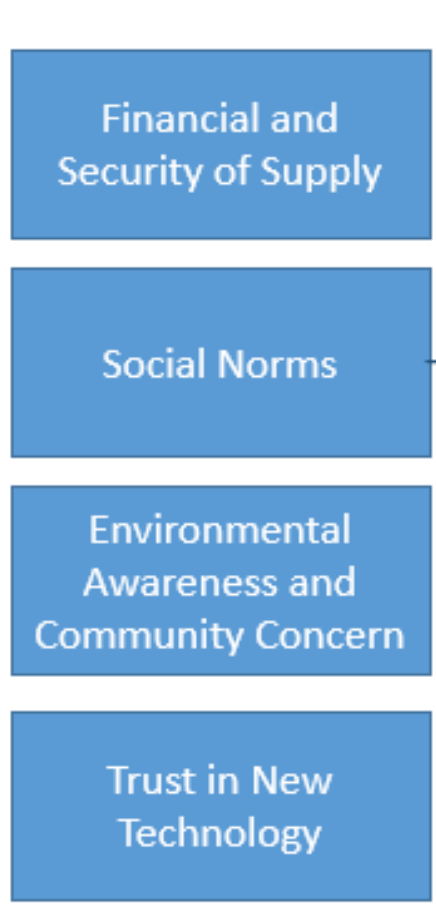

Motivational Factors

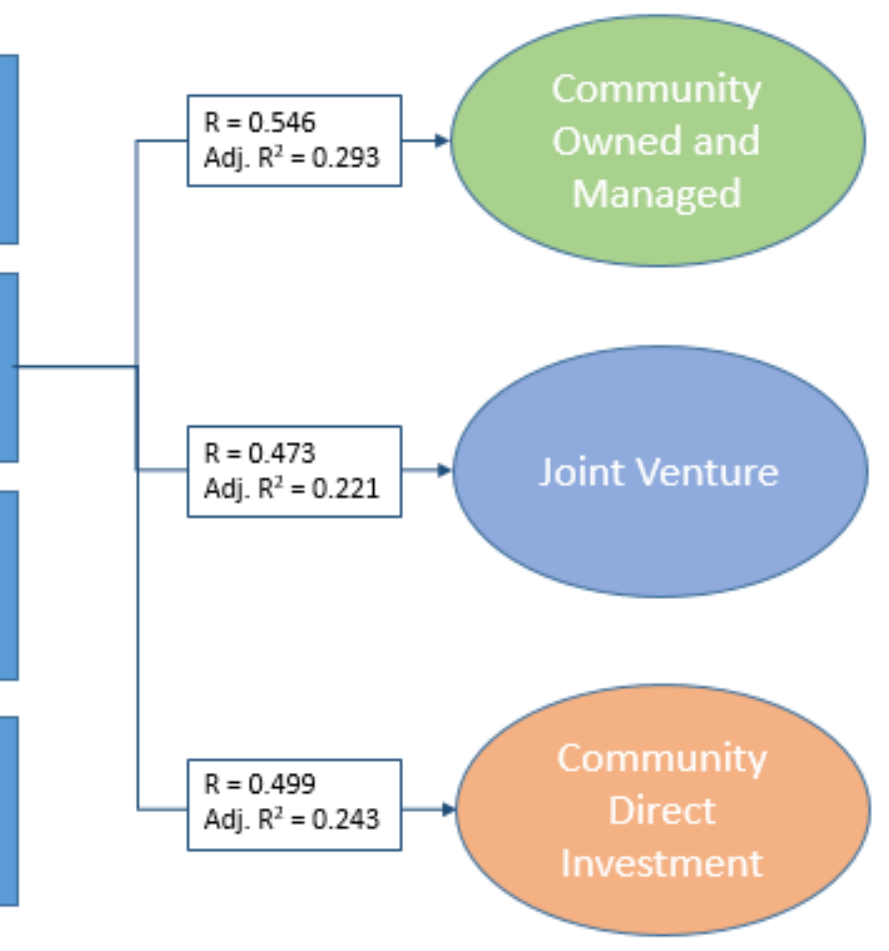

Participation Models

Figure 5.10 Social norms and community energy participation 


\section{Table 5.7 SPSS data analysis}

\section{Community owned and managed}

\begin{tabular}{|c|c|c|c|c|c|c|c|c|c|}
\hline \multicolumn{10}{|c|}{ Model Summary } \\
\hline \multirow{2}{*}{ Model } & \multirow[b]{2}{*}{$\mathrm{R}$} & \multirow[b]{2}{*}{ R Square } & \multirow[b]{2}{*}{$\begin{array}{l}\text { Adjusted R } \\
\text { Square }\end{array}$} & \multirow{2}{*}{$\begin{array}{l}\text { Std. Error } \\
\text { of the } \\
\text { Estimate }\end{array}$} & \multicolumn{5}{|c|}{ Change Statistics } \\
\hline & & & & & $\begin{array}{l}\text { R Square } \\
\text { Change }\end{array}$ & F Change & df1 & $\mathrm{df} 2$ & $\begin{array}{l}\text { Sig. F } \\
\text { Change }\end{array}$ \\
\hline 1 & $.494^{\mathrm{a}}$ & 0.244 & 0.241 & 1.622 & 0.244 & 89.758 & 1 & 278 & 0.000 \\
\hline 2 & $.546^{\mathrm{b}}$ & 0.298 & 0.293 & 1.566 & 0.054 & 21.218 & 1 & 277 & 0.000 \\
\hline
\end{tabular}

a. Predictors: (Constant), How many of your neighbours friends and acquaintances have installed a local energy generation system? (please rate on a scale of 1 - No one to 7 - all of them)

b. Predictors: (Constant), How many of your neighbours friends and acquaintances have installed a local energy generation system? (please rate on a scale of 1 - No one to 7 - all of them), I believe that most of my friends and acquaintances expect that $i$ will adopt renewable energy technologies (e.g. solar panels) within the next 5 years (please rate on a scale of 1 - strongly disagree to 7 - strongly agree)

c. Dependent Variable: How likely are you to lead and organise a local community energy project?

\section{Joint venture}

\begin{tabular}{|c|c|c|c|c|c|c|c|c|c|}
\hline \multicolumn{10}{|c|}{ Model Summary ${ }^{\mathrm{b}}$} \\
\hline & & & & Std. Error & Change $\mathrm{S}$ & tistics & & & \\
\hline Model & $\mathrm{R}$ & R Square & $\begin{array}{l}\text { Adjusted R } \\
\text { Square }\end{array}$ & $\begin{array}{l}\text { of the } \\
\text { Estimate }\end{array}$ & $\begin{array}{l}\text { R Square } \\
\text { Change }\end{array}$ & F Change & df1 & df2 & $\begin{array}{l}\text { Sig. F } \\
\text { Change }\end{array}$ \\
\hline 1 & $.473^{\mathrm{a}}$ & 0.223 & 0.221 & 1.551 & 0.223 & 79.412 & 1 & 276 & 0.000 \\
\hline
\end{tabular}

a. Predictors: (Constant), I believe that most of my friends and acquaintances expect that $\mathrm{i}$ will adopt renewable energy technologies (e.g. solar panels) within the next 5 years (please rate on a scale of 1 - strongly disagree to 7 - strongly agree)

b. Dependent Variable: How interested are you in owning a part of (such as few solar panels in a solar farm) a bigger local community energy project led by a developer? 


\section{Community direct investment}

\begin{tabular}{|c|c|c|c|c|c|c|c|c|c|}
\hline \multicolumn{10}{|c|}{ Model Summary ${ }^{\mathrm{c}}$} \\
\hline \multirow[b]{2}{*}{ Model } & \multirow[b]{2}{*}{$\mathrm{R}$} & \multirow[b]{2}{*}{ R Square } & \multirow[b]{2}{*}{$\begin{array}{l}\text { Adjusted R } \\
\text { Square }\end{array}$} & \multirow{2}{*}{$\begin{array}{l}\text { Std. Error } \\
\text { of the } \\
\text { Estimate }\end{array}$} & \multicolumn{5}{|c|}{ Change Statistics } \\
\hline & & & & & $\begin{array}{l}\text { R Square } \\
\text { Change }\end{array}$ & F Change & df1 & $\mathrm{df} 2$ & $\begin{array}{l}\text { Sig. F } \\
\text { Change }\end{array}$ \\
\hline 1 & $.457^{\mathrm{a}}$ & 0.209 & 0.206 & 1.612 & 0.209 & 73.295 & 1 & 278 & 0.000 \\
\hline 2 & $.499^{b}$ & 0.249 & 0.243 & 1.574 & 0.040 & 14.693 & 1 & 277 & 0.000 \\
\hline
\end{tabular}

a. Predictors: (Constant), I believe that most of my friends and acquaintances expect that i will adopt renewable energy technologies (e.g. solar panels) within the next 5 years (please rate on a scale of 1 - strongly disagree to 7 - strongly agree)

b. Predictors: (Constant), I believe that most of my friends and acquaintances expect that i will adopt renewable energy technologies (e.g. solar panels) within the next 5 years (please rate on a scale of 1 - strongly disagree to 7 - strongly agree), How many of your neighbours friends and acquaintances have installed a local energy generation system? (please rate on a scale of 1 - No one to 7 - all of them)

c. Dependent Variable: How likely are you to contribute financially and invest money in a local community energy project? 


\subsection{Environmental awareness and community concern}

Along with asking participants about their concern for the environment, they were also asked to self-asses their understanding of community energy. Results (Figure 5.11 and Table 5.8) show that knowledge of local community energy projects is the most prominent variable impacting participation in community energy projects.

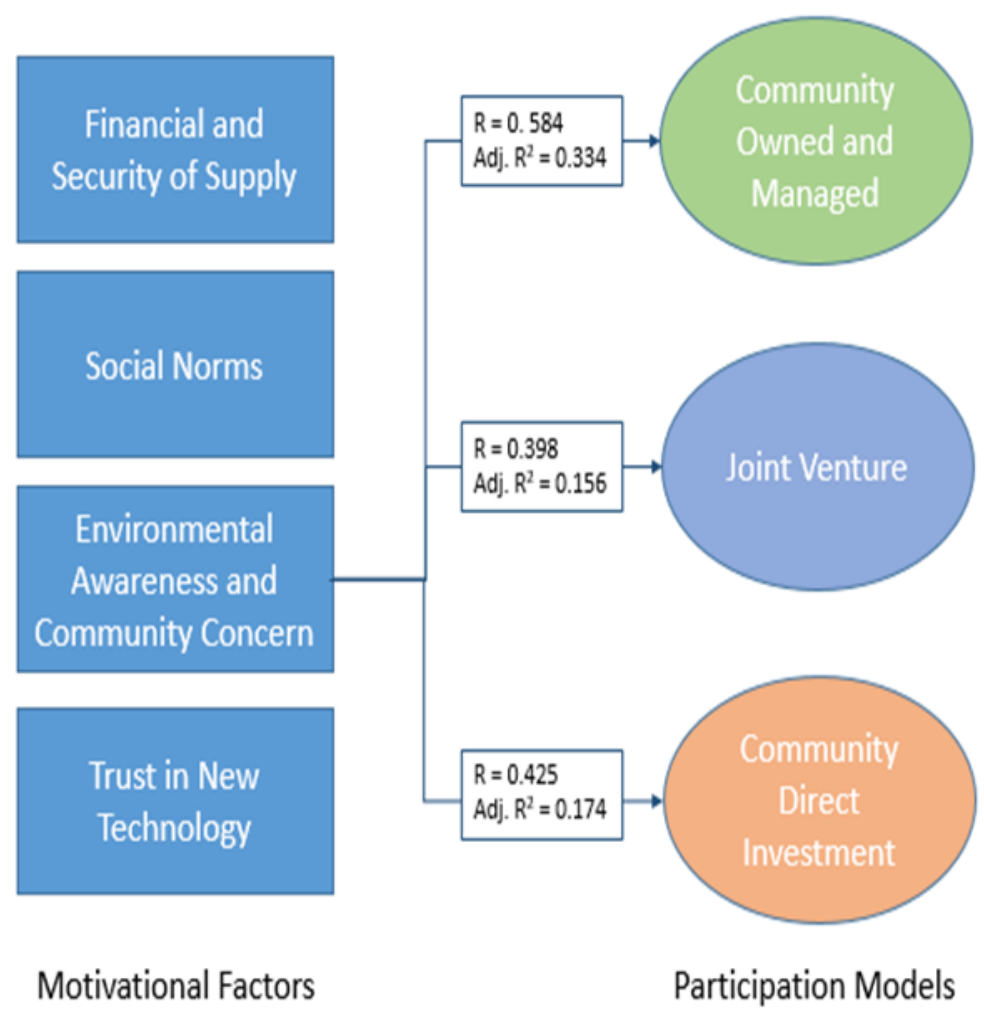

Figure 5.11 Environmental factors and participation models 
Participants who were identified as understanding the concept of community energy were more likely to participate in community energy project. The data analysis shows that awareness and understanding variable factored heavily into the decision to participate in community energy more than any other factor. Interestingly, caring for the environment is not factored into the models of relevance for community joint venture and community direct investment. Community connection factors into relevance for community led and managed energy project participation.

It is interesting to note that in our factor analysis, the question of community connectedness has actually factored in with environmental concern and awareness of the concept of community energy. When asked specifically how likely they were to invest in local community energy projects, vs whether they would like to lead and manage a community energy project, regression analysis shows that knowledge of community energy is a bigger predictor for investment, vs. feeling a connection with their community led to higher intentions of leading and managing a community energy project. This finding is supported by Kalkbrenner and Roosen (2016) who consider environmental concern-driven behaviour to be a subset of social and environmental norms. While conducting the factor analysis, a high correlation factor of .5 was chosen and numbers under were not shown in the graph. If the threshold is reduced to include .3 value significance, then the environmental and social variables show to be factoring into both. 


\section{Table 5.8 SPSS data analysis}

\section{Community led and managed}

Model Summary ${ }^{\mathrm{d}}$

\begin{tabular}{|c|c|c|c|c|c|c|c|c|c|}
\hline \multirow[b]{2}{*}{ Model } & \multirow[b]{2}{*}{$\mathrm{R}$} & \multirow[b]{2}{*}{$\begin{array}{l}\mathrm{R} \\
\text { Square }\end{array}$} & \multirow[b]{2}{*}{$\begin{array}{l}\text { Adjusted } \\
\mathrm{R} \\
\text { Square }\end{array}$} & \multirow[b]{2}{*}{$\begin{array}{l}\text { Std. Error of } \\
\text { the Estimate }\end{array}$} & \multicolumn{5}{|c|}{ Change Statistics } \\
\hline & & & & & $\begin{array}{l}\mathrm{R} \\
\text { Square } \\
\text { Change }\end{array}$ & $\begin{array}{l}\mathrm{F} \\
\text { Change }\end{array}$ & df1 & df2 & $\begin{array}{l}\text { Sig. F } \\
\text { Change }\end{array}$ \\
\hline 1 & $.511^{\mathrm{a}}$ & 0.261 & 0.259 & 1.604 & 0.261 & 98.081 & 1 & 277 & 0.000 \\
\hline 2 & $.566^{\mathrm{b}}$ & 0.321 & 0.316 & 1.541 & 0.059 & 24.141 & 1 & 276 & 0.000 \\
\hline 3 & $.584^{\mathrm{c}}$ & 0.342 & 0.334 & 1.520 & 0.021 & 8.608 & 1 & 275 & 0.004 \\
\hline
\end{tabular}

a. Predictors: (Constant), I have a good understanding of the concept of local community energy (please rate on a scale of 1 - strongly disagree to 7 - strongly agree)

b. Predictors: (Constant), I have a good understanding of the concept of local community energy (please rate on a scale of 1 - strongly disagree to 7 - strongly agree), I feel strongly attached to the community I live in and I participate in community activities. (please rate on a scale of 1 - strongly disagree to 7 - strongly agree)

c. Predictors: (Constant), I have a good understanding of the concept of local community energy (please rate on a scale of 1 - strongly disagree to 7 - strongly agree), I feel strongly attached to the community I live in and I participate in community activities. (please rate on a scale of 1 - strongly disagree to 7 - strongly agree), I care about the environment. (please rate on a scale of 1 - strongly disagree to 7 - strongly agree)

d. Dependent Variable: How likely are you to lead and organise a local community energy project?

\section{Joint venture}

Model Summary ${ }^{\mathrm{b}}$

\begin{tabular}{|c|c|c|c|c|c|c|c|c|c|}
\hline \multirow[b]{2}{*}{ Model } & \multirow[b]{2}{*}{$\mathrm{R}$} & \multirow[b]{2}{*}{$\begin{array}{l}\mathrm{R} \\
\text { Square }\end{array}$} & \multirow[b]{2}{*}{$\begin{array}{l}\text { Adjusted } \\
\mathrm{R} \\
\text { Square }\end{array}$} & \multirow[b]{2}{*}{$\begin{array}{l}\text { Std. Error of } \\
\text { the Estimate }\end{array}$} & \multicolumn{5}{|c|}{ Change Statistics } \\
\hline & & & & & $\begin{array}{l}\mathrm{R} \\
\text { Square } \\
\text { Change }\end{array}$ & $\begin{array}{l}\mathrm{F} \\
\text { Change }\end{array}$ & df1 & df 2 & $\begin{array}{l}\text { Sig. F } \\
\text { Change }\end{array}$ \\
\hline 1 & $.398^{\mathrm{a}}$ & 0.159 & 0.156 & 1.614 & 0.159 & 52.080 & 1 & 276 & 0.000 \\
\hline
\end{tabular}

a. Predictors: (Constant), I have a good understanding of the concept of local community energy (please rate on a scale of 1 - strongly disagree to 7 - strongly agree) 
b. Dependent Variable: How interested are you in owning a part of (such as few solar panels in a solar farm) a bigger local community energy project led by a developer?

\section{Community direct \\ investment}

\begin{tabular}{|c|c|c|c|c|c|c|c|c|c|}
\hline \multicolumn{10}{|c|}{ Model Summary } \\
\hline \multirow[b]{2}{*}{ Model } & \multirow[b]{2}{*}{$\mathrm{R}$} & \multirow[b]{2}{*}{$\begin{array}{l}\mathrm{R} \\
\text { Square }\end{array}$} & \multirow[b]{2}{*}{$\begin{array}{l}\text { Adjusted } \\
\mathrm{R} \\
\text { Square }\end{array}$} & \multirow[b]{2}{*}{$\begin{array}{l}\text { Std. Error of } \\
\text { the Estimate }\end{array}$} & \multicolumn{5}{|c|}{ Change Statistics } \\
\hline & & & & & $\begin{array}{l}\mathrm{R} \\
\text { Square } \\
\text { Change }\end{array}$ & $\begin{array}{l}\mathrm{F} \\
\text { Change }\end{array}$ & df1 & df2 & $\begin{array}{l}\text { Sig. F } \\
\text { Change }\end{array}$ \\
\hline 1 & $.401^{\mathrm{a}}$ & 0.161 & 0.158 & 1.660 & 0.161 & 53.116 & 1 & 277 & 0.000 \\
\hline 2 & $.425^{\mathrm{b}}$ & 0.180 & 0.174 & 1.644 & 0.019 & 6.566 & 1 & 276 & 0.011 \\
\hline
\end{tabular}

a. Predictors: (Constant), I have a good understanding of the concept of local community energy (please rate on a scale of 1 - strongly disagree to 7 - strongly agree)

b. Predictors: (Constant), I have a good understanding of the concept of local community energy (please rate on a scale of 1 - strongly disagree to 7 - strongly agree), I feel strongly attached to the community I live in and I participate in community activities. (please rate on a scale of 1 - strongly disagree to 7 - strongly agree)

c. Dependent Variable: How likely are you to contribute financially and invest money in a local community energy project? 


\subsection{Uncertainty and trust in new technology}

Regression analysis (Figure 5.12 and Table 5.9) for the variable for trust in technology for the three different dependant variables was conducted. It showed that trust in new technology plays the most significant role for community direct investment. Trust in technology is not a huge motivating factor for the other two participation models, having an especially low $\mathrm{R}^{2}$ for leading and managing a community energy project.

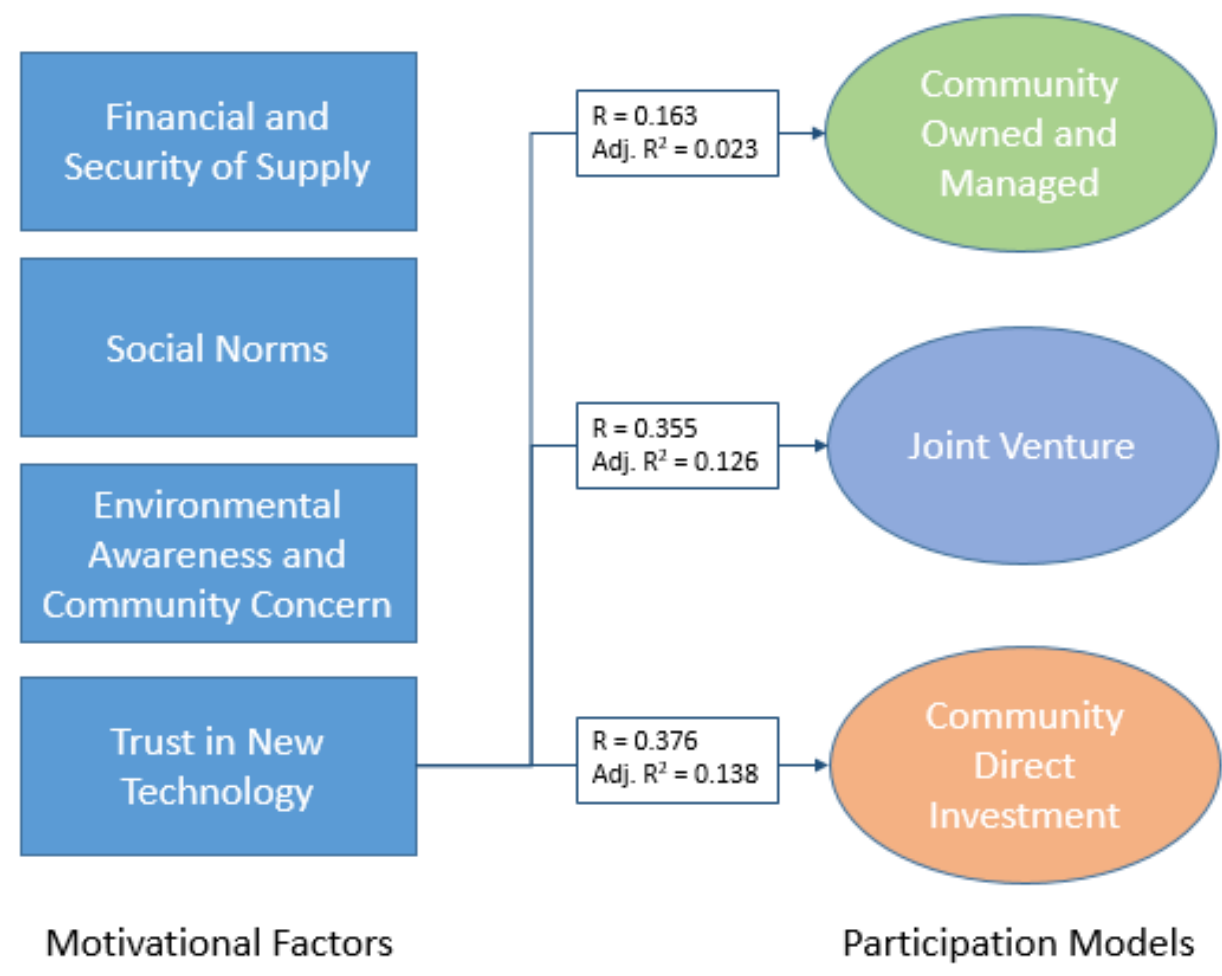

Figure 5.12 Trust in technology and participation models 
Table 5.9 SPSS data analysis

\begin{tabular}{|c|c|c|c|c|c|c|c|c|c|}
\hline \multirow[b]{2}{*}{ Model } & \multirow[b]{2}{*}{$\mathrm{R}$} & \multirow[b]{2}{*}{ R Square } & \multirow{2}{*}{$\begin{array}{l}\text { Adjusted } \\
\text { R } \\
\text { Square }\end{array}$} & \multirow{2}{*}{$\begin{array}{l}\text { Std. } \\
\text { Error of } \\
\text { the } \\
\text { Estimate }\end{array}$} & \multicolumn{5}{|c|}{ Change Statistics } \\
\hline & & & & & $\begin{array}{l}\text { R } \\
\text { Square } \\
\text { Change }\end{array}$ & $\begin{array}{l}\text { F } \\
\text { Change }\end{array}$ & df1 & $\mathrm{df} 2$ & $\begin{array}{l}\text { Sig. F } \\
\text { Change }\end{array}$ \\
\hline 1 & $.163^{\mathrm{a}}$ & 0.027 & 0.023 & 1.841 & 0.027 & 7.553 & 1 & 277 & 0.006 \\
\hline
\end{tabular}

a. Predictors: (Constant), How likely are you to trust and adopt new energy generation technologies?

b. Dependent Variable: How likely are you to lead and organise a local community energy project?

\section{Joint venture}

Model Summary

\begin{tabular}{|c|c|c|c|c|c|c|c|c|c|}
\hline \multirow[b]{2}{*}{ Model } & \multirow[b]{2}{*}{$\mathrm{R}$} & \multirow{2}{*}{$\begin{array}{l}\text { R } \\
\text { Square }\end{array}$} & \multirow{2}{*}{$\begin{array}{l}\text { Adjusted } \\
\text { R } \\
\text { Square }\end{array}$} & \multirow{2}{*}{$\begin{array}{l}\text { Std. } \\
\text { Error of } \\
\text { the } \\
\text { Estimate }\end{array}$} & \multicolumn{5}{|c|}{ Change Statistics } \\
\hline & & & & & $\begin{array}{l}\mathrm{R} \\
\text { Square } \\
\text { Change }\end{array}$ & $\begin{array}{l}\text { F } \\
\text { Change }\end{array}$ & df1 & df2 & $\begin{array}{l}\text { Sig. F } \\
\text { Change }\end{array}$ \\
\hline 1 & $.355^{\mathrm{a}}$ & 0.126 & 0.123 & 1.645 & 0.126 & 39.849 & 1 & 276 & 0 \\
\hline
\end{tabular}

a. Predictors: (Constant), How likely are you to trust and adopt new energy generation technologies? 
b. Dependent Variable: How interested are you in owning a part of (such as few solar panels in a solar farm) a bigger local community energy project led by a developer?

\section{Community direct investment}

Model Summary ${ }^{\mathrm{b}}$

\begin{tabular}{|c|c|c|c|c|c|c|c|c|c|}
\hline \multirow[b]{2}{*}{ Model } & \multirow[b]{2}{*}{$\mathrm{R}$} & \multirow[b]{2}{*}{$\begin{array}{l}\mathrm{R} \\
\text { Square }\end{array}$} & \multirow[b]{2}{*}{$\begin{array}{l}\text { Adjusted } \\
\text { R } \\
\text { Square }\end{array}$} & \multirow{2}{*}{$\begin{array}{l}\text { Std. } \\
\text { Error of } \\
\text { the } \\
\text { Estimate }\end{array}$} & \multicolumn{5}{|c|}{ Change Statistics } \\
\hline & & & & & $\begin{array}{l}\mathrm{R} \\
\text { Square } \\
\text { Change }\end{array}$ & $\begin{array}{l}\mathrm{F} \\
\text { Change }\end{array}$ & df1 & $\mathrm{df} 2$ & $\begin{array}{l}\text { Sig. F } \\
\text { Change }\end{array}$ \\
\hline 1 & $.376^{\mathrm{a}}$ & 0.141 & 0.138 & 1.68 & 0.141 & 45.491 & 1 & 277 & 0 \\
\hline
\end{tabular}

a. Predictors: (Constant), How likely are you to trust and adopt new energy generation technologies?

b. Dependent Variable: How likely are you to contribute financially and invest money in a local community energy project? 


\subsection{Summary by Participation Model}

\section{Community owned and managed}

This model of community energy development involves the highest level of participation from participants. Financial factors are the most important, followed closely by environmental and social norms and finally trust in new technology. Figure 5.13 below summarizes from the previous regression models the motivations to this model of community energy.

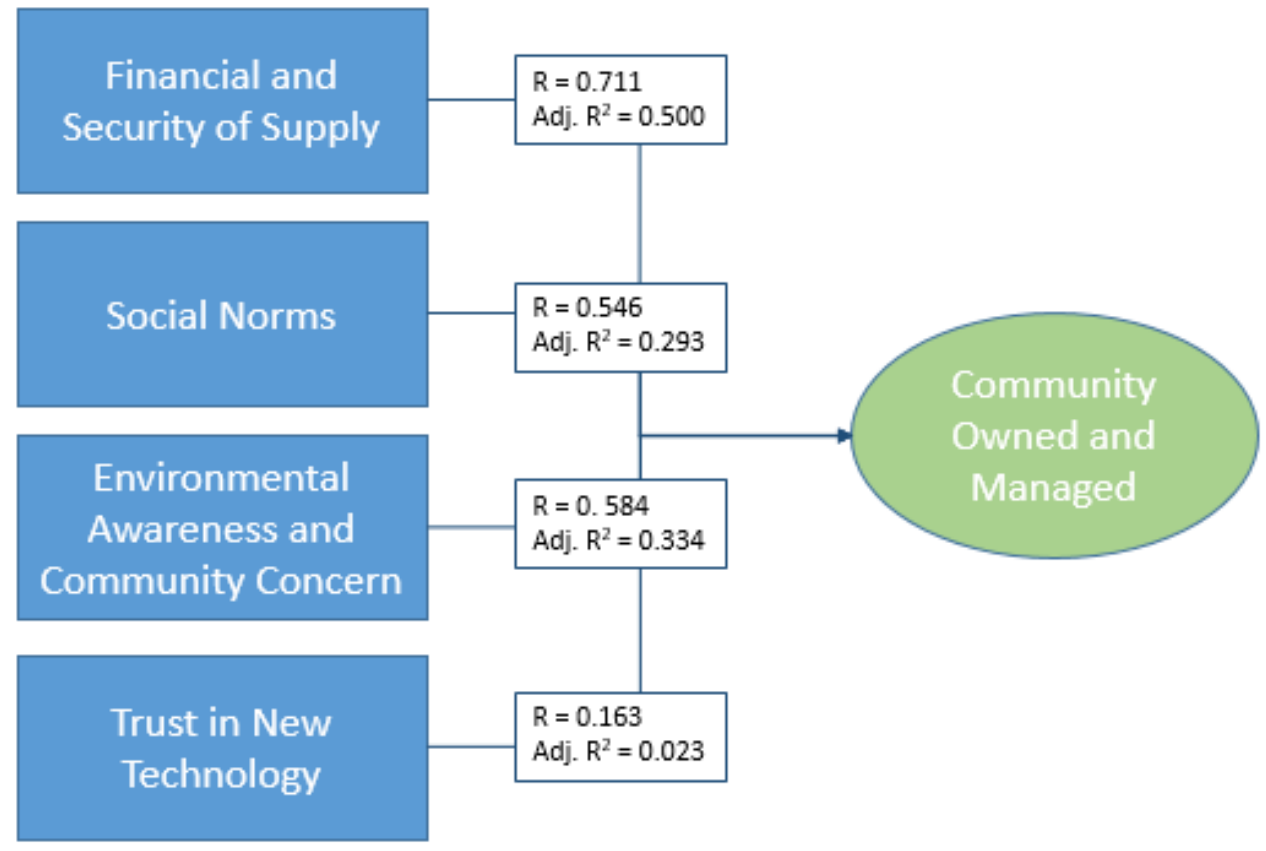

Motivational Factors

Participation Models

Figure 5.13 Motivations for community led and managed projects 


\section{Joint venture}

This model of participation involves a joint effort between community members and a third party developing a local community generation project. While financial, environmental and social factors are important; this model (Figure 5.14) shows the most significant support for trust in new technology. Furthermore, under financial factors, impact on property value is also an important factor for joint venture community projects. This shows that people are more vary when a private organisation is involved and need more financial and technological reassurances for participation.

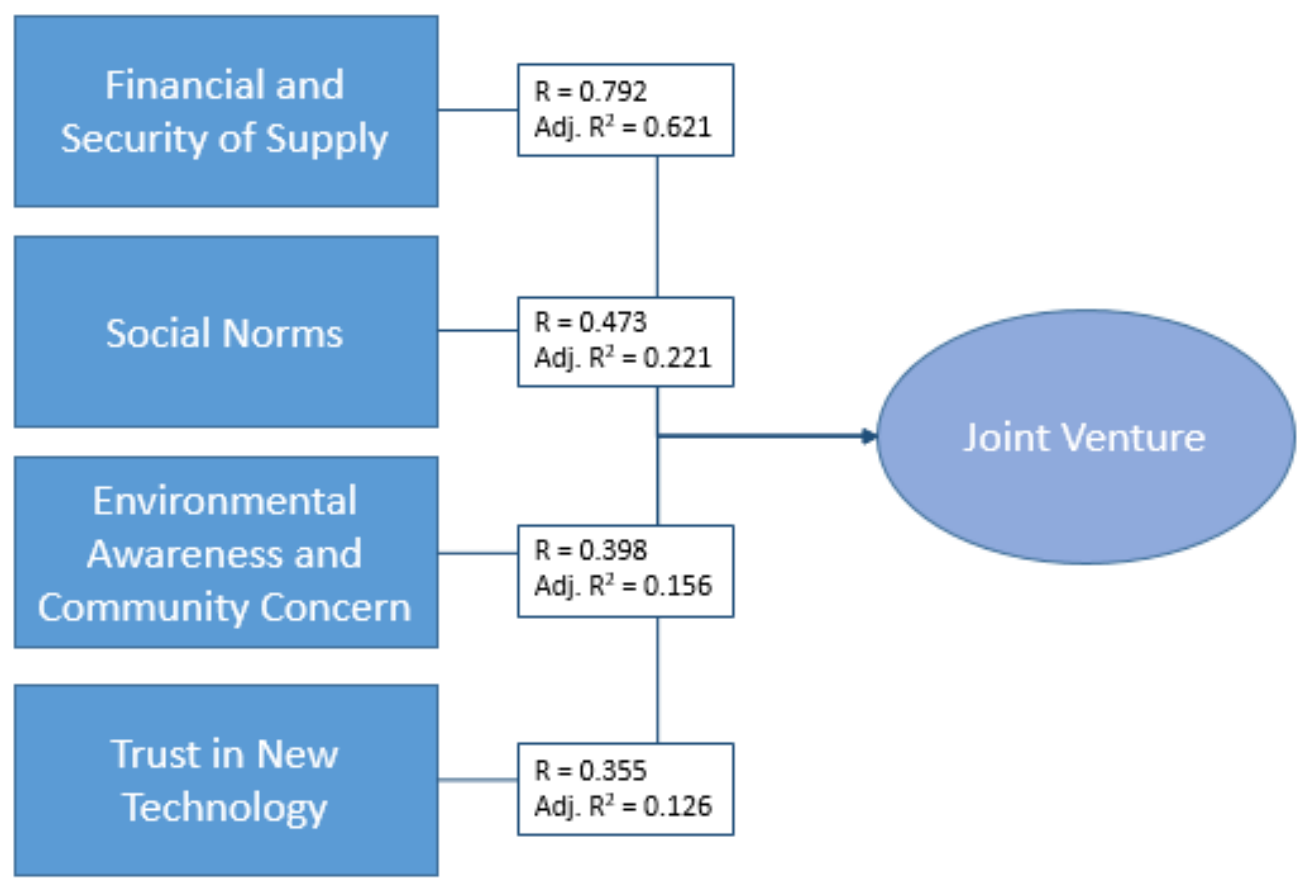

Motivational Factors

Participation Models

Figure 5.14 Motivations for participation in projects created in partnership with a third party organization 


\section{Community direct investment}

Similarly, in community direct investment financial factors are most important. Trust in technology is also important for community direct investment decision-making. This is an important consideration for private companies who are interested in creating opportunities for local community energy especially in participation with community members. Identified benefits of participation in a financial context, along with expressing trust in technology is important to solicit participation from community members.

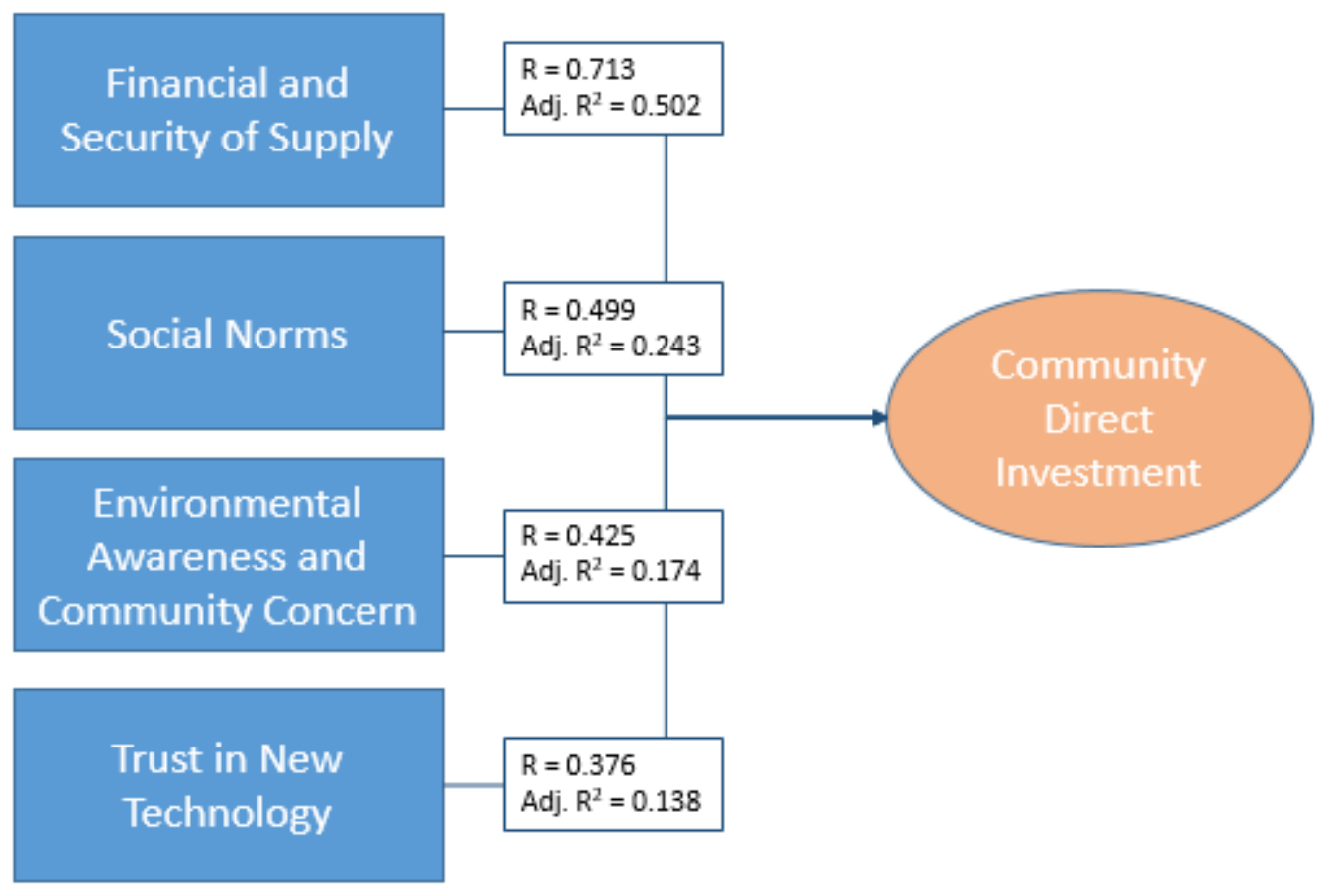

Motivational Factors

Participation Models

Figure 5.15 Motivations for participation in community direct investment of community energy projects 


\section{Updated conceptual model}

The initial model of analysis was based on literature review. Following the data analysis and the isolation of four factors instead of initially used five, the conceptual framework was updated accordingly. Figure 5.16 provides the updated model.

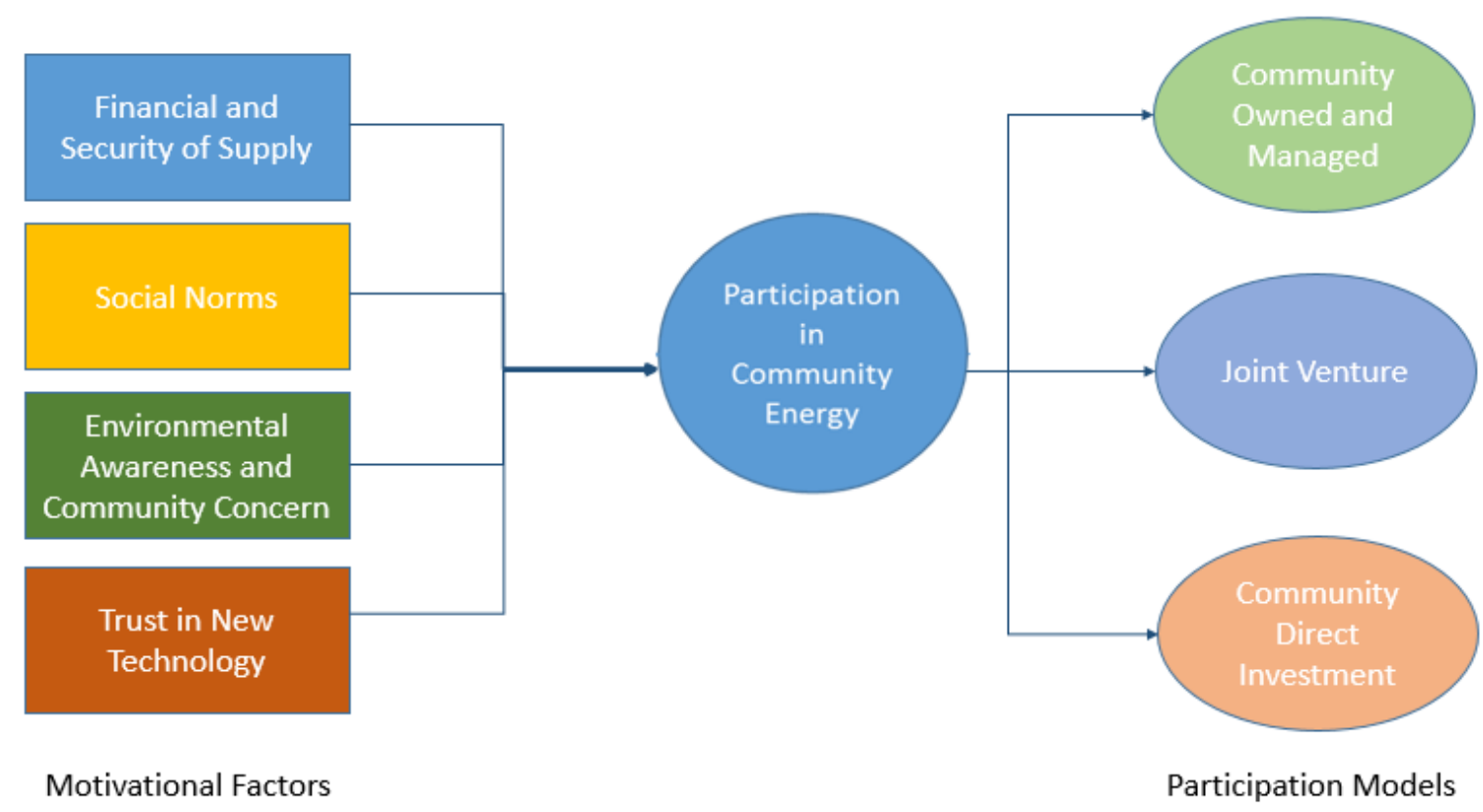

Figure 5.16 - Updated Conceptual Model

The updated model identified four key factors that influence the various levels of participation in community energy, in Toronto. This clearly identified financial factors as being the most crucial factor impacting decision-making regarding community energy projects. Other factors of social norms, environmental and community concerns and trust in technology also influence decisionmaking as it related to participation in community energy projects but to a lesser extent. Implications are discussed later in Section 6 - Conclusions and Implications. 


\subsection{Quality of research}

The quality of research has been typically defined by two measures, that of validity and reliability (Kirk \& Miller, 1986).

Validity: This is a measure of how pertinent the questions are to determine the wanted outcomes related to the objective of the research.

Reliability: This is the measure of whether the same results can be obtained by following the same steps during research, as done previously.

For the present study, a mixed-methods approach was utilised, and validity and reliability were considered throughout the research design, data collection and data analysis phases of quantitative and qualitative streams. Table 5.10 explains the various methods utilised to ascertain that the research is valid and reliable.

Table 5.10 Research quality determination procedures

\begin{tabular}{|l|l|l|}
\hline Test & Method utilised & Stage of research \\
\hline Construct validity & $\begin{array}{l}\text { The sample group was random and multiple sources } \\
\text { for data collection were utilised. }\end{array}$ & Data collection \\
\hline Internal validity & $\begin{array}{l}\text { The researcher discussed their research and research } \\
\text { design with various experts to ascertain internal } \\
\text { validity. The questionnaire was shown to many } \\
\text { experts and their suggestions included where } \\
\text { possible to improve the validity of the questionnaire } \\
\text { and the research as a whole. }\end{array}$ & $\begin{array}{l}\text { Research design } \\
\text { Data collection }\end{array}$ \\
\hline External validity & $\begin{array}{l}\text { The researcher compared and presented evidence } \\
\text { from existing literature to determine } \\
\text { generalisability. }\end{array}$ & $\begin{array}{l}\text { Research design } \\
\text { Data analysis }\end{array}$ \\
\hline Reliability & $\begin{array}{l}\text { A sample size of 267 participants provides 95\% } \\
\text { confidence level with a confidence interval of 5.9\% } \\
\text { data collected from residents of the city of Toronto. } \\
\text { Furthermore, data was determined to be normal and } \\
\text { co-variance numbers were fine. Only statistically } \\
\text { significant values were discussed in the results. }\end{array}$ & $\begin{array}{l}\text { Data collection } \\
\text { Data analysis }\end{array}$ \\
\hline
\end{tabular}




\subsection{Limitations}

The semi-structured interview sample size is small. This sample can be expanded upon to include more interviews. The research findings could have been shared back with the semi-structured interviewees to solicit their feedback on the findings. This step would have further strengthened the validity of the research. However, due to time constraints, this step was not undertaken. Furthermore, the questionnaire sample size could also be expanded to get a higher level of the confidence interval for the data. The questionnaire in the present study solicited opinions on the topic of urban community energy only in the context of Toronto. The findings from this study are specific to Toronto and can be generalised for Ontario, given the same jurisdictional construct present for other urban centres concerning the energy landscape. However, challenges arise as each place has its unique characteristics. A broader survey could be conducted including a bigger base of urban Ontario centres beyond Toronto to understand better, how community energy can flourish in urban centres of Ontario.

Second, while it is believed by the researcher that studying the intentions of potential adopters (stated preferences) is an extremely valuable addition to the analysis of past decisions by actual adopters (revealed preferences), the researcher would like to point out those choices were made under a hypothetical scenario where no actual commitment to participation in community energy projects was required. All stated preference approaches can be subject to social desirability biases (Van de Mortel, 2008). 


\section{Conclusions and implications}

The current research sought to address the principle research questions "How can community energy manifest in urban centres?", "What level of participation are people interested in when it comes to community energy projects?", and "What motivates the different levels of participation in urban community energy projects?". The results indicate that community energy in an urban centre of Toronto may be realised with residents partnering with the local utility or third party companies that lead the planning and development of projects. This conclusion is derived from the quantitative data as well as the expert opinions expressed during the semi-structured interviews. While most people appear less willing to participate directly, it was clear that financial factors will be most crucial when soliciting participation from community residents in such projects, whether through investment of time or money. The preference to have these projects developed and managed by others means that social norms, environmental awareness and community concern play a more limited role in stimulating participation.

The rise of the collaborative economy examples have been highly illustrative of the fact that the status quo is being challenged in most sectors. This challenge arises from the failure of current economic models, which are not leading to the well-being of the many. There has been an increase in the demand for inclusion of citizens in decision-making, which has been traditionally controlled by the few. Technological advancements have been particularly important in amplifying this demand and providing certain avenues for creating solutions. This is true of the electricity sector, which though traditionally centralised, is moving towards a decentralised model. Through technological innovation, local micro-generation of energy is increasingly possible in urban centres around the world. However, capital costs are still steep and community financing can support development of such projects. 
Urban centres, which are large consumers of energy, also have the potential for local generation to meet demand. The current research explores Toronto residents' interests in participation in local community generation of energy. Most people surveyed indicated low to medium levels of preferred participation. While this research has explored and presented successful instances of community energy around the world, at various levels of participation, this research also acknowledges that community energy is difficult to realise. A high amount of co-ordination is required to create community energy projects that truly involve the community in the decisionmaking process, as having large number of participants with differing priorities can make the process of consensus building challenging. Considering the realistic possibilities for Toronto, this research suggests that joint ventures and community direct investment into $3^{\text {rd }}$ party developed and maintained projects are the most readily acceptable models of participation.

As financial costs are very important to residents of Toronto, with the cancellation of the microfit and FiT schemes, community energy development is expected to suffer a setback. Thus, it becomes increasingly important to identify the motivators for community energy participation beyond that of the financial gain goal frame of motivation. Social norms can play a significant role in adoption of local community energy and suggests that sweeping policy changes might not be the best solution for increased citizen participation and adoption of local community generation of energy going forward. Messaging focused on descriptive and injunctive social norms can be utilised to further the adoption of local community energy generation. An example would be to highlight statistics about neighbours who have joined local community energy projects, to motivate participation.

This research has implications for policy that supports development of businesses in the energy sector. Most people are not interested in being actively involved in the managing of a community 
energy project. However, they are interested in local generation and this creates the space for a company to come and provide the development and management of a local community energy project. There is a certain opportunity here for innovators to create new social innovations around local energy generation, which provide participants with a return on their investment. The motivational factors research provides support for well-known insights such as financial motivation being crucial for adoption of community energy and local generation, but also presents insights into the importance of other motivators such as social norms, environmental awareness and community concern as well as trust in new technology. This is especially interesting when the motivators are studied for different models of community energy discussed.

The current research explores these questions for the urban centre of Toronto. These results are expected to be generally replicable in other urban jurisdictions, as far as the motivations are concerned. It is expected that financial concerns will remain paramount to other factors such as social norms, environmental concerns and trust in technology, irrespective of the jurisdiction. However, in a non-urban setting, where there is more space and more visible signs of local generation (e.g. solar panels, wind turbines), social norms might play a bigger role than suggested in the current research. Similarly, communities with a high environmental consciousness, might see higher levels of participation (irrespective of urban, sub-urban or rural). In addition, sub-urban or rural communities facing higher incidences of loss of power due to extreme weather might also find that to be a bigger motivator to adoption of local community generation than a centre like Toronto, which faces relatively low levels of power disruption.

\section{Policy implications}

Government policies providing financial incentives (Feed-in-tariff, tax subsidies) have led to the initiation of community energy in many jurisdictions around the world. Financial motivators are 
considered key to adoption of local community energy generation. This research provides insights into additional motivators that can play a role in promoting community energy in Toronto and other urban centres of Ontario. Understanding various motivators beyond financial considerations can help create policy that drive adoption of citizen financing in community energy generation. Both provincial and municipal governments in Toronto can incentivise residents to adopt local community generation as well as business and local utilities to create non-traditional business models that solicit citizen financing and participation. Furthermore, government policy can mandate community benefits as requirements for all community energy projects developed along with asking for minimum levels of local participation. In Ontario, municipalities as major shareholders of local utilities can adopt policy that encourages further community participation in energy production. The provincial government could adopt a community energy and community benefits strategy that would further incentivize community participation in local energy projects. Creating a dedicated awareness campaign as part of the strategy could lead to social norms development around community energy in Ontario. Municipalities should create more concrete pathways in community energy planning that encourages the involvement of more residents in the decisions around how energy is produced, managed and consumed in the community. This research provides important policy implications for the energy sector, in particular for Ontario's local electricity distribution companies operating in urban settings. Identifying different levels of participation and finding the correct motivators behind each can help to stimulate community participation. Local distribution companies, in this case Toronto Hydro, should capitalize on the interest of residents to participate in community energy by providing vehicles such as the SMUD SolarShares program discussed in the literature review (see section 2.3). Utility companies in Ontario should also strive to promote innovative programs and projects which 
involve more citizen-participation. Furthermore, they should also incentivize development of social enterprises and start-ups in the energy space.

Environmental education and awareness is another important factor in motivating Toronto residents to participate in community energy generation. The municipal government could tackle this issue by creating a city-wide program of public engagement, involving local community members as facilitators/animators. These local resources would engage their communities on various issues, starting with community energy and provide communities with development support. Hiring community energy animators would also help with the problems of complexity of issues and language barriers. This would be similar to the environmental animators hired under the City of Toronto's Green Living program that ran from 2008-2012 (Barnes, 2012).

Businesses have the opportunity to create non-traditional business models with increased citizen financing. Businesses interested in creating such projects should focus on all the motivating factors. Being realistic about the effort required to motivate people to participate in community energy is important. Community energy projects need significant work to set up, from not only a technical perspective but also social factors such as coordinating a multitude of actors with different focuses. Not everyone is willing or has the capacity to participate deeply. However, many people are interested in local clean generation of energy and that interest needs to be tapped into. This can be done by providing avenues for various levels of participation through innovative business models.

Financial factors are key and should be emphasised upon, however, emphasis on important factors of social norms, environmental and community concerns along with trust of technology need to be part of participation recruitment strategies. There is some role for institutional actors as well, such as universities, or high schools to create opportunities for local community generation on their 
premises, which are financed through citizen funding. Furthermore, institutional and government actors can promote social norms by adopting visible local energy generation systems, spurring further adoption. A collaborative effort between government, institutional actors as well as businesses is required to promote local community generation in Toronto and other urban centres in Ontario.

\section{Contribution \& Future work}

The current research adds to existing literature exploring participation in community energy projects, by looking at scope of community energy in urban centres in Ontario. The novelty this research presents is identifying the different motivations and finding their influence for different levels of participation of citizens in local community energy projects. This research proposes a framework for motivation of participation in different modes of community energy projects. The goal of the research was to create insights for future development of community energy projects that focus on increased individual participation from community members in various modes. The financial factor was found to be most important. However, a deeper understanding of what it means for consumers as it relates to their taxes, impact on their bills (for customers who receive them), versus consumers who do not receive bills, are interesting financial questions not explored in the current study.

There is room for further research a bigger evaluation of different urban centres in Ontario and other provinces in Canada will provide a deeper understanding of the Canadian urban potential for community energy. There might be differences based on provincial energy legislations as well, to how community energy manifests in different urban centres around Canada.

The current study focused on Toronto, and assumed a common level of reliability for the whole city of Toronto. However, there are certain low reliability hotspots around the city. The 
questionnaire did not ask the respondents to identify the area of Toronto they resided in; hence, a deeper analysis of how respondents from those hotspot areas might have answered the questions was not contrasted with the answers of respondents from other areas of Toronto. This could be an area of further exploration as well.

There are complexities related to urban infrastructure and low consumer interests in community energy, and given the multiplicity of jurisdictional governance associated with electricity generation, transmission, and distribution means that no one community energy model can necessarily be generalized. Further research is required to create an understanding of different urban places and unique models suited to the specific jurisdiction. The research does not address rural community energy projects in Ontario: many other studies focus on it, but the researchers' interest is urban energy and development of community-led energy projects in urban centres. A study that compares the two different setting for community energy can provide interesting contrast, if any, between rural and urban differences in motivation Another big question is around the understanding of risk appetite of participants and how that impacts their motivations for joining community energy projects. Who takes on the risk in these systems is a big question, one that has been dealt with by some researchers before (Müller \& Rommel, 2010; Holburn et al., 2010) and needs further exploration. 
Appendix A: Test of Normality Results

Age group $(18-35=1,36-64=2,65$ and above $=3$ )
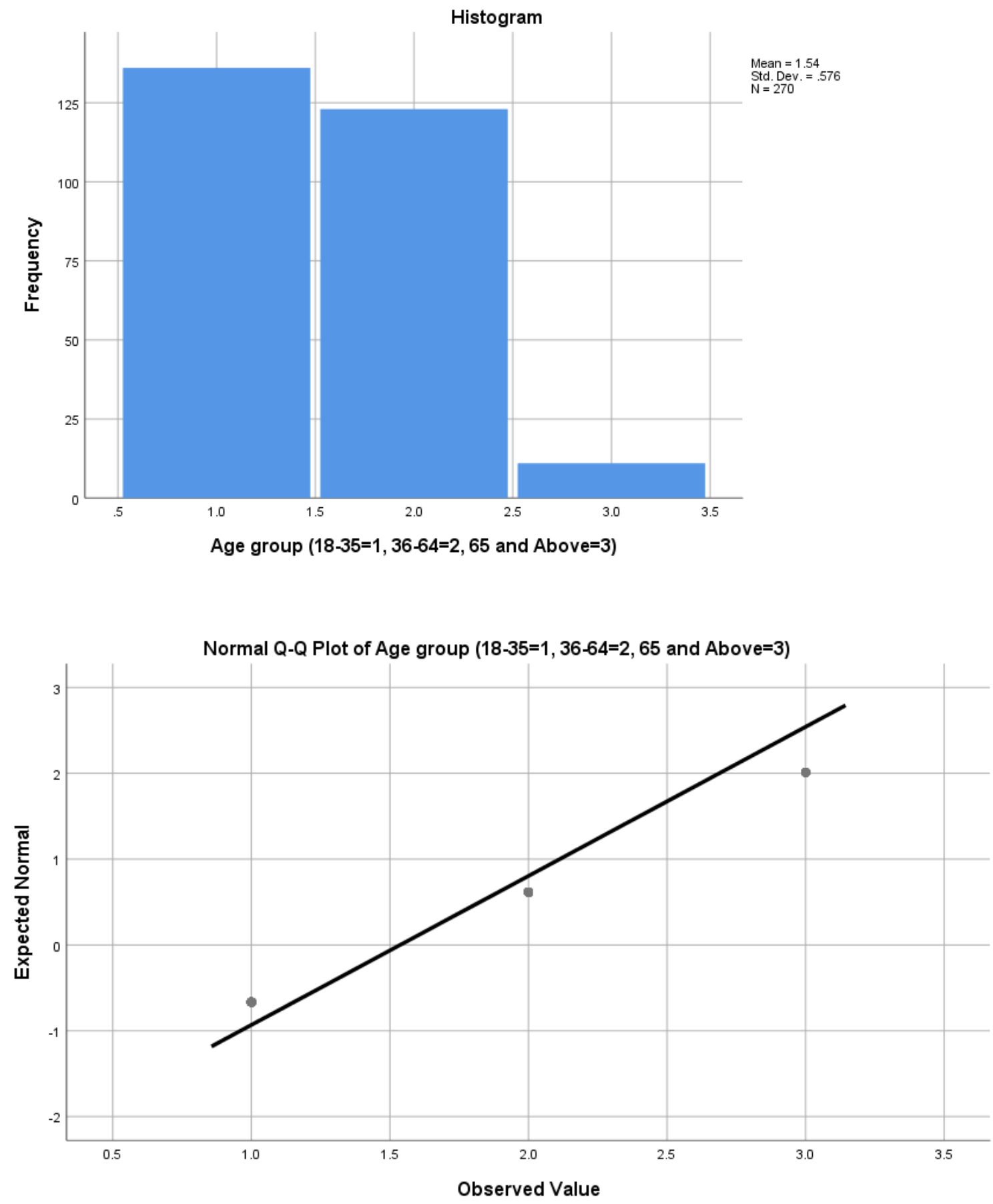


\section{Own (=1) or Rent (=2)}
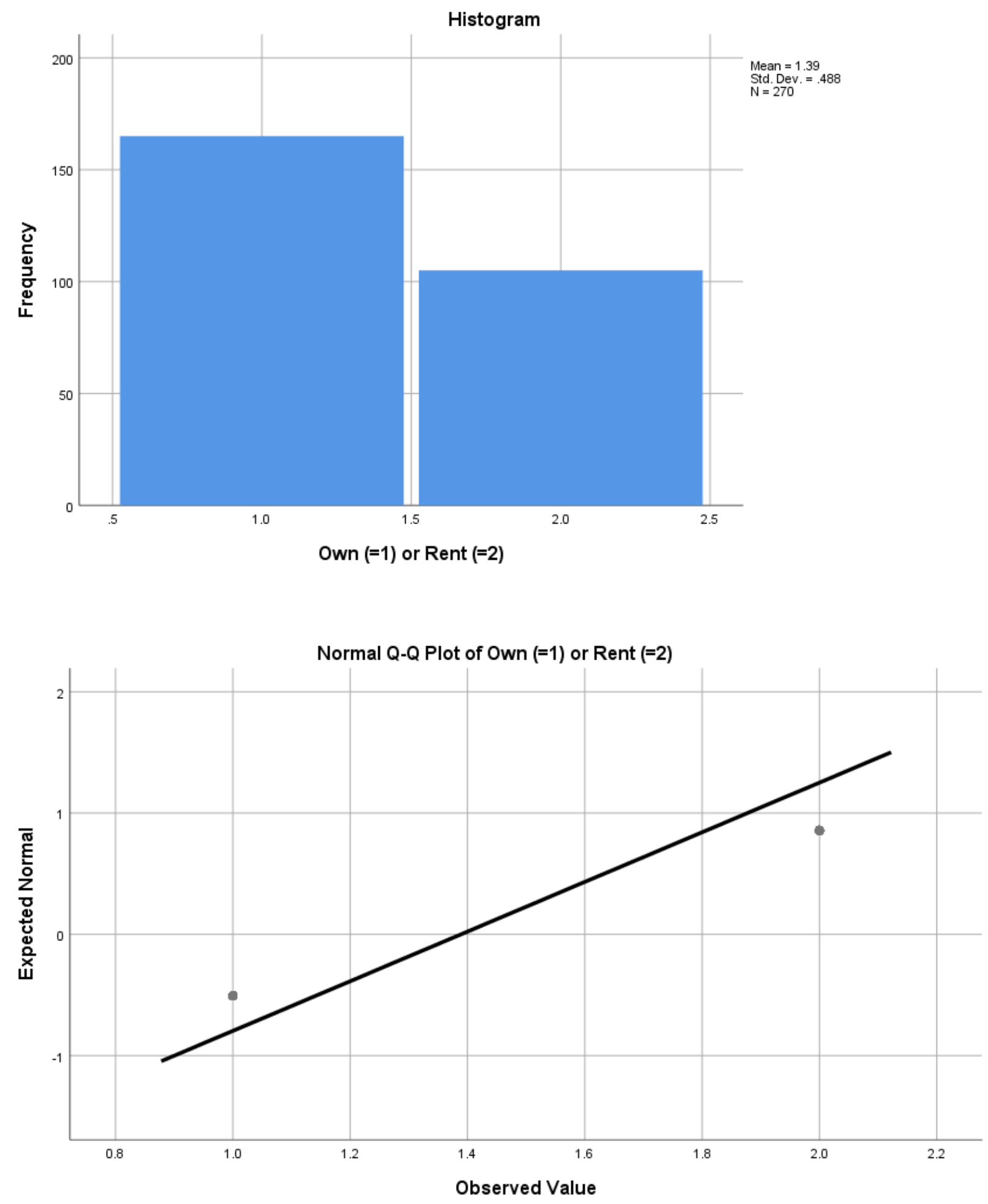


\section{Building Type (House=1, Condominium/Apartment=2)}
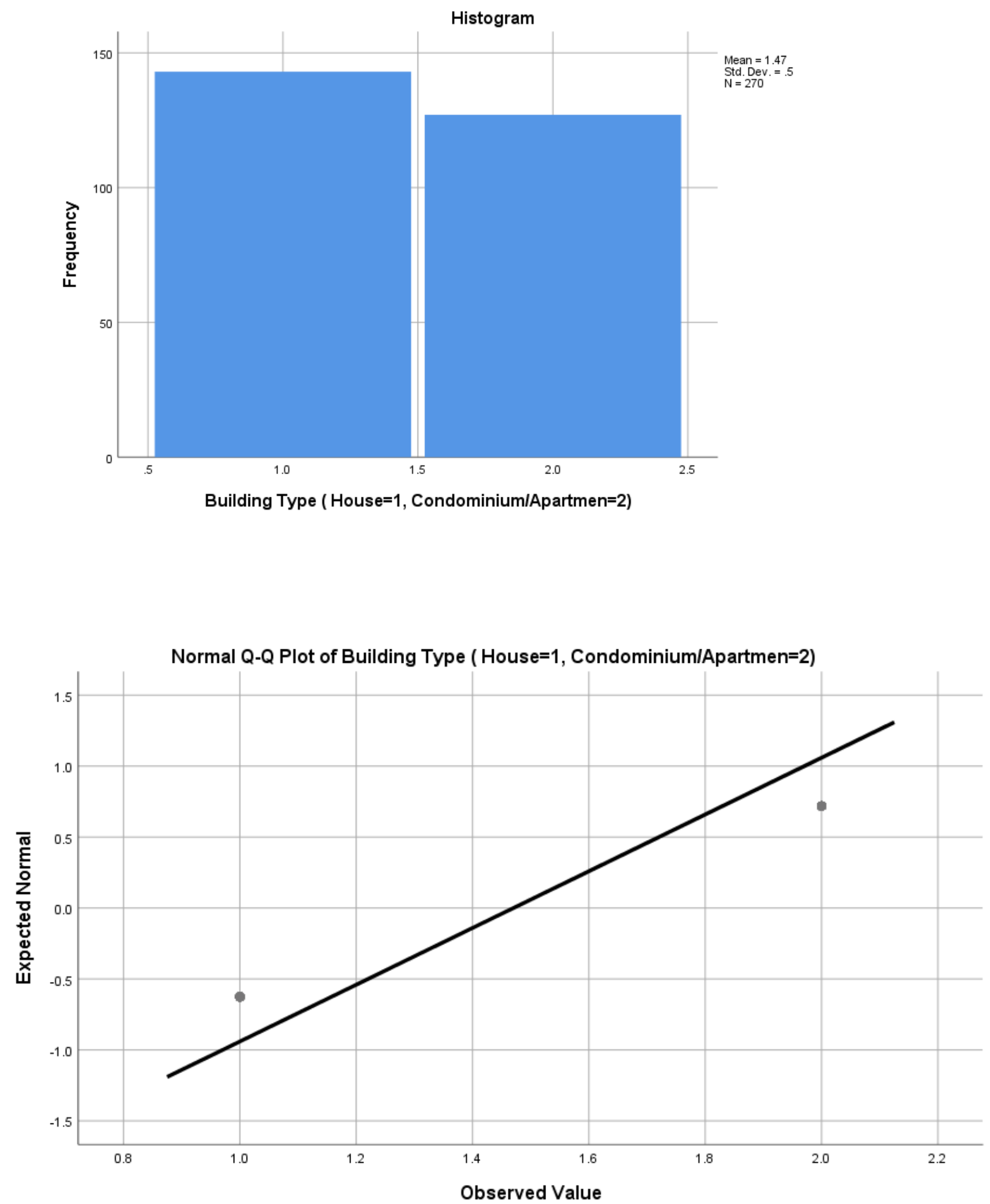
How frequently do you experience blackouts of more than an hour?

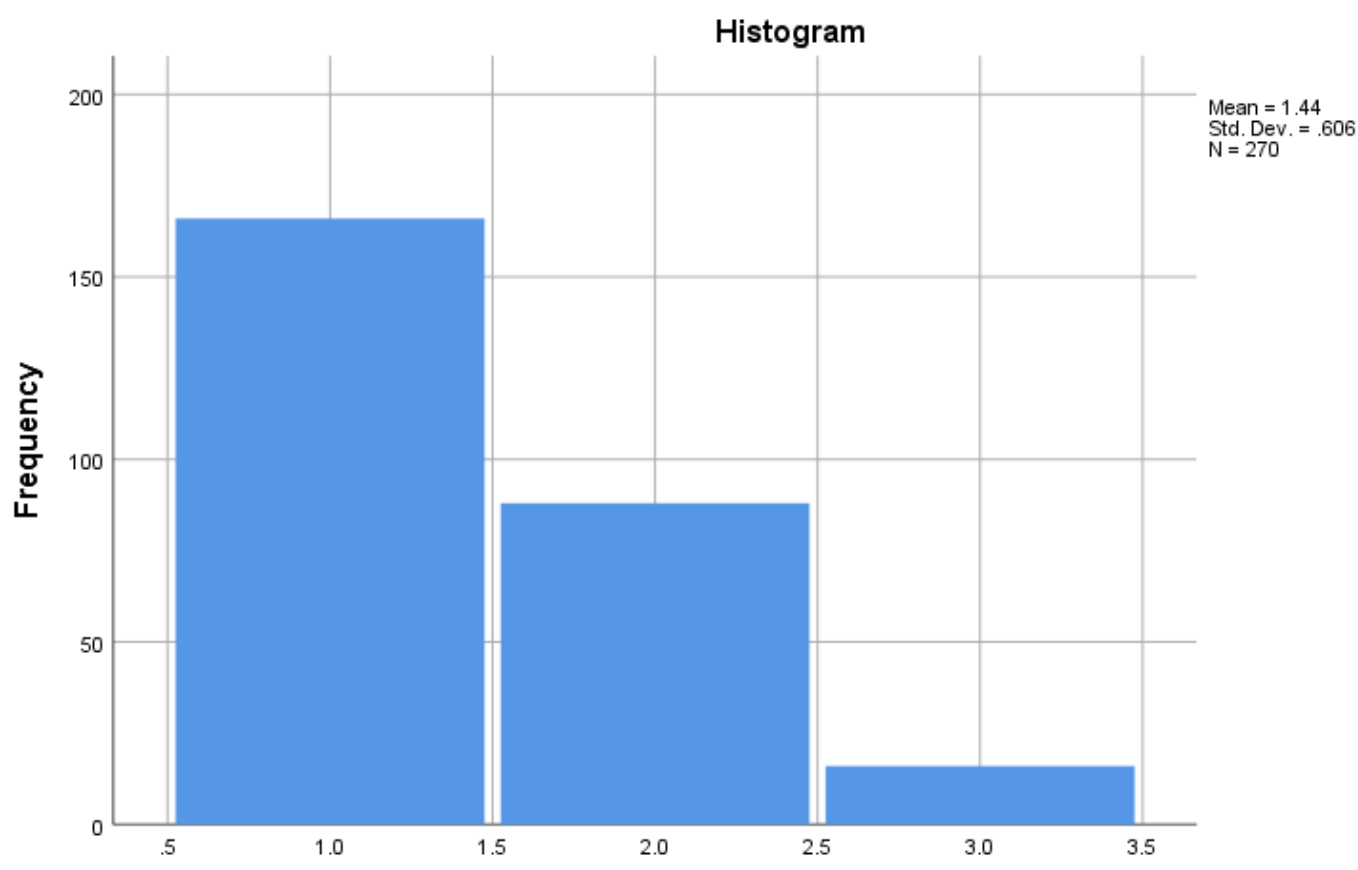

How frequently do you experience blackouts of more than an hour?

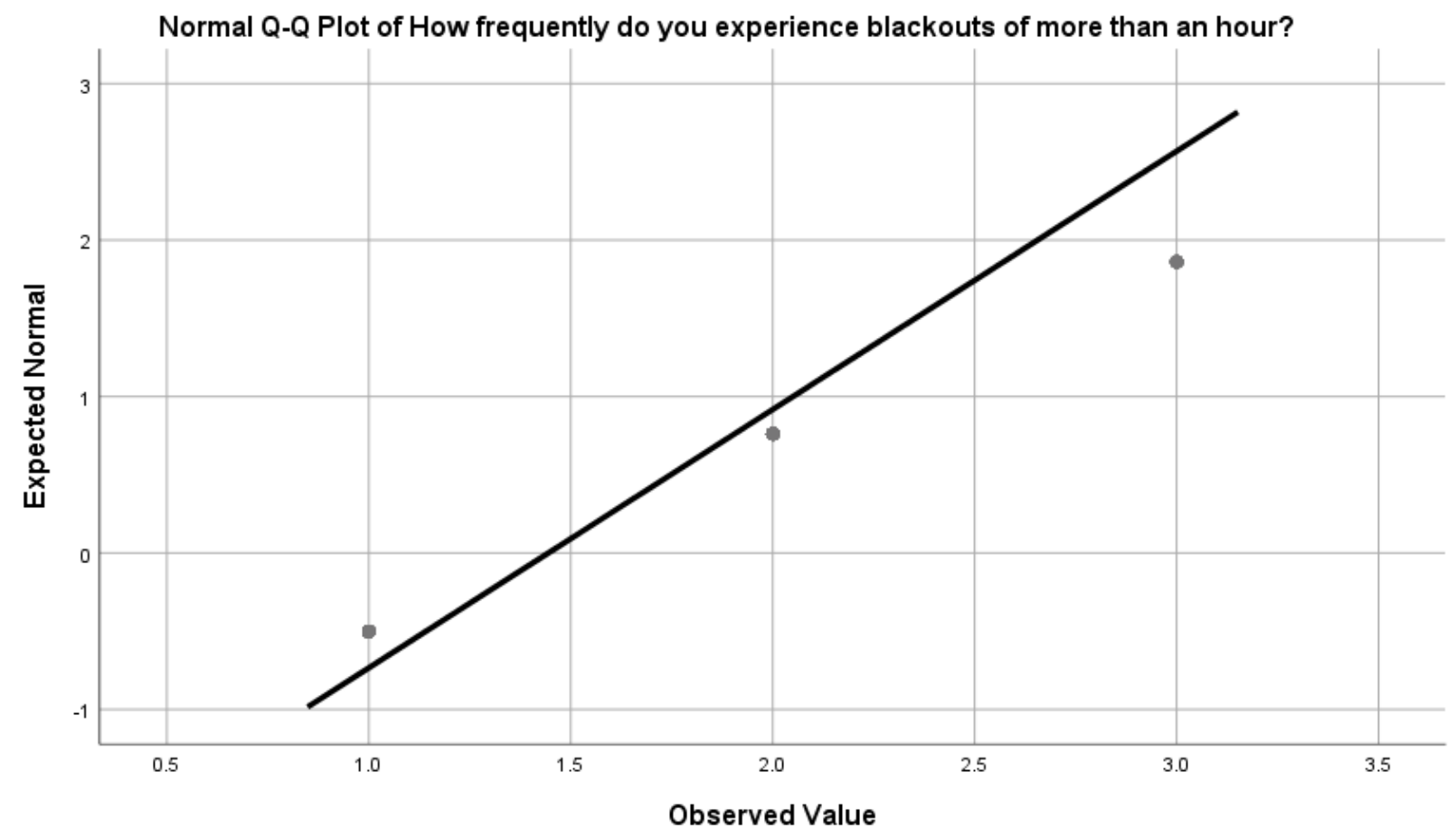




\section{I care about the environment.}

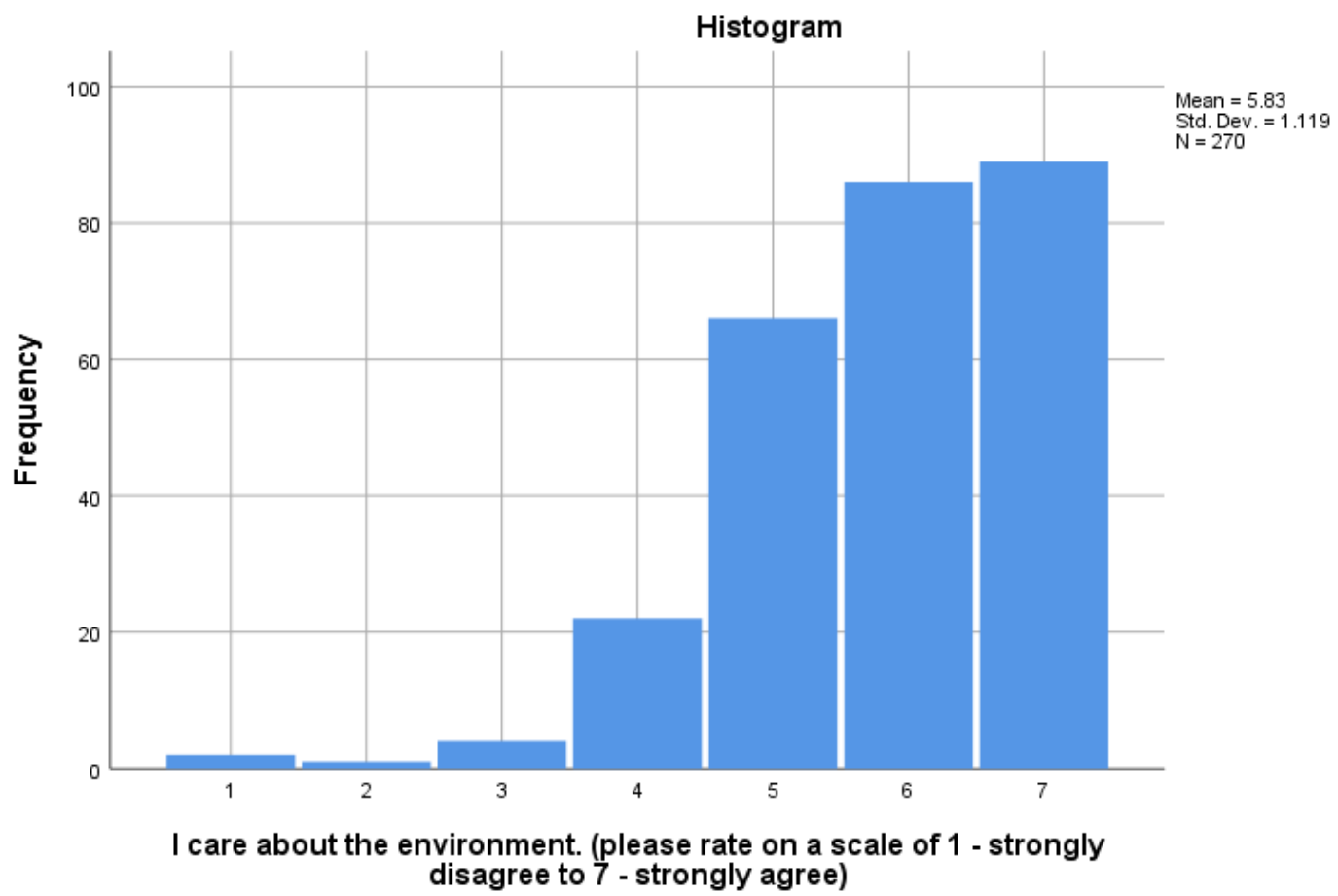

Normal Q-Q Plot of I care about the environment. (please rate on a scale of 1 - strongly disagree to 7 - strongly

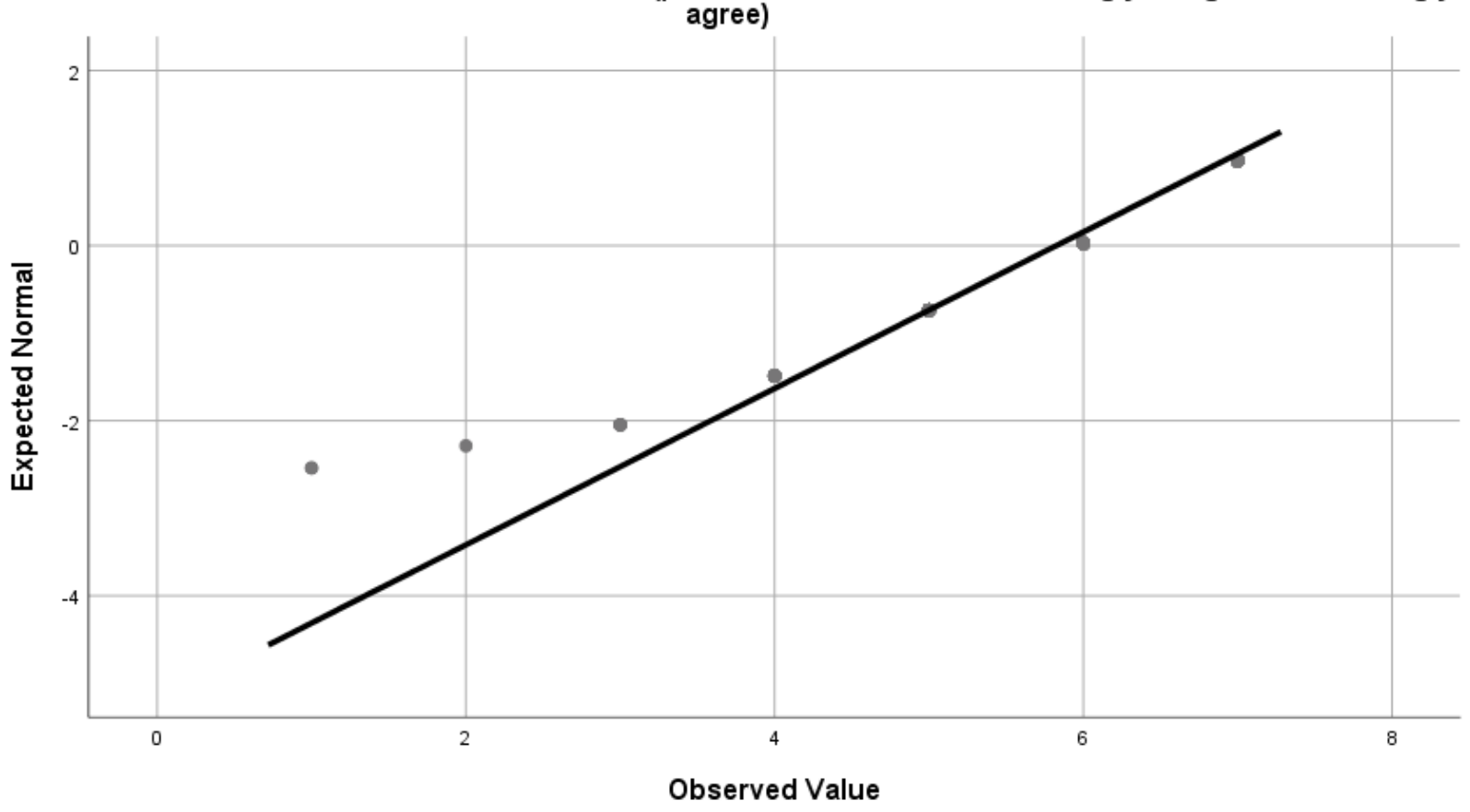


I have a good understanding of the concept of local community energy (please rate on a scale of 1 - strongly disagree to 7 - strongly agree)

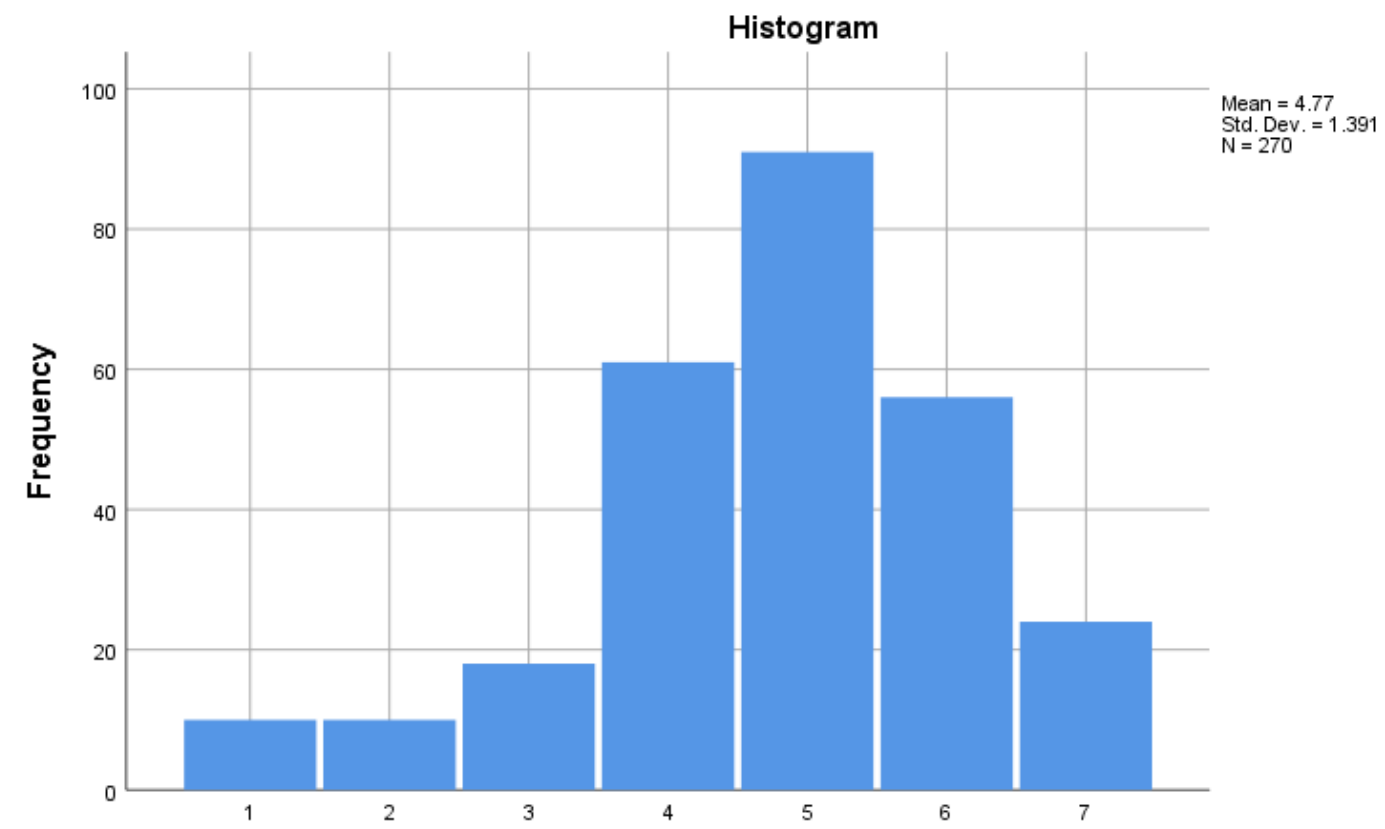

I have a good understanding of the concept of local community energy (please rate on a scale of 1 - strongly disagree to 7 - strongly agree)

Normal Q-Q Plot of I have a good understanding of the concept of local community energy (please rate on a

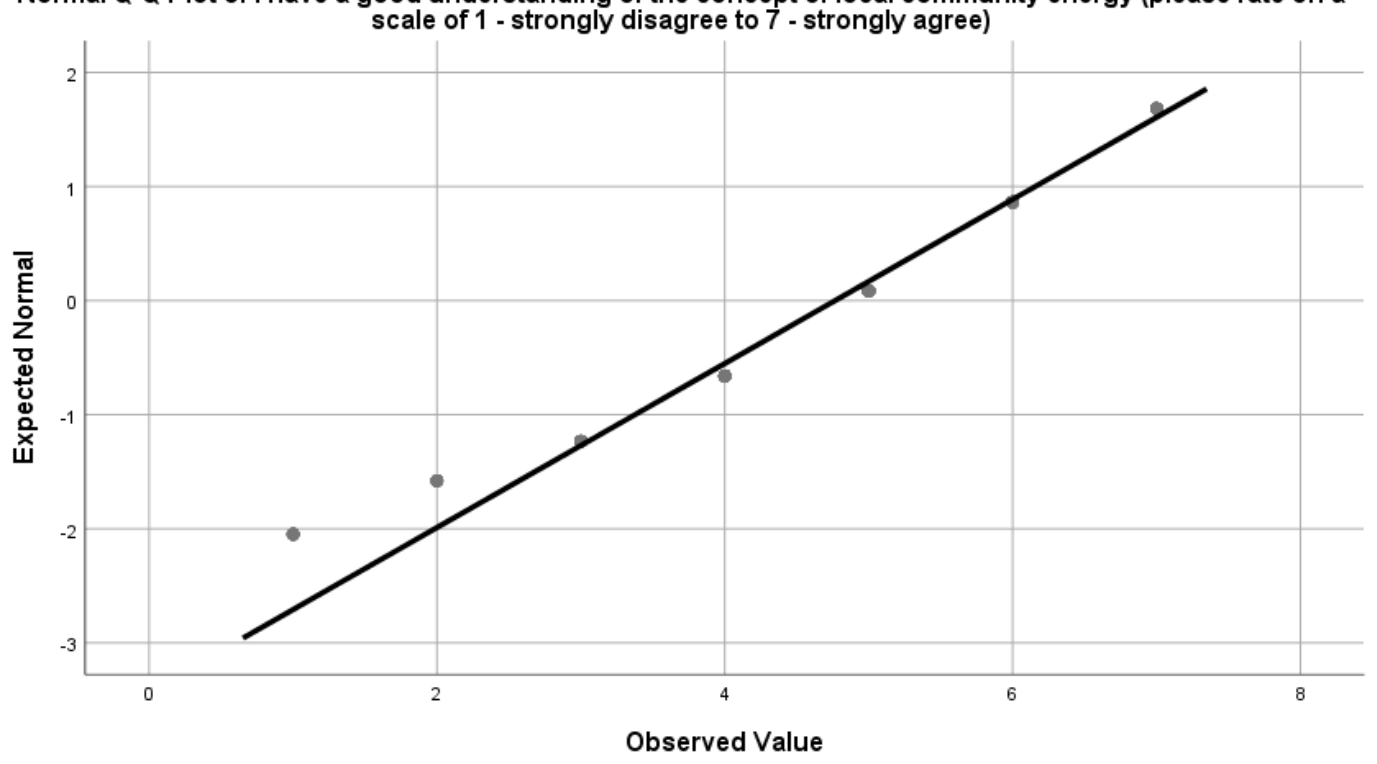




\section{I feel strongly attached to the community I live in and I participate in community activities. (Please rate on a scale of 1 - strongly disagree to 7 - strongly agree)}

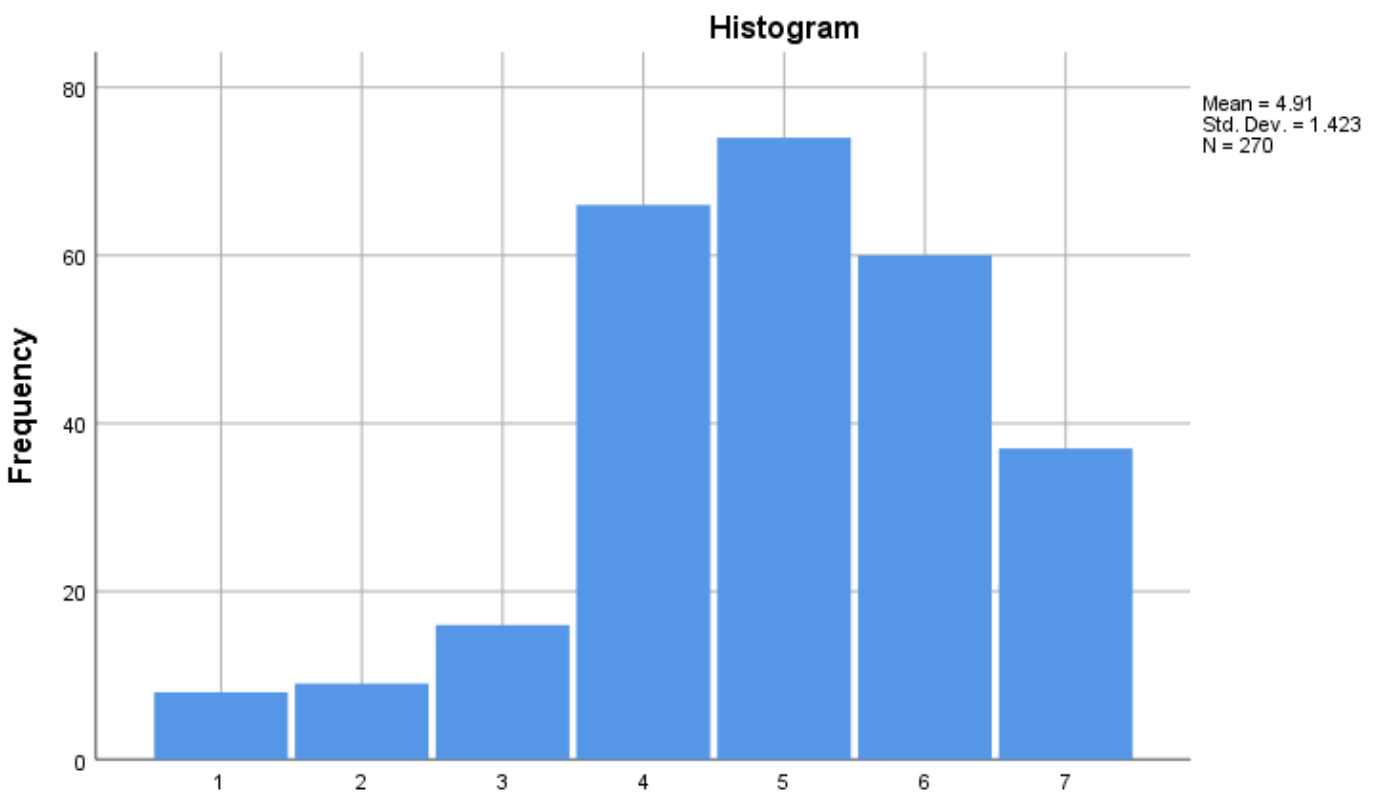

I feel strongly attached to the community I live in and I participate in community activities. (please rate on a scale of 1 - strongly disagree to 7 strongly agree)

Normal Q-Q Plot of I feel strongly attached to the community I live in and I participate in community activities.

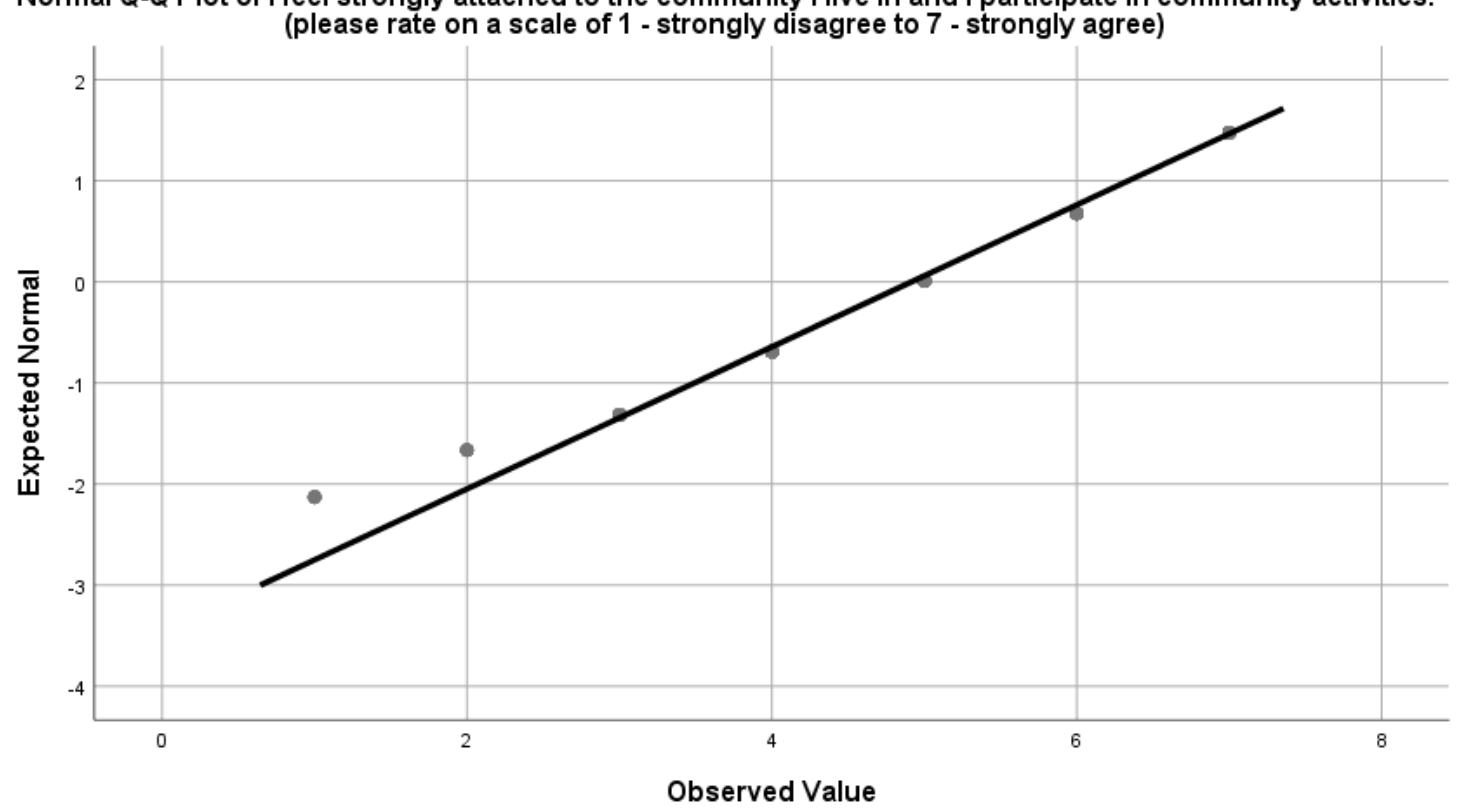


I would like to see renewable energy produced for local use in my community (please rate on a scale of 1 - strongly disagree to 7 - strongly agree)

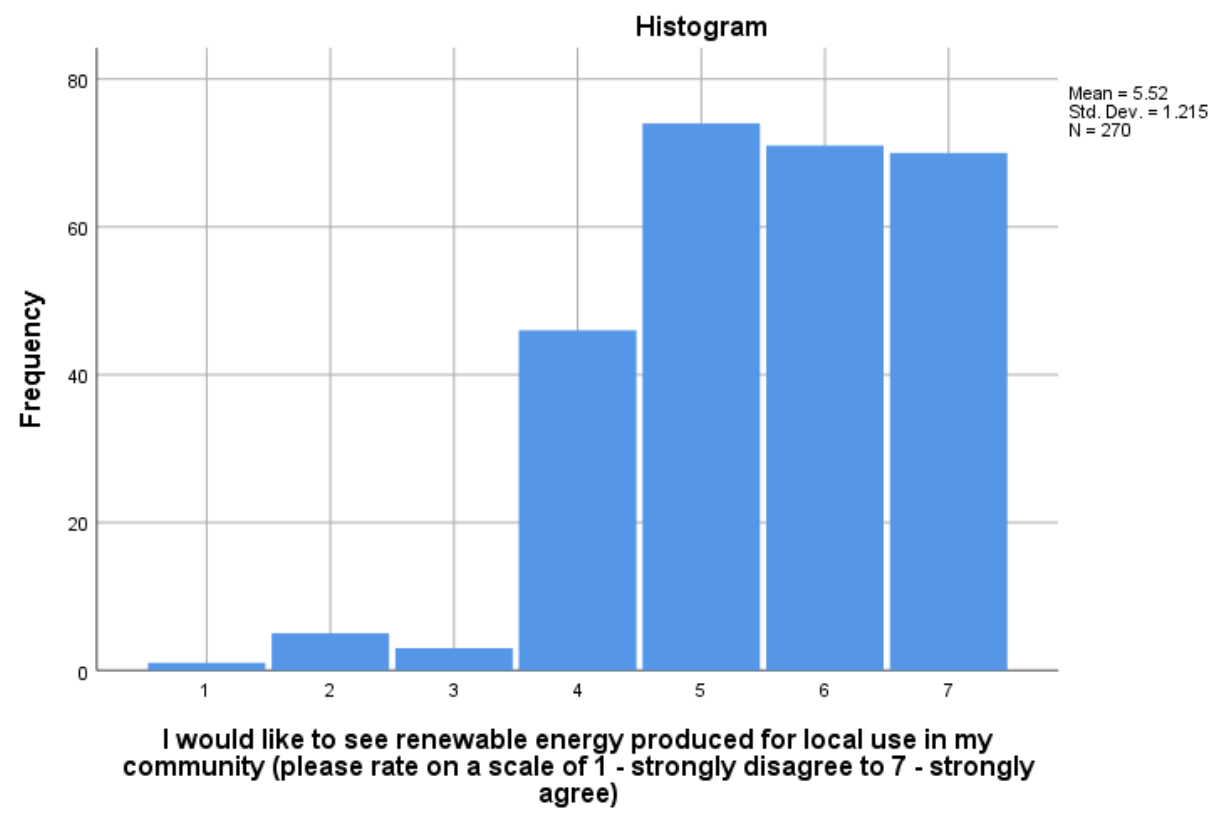

Normal Q-Q Plot of I would like to see renewable energy produced for local use in my community (please rate on a scale of 1 - strongly disagree to 7 - strongly agree)

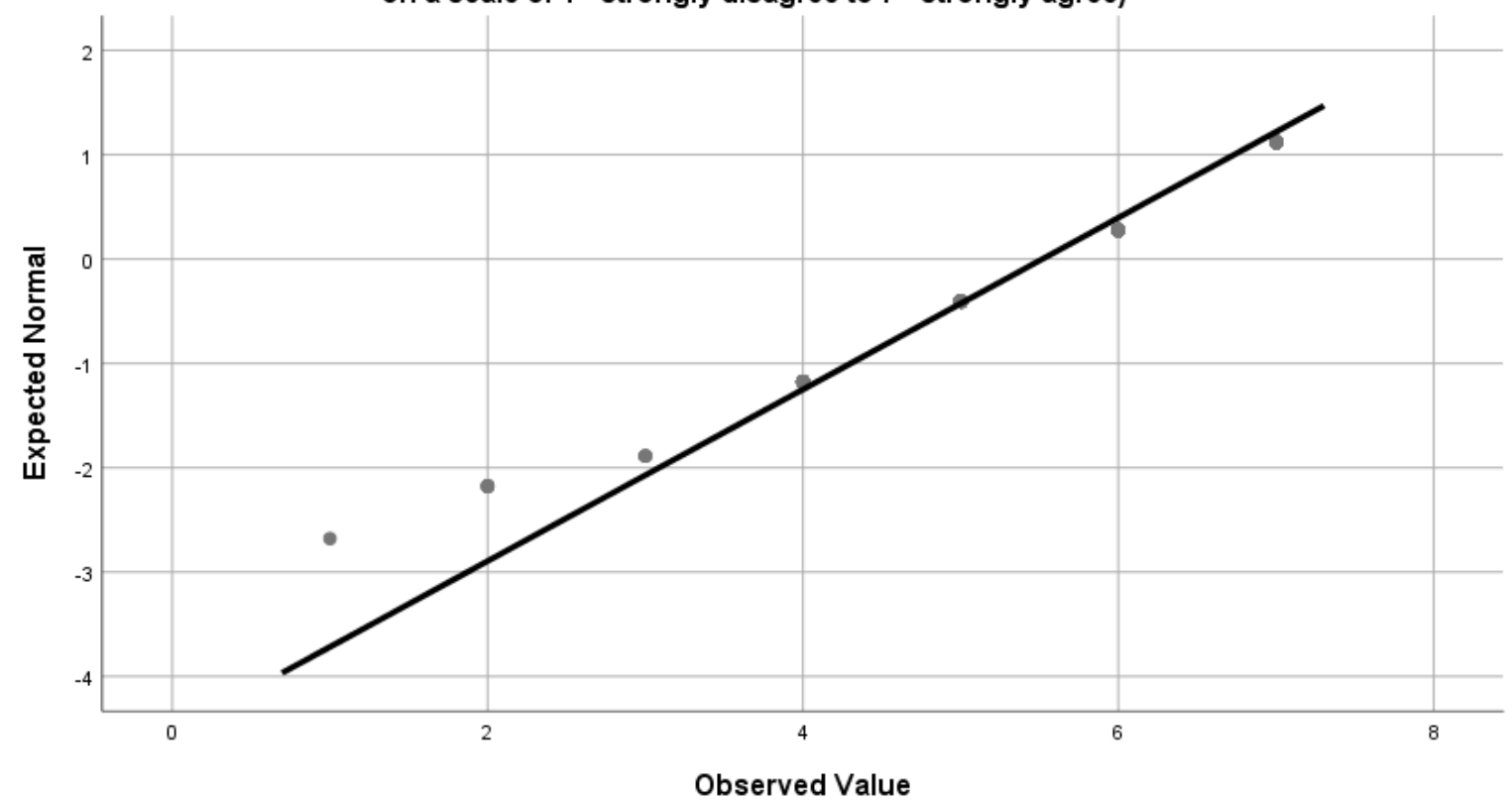


How likely are you to lead and organise a local community energy project?
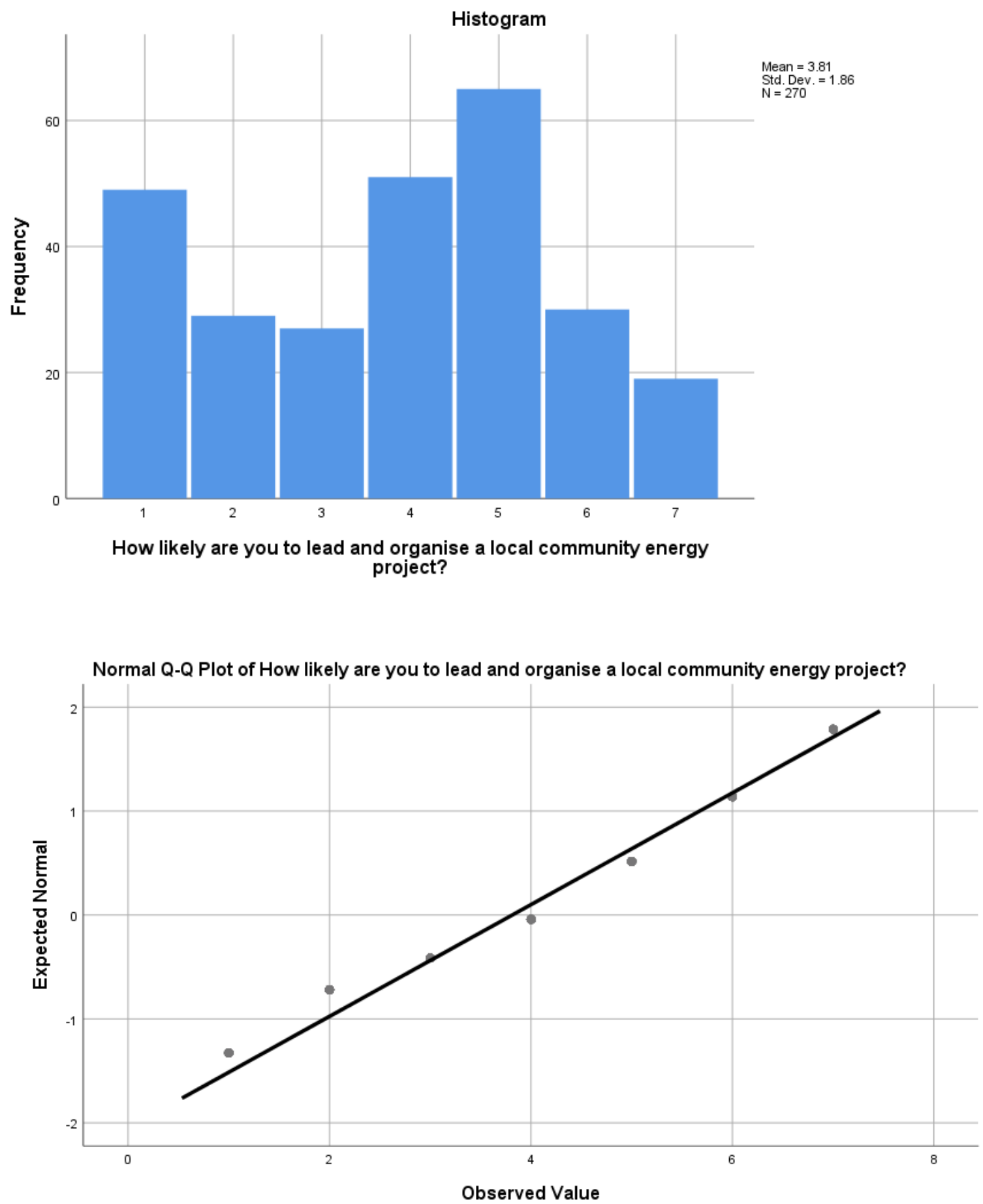
How likely are you to contribute financially and invest money in a local community energy project?

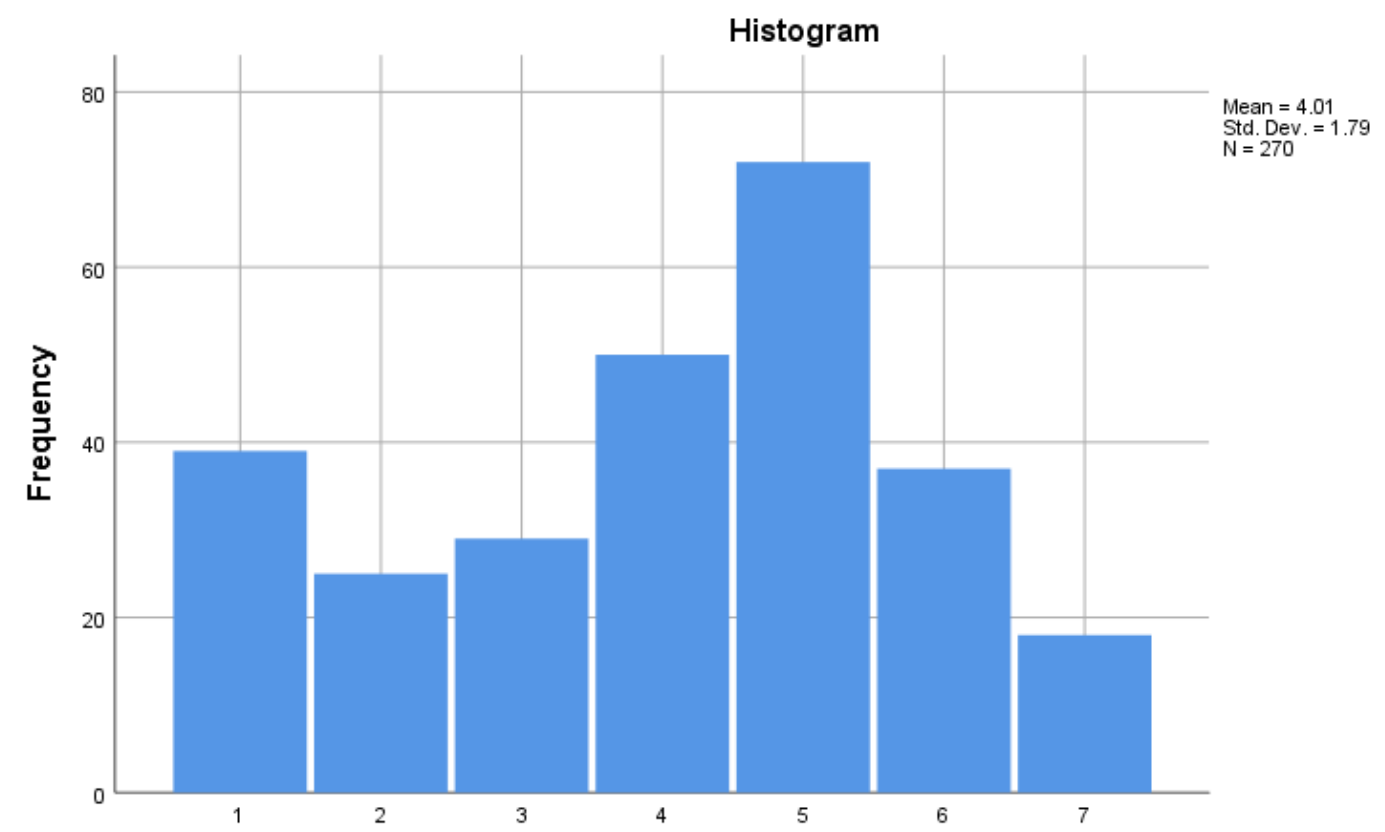

How likely are you to contribute financially and invest money in a local community energy project?

Normal Q-Q Plot of How likely are you to contribute financially and invest money in a local community energy

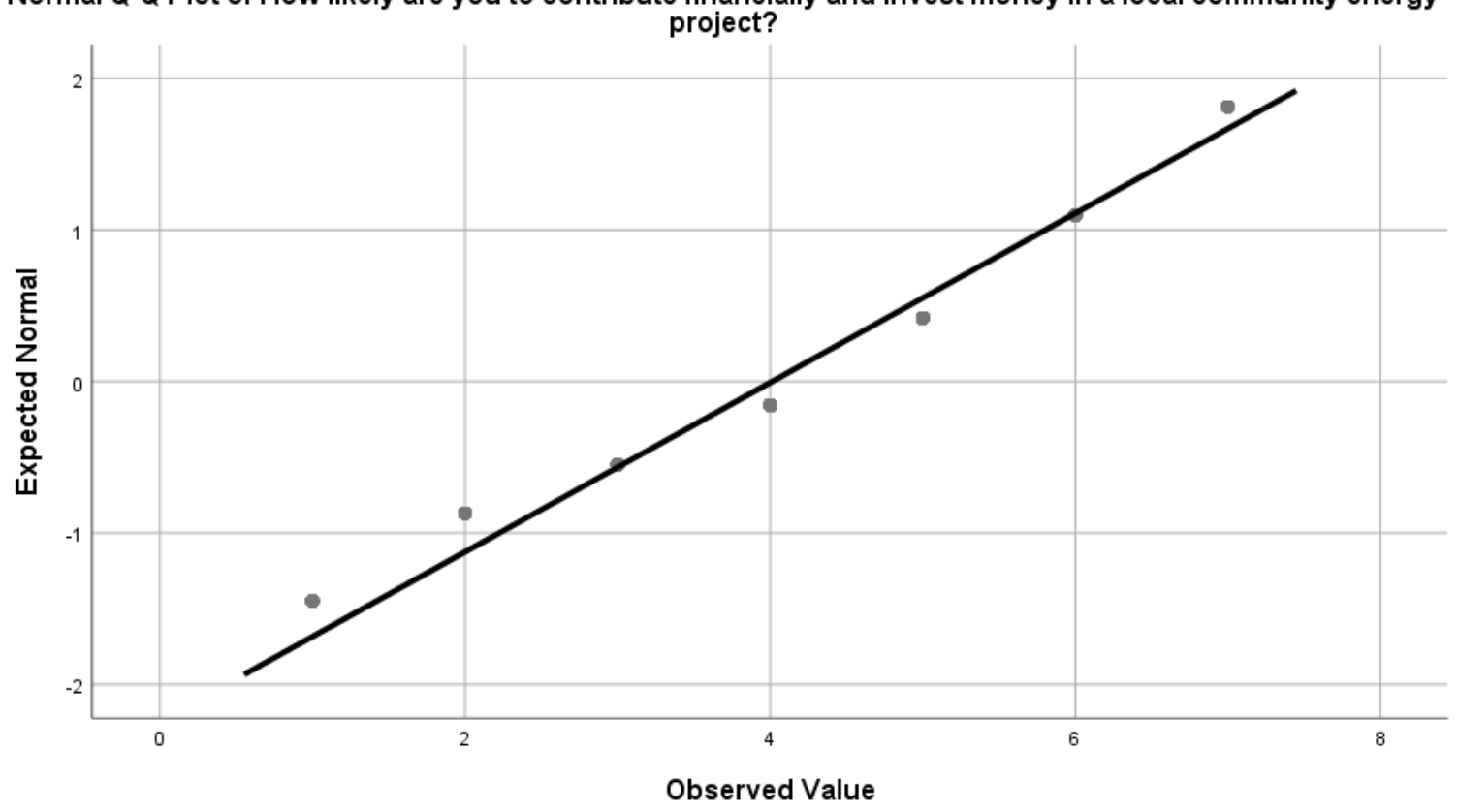


My ideal level of participation in a local community energy project is (1= Low, 2= Medium, 3=High)

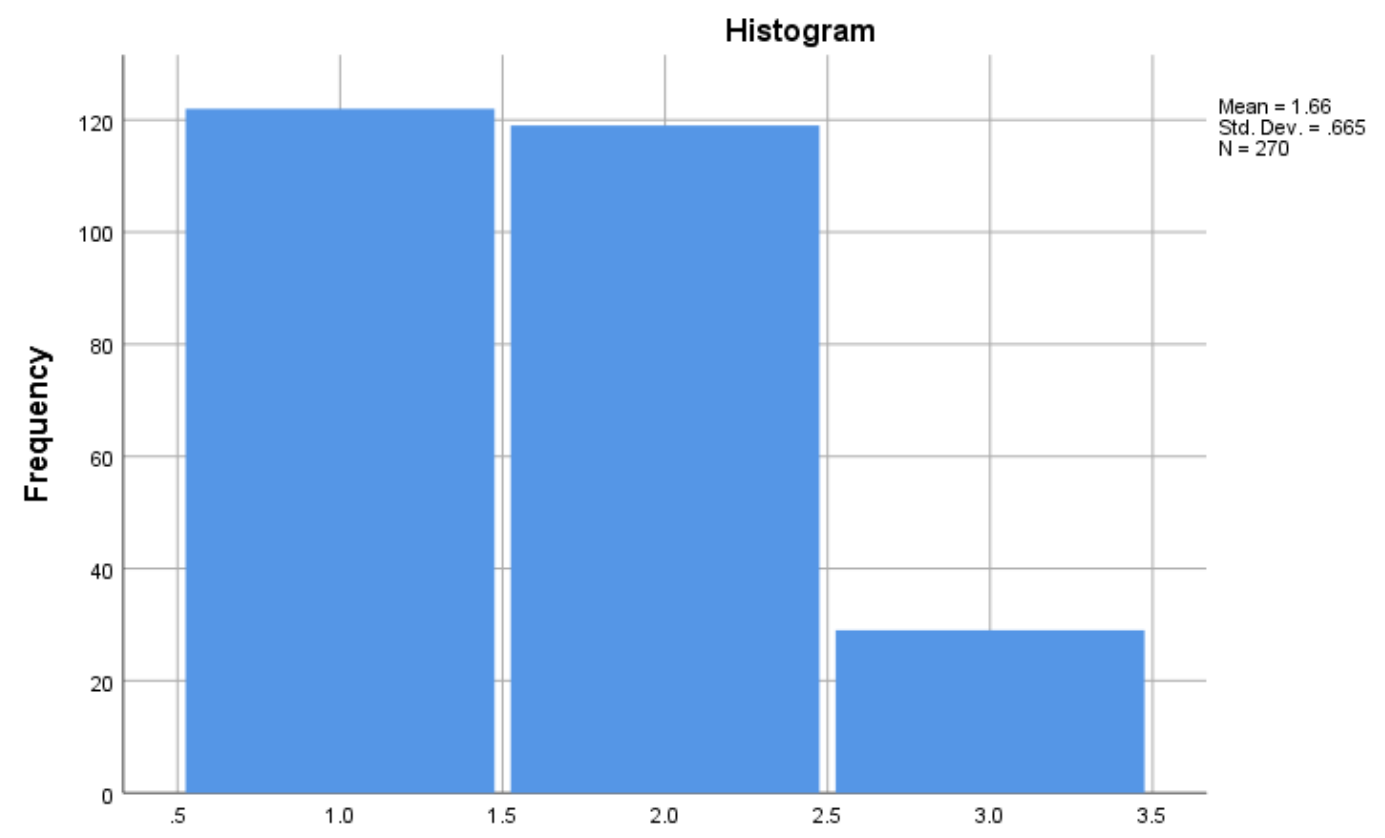

My ideal level of participation in a local community energy project is (1= Low, 2= Medium, 3=High)

Normal Q-Q Plot of My ideal level of participation in a local community energy project is (1= Low, $2=$ Medium,

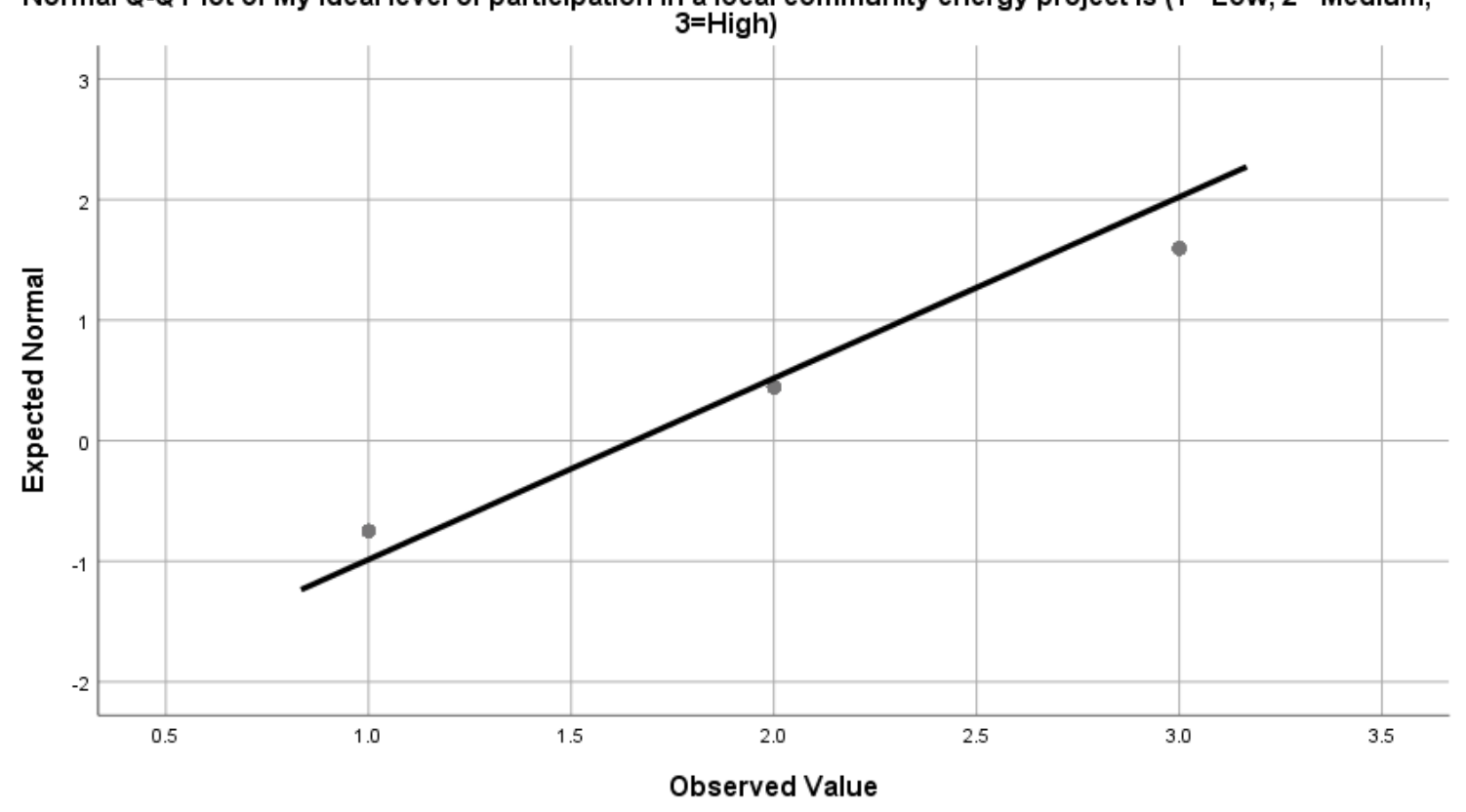


How interested are you in owning a part of (such as few solar panels in a solar farm) a bigger local community energy project led by a developer?

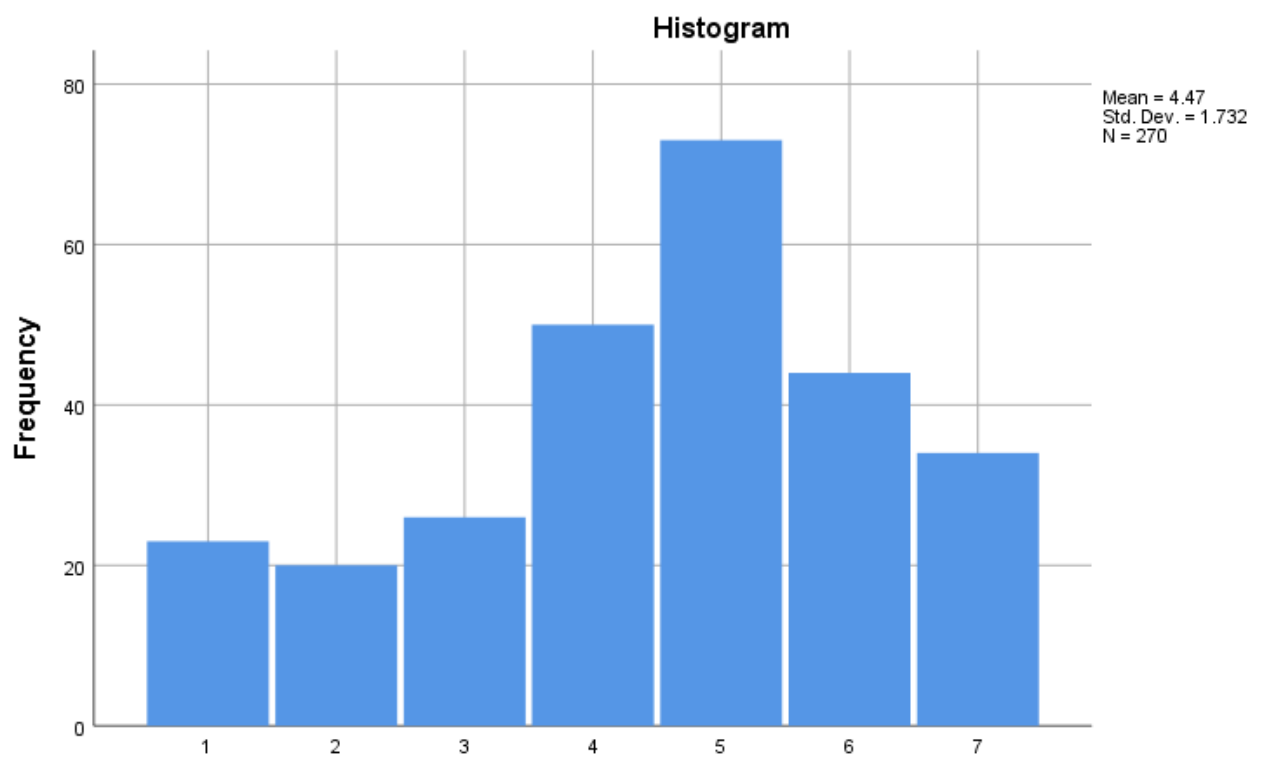

How interested are you in owning a part of (such as few solar panels in a solar farm) a bigger local community energy project led by a developer?

Normal Q-Q Plot of How interested are you in owning a part of (such as few solar panels in a solar farm) a bigger local community energy project led by a developer?

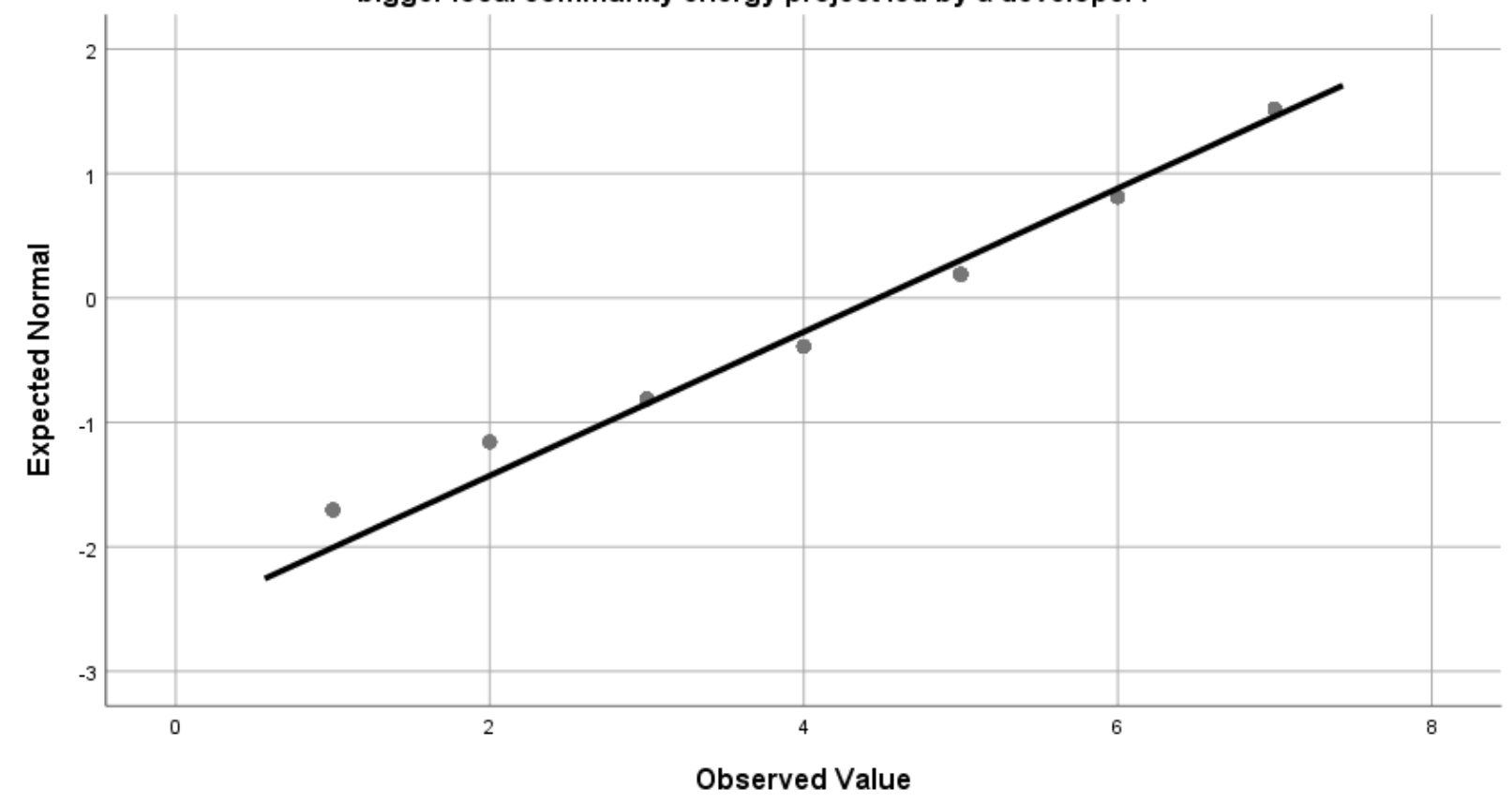


How likely are you to produce energy and sell it to your neighbour?

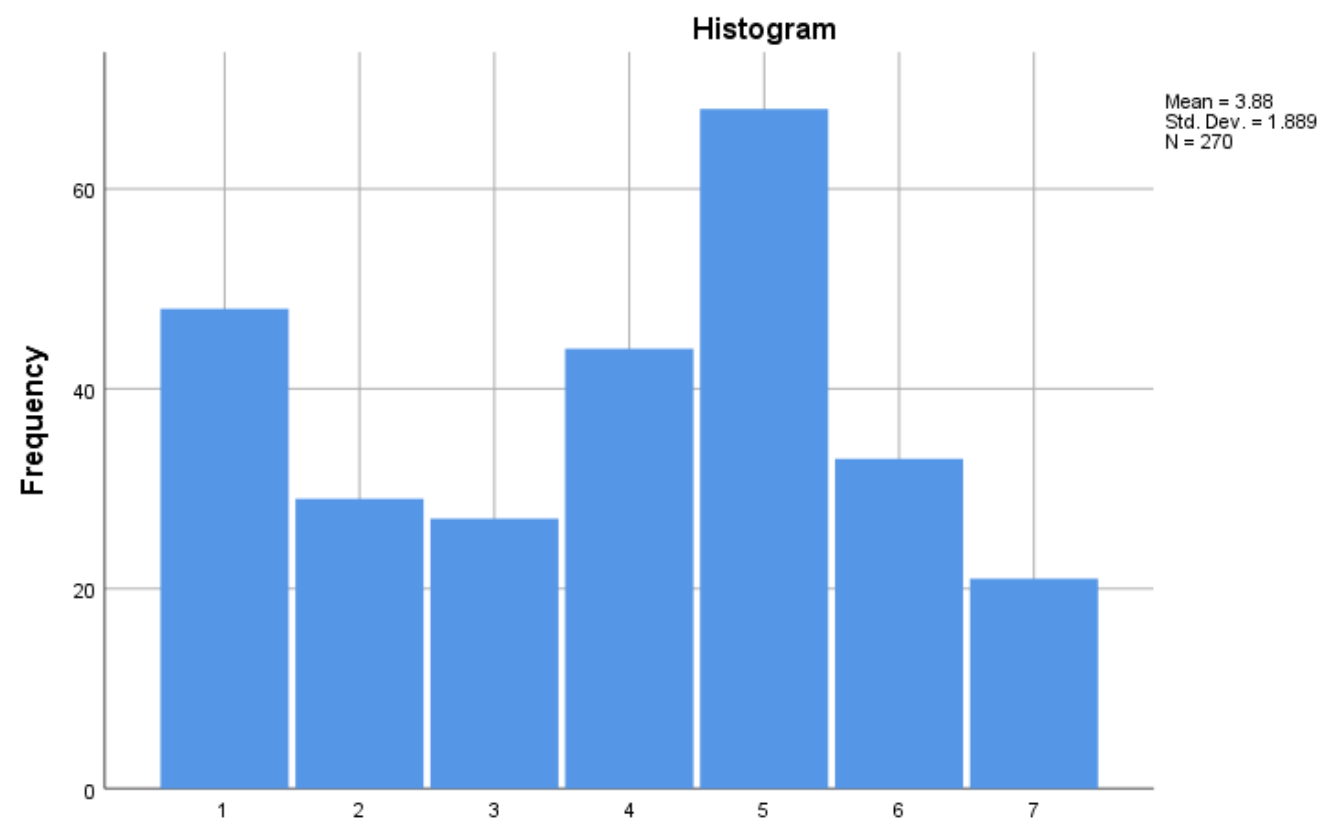

How likely are you to produce energy and sell it to your neighbor?

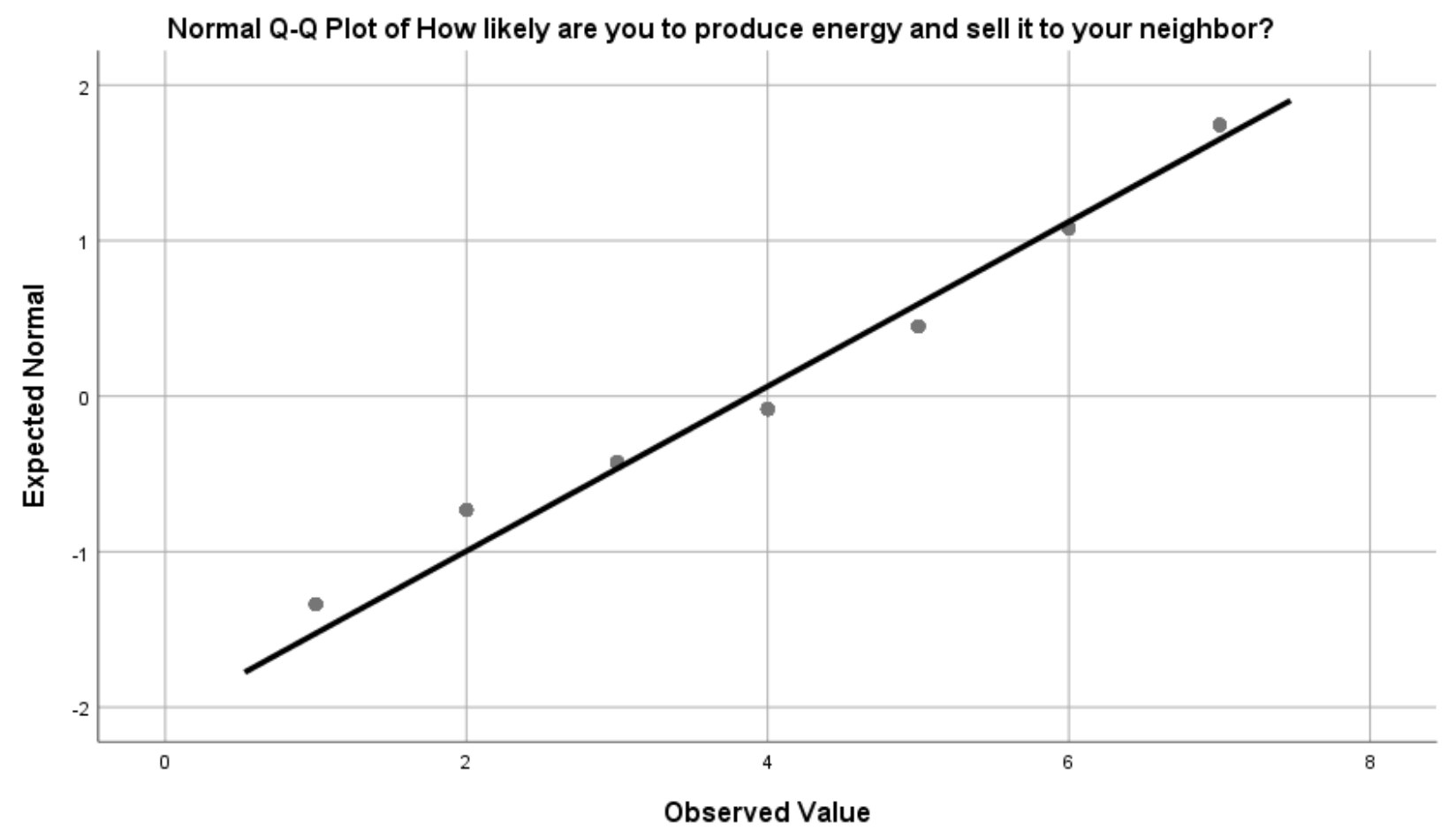


How likely are you to buy energy from your neighbour/local community energy project?

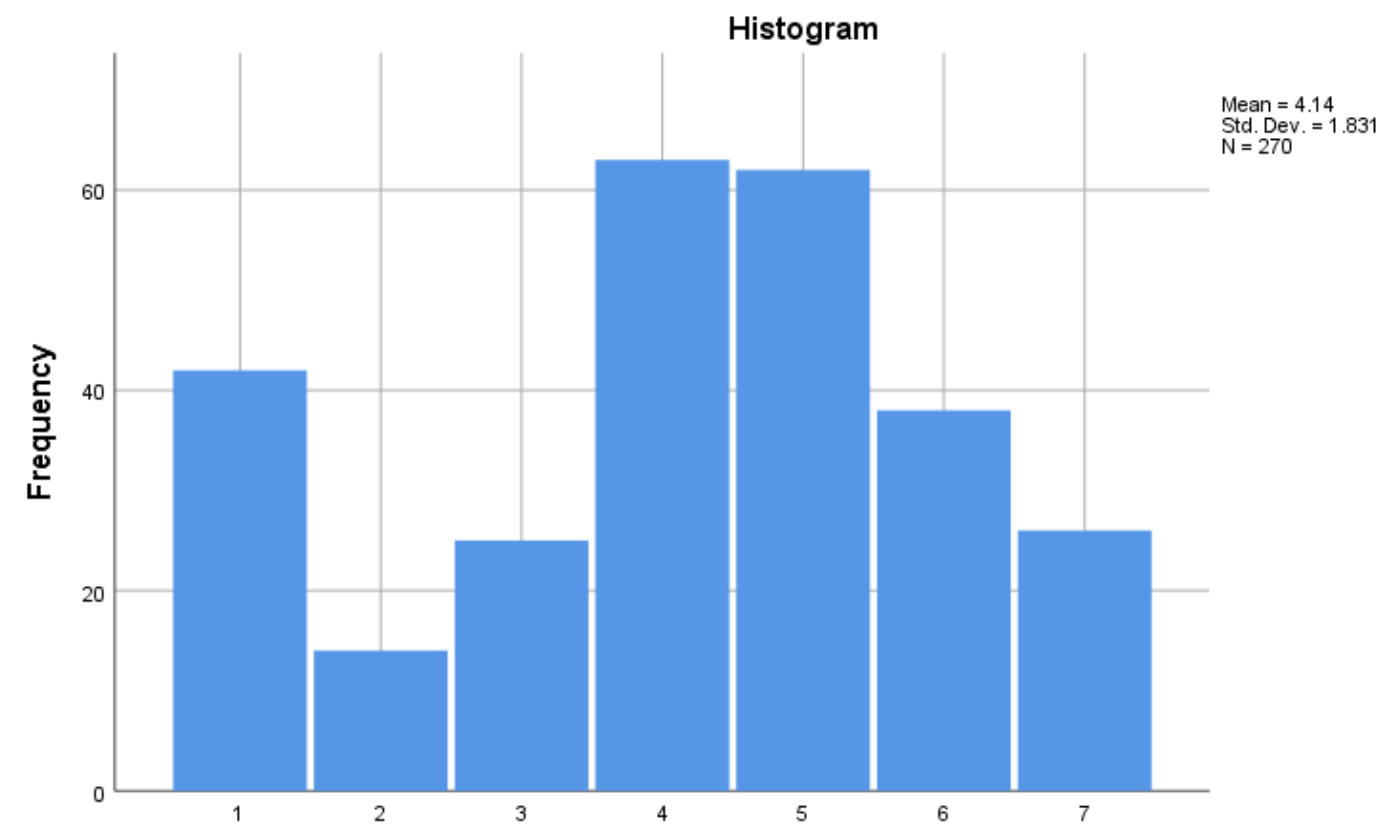

How likely are you to buy energy from your neighbour/local community energy project?

Normal Q-Q Plot of How likely are you to buy energy from your neighbour/local community energy project?

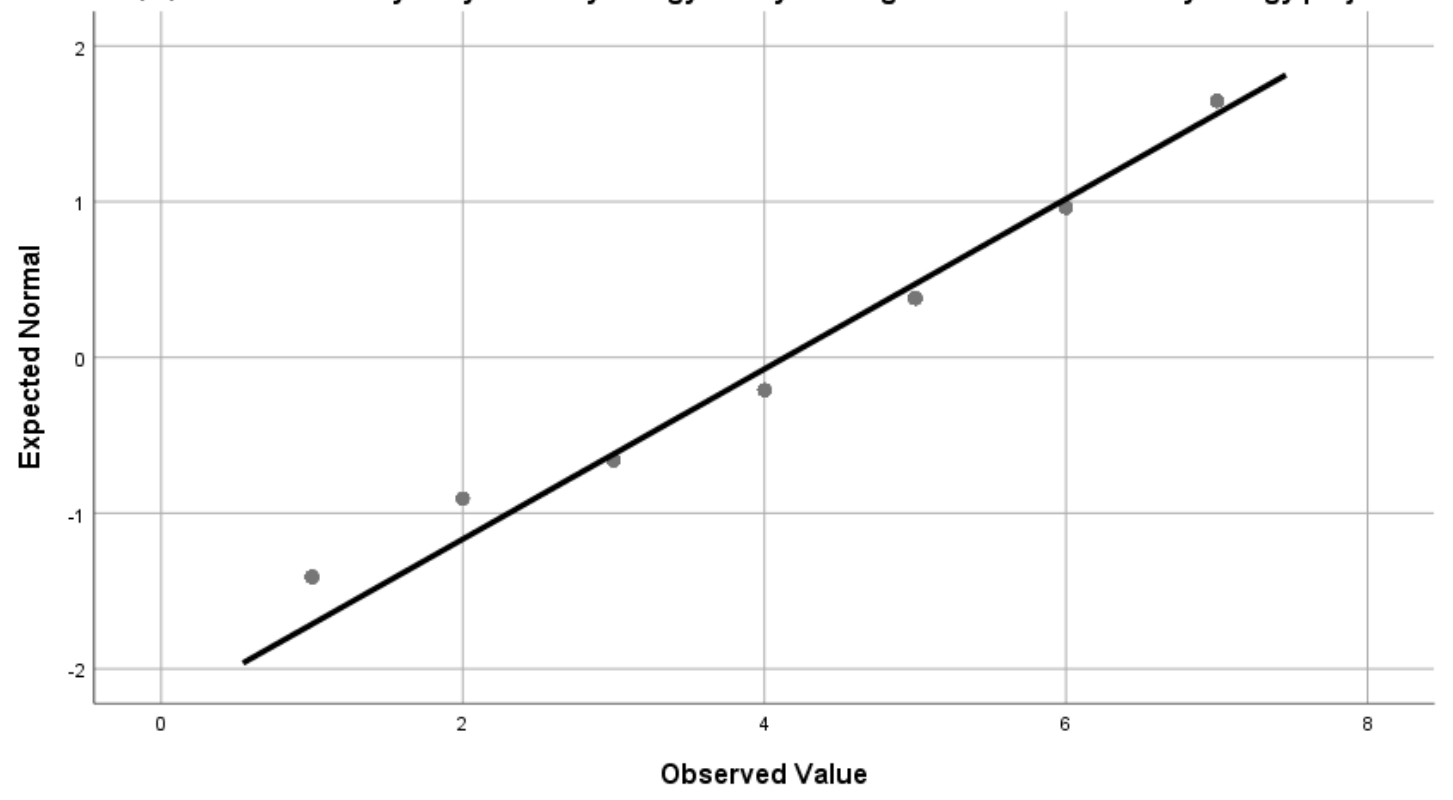


How likely are you to buy energy from a local community energy project or your neighbour even if it were more expensive than utility provided electricity?

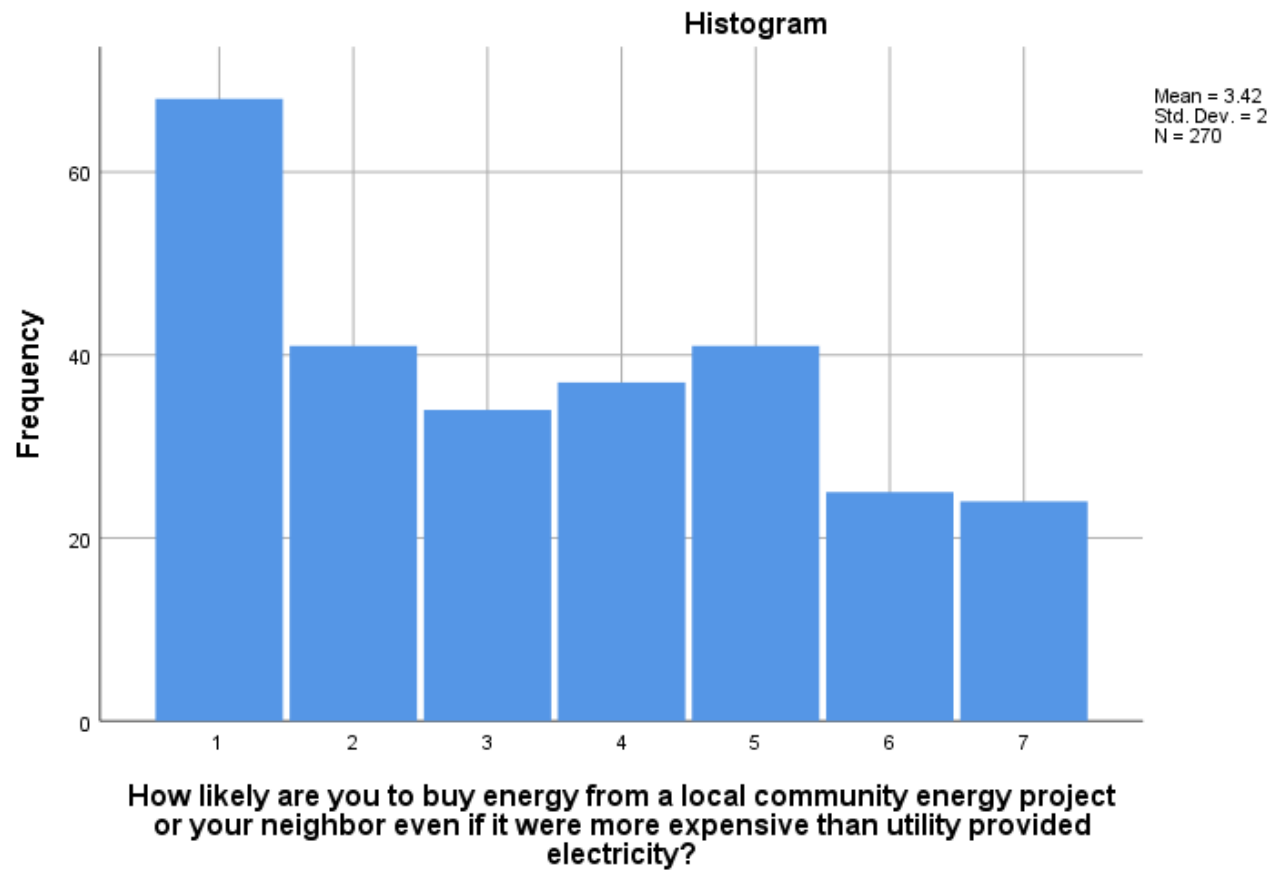

Normal Q-Q Plot of How likely are you to buy energy from a local community energy project or your neighbor

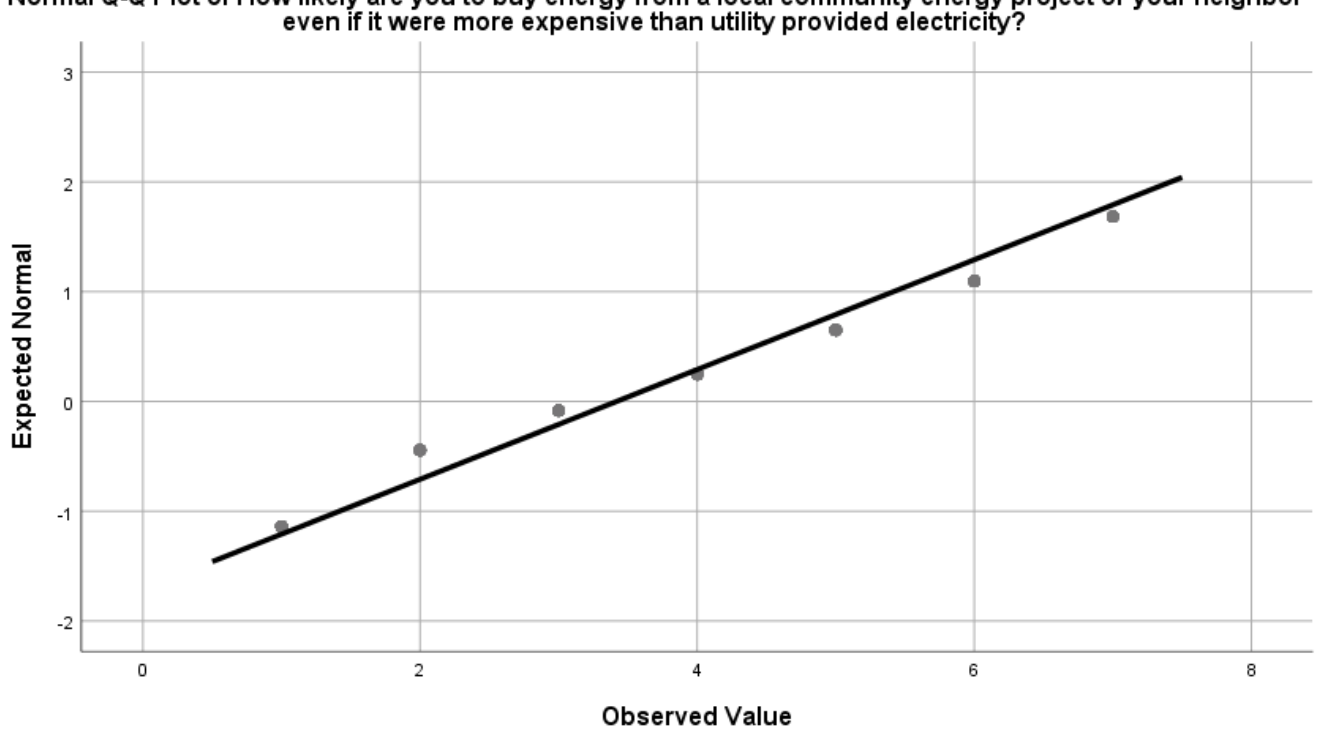


How likely are you to participate in a local community energy project if your neighbours/friends are participating?

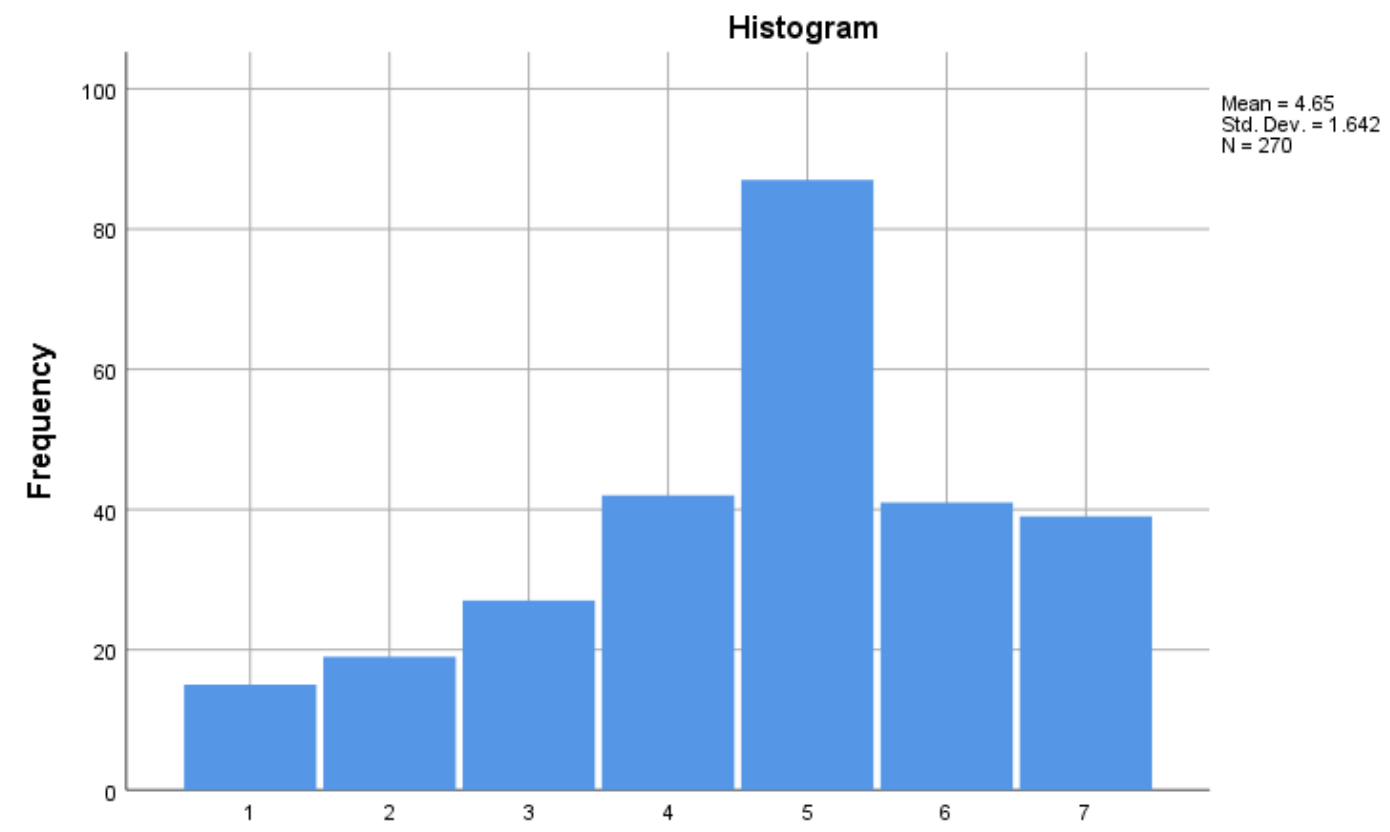

How likely are you to participate in a local community energy project if your neighbors/friends are participating?

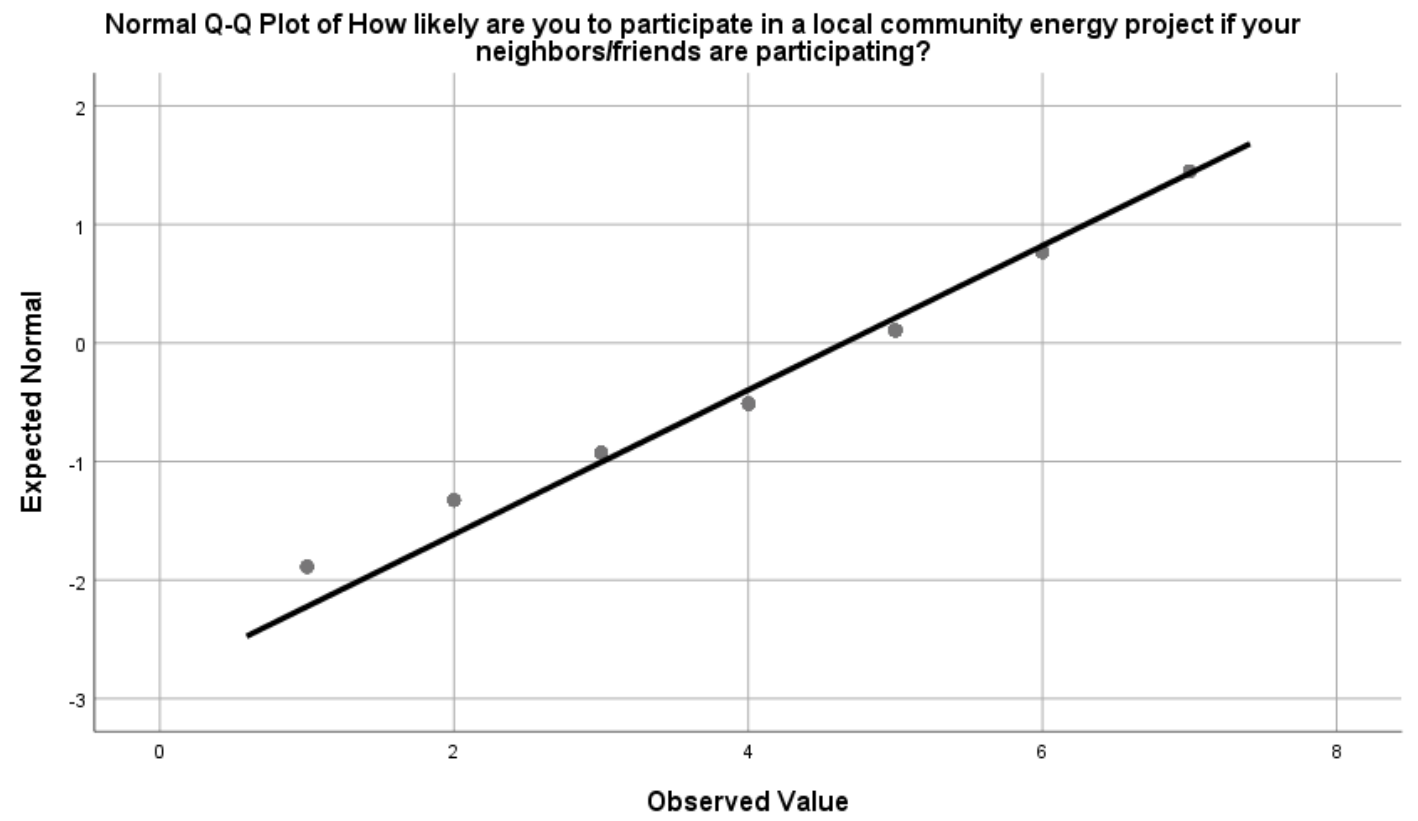


How concerned are you about local energy generation (such as solar panels) impacting property value?

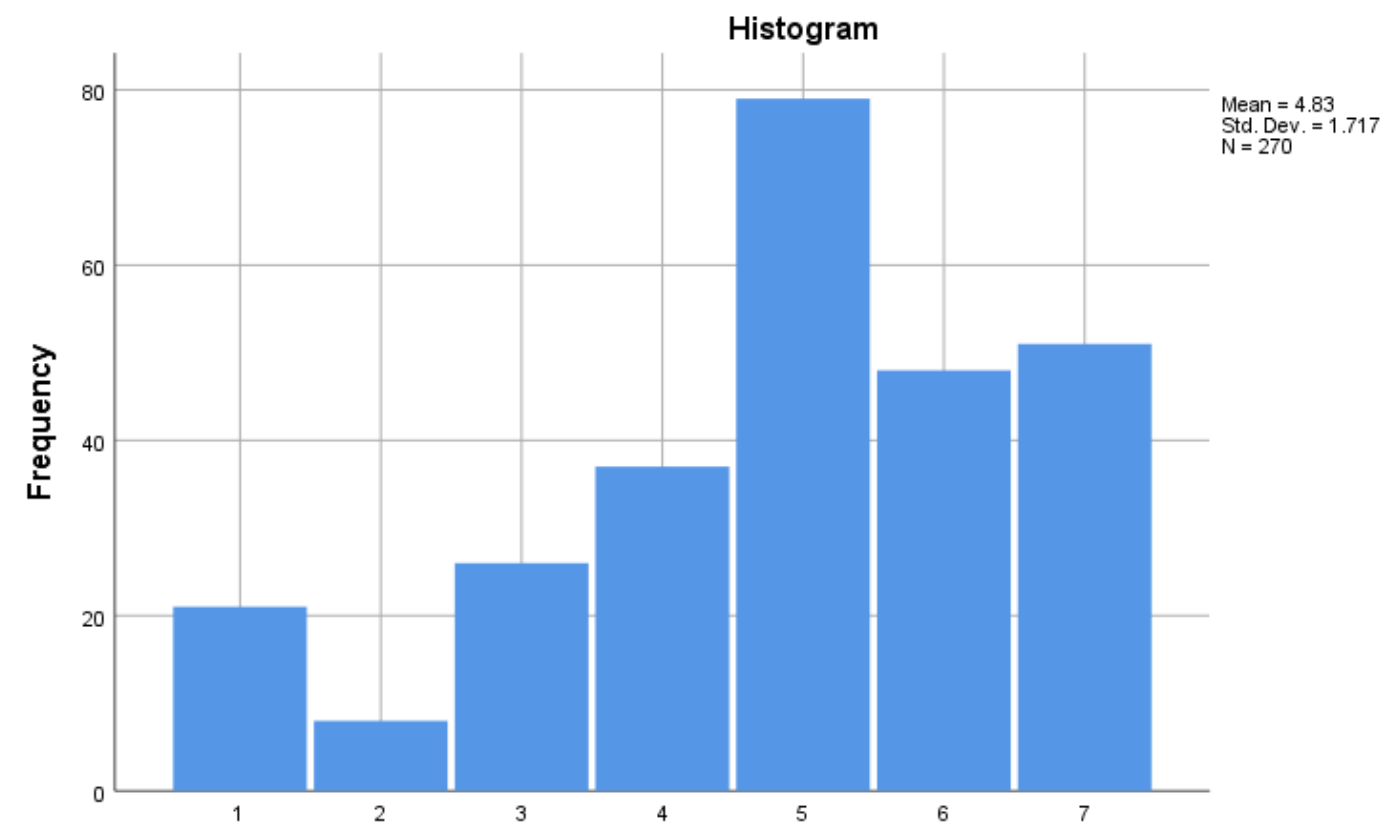

How concerned are you about local energy generation (such as solar panels) impacting property value?

Normal Q-Q Plot of How concerned are you about local energy generation (such as solar panels) impacting

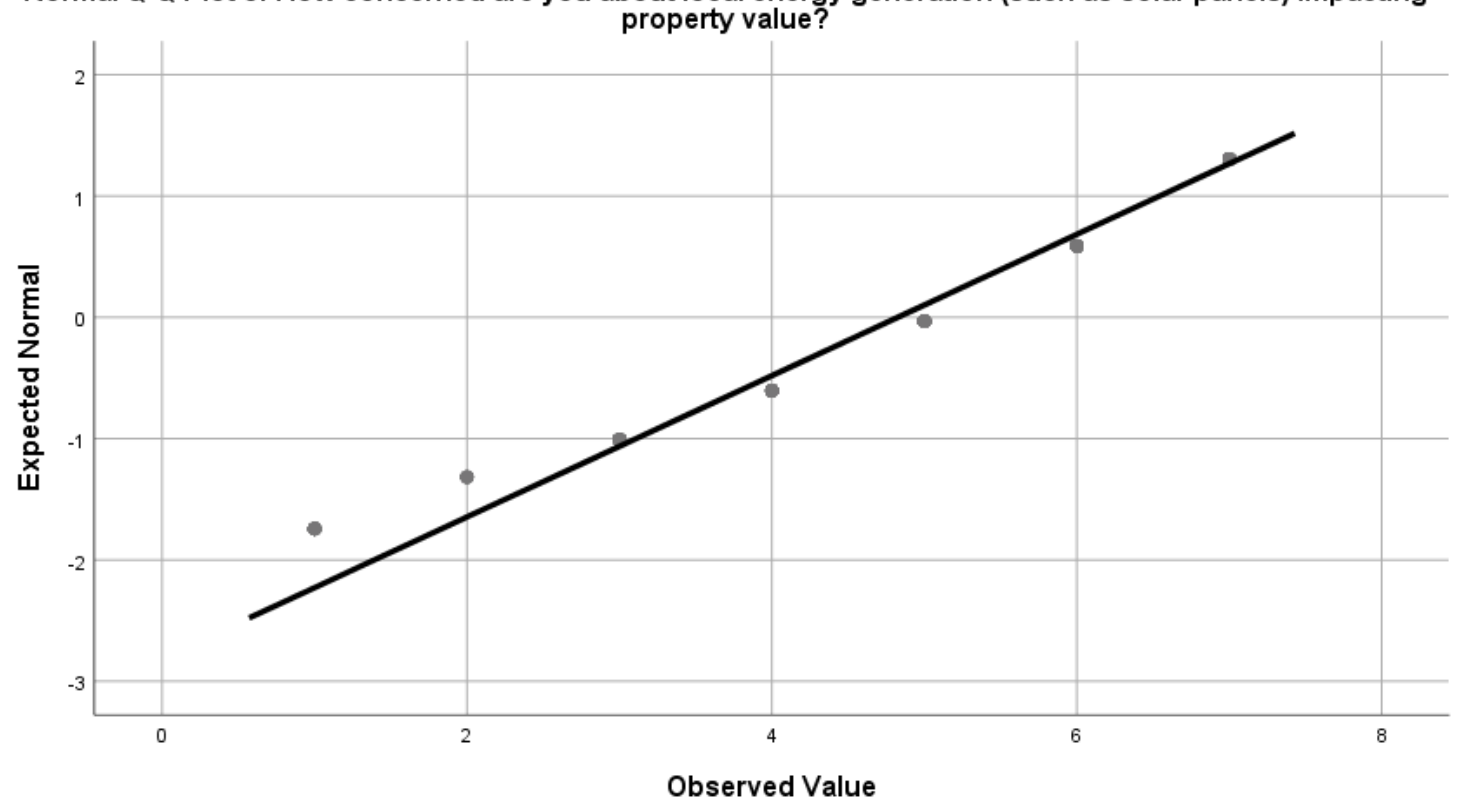


How likely are you to invest in local generation (such as through solar panels) to reduce outages or have power during/after an extreme weather event?

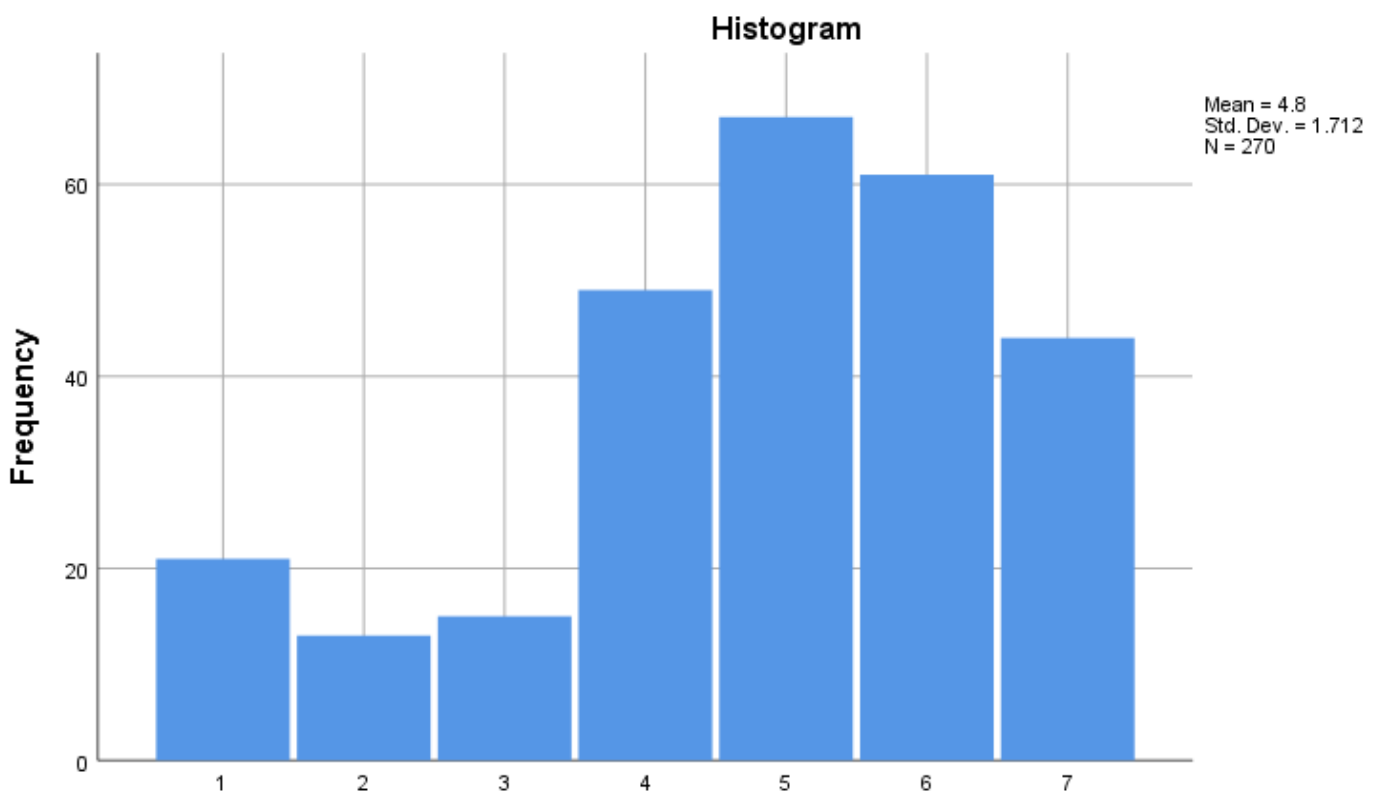

How likely are you to invest in local generation (such as through solar panels) to reduce outages or have power duringlafter an extreme weather event?

Normal Q-Q Plot of How likely are you to invest in local generation (such as through solar panels) to reduce outages or have power duringlafter an extreme weather event?

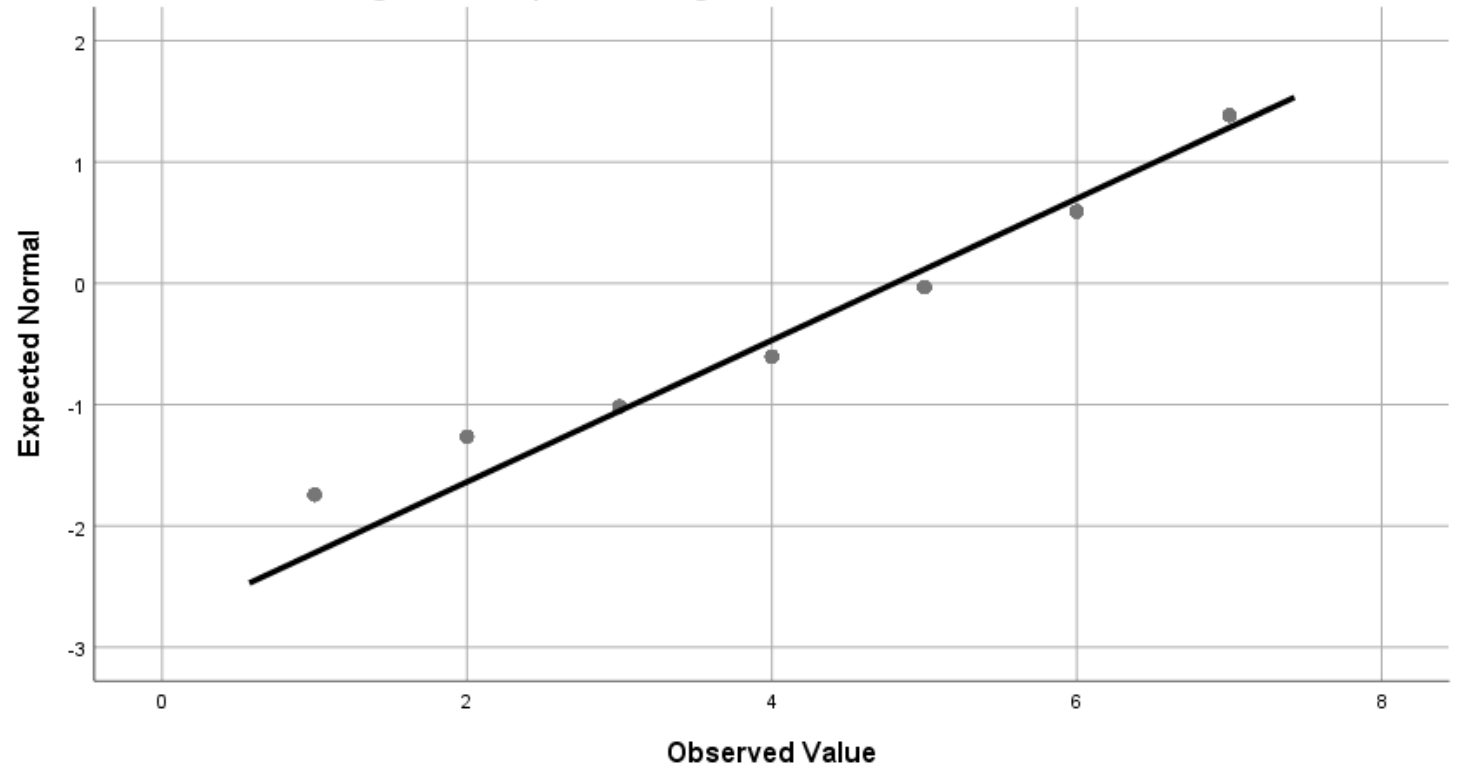


How likely are you to trust and adopt new energy generation technologies?

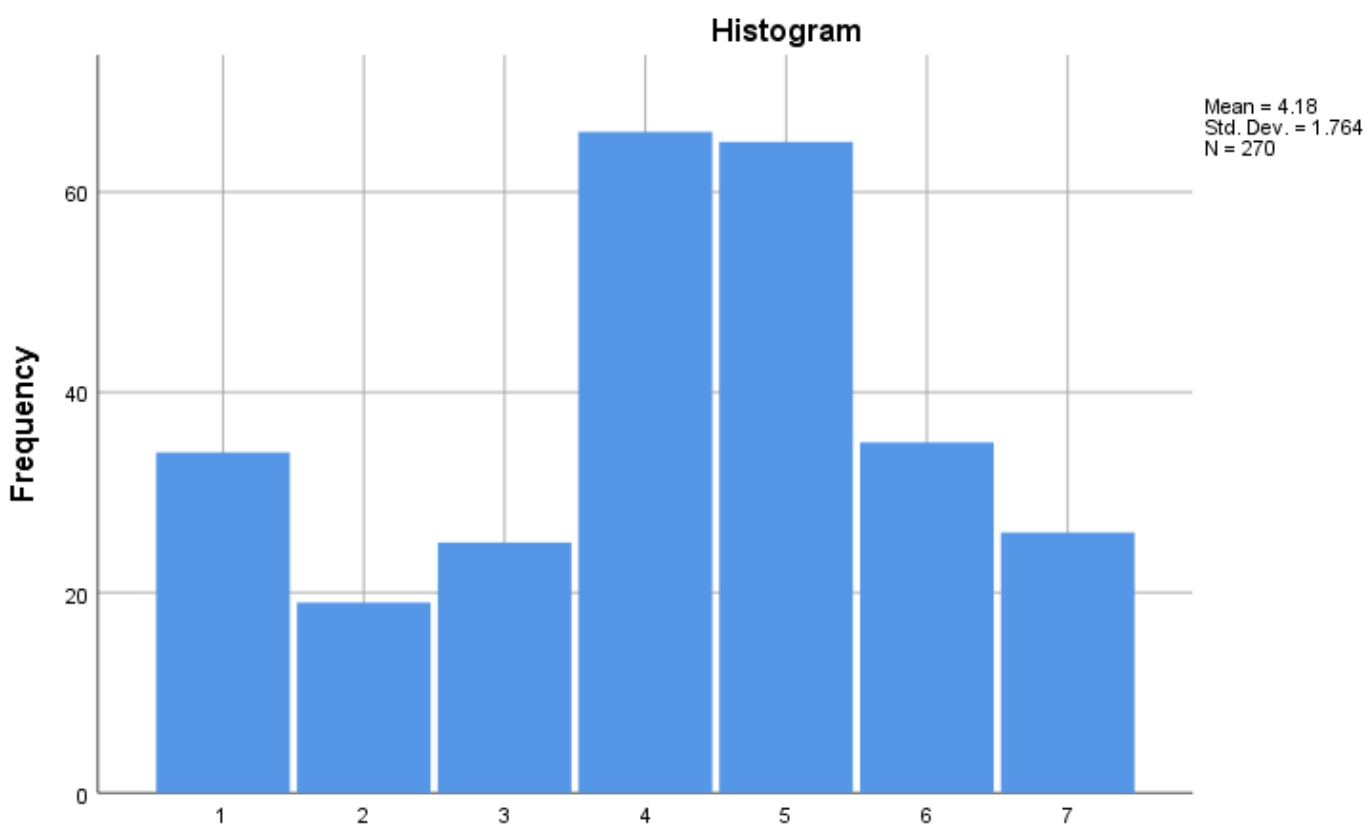

How likely are you to trust and adopt new energy generation technologies?

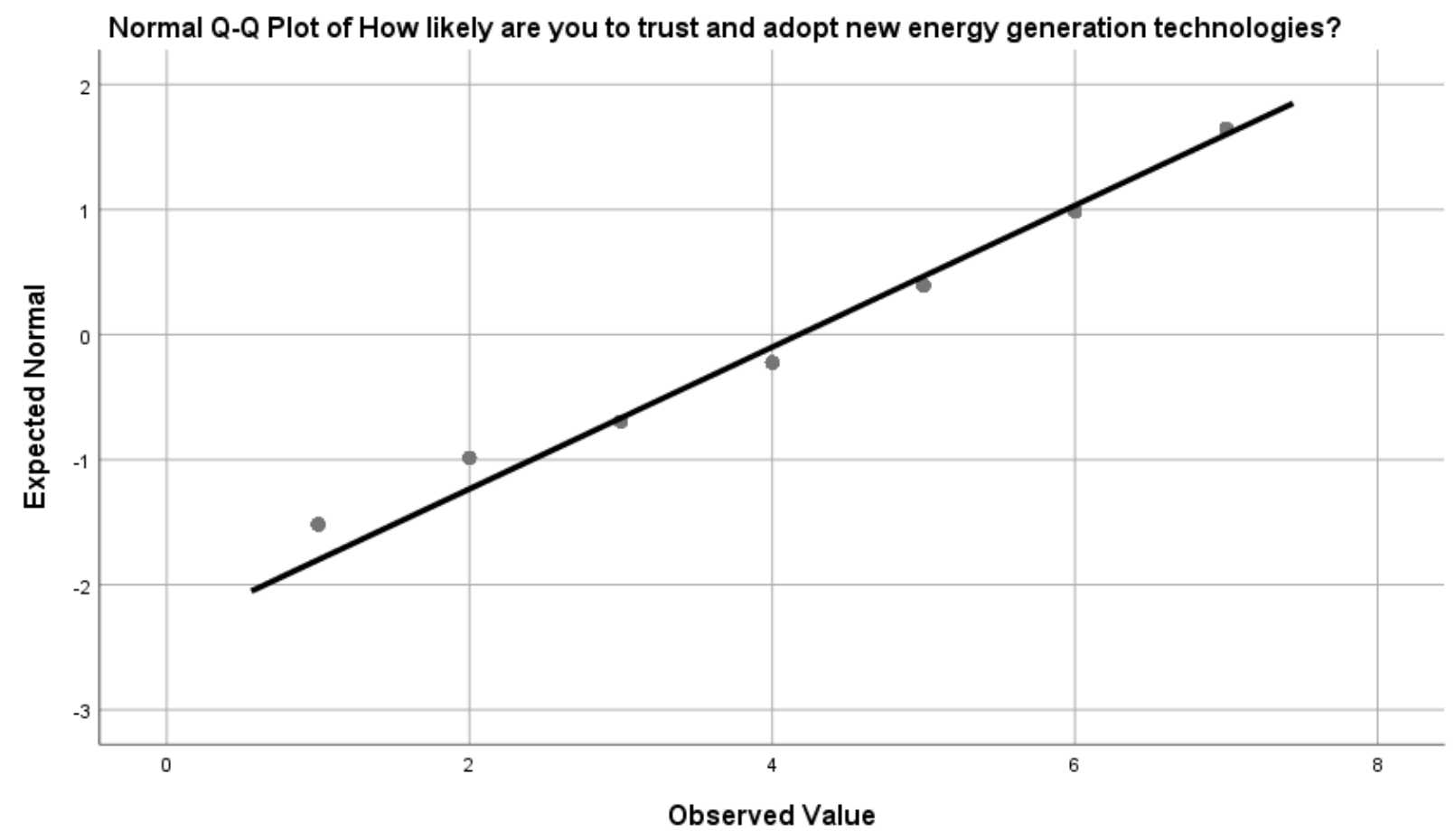


How likely are you to adopt renewable energy technologies such as solar panel in the next 5 years?

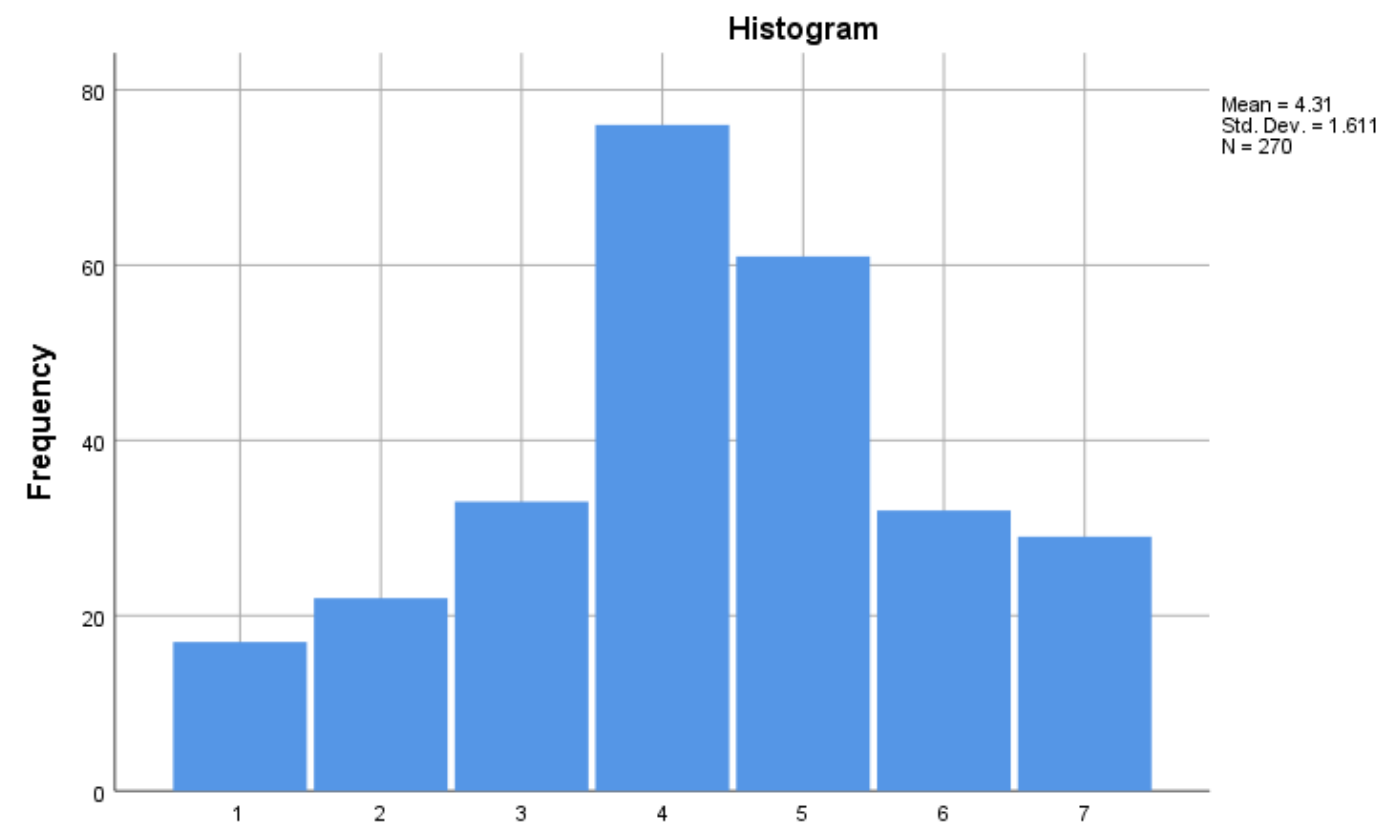

How likely are you to adopt renewable energy technologies such as solar panel in the next 5 years?

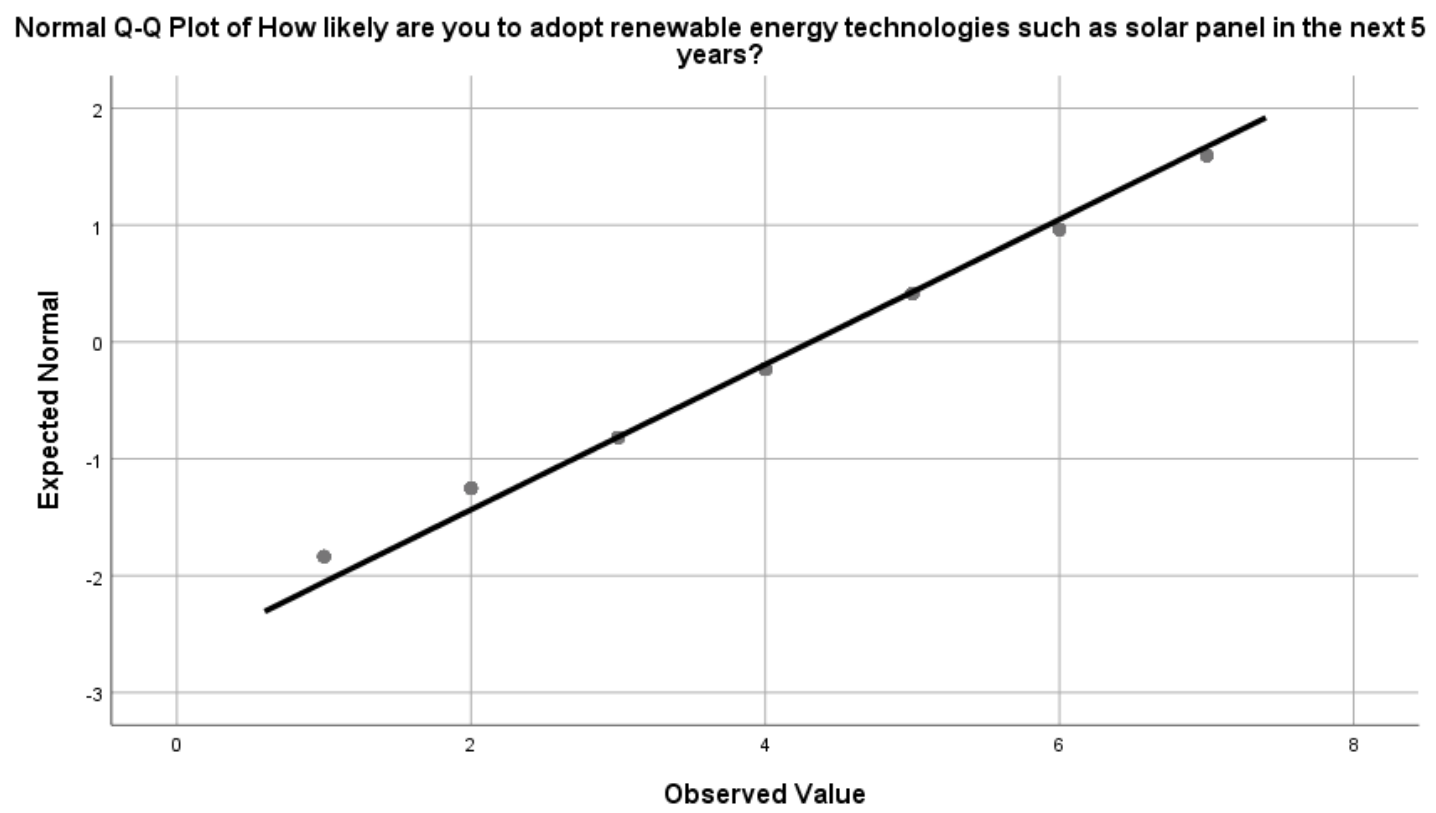


How many of your neighbours friends and acquaintances have installed a local energy generation system? (Please rate on a scale of 1- No one to 7 all of them)

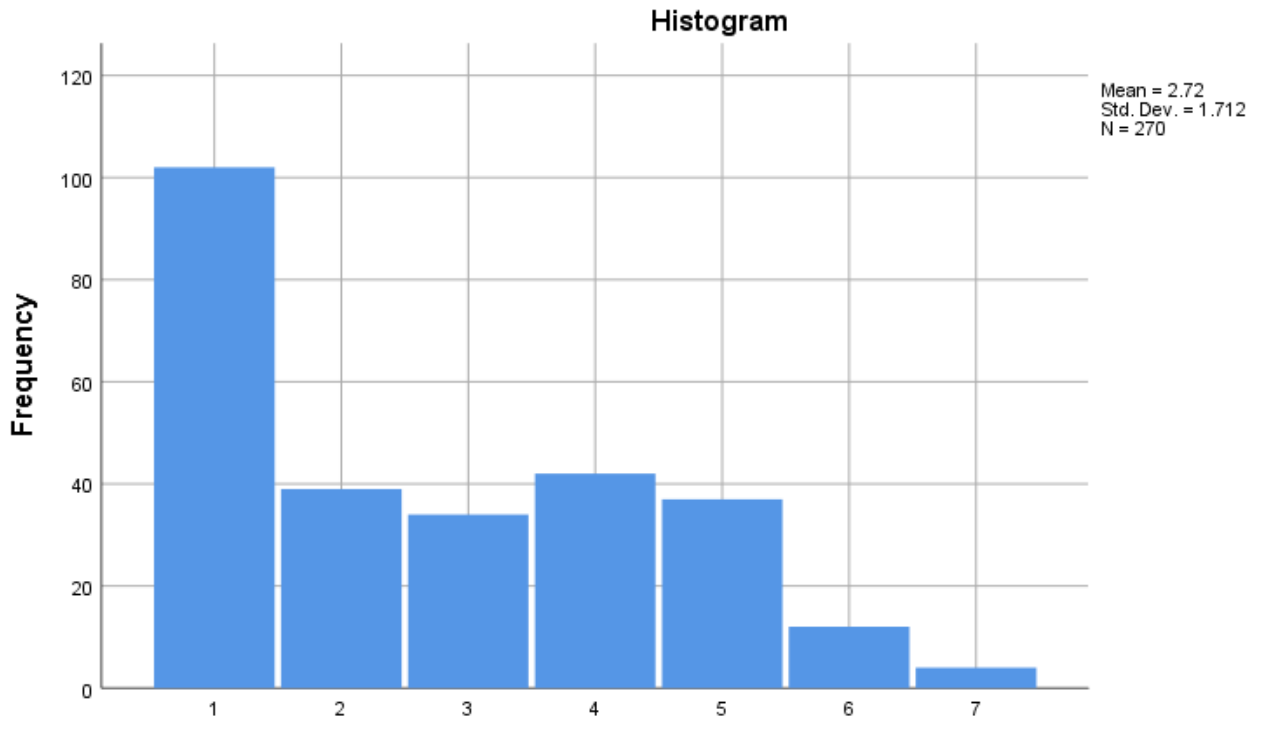

How many of your neighbors friends and acquaintances have installed a local energy generation system? (please rate on a scale of 1 - No one to 7 - all of them)

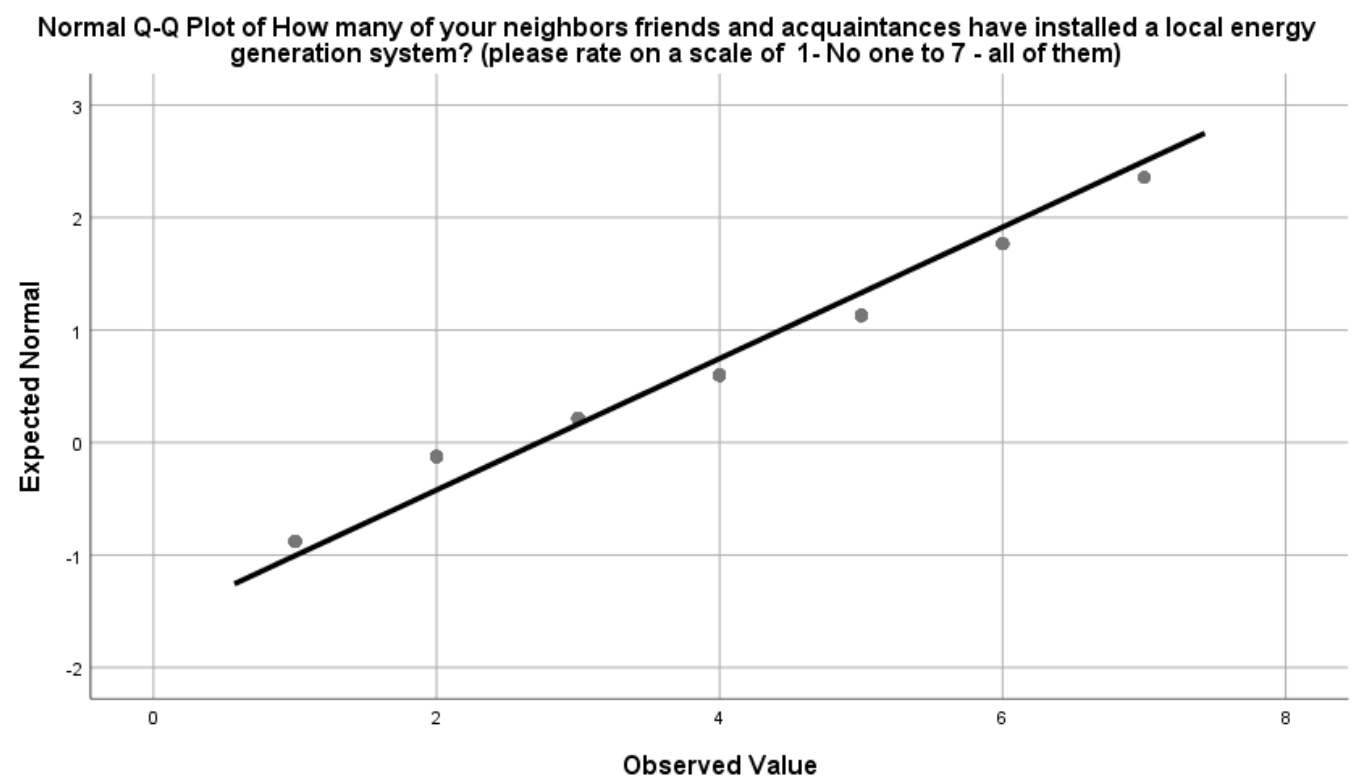




\section{I believe that most of my friends and acquaintances expect that $i$ will adopt}

renewable energy technologies (e.g. solar panels) within the next 5 years (please rate on a scale of 1 - strongly disagree to 7 - strongly agree)

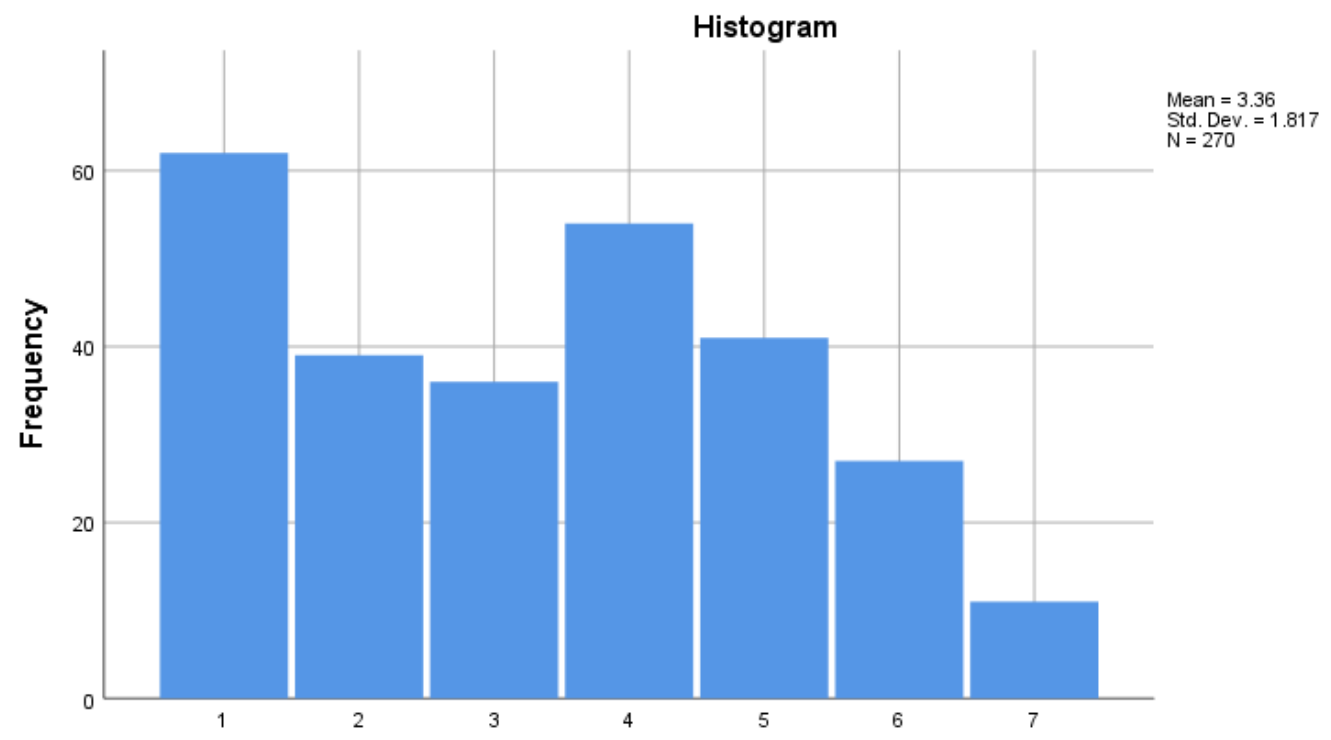

I believe that most of my friends and acquaintances expect that $i$ will adopt renewable energy technologies (e.g. solar panels) within the next 5 years (please rate on a scale of 1 - strongly disagree to 7 - strongly agree)

Normal Q-Q Plot of I believe that most of my friends and acquaintances expect that $i$ will adopt renewable energy technologies (e.g. solar panels) within the next 5 years (please rate on a scale of 1 - strongly disagree to

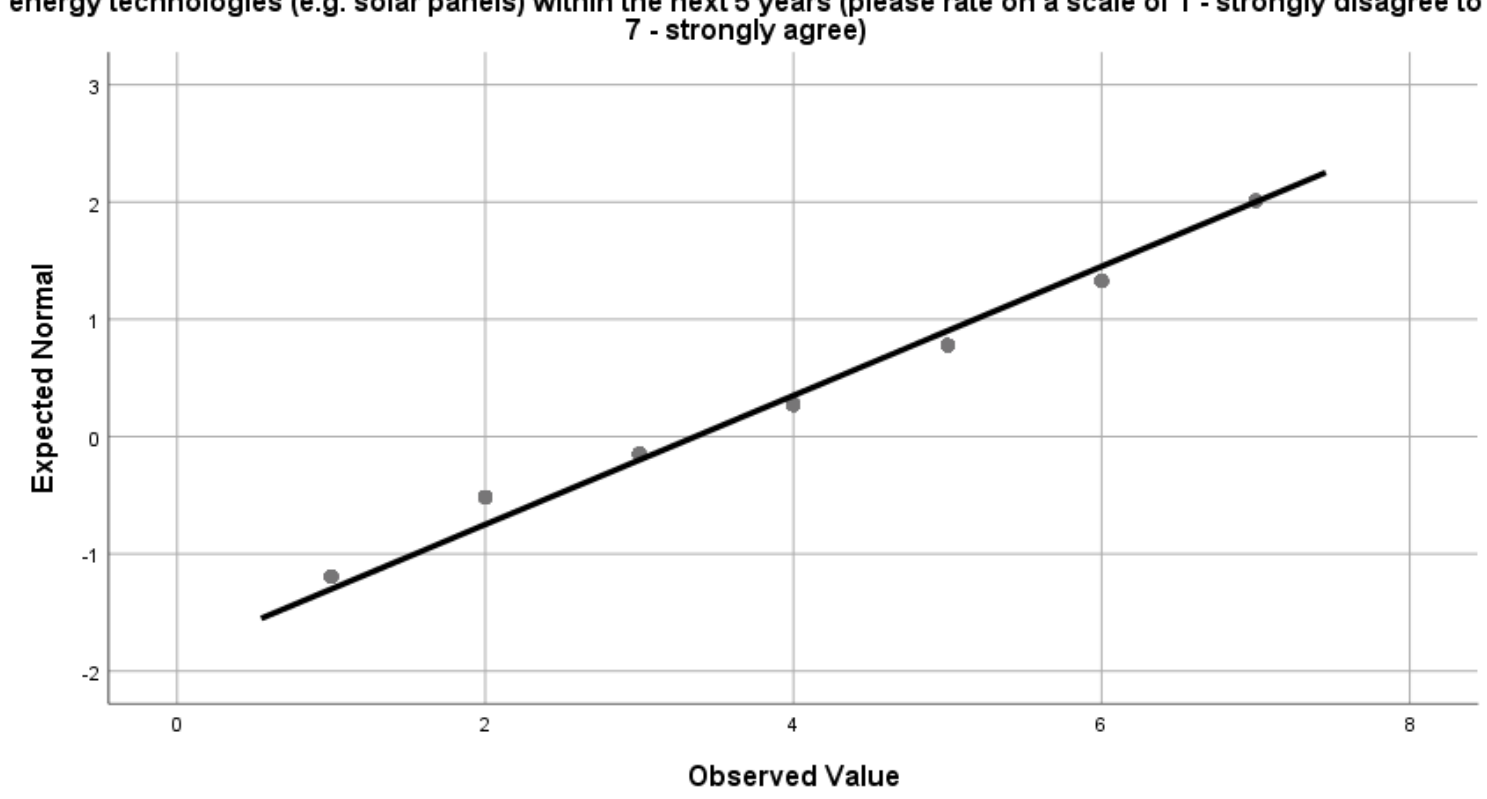




\section{Appendix B: Semi-structured Interviews Highlights}

\section{Stakeholders interviewed $(n=10)$}

Government (Provincial and Municipal): 2

Electricity system operator: 1

Energy sector think-tank: 2

Energy Entrepreneurs: 3

Practitioners (those who are part of an urban community energy project or have tried to create one): 2

Anonymous Semi-structured Interview Comments (Consistent themes have been highlighted below):

1. What is your definition and understanding of the phrase community energy? Can it manifest in the urban centers of the world? Why? Why not?

- Community energy needs to have a focus on community benefits including local jobs, building local community assets and sharing prosperity more widely.

- Community energy has been defined by different actors differently.

- Some developers used the term "community energy" rather broadly.

- For an energy project to be considered community energy, there has to be a local, place based constraint on the siting of the project.

- Urban community energy is increasingly possible with innovative micro-generation technologies being used.

- The main focus should be on creating new business models that involve and enrich the local residents as well as create clean energy.

- It's trying to identify or design new metrics that capture the benefits of community energy for urban environments.

- The power sector is only concerned with how much fuel to put into a power plant and how much electricity is being generated.

- Measures for benefits beyond cost per KWh are required.

- Solar is almost at grid parity in Ontario

- All new build should try to incorporate local generation, especially solar photovoltaic as much as possible. 
- Toronto is seeing so much development; new buildings are going up everywhere increasing energy consumption drastically.

- Local generation is required to meet this increase in need.

- Community energy could provide local generation options to provide extra load.

- Finding the right information and partners is a major challenge and without them it ultimately can lead to the failure of a proposed project regardless of community member interest in investing their time and money.

- There exist no clear paths or support networks to research community energy project properly.

- Urban centers have challenges especially regarding siting of energy projects as lack of space can cause challenges that have not really been felt in rural projects and it can be a significant barrier to urban community energy.

2. Which of these are most likely to happen in Toronto (urban centers in Ontario)? Why/why not?

a. Owned by some other entity (developer or municipality) with citizen participation in the form of investors

b. Community organization in partnership with a private party, owned and managed

c. Community organization owned and managed urban energy project

- People are not completely aware about the energy challenges for this planet.

- Some community members are willing to collaborate but many of them are not.

- Low levels of participation will be likely in urban centers such as Toronto.

- Many of the community participation models are based on assumptions of how people will collaborate with that kind of platform.

- It is being assumed that people will be willing to provide some flexibility to the grid by allowing operators of the grid to shut down some generation devices or storage when the energy is not needed. This remains an uncertainty.

- Toronto residents have experience participating in conservation demand management programs and partnering with the utility for energy related projects.

- Partnering with a $3^{\text {rd }}$ party organisation or the utility will not be too difficult to imagine, for Toronto residents, for local energy project participation.

- The first two options are likely to be more attractive to urban residents who will not often have the time to be involved in a community energy project, but might support it in concept and also perhaps motivated to be green.

\section{What is your feedback on the proposed questionnaire?}

- The questionnaire should not be too long or confusing, or else people will not complete them.

- The questionnaire needs to better explain the concepts associated with community energy. Perhaps more description within the question will help.

- Adding a question that asks respondents to rate the various motivations would be useful, to determine if all the factors are present, and which ones dominate.

- Financial factor will be considered most important by the respondents. 
- The three community energy models as explained in the questionnaire are confusing and open to interpretation. Providing more clarity to what low, medium and high levels of participation mean, would be useful.

- While selling electricity might be lucrative, it will be interesting to see how many people will buy electricity from a local project, or more importantly, buy locally generated electricity if it is more expensive than LDC provided supply.

- 'Participate' is an ambiguous term, what does it mean? It needs better definition. Is consultation considered participation?

- What would a joint venture look like? I think you need more definition here to expand on what exactly the relationship between the community member and the $3^{\text {rd }}$ party will look like in a jointly developed project. 
Appendix C: Questionnaire

\section{Investigating motivations and preferences for urban community energy}

Tell us more about yourself

1. Age group

Under 18 years of age

18 to 35

36 to 64

65 and above

2. Gender

Female

Male

Other

Choose not to disclose

3. I live in a

Condominium

Apartment

House

Housing Cooperative 
4. How frequently do you experience blackouts?

Less than twice a year

Between two and 6 a year

More than 6 a year

5. I care about the environment. (please rate on a scale of 1 - strongly disagree to 7 - strongly agree)

$\begin{array}{lllllll} & 2 & 4 & 5 & 6 & 7\end{array}$

6. I have a good understanding of the concept of local community energy (please rate on a scale of 1 - strongly disagree to 7 - strongly agree)

$\begin{array}{llllll}1 & 3 & 4 & 5 & 6 & 7\end{array}$

7. I feel strongly attached to the community I live in and I participate in community activities. (please rate on a scale of 1 - strongly disagree to 7 - strongly agree)

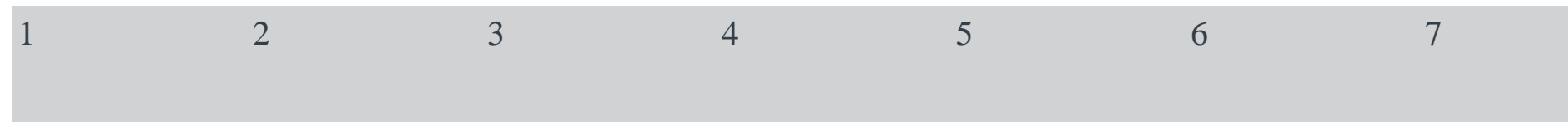


8. I would like to see renewable energy produced for local use in my community (please rate on a scale of 1 - strongly disagree to 7 - strongly agree)
1
2
3
4
5
6
7

For questions 9-24, please rate your answer on a scale of 1 to 7 where 1 corresponds to least and

7 to most (unless otherwise indicated in the text of the question).

9. How likely are you to lead and organise a local community energy project?

$\begin{array}{lllllll}1 & 2 & 3 & 4 & 5 & 6 & 7\end{array}$

10. How likely are you to contribute financially and invest money in a local community energy project?

$\begin{array}{lllll}1 & 2 & 4 & 5 & 6\end{array}$

$\begin{array}{llllll}1 & 2 & 3 & 4 & 5 & 6\end{array}$

12. How likely are you to participate in the planning of a local community energy project in a consultative capacity only?

$\begin{array}{lllllll}1 & 3 & 4 & 5 & 6 & 7\end{array}$


13. My ideal level of participation in a local community energy project is

High (attend majority of meetings, organize and encourage others to join, make decisions and take responsibility)

Medium (participate in some capacity but not be in lead)

Low (happy to support but do not have time to participate deeply)

Other (please specify)

14. How interested are you in owning a part of (such as few solar panels in a solar farm) a bigger local community energy project led by a developer?
1
2
3
4
5
6
7

15. How likely are you to produce energy and sell it to your neighbour?
12
3
4
5
6
16. How likely are you to buy energy from your neighbour/local community energy project?

7
1
2
3
4
5
6 
17. How likely are you to buy energy from a local community energy project or your neighbour even if it were more expensive than utility provided electricity?

$\begin{array}{lllllll}1 & 3 & 4 & 5 & 6 & 7\end{array}$

18. How likely are you to participate in a local community energy project if your neighbours/friends are participating?
1 2 3
4
5
6
19. How likely are you to invest in local energy generation (such as solar panels) if it increases

7 property value?

$\begin{array}{lllllll}2 & 3 & 4 & 5 & 6 & 7\end{array}$

20. How likely are you to invest in local generation (such as through solar panels) to reduce outages or have power during/after an extreme weather event?

$\begin{array}{lllllll}2 & 3 & 4 & 5 & 6 & 7\end{array}$

21. How likely are you to trust and adopt new energy generation technologies?

$\begin{array}{llllll}1 & 3 & 4 & 5 & 6 & 7\end{array}$


22. Please rate the following factors from 1 (highest) to 7 (lowest) for their ability to influence your decision about participating in local community energy projects

- Financial and cost

- Concern for the environment

- Security of supply (no outages because of bad weather) [ ]

- Impact on residence (increase/decrease in property value) [ ]

- Social network (what will friends and family think/do?) [ ]

- Trust in new technology

- Independence and freedom

23. How likely are you to adopt renewable energy technologies such as solar panel in the next 5 years?

$\begin{array}{lllllll}1 & 3 & 4 & 5 & 6 & 7\end{array}$

Other (please specify)

24. How many of your neighbours friends and acquaintances have installed a local energy generation system? (please rate on a scale of 1- No one to 7 - all of them)

$\begin{array}{lllll}1 & 2 & 3 & 4 & 5\end{array}$

6

25. I believe that most of my friends and acquaintances expect that I will adopt renewable energy technologies (e.g. solar panels) within the next 5 years (please rate on a scale of 1 - strongly disagree to 7 - strongly agree)

$\begin{array}{lllllll}1 & 3 & 4 & 5 & 6 & 7\end{array}$




\section{Appendix D: Regression Coefficients}

\section{Financial and security of supply:}

Community led and managed

\begin{tabular}{|c|c|c|c|c|c|c|c|c|}
\hline \multirow[b]{2}{*}{ Model } & & \multicolumn{2}{|c|}{$\begin{array}{l}\text { Unstandardized } \\
\text { Coefficients }\end{array}$} & \multirow{2}{*}{$\begin{array}{l}\text { Standardized } \\
\text { Coefficients } \\
\text { Beta }\end{array}$} & \multirow[b]{2}{*}{$\mathrm{t}$} & \multirow[b]{2}{*}{ Sig. } & \multicolumn{2}{|c|}{ Collinearity Statistics } \\
\hline & & $\mathrm{B}$ & $\begin{array}{l}\text { Std. } \\
\text { Error }\end{array}$ & & & & & VIF \\
\hline \multirow[t]{2}{*}{1} & (Constant) & 1.442 & 0.200 & & 7.228 & 0.000 & & \\
\hline & $\begin{array}{l}\text { How likely are you to produce } \\
\text { energy and sell it to your neighbour? }\end{array}$ & 0.605 & 0.046 & 0.620 & 13.123 & 0.000 & 1.000 & 1.000 \\
\hline \multirow[t]{3}{*}{2} & (Constant) & 0.967 & 0.198 & & 4.874 & 0.000 & & \\
\hline & $\begin{array}{l}\text { How likely are you to produce } \\
\text { energy and sell it to your neighbour? }\end{array}$ & 0.459 & 0.048 & 0.470 & 9.558 & 0.000 & 0.795 & 1.259 \\
\hline & $\begin{array}{l}\text { How likely are you to buy energy } \\
\text { from a local community energy } \\
\text { project or your neighbour even if it } \\
\text { were more expensive than utility } \\
\text { provided electricity? }\end{array}$ & 0.304 & 0.045 & 0.330 & 6.697 & 0.000 & 0.795 & 1.259 \\
\hline \multirow[t]{4}{*}{3} & (Constant) & 0.364 & 0.236 & & 1.541 & 0.124 & & \\
\hline & $\begin{array}{l}\text { How likely are you to produce } \\
\text { energy and sell it to your neighbour? }\end{array}$ & 0.332 & 0.055 & 0.341 & 6.078 & 0.000 & 0.575 & 1.740 \\
\hline & $\begin{array}{l}\text { How likely are you to buy energy } \\
\text { from a local community energy } \\
\text { project or your neighbour even if it } \\
\text { were more expensive than utility } \\
\text { provided electricity? }\end{array}$ & 0.263 & 0.045 & 0.285 & 5.863 & 0.000 & 0.761 & 1.314 \\
\hline & $\begin{array}{l}\text { How likely are you to invest in local } \\
\text { generation (such as through solar } \\
\text { panels) to reduce outages or have } \\
\text { power during/after an extreme } \\
\text { weather event? }\end{array}$ & 0.259 & 0.059 & 0.243 & 4.404 & 0.000 & 0.593 & 1.686 \\
\hline
\end{tabular}




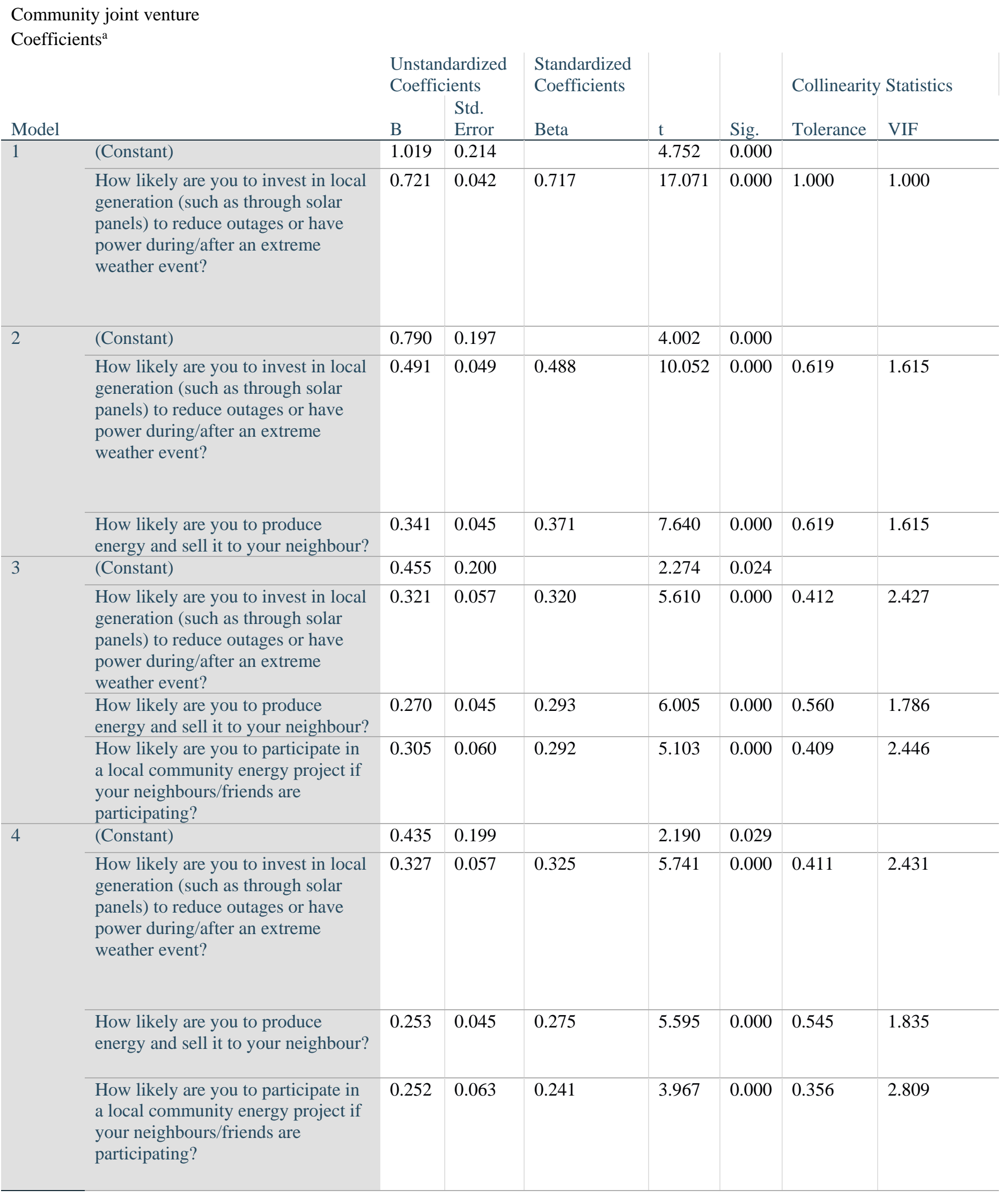


How likely are you to buy energy

$0.090 \quad 0.039$

0.103

2.314

\begin{tabular}{l|l}
0.021 & 0.663
\end{tabular}

1.509

from a local community energy project or your neighbour even if it were more expensive than utility provided electricity?

a. Dependent Variable: How interested are you in owning a part of (such as few solar panels in a solar farm) a bigger local community energy project led by a developer?

Community direct investment

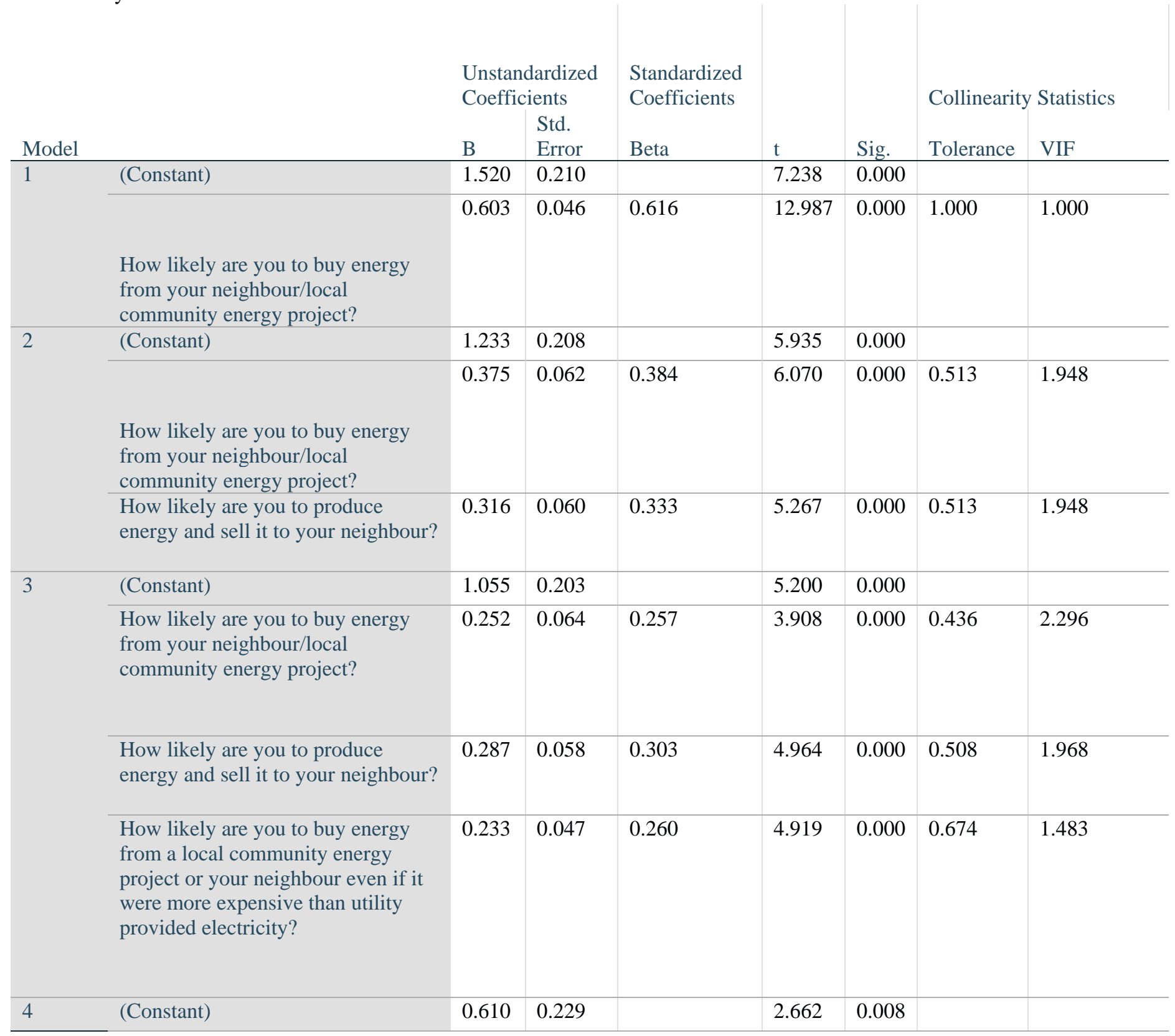




\begin{tabular}{|c|c|c|c|c|c|c|c|}
\hline $\begin{array}{l}\text { How likely are you to buy energy } \\
\text { from your neighbour/local } \\
\text { community energy project? }\end{array}$ & 0.133 & 0.070 & 0.136 & 1.901 & 0.058 & 0.351 & 2.847 \\
\hline $\begin{array}{l}\text { How likely are you to produce } \\
\text { energy and sell it to your neighbour? }\end{array}$ & 0.231 & 0.058 & 0.244 & 3.969 & 0.000 & 0.477 & 2.098 \\
\hline $\begin{array}{l}\text { How likely are you to buy energy } \\
\text { from a local community energy } \\
\text { project or your neighbour even if it } \\
\text { were more expensive than utility } \\
\text { provided electricity? }\end{array}$ & 0.229 & 0.046 & 0.255 & 4.943 & 0.000 & 0.674 & 1.484 \\
\hline $\begin{array}{l}\text { How likely are you to invest in local } \\
\text { generation (such as through solar } \\
\text { panels) to reduce outages or have } \\
\text { power during/after an extreme } \\
\text { weather event? }\end{array}$ & 0.245 & 0.064 & 0.237 & 3.858 & 0.000 & 0.478 & 2.090 \\
\hline
\end{tabular}

\section{Social norms:}

\section{Coefficients $^{\mathrm{a}}$}

\section{Community owned and managed}

\begin{tabular}{|c|c|c|c|c|c|c|c|c|}
\hline \multirow[b]{2}{*}{ Mod } & & \multicolumn{2}{|c|}{$\begin{array}{l}\text { Unstandardized } \\
\text { Coefficients }\end{array}$} & \multirow{2}{*}{$\begin{array}{l}\text { Standardized } \\
\text { Coefficients } \\
\text { Beta }\end{array}$} & \multirow[b]{2}{*}{$\mathrm{t}$} & \multirow[b]{2}{*}{ Sig. } & \multicolumn{2}{|c|}{ Collinearity Statistics } \\
\hline & & B & Error & & & & Tolerance & VIF \\
\hline \multirow[t]{2}{*}{1} & (Constant) & 2.341 & 0.181 & & 12.914 & 0.000 & & \\
\hline & $\begin{array}{l}\text { How many of your neighbours } \\
\text { friends and acquaintances have } \\
\text { installed a local energy generation } \\
\text { system? (please rate on a scale } \\
\text { of } 1 \text { - No one to } 7 \text { - all of them) }\end{array}$ & 0.541 & 0.057 & 0.494 & 9.474 & 0.000 & 1.000 & 1.000 \\
\hline \multirow[t]{2}{*}{2} & (Constant) & 1.869 & 0.203 & & 9.218 & 0.000 & & \\
\hline & $\begin{array}{l}\text { How many of your neighbours } \\
\text { friends and acquaintances have } \\
\text { installed a local energy generation } \\
\text { system? (please rate on a scale } \\
\text { of } 1-\text { No one to } 7 \text { - all of them) }\end{array}$ & 0.346 & 0.070 & 0.316 & 4.970 & 0.000 & 0.629 & 1.590 \\
\hline
\end{tabular}


I believe that most of my friends

0.299

\begin{tabular}{l|l}
0.065 & 0.293
\end{tabular}

4.614

\begin{tabular}{l|l}
$0.000 \quad 0.629$
\end{tabular}

1.590

and acquaintances expect that $\mathrm{i}$

will adopt renewable energy

technologies (e.g. solar panels)

within the next 5 years (please

rate on a scale of 1 - strongly

disagree to 7 - strongly agree)

a. Dependent Variable: How likely are you to lead and organise a local community energy project?

\section{Community joint venture}

\section{Coefficients $^{\mathrm{a}}$}

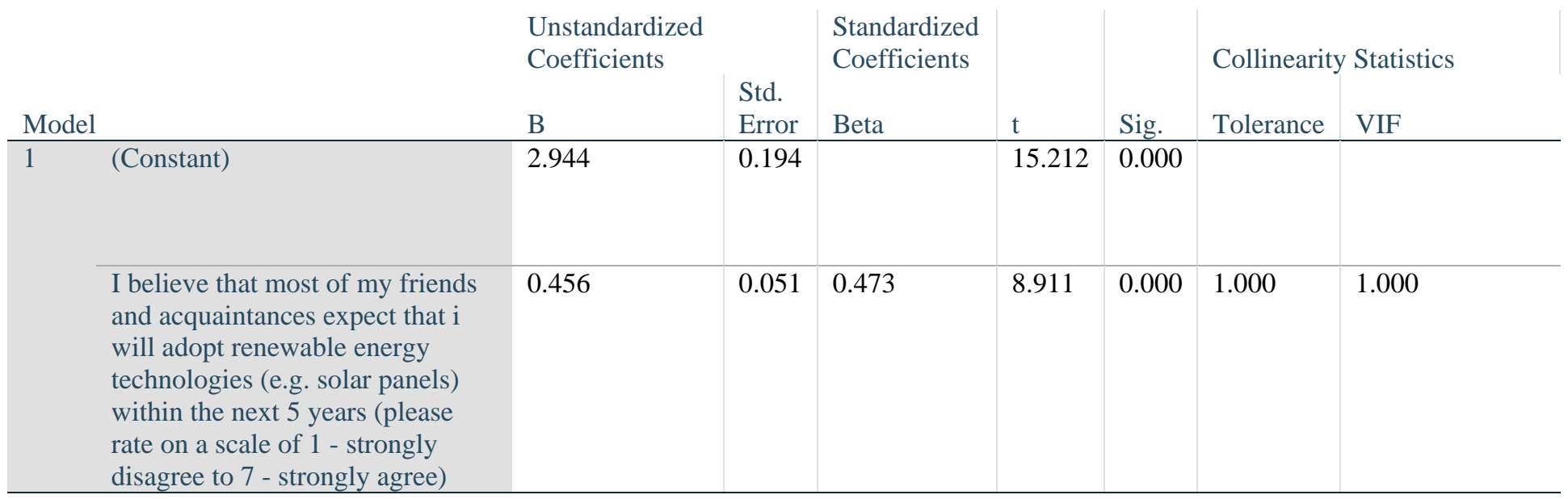

a. Dependent Variable: How interested are you in owning a part of (such as few solar panels in a solar farm) a bigger local community energy project led by a developer?

\section{Community direct investment}

Coefficients $^{\mathrm{a}}$

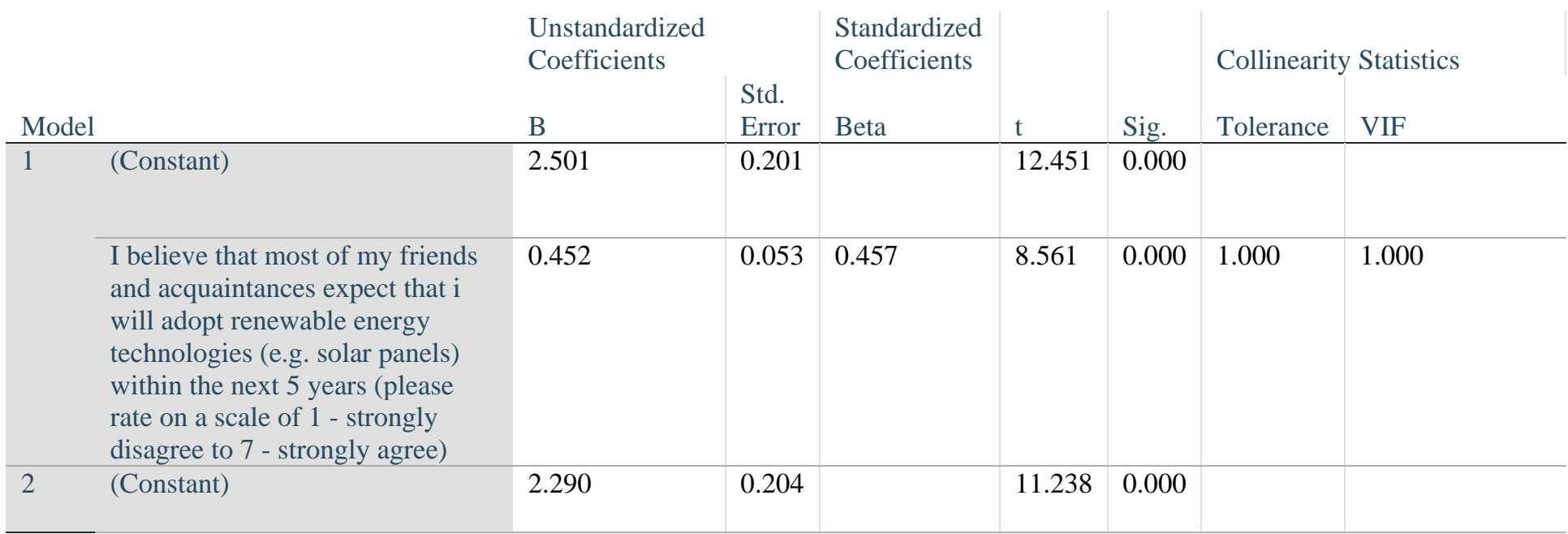


I believe that most of my friends and acquaintances expect that $\mathrm{i}$ will adopt renewable energy technologies (e.g. solar panels) within the next 5 years (please rate on a scale of 1 - strongly disagree to 7 - strongly agree)

How many of your neighbours

friends and acquaintances have installed a local energy generation system? (please rate on a scale of 1- No one to 7 - all of them)

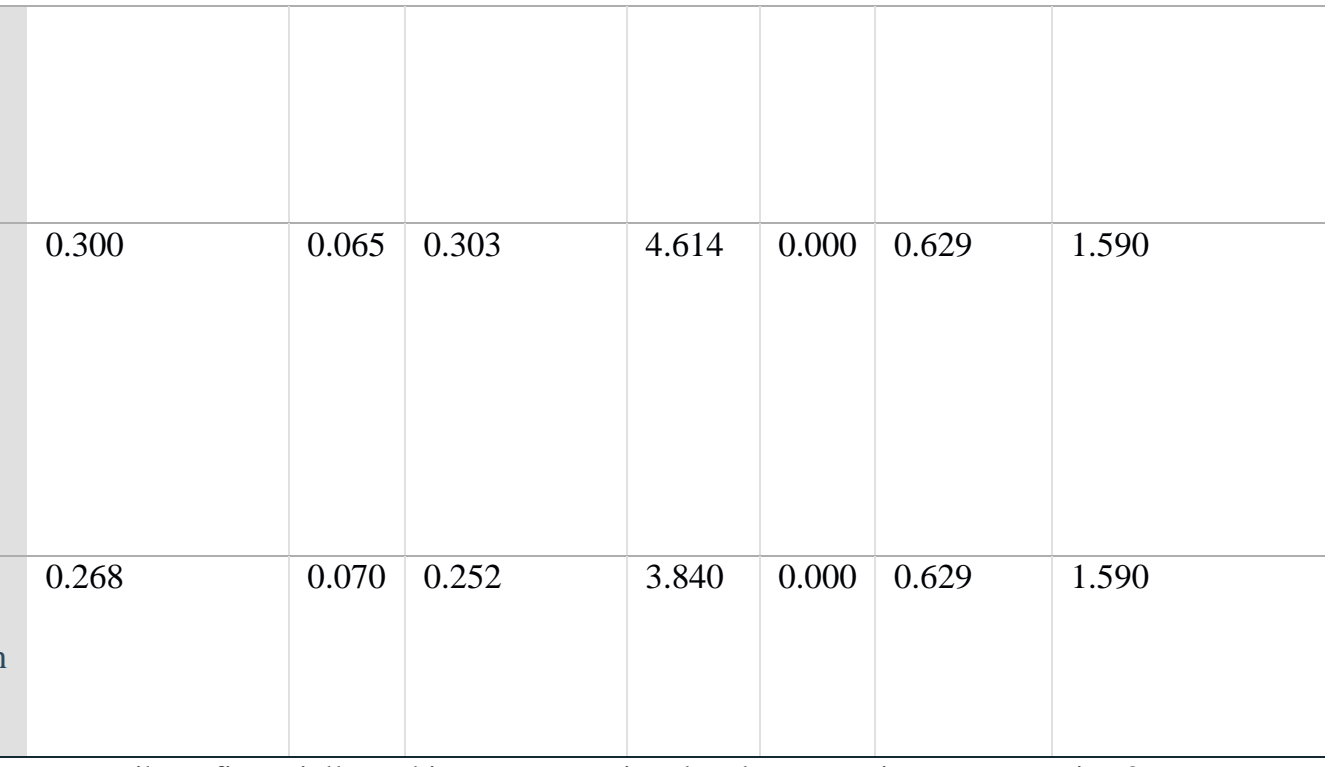

a. Dependent Variable: How likely are you to contribute financially and invest money in a local community energy project?

\section{Environmental awareness and community concern:}

\section{Community led and managed}

\begin{tabular}{|c|c|c|c|c|c|c|c|c|}
\hline \multirow[b]{2}{*}{ Model } & & \multicolumn{2}{|l|}{$\begin{array}{l}\text { Unstandardized } \\
\text { Coefficients }\end{array}$} & \multirow{2}{*}{$\begin{array}{l}\text { Standardize } \\
\mathrm{d} \\
\text { Coefficients } \\
\text { Beta }\end{array}$} & \multirow[b]{2}{*}{$\mathrm{t}$} & \multirow[b]{2}{*}{ Sig. } & \multicolumn{2}{|c|}{ Collinearity Statistics } \\
\hline & & B & Error & & & & nce & VIF \\
\hline 1 & (Constant) & 0.662 & $\begin{array}{l}0.33 \\
0\end{array}$ & & 2.005 & 0.046 & & \\
\hline & $\begin{array}{l}\text { I have a good understanding of } \\
\text { the concept of local community } \\
\text { energy (please rate on a scale } \\
\text { of } 1 \text { - strongly disagree to } 7 \text { - } \\
\text { strongly agree) }\end{array}$ & 0.663 & $\begin{array}{l}0.06 \\
7\end{array}$ & 0.511 & 9.904 & 0.000 & 1.000 & 1.000 \\
\hline 2 & (Constant) & -0.224 & $\begin{array}{l}0.36 \\
5\end{array}$ & & -0.613 & 0.541 & & \\
\hline & $\begin{array}{l}\text { I have a good understanding of } \\
\text { the concept of local community } \\
\text { energy (please rate on a scale } \\
\text { of } 1 \text { - strongly disagree to } 7 \text { - } \\
\text { strongly agree) }\end{array}$ & 0.479 & $\begin{array}{l}0.07 \\
4\end{array}$ & 0.370 & 6.444 & 0.000 & 0.747 & 1.338 \\
\hline
\end{tabular}




\begin{tabular}{|c|c|c|c|c|c|c|c|c|}
\hline & $\begin{array}{l}\text { I feel strongly attached to the } \\
\text { community I live in and I } \\
\text { participate in community } \\
\text { activities. (please rate on a } \\
\text { scale of } 1 \text { - strongly disagree } \\
\text { to } 7 \text { - strongly agree) }\end{array}$ & 0.359 & $\begin{array}{l}0.07 \\
3\end{array}$ & 0.282 & 4.913 & 0.000 & 0.747 & 1.338 \\
\hline \multirow[t]{4}{*}{3} & (Constant) & 0.624 & $\begin{array}{l}0.46 \\
2\end{array}$ & & 1.351 & 0.178 & & \\
\hline & $\begin{array}{l}\text { I have a good understanding of } \\
\text { the concept of local community } \\
\text { energy (please rate on a scale } \\
\text { of } 1 \text { - strongly disagree to } 7 \text { - } \\
\text { strongly agree) }\end{array}$ & 0.551 & $\begin{array}{l}0.07 \\
7\end{array}$ & 0.426 & 7.126 & 0.000 & 0.672 & 1.489 \\
\hline & $\begin{array}{l}\text { I feel strongly attached to the } \\
\text { community I live in and I } \\
\text { participate in community } \\
\text { activities. (please rate on a } \\
\text { scale of } 1 \text { - strongly disagree } \\
\text { to } 7 \text { - strongly agree) }\end{array}$ & 0.391 & $\begin{array}{l}0.07 \\
3\end{array}$ & 0.307 & 5.363 & 0.000 & 0.731 & 1.368 \\
\hline & $\begin{array}{l}\text { I care about the environment. } \\
\text { (please rate on a scale of } 1 \text { - } \\
\text { strongly disagree to } 7 \text { - } \\
\text { strongly agree) }\end{array}$ & -0.233 & $\begin{array}{l}0.08 \\
0\end{array}$ & -0.161 & -2.934 & 0.004 & 0.800 & 1.250 \\
\hline
\end{tabular}

\section{Joint Venture}

\begin{tabular}{|c|c|c|c|c|c|c|c|c|}
\hline Model & & \multicolumn{2}{|l|}{$\begin{array}{l}\text { Unstandardized } \\
\text { Coefficients }\end{array}$} & $\begin{array}{l}\text { Standardize } \\
\mathrm{d} \\
\text { Coefficients } \\
\text { Beta }\end{array}$ & $\mathrm{t}$ & \multirow{2}{*}{$\begin{array}{l}\text { Sig. } \\
0.000\end{array}$} & \multicolumn{2}{|c|}{ Collinearity Statistics } \\
\hline 1 & (Constant) & 2.156 & $\begin{array}{l}0.33 \\
3\end{array}$ & & 6.473 & & & \\
\hline & $\begin{array}{l}\text { I have a good understanding of } \\
\text { the concept of local community } \\
\text { energy (please rate on a scale } \\
\text { of } 1 \text { - strongly disagree to } 7 \text { - } \\
\text { strongly agree) }\end{array}$ & 0.487 & $\begin{array}{l}0.06 \\
7\end{array}$ & 0.398 & 7.217 & 0.000 & 1.000 & 1.000 \\
\hline
\end{tabular}

Community direct investment

Unstandardized

Coefficients

Model

1

(Constant)

B

1.626

\section{Standardize \\ d \\ Coefficients}

Std.

Error Beta t

\begin{tabular}{|l|l|l}
\hline 0.34 & 4.755 & 0.000
\end{tabular}

Zeroorder Partial 


\begin{tabular}{|c|c|c|c|c|c|c|c|c|}
\hline & $\begin{array}{l}\text { I have a good understanding of } \\
\text { the concept of local community } \\
\text { energy (please rate on a scale } \\
\text { of } 1 \text { - strongly disagree to } 7 \text { - } \\
\text { strongly agree) }\end{array}$ & 0.505 & $\begin{array}{l}0.06 \\
9\end{array}$ & 0.401 & 7.288 & 0.000 & 0.401 & 0.401 \\
\hline \multirow[t]{3}{*}{2} & (Constant) & 1.133 & $\begin{array}{l}0.38 \\
9\end{array}$ & & 2.909 & 0.004 & & \\
\hline & $\begin{array}{l}\text { I have a good understanding of } \\
\text { the concept of local community } \\
\text { energy (please rate on a scale } \\
\text { of } 1 \text { - strongly disagree to } 7 \text { - } \\
\text { strongly agree) }\end{array}$ & 0.403 & $\begin{array}{l}0.07 \\
9\end{array}$ & 0.320 & 5.076 & 0.000 & 0.401 & 0.292 \\
\hline & $\begin{array}{l}\text { I feel strongly attached to the } \\
\text { community I live in and I } \\
\text { participate in community } \\
\text { activities. (please rate on a } \\
\text { scale of } 1 \text { - strongly disagree } \\
\text { to } 7 \text { - strongly agree) }\end{array}$ & 0.200 & $\begin{array}{l}0.07 \\
8\end{array}$ & 0.162 & 2.562 & 0.011 & 0.322 & 0.152 \\
\hline
\end{tabular}

Trust in new technology:

\section{Community owned and managed}

\section{Coefficients $^{\mathrm{a}}$}

\begin{tabular}{|c|c|c|c|c|c|c|c|c|}
\hline \multirow[b]{2}{*}{ Model } & & \multicolumn{2}{|l|}{$\begin{array}{l}\text { Unstandardized } \\
\text { Coefficients }\end{array}$} & Standardized & \multirow[b]{2}{*}{$\mathrm{t}$} & \multirow[b]{2}{*}{ Sig. } & \multicolumn{2}{|c|}{ Collinearity Statistic } \\
\hline & & $\mathrm{B}$ & Error & Beta & & & Tolerance & VIF \\
\hline 1 & (Constant) & 3.080 & 0.282 & & 10.923 & 0.000 & & \\
\hline & $\begin{array}{l}\text { How likely are you to trust and } \\
\text { adopt new energy generation } \\
\text { technologies? }\end{array}$ & 0.171 & 0.062 & 0.163 & 2.748 & 0.006 & 1.000 & 1.000 \\
\hline
\end{tabular}

a. Dependent Variable: How likely are you to lead and organise a local community energy project?

\section{Joint venture}

\section{Coefficients $^{a}$}

\begin{tabular}{|c|c|c|c|c|c|c|c|}
\hline & $\begin{array}{l}\text { Unstandardized } \\
\text { Coefficients }\end{array}$ & & $\begin{array}{l}\text { Standardized } \\
\text { Coefficients }\end{array}$ & & & Collinearity & Statistics \\
\hline Model & B & Error & Beta & $\mathrm{t}$ & Sig. & Tolerance & VIF \\
\hline $1 \quad$ (Constant) & 2.990 & 0.252 & & 11.846 & 0.000 & & \\
\hline
\end{tabular}


How likely are you to trust and adopt new energy generation technologies?

a. Dependent Variable: How interested are you in owning a part of (such as few solar panels in a solar farm) a bigger local community energy project by a developer?

\section{Community direct investment Coefficients $^{\mathrm{a}}$}

Model

\begin{tabular}{ll} 
& \\
\hline $1 \quad$ & (Constant) \\
& \\
& How likely are you to trust and \\
& adopt new energy generation \\
& technologies?
\end{tabular}

\begin{tabular}{ll|l|l|l|l|l|}
$\begin{array}{l}\text { Unstandardized } \\
\text { Coefficients }\end{array}$ & & $\begin{array}{l}\text { Standardized } \\
\text { Coefficients }\end{array}$ & $\mathrm{t}$ & Sig. & Collinearity Statistics \\
\hline B & $\begin{array}{l}\text { Std. } \\
\text { Error }\end{array}$ & Beta & & & Tolerance & VIF \\
\hline 2.414 & 0.257 & & 9.385 & 0.000 & & \\
\hline 0.382 & 0.057 & 0.376 & 6.745 & 0.000 & 1.000 & 1.000 \\
\hline & & & & & & \\
\hline
\end{tabular}

a. Dependent Variable: How likely are you to contribute financially and invest money in a local community energy project? 


\section{References}

Ackerman, F. (1997). Consumed in theory: alternative perspectives on the economics of consumption. Journal of Economic Issues, 31(3), 651-664.

Ajzen, I. (1991). The theory of planned behavior. Organizational Behavior and Human Decision Processes 50, 179-211.

Allen, I. E., \& Seaman, C. A. (2007). Likert scales and data analyses. Quality progress, 40(7), 64-65.

Angel, J. (2016). Towards an Energy Politics In-Against-and-Beyond the State: Berlin's Struggle for Energy Democracy. Antipode.

Angen, M. J. (2000). Evaluating interpretive inquiry: Reviewing the validity debate and opening the dialogue. Qualitative health research, 10(3), 378-395.

Arnstein, S. (1969). "A ladder of citizen participation." Journal of the American Institute of

Planners, Vol. 35, No. 4, pg. 216.

Backhaus, J., Breukers, S., Paukovic, M., Mourik, R., \& Mont, O. (2012). Sustainable

Lifestyles. Today's Facts and Tomorrow's Trends. D1. 1 Sustainable lifestyles baseline report.

Balcombe, P., Rigby, D., \& Azapagic, A. (2013). Motivations and barriers associated with adopting microgeneration energy technologies in the UK. Renewable and Sustainable Energy Reviews, 22, 655-666.

Bamberg, S., Rees, J., \& Seebauer, S. (2015). Collective climate action: Determinants of participation intention in community-based pro-environmental initiatives. Journal of

Environmental Psychology, 43, 155-165. Doi:10.1016/j.jenvp.2015.06.006

Barnes, S. (2012). Building Community Leadership for a Healthier Toronto. Wellesley

Institute. Accessed at https://www.wellesleyinstitute.com/wp-

content/uploads/2012/11/Building-Community-Leadership-For-A-Healthier-Toronto1.pdf

Bauwens, T. (2016). Explaining the diversity of motivations behind community renewable energy. Energy Policy, 93, 278-290.

Bauwens, T., Gotchev, B., \& Holstenkamp, L. (2016). What drives the development of community energy in Europe? The case of wind power cooperatives. Energy Research \& Social Science, 13, 136-147.

Bechberger, M., \& Reiche, D. (2004). Renewable energy policy in Germany: pioneering and exemplary regulations. Energy for Sustainable Development,8(1), 47-57.

Bellekom, S., \& Arentsen, M. (2014). Power to the people: Local energy initiatives as seedbeds of innovation? Energy, Sustainability and Society, 4(1), 1-12. Doi:10.1186/21920567-4-2

Bergek, A., Mignon, I., \& Sundberg, G. (2013). Who invests in renewable electricity production? Empirical evidence and suggestions for further research. Energy Policy, 56, 568581.

Bijlsma, J., Eijndhoven, J.V., \& Turkenburg, W. (1988). Experiences with Public Participation in Decision-making Concerning Energy Policy in the Netherlands. Bulletin of Science,

Technology \& Society, Vol. 8, No. 4, pp. 397-404.

Blanchet, T. (2015). Struggle over energy transition in Berlin: How do grassroots initiatives affect local energy policy-making?. Energy Policy, 78, 246-254.

Bolinger, M. (2001). Community wind power ownership schemes in Europe and their relevance to the United States. Lawrence Berkeley National Laboratory. 
Botsman, R. \& Rogers, R. (2010). Beyond Zipcar: Collaborative Consumption. Harward Business Review.

Botsman, R. "The sharing economy lacks a shared definition." Fast Company 21 (2013): 2013. Boyatzis, R. E. (1998). Transforming qualitative information: Thematic analysis and code development. Sage.

Breukers, S., \& Wolsink, M. (2007). Wind power implementation in changing institutional landscapes: An international comparison. Energy Policy, 35(5), 2737-2750.

Britten, N. (2007). Qualitative interviews. Qualitative Research in Health Care, Third Edition, 12-20.

Brooklyn Microgrid. (2017). Brooklyn Microgrid. Accessed at http://brooklynmicrogrid.com/

Caird, S., \& Roy, R. (2010). Adoption and use of household microgeneration heat technologies. Low Carbon Economy, 1(2), 61-70.

Campbell, R. J. (2012). Weather-related power outages and electric system resiliency.

Washington, DC: Congressional Research Service, Library of Congress.

Canadian Co-op Association (CCA, 2011). Renewable energy co-ops in Canada.

Cardwell, D. (2017). Solar Experiment Lets Neighbours Trade Energy Among Themselves.

The New York Times. Accessed at https://www.nytimes.com/2017/03/13/business/energy-

environment/brooklyn-solar-grid-energy-trading.html?_r=0

Cassell, C., \& Symon, G. (Eds.). (2004). Essential guide to qualitative methods in

organizational research. Sage.

Cialdini, R.B., 1983. Influence. The Psychology of Persuasion. HarperCollins.

City of Edmonton. (2015). Open city open engagement: Council Initiative on Public Engagement.

Accessed at

https://www.edmonton.ca/city government/documents/PDF/CouncillnitiativeonPublicEngagementP

hase1FinalReport.pdf

Coleman, S., \& Gotze, J. (2001). Bowling together: Online public engagement in policy

deliberation (pp. 39-50). London: Hansard Society.

Corscadden, K., Wile, A., \& Yiridoe, E. (2012). "Social license and consultation criteria for

community wind projects.” Renewable Energy, Vol. 44, pp. 392-397.

Cossent, R., Gómez, T., \& Frías, P. (2009). Towards a future with large penetration of

distributed generation: Is the current regulation of electricity distribution ready? Regulatory

recommendations under a European perspective. Energy Policy, 37(3), 1145-1155.

Couper, M. P. (2008). Designing effective web surveys (Vol. 75). New York: Cambridge

University Press.

Creswell, J. W. (2003). Research design.

Creswell, J. W., Plano Clark, V. J., \& Hanson, W. E. (2003). A handbook of mixed methods in social and behavioural research. Advanced mixed methods research designs, 209-240.

Curtius, H. C., Hille, S. L., Berger, C., Hahnel, U. J. J., \& Wüstenhagen, R. (2018). Shotgun or snowball approach? Accelerating the diffusion of rooftop solar photovoltaics through peer effects and social norms. Energy Policy, 118, 596-602.

Delanty, G., \& Strydom, P. (2003). Philosophies of social science: The classic and contemporary readings.

Delre, S.A., Jager, W. \& Janssen, M.A. (2004). Percolation and innovation diffusion models compared: do network structures and social preferences matter? Paper presented at the M2M2 workshop of the ESSA2 conference, Valladolid, Spain, September 2004. 
Devine-Wright, P. (2005). Beyond NIMBYism: towards an integrated framework for understanding public perceptions of wind energy. Wind energy, 8(2), 125-139.

Dietz, R., \& O’Neill, D. W. (2013). Enough is enough: Building a sustainable economy in a world of finite resources. Routledge.

Dóci, G., \& Vasileiadou, E. (2015). "Let' s do it ourselves" Individual motivations for investing in renewables at community level. Renewable and Sustainable Energy Reviews, 49, 41-50.

Driscoll, D. L., Appiah-Yeboah, A., Salib, P., \& Rupert, D. J. (2007). Merging qualitative and quantitative data in mixed methods research: How to and why not. Ecological and Environmental Anthropology (University of Georgia), 18.

Ecopower (2013).Power Post-Nieuwsbrief van Ecopower cvba. Ecopower cvba, Berchem. Farrell, J. (2016). Beyond Sharing: How Communities Can Take Ownership of Renewable Power. ISLR

Frey, B. S. (1997). Not just for the money. A theory of personal motivation. Cheltenham : Edward Elgar.

German Cooperative and Raiffeisen Confederation. (2015). Energy Cooperatives: Results of the DGRVSurvey.Accessed at

https://www.dgrv.de/weben.nsf/272e312c8017e736c1256e31005cedff/e7b7b885ccf6c6e8c1257e8 4004f9047/\$FILE/Survey Energy Cooperations 2014.pdf.

German Federal Ministry for Economic Affairs and Energy. (2015). Factsheet: Renewables from

Germany. Accessed at http://www.energiewende2015.com/wpcontent/uploads/2015/03/Factsheet-Renewables-from-Germany.pdf.

Gipe, P. (1996) Community-owned Wind Development in Germany, Denmark and the Netherlands

Gipe, P. (2009). Wind Energy Basics: A Guide to Home and Community-Scale Wind-Energy Systems. Chelsea Green Publishing

Goossens, Y., \& Mäkipää, A. (2007). Alternative progress indicators to Gross Domestic Product (GDP) as a means towards sustainable development. Beyond GDP, 305.

Groves, R. M., Fowler Jr, F. J., Couper, M. P., Lepkowski, J. M., Singer, E., \& Tourangeau, R. (2013). Survey methodology. John Wiley \& Sons.

Guba, E. G. (Ed.). (1990). The paradigm dialog. Sage Publications.

Haggett, C. (2011). "Understanding public responses to offshore wind power." Energy Policy, Vol. 39, No. 2, pp. 503-510.

Haggett, C., Creamer, E., Harnmeijer, J., Parsons, M., \& Bomberg, E. (2013). Community energy in Scotland: the social factors for success. Edinburgh: University of Edinburgh.

Haucap, J. (2007). The costs and benefits of ownership unbundling. Intereconomics, 42(6), 301-304.

Hausbeck, K. W., Milbrath, L. W., \& Enright, S. M. (1992). Environmental knowledge, awareness and concern among 11th-grade students: New York State. The Journal of Environmental Education, 24(1), 27-34.

Hausman, A, (2000). A multi-method investigation of consumer motivations in impulse buying behavior. Journal of Consumer Marketing, 17, 403-419.

Heinrichs, H. (2013). Sharing economy: a potential new pathway to sustainability. Gaia, 22(4), 228.

Helby, P. (1998). Renewable energy projects in Sweden: An overview of subsidies, taxation, ownership and finance. Department of Environemntal and Energy System Studies. 
Hier opgewekt. (2016). Local energy monitor 2015. Accessed

at http://www.hieropgewekt.nl/sites/default/files/u20232/lokale energie monitor 2015 uitgave januari 2016.pdf.

Hoffman, S. M., \& High-Pippert, A. (2005). Community energy: a social architecture for an alternative energy future. Bulletin of Science, Technology \& Society, 25(5), 387-401. Hoffman, S. M., \& High-Pippert, A. (2010). From private lives to collective action: Recruitment and participation incentives for a community energy program. Energy Policy, 38(12), 7567-7574.

Hoffman, S. M., Fudge, S., Pawlisch, L., High-Pippert, A., Peters, M., \& Haskard, J. (2013). Public values and community energy: Lessons from the US and UK. Sustainability, 5(4), 1747-1763.

Hoicka, C. (2012). Understanding Pro-Environmental Behaviour as Process: Assessing the Importance of Program Structure and Advice-Giving in a Residential Home Energy Evaluation Program.

Holburn, G., Lui, K., \& Morand, C. (2010). Policy Risk and Private Investment in Ontario's Wind Power Sector. Canadian Public Policy, 36(4), 465-486.

Holstenkamp, L., \& Kahla, F. (2016). What are community energy companies trying to accomplish? An empirical investigation of investment motives in the German case. Energy Policy, 97, 112-122.

Huybrechts, B., \& Mertens, S. (2014). The relevance of the cooperative model in the field of renewable energy: The relevance of the cooperative model. Annals of Public and Cooperative Economics, 85(2), 193-212.

IEA. (2017). International Energy Statistics. Accessed at https://www.eia.gov/beta/international/data/browser/\#/?pa $=00000000000000000000000000000 \mathrm{fvu}$ \&c=00000000000g\&ct=0\&t| id=2-A\&vs=INTL.2-12-DEU-BKWH.A\&vo=0\&v=H\&start=1980\&end=2014 International Energy Agency. (2016). Energy Technology Perspectives.

Jackson, T., \& Senker, P. (2011). Prosperity without growth: Economics for a finite planet. Energy \& Environment, 22(7), 1013-1016.

Jager, W. (2006). Stimulating the diffusion of photovoltaic systems: A behavioural perspective. Energy Policy, 34(14), 1935-1943.

Jami, A. A., \& Walsh, P. R. (2014). The role of public participation in identifying stakeholder synergies in wind power project development: The case study of Ontario, Canada. Renewable Energy, 68, 194-202.

Jobert, A., Laborgne, P., \& Mimler, S. (2007). Local acceptance of wind energy: Factors of success identified in French and German case studies. Energy policy, 35(5), 2751-2760.

Johnson, R. B., \& Onwuegbuzie, A. J. (2004). Mixed methods research: A research paradigm whose time has come. Educational researcher, 33(7), 14-26.

Kaiser, F. G., Wölfing, S., \& Fuhrer, U. (1999). Environmental attitude and ecological behaviour. Journal of environmental psychology, 19(1), 1-19.

Kalkbrenner, B.J. \& Roosen, J. (2016). Citizens' willingness to participate in local renewable energy projects: the role of community and trust in Germany. Energy

Kayam, O., \& Hirsch, T. (2012). Using social media networks to conduct questionnaire based research in social studies case study: Family language policy. Journal of Sociological Research, 3(2), 57-67.

Keirstead, J. (2007). Behavioural responses to photovoltaic systems in the UK domestic sector. Energy Policy, 35(8), 4128-4141. doi:10.1016/j.enpol.2007.02.019 
Kelliher, F. (2011). Interpretivism and the pursuit of research legitimisation: an integrated approach to single case design. Leading issues in business research methods, 1, 45.

Kezunovic, M., Dobson, I., \& Dong, Y. (2008). Impact of extreme weather on power system blackouts and forced outages: New challenges. In 7th Balkan Power Conf.

King, M., \& Parks, M. (2012). Community Energy: Planning, development and delivery. International District Energy Association.

King, N., \& Horrocks, C. (2010). Interviews in qualitative research. Sage.

Kirk, J., \& Miller, M. L. (1986). Reliability and validity in qualitative research, 1986. Beverly Hills: Sage Publications, 41-42.

Kollmuss, A., \& Agyeman, J. (2002). Mind the gap: why do people act environmentally and what are the barriers to pro-environmental behavior?. Environmental education research, 8(3), 239-260.

Kostakis, V., \& Bauwens, M. (2014). Network society and future scenarios for a collaborative economy. Springer.

Kriegler, E., O’Neill, B. C., Hallegatte, S., Kram, T., Lempert, R. J., Moss, R. H., \& Wilbanks, T. (2012). The need for and use of socio-economic scenarios for climate change analysis: a new approach based on shared socio-economic pathways. Global Environmental

Change, 22(4), 807-822.

Kunze, C., \& Becker, S. (2015). Collective ownership in renewable energy and opportunities for sustainable degrowth. Sustainability Science, 10(3), 425-437.

Lang, T., Ammann, D., \& Girod, B. (2016). Profitability in absence of subsidies: A technoeconomic analysis of rooftop photovoltaic self-consumption in residential and commercial buildings. Renewable Energy, 87, 77-87.

Lavrakas, P. J. (2008). Encyclopedia of survey research methods Thousand Oaks, CA: Sage Publications, Inc.

Lavrijssen, S. A. C. M. (2014). The different faces of the energy consumers: Toward a behavioral economics approach. Journal of Competition Law and Economics, 10(2), 257-291. Leary, M. R. (2003). Introduction to behavioral research methods. Pearson.

Leech, N. L., Barrett, K. C., \& Morgan, G. A. (2014). IBM SPSS for intermediate statistics: Use and interpretation. Routledge.

Lindenberg, S., \& Steg, L. (2007). Normative, gain and hedonic goal frames guiding environmental behavior. Journal of Social issues, 63(1), 117-137.

Lipp, J. (2007). Lessons for effective renewable electricity policy from Denmark, Germany and the United Kingdom. Energy policy, 35(11), 5481-5495

Litwin, M. S. (1995). How to measure survey reliability and validity (Vol. 7). Sage

Loring, J. M. (2007). "Wind energy planning in England, Wales and Denmark: Factors influencing project success.” Energy Policy, Vol. 35, No. 4, pp. 2648-2660.

Lovins, A. B. (1977). Soft energy paths: Toward a durable peace.

Lund, H., \& Mathiesen, B. V. (2009). Energy system analysis of 100\% renewable energy systems - The case of Denmark in years 2030 and 2050.Energy, 34(5), 524-531.

Mabee, W. E., Mannion, J., \& Carpenter, T. (2012). Comparing the feed-in tariff incentives for renewable electricity in Ontario and Germany. Energy Policy, 40, 480-489.

Matofska, B. (2014). What is the sharing economy. The People Who Share.

Maxwell, J. A. (1992). Understanding and validity in qualitative research. Harvard educational review, 62(3), 279-301. 
May, K. A. (1991). Interview techniques in qualitative research: Concerns and challenges. Qualitative nursing research: A contemporary dialogue, 188-201.

McHarg, A. (2015). Community benefit through community ownership of renewable generation in scotland: power to the people?

Mengelkamp, E., Gärttner, J., Rock, K., Kessler, S., Orsini, L., \& Weinhardt, C. (2018).

Designing microgrid energy markets: A case study: The Brooklyn Microgrid. Applied

Energy, 210, 870-880.

Mergner, R. \& Ruth, D. (2014). Community energy in Germany: existing models, public-private funding and good practice examples. Accessed at http://www.communitypower.eu/images/GemanyD32.pdf

Merriam, S. B. (1998). Qualitative Research and Case Study Applications in Education.

Revised and Expanded from" Case Study Research in Education.". Jossey-Bass Publishers, 350 Sansome St, San Francisco, CA 94104.

Meyer, N. I. (2007). Learning from wind energy policy in the EU: lessons from Denmark, Sweden and Spain. European Environment, 17(5), 347-362.

Michelsen, C. C., \& Madlener, R. (2012). Homeowners' preferences for adopting innovative residential heating systems: a discrete choice analysis for Germany. Energy Economics, 34(5), 1271-1283.

Mignon, I. \& Bergek, A. (2016). Investments in renewable electricity production: the importance of policy revisited. Renewable Energy, 88, 307-316.

Miles, M. B. (1979). Qualitative data as an attractive nuisance: the problem of analysis. Administrative science quarterly, 590-601.

Monaghan, P. (2016). The highs and lows of community energy across Europe. Co-operative News. Accessed at http://www.thenews.coop/100890/news/co-operatives/highs-lowscommunity-energy-across-europe.

Morstyn, T., Farrell, N., Darby, S. J., \& McCulloch, M. D. (2018). Using peer-to-peer energytrading platforms to incentivize prosumers to form federated power plants. Nature

Energy, 3(2), 94.

Moss, T., Becker, S., \& Naumann, M. (2015). Whose energy transition is it, anyway?

Organisation and ownership of the energiewende in villages, cities and regions. Local

Environment, 20(12), 1547. Doi:10.1080/13549839.2014.915799

Müller, J., \& Rommel, J. (2010). Is there a future role for urban electricity cooperatives? The case of Greenpeace Energy. Can we break the addiction to fossil energy, 185-195.

Neuman, L. W. (2002). Social research methods: Qualitative and quantitative approaches.

Nolan, J.M., Schultz, P.W., Cialdini, R.B., Goldstein, N.J. \& Griskevicius, V. (2008).

Normative social influence is underdetected. Personal. Social. Psychol. Bull. 34 (7),

Nolden, C. (2013). Governing community energy_Feed-in tariffs and the development of community wind energy schemes in the United Kingdom and Germany. Energy Policy, 63, 543-552.

Ofgem. (2015). Non-Traditional Business Models: Supporting Transformational Change in the Energy Market. Accessed at https://www.ofgem.gov.uk/ofgem-publications/93586/nontraditionalbusinessmodelsdiscussionpaper-pdf

Ontario Ministry of Energy. (2016). Ontario Suspends Large Renewable Energy Procurement. Accessed at https://news.ontario.ca/mei/en/2016/09/ntario-suspends-large-renewable-energyprocurement.html

Onwuegbuzie, A. J., \& Johnson, R. B. (2006). The validity issue in mixed research. Research in the Schools, 13(1), 48-63. 
Osborne, J. W. (2015). What is rotating in exploratory factor analysis. Practical assessment, research \& evaluation, 20(2), 1-7.

Oteman, M., Wiering, M., \& Helderman, J. K. (2014). The institutional space of community initiatives for renewable energy: a comparative case study of the Netherlands, Germany and Denmark. Energy, sustainability and society, 4(1), 11.

Ottawa Renewable Energy Co-op (OREC). (2013). Recommendations to the Ontario Ministry of Energy Consultation on Making Choices: Reviewing Ontario's Long-Term Energy Plan. Owyang, J., Tran, C., \& Silva, C. (2013). The collaborative economy. Altimeter, United States. Ozaki, R. (2011). Adopting sustainable innovation: what makes consumers sign up to green electricity?. Business strategy and the environment, 20(1), 1-17.

Palm, J., \& Tengvard, M. (2011). Motives for and barriers to household adoption of smallscale production of electricity: examples from Sweden. Sustainability: Science, Practice and Policy, 7(1), 6-15.

Panteli, M., \& Mancarella, P. (2017). Modeling and evaluating the resilience of critical electrical power infrastructure to extreme weather events. IEEE Systems Journal, 11(3), 17331742.

Patton, M. Q. (2005). Qualitative research. John Wiley \& Sons, Ltd.

Porter, M. E., \& Kramer, M. R. (2011). Creating shared value. Harvard business review, 89(1/2), 62-77.

Redweik, P., Cristina Catita, and Miguel Brito. "Solar energy potential on roofs and facades in an urban landscape." Solar Energy 97 (2013): 332-341.

Reschovsky, J. D., \& Stone, S. E. (1994). Market incentives to encourage household waste recycling: Paying for what you throw away. Journal of policy analysis and management, 13(1), 120-139.

Riahi, K., Grübler, A., \& Nakicenovic, N. (2007). Scenarios of long-term socio-economic and environmental development under climate stabilization. Technological Forecasting and Social Change, 74(7), 887-935.

Riege, A. M. (2003). Validity and reliability tests in case study research: a literature review with "hands-on" applications for each research phase.Qualitative Market Research: An International Journal, 6(2), 75-86.

Rimal, R.N. (2008). Modeling the Relationship Between Descriptive Norms and Behaviors: a

Test and Extension of the Theory of Normative Social Behavior (TNSB). Health Commun. 23 (2), 103-116.

Robson C. (1993) Real World Research. A Resource for Social Scientists and PractitionerResearchers. Blackwell Publishers, Oxford.

Rogers, E.M. (1995).Diffusion of Innovations. FreePress, NewYork.

Rogers, J. C., Simmons, E. A., Convery, I., \& Weatherall, A. (2008). Public perceptions of opportunities for community-based renewable energy projects.Energy Policy, 36(11), 42174226.

Røpke, I. (2009). Theories of practice-New inspiration for ecological economic studies on consumption. Ecological Economics, 68(10), 2490-2497.

Rosa, E. A., Machlis, G. E., \& Keating, K. M. (1988). Energy and society. Annual Review of Sociology, 149-172.

Rowe, G., \& Frewer, L. J. (2005). A typology of public engagement mechanisms. Science, Technology, \& Human Values, 30(2), 251-290.

Roy, P. (2014). New economies and the energy sector. Voices of New Economies, 23. 
Roy, R., Caird, S., \& Abelman, J. (2008). YIMBY Generation-yes in my back yard! UK householders pioneering microgeneration heat.

Savan, B., Gore, C., \& Morgan, A. (2004). "Shifts in environmental governance in Canada: how are citizen environment groups to respond?" Environment and Planning, Vol. 22, No. 4, pp. 605-619.

Schell, C. (1992). The value of the case study as a research strategy.Manchester, UK:

University of Manchester, Manchester Business School, 1-15.

Schor, J. (2016). Debating the sharing economy. Journal of Self-Governance and Management Economics, 4(3), 7-22.

Schwandt, T. A. (1994). Constructivist, interpretivist approaches to human inquiry.

Seyfang, G. (2009). The new economics of sustainable consumption. Minería transnacional, narrativas del desarrollo y resistencias sociales. Buenos Aires: Biblos.

Seyfang, G., \& Haxeltine, A. (2012). Growing grassroots innovations: exploring the role of community-based initiatives in governing sustainable energy transitions. Environment and Planning-Part $C, 30(3), 381$.

Sharma, G. (2017). Pros and cons of different sampling techniques. International Journal of Applied Research, 3(7), 749-752.

Silverman, D. (Ed.). (2010). Qualitative research. Sage.

Sørensen, H. C., Larsen, J. H., Olsen, F. A., Svenson, J., \& Hansen, S. R. (2000).

Middelgrunden $40 \mathrm{MW}$ offshore wind farm, a prestudy for the Danish offshore $750 \mathrm{mw}$ wind program. In The Tenth International Offshore and Polar Engineering Conference.

International Society of Offshore and Polar Engineers.

Sovacool, B. K., \& Mukherjee, I. (2011). Conceptualizing and measuring energy security: A synthesized approach. Energy, 36(8), 5343-5355.

Soy, S. (1997). The case study as a research method. Unpublished paper, University of Texas at Austin.

Spaargaren, G., \& Van Vliet, B. (2000). Lifestyles, consumption and the environment: The ecological modernization of domestic consumption. Environmental politics, 9(1), 50-76. Statistics Canada. (2019a). Gross Domestic Product at basic prices, by industry - monthly. Accessed at https://www150.statcan.gc.ca/t1/tbl1/en/tv.action?pid=3610043402

Statistics Canada. (2019b). Internet use, by location of access by geography. Accessed at https://www150.statcan.gc.ca/t1/tbl1/en/tv.action?pid=2210005801

Statistics Canada. (2019c). Census Profile, 2016 Census: Toronto, Ontario, Canada. Accessed at https://www12.statcan.gc.ca/census-recensement/2016/dp-

$\mathrm{pd} /$ prof/details/page.cfm?Lang=E\&Geo1=CSD\&Code1=3520005\&Geo2=PR\&Code $2=01 \& D a$ $\underline{\text { ta }=\text { Count } \& \text { SearchText }=3520005 \& \text { SearchType }=\text { Begins } \& \text { SearchPR }=01 \& B 1=A 11 \& \text { Custom }=\& T}$ $\mathrm{ABID}=3$

St. Denis, G., \& Parker, P. (2009). Community energy planning in Canada: The role of renewable energy. Renewable and Sustainable Energy Reviews, 13(8), 2088-2095 Stamford, M. (2004). Community ownership: the best way forward for UK wind power (Doctoral dissertation, M. Sc. Dissertation, University of East Anglia, Norwich. Accessed at https://www.uea.ac.uk/documents/541248/10797368/Stamford+Mike.pdf/ff325ef5-cf99-465f8420-29606b7e686c 
Stiglitz, J., Sen, A., \& Fitoussi, J. P. (2009). The measurement of economic performance and social progress revisited. Reflections and overview. Commission on the Measurement of Economic Performance and Social Progress, Paris.

Stokes, K., Clarence, E., Anderson, L., \& Rinne, A. (2014). Making Sense of the UK Collaborative Economy. Nesta.

Strupeit, L., \& Palm, A. (2016). Overcoming barriers to renewable energy diffusion: business models for customer-sited solar photovoltaics in Japan, Germany and the United

States. Journal of Cleaner Production, 123, 124-136.

Sustainable Prosperity. (2010). Ontario's Feed-in Tariff for Renewable Energy: Lessons from Europe

Tashakkori, A., \& Teddlie, C. (2003). Handbook of mixed methods in social and behavioural science. Thousand Oak: CA: Sage.

Teddlie, C., \& Tashakkori, A. (2006). A general typology of research designs featuring mixed methods. Research in the Schools, 13(1), 12-28.

Teddlie, C., \& Tashakkori, A. (2009). Foundations of mixed methods research: Integrating quantitative and qualitative approaches in the social and behavioral sciences. Sage.

Thanh, N. C., \& Thanh, T. T. (2015). The interconnection between interpretivist paradigm and qualitative methods in Education. American Journal of Educational Science, 1(2), 24-27.

The Globe and the Mail. (2015). Ontario homeowners to reap solar benefits in 5 years, association says. Accessed at https://www.theglobeandmail.com/report-on-business/industrynews/energy-and-resources/ontario-homeowners-to-reap-solar-benefits-in-5-years-associationsays/article25371392/

Thomas, R. M. (2003). Blending qualitative and quantitative research methods in theses and dissertations. Corwin Press.

Thompson, B. (2007). Factor analysis. The Blackwell Encyclopedia of Sociology.

Toke, D., Breukers, S., \& Wolsink, M. (2008). Wind power deployment outcomes: How can we account for the differences? Renewable and Sustainable Energy Reviews, 12(4), 11291147.

Tyler, T.R. \& Blader, S.L. (2001). Identity and cooperative behavior in groups. Group Process. Intergroup Relat. 4(3),207-226.

UK Government. (2011). Microgeneration strategy. In: DECC (Ed.). London: Crown Copyright; 2011. Accessed at

https://assets.publishing.service.gov.uk/government/uploads/system/uploads/attachment_data/f ile/48114/2015-microgeneration-strategy.pdf

Van de Mortel, T. F. (2008). Faking it: social desirability response bias in self-report research. Australian Journal of Advanced Nursing, The, 25(4), 40.

Walker, G. (2008). What are the barriers and incentives for community-owned means of energy production and use?. Energy Policy, 36(12), 4401-4405.

Walker, G., Hunter, S., Devine-Wright, P., Evans, B., \& Fay, H. (2007). Harnessing community energies: explaining and evaluating community-based localism in renewable energy policy in the UK. Global Environmental Politics,7(2), 64-82.

Walters, R., \& Walsh, P. R. (2011). Examining the financial performance of micro-generation wind projects and the subsidy effect of feed-in tariffs for urban locations in the United Kingdom. Energy Policy, 39(9), 5167-5181. 
Walton, R. (2017). California PUC staff: Non-utility suppliers could serve $85 \%$ of load by mid-2020s. UtilityDive. Accessed at http://www.utilitydive.com/news/california-puc-staffnon-utility-suppliers-could-serve-85-of-load-by-mid-/442897/

Warren, C. R., \& McFadyen, M. (2010). Does community ownership affect public attitudes to wind energy? A case study from south-west Scotland. Land use policy, 27(2), 204-213. Willis, J. W., \& Jost, M. (2007). Foundations of qualitative research: Interpretive and critical approaches. Sage.

Willis, K., Scarpa, R., Gilroy, R., \& Hamza, N. (2011). Renewable energy adoption in an ageing population: Heterogeneity in preferences for micro-generation technology adoption. Energy Policy, 39(10), 6021-6029.

Wizelius, T. (2014). Windpower Ownership in Sweden: Business Models and Motives.

Routledge.

Yates, B., \& Horvath, C. (2013). Social license to operate: How to get it, and how to keep it. Pacific Energy Summit, 2013.

Yildiz, Ö. (2014). Financing renewable energy infrastructures via financial citizen participation - the case of Germany. Renewable Energy, 68, 677-685.

Yin, R. (2013). Case study research: Design and methods. Beverly Hills, CA: Sage

Publishing. 